\author{
UNIVERSIDADE DE SÃO PAULO \\ Faculdade de Ciências Farmacêuticas \\ Departamento de Tecnologia Bioquímico-Farmacêutica \\ Área de Tecnologia de Alimentos
}

\title{
SÍNTESE DE LIPÍDIOS ESTRUTURADOS POR INTERESTERIFICAÇÃO DE BANHA E ÓLEO DE SOJA PARA OBTENÇÃO DE SUCEDÂNEO DA GORDURA DO LEITE HUMANO
}

Roberta Claro da Silva

Tese para obtenção do grau de DOUTOR Orientador: Prof. Dr. Luiz Antonio Gioielli

São Paulo

2008 


\section{Roberta Claro da Silva}

SÍNTESE DE LIPÍDIOS ESTRUTURADOS POR INTERESTERIFICAÇÃO DE BANHA E ÓLEO DE SOJA PARA OBTENÇÃO DE SUCEDÂNEO DA GORDURA DO LEITE HUMANO

Comissão Julgadora

da

Tese de obtenção do grau de Doutor

Prof. Dr. Luiz Antonio Gioielli

Orientador /Presidente

$1^{\circ}$. examinador

$2^{\circ}$. examinador

$3^{\circ}$. examinador

4ํ. Examinador

São Paulo, ,de 


\section{DEDICATÓRIA}

Ao meu marido, Flávio Garcia de Mello

Por todo seu amor, compreensão e apoio. 


\section{AGRADECIMENTOS}

Ao meu orientador, Prof. Luiz Antonio Gioielli, pelo exemplo de profissionalismo, pela confiança em meus esforços, pelo apoio, e orientação segura durante todo o curso de doutorado.

Ao Prof. Dr. Victor Manuel Balcão, pelo estágio em seu laboratório na Universidade Fernando Pessoa, Porto, Portugal, e a todos os profissionais que me acompanharam nesse período em especial aos técnicos Pedro, Miguel e João.

A todos os amigos durante a estada em Portugal, Raquel, Thirzá, Andréia, Thais, Juliana, Fabinho, Flávia e Clarice.

À Doutora Virgínia Quintal e todas as funcionárias do Banco de Leite do Hospital Universitário que forneceram amostras de leite humano e nos auxiliaram em todas as dúvidas.

Ao Prof. Dr. José Alfredo Gomes Arêas e a Faculdade de Saúde Pública, por ceder o uso do equipamento de Ressonância Magnética Nuclear.

Aos estagiários Lucia, Tatyane, Daniela, Maíra e Jonas, que me ajudaram a aprender a ensinar e orientar.

A todos os meus colegas de trabalho, Cínthia, Juliana, Flávia, Keila, Lucas, Haíssa, Marissol, Regina, Ricardo, Eli, Joyce, Carol, Michele, Camila, Virgílio e Juliana Ract, entre tantos outros pela ajuda e convivência diária.

Aos funcionários Alexandre, Nilton, Ivani, Fátima, Juarez, Elza, Míriam e aos professores Suzana Lannes, Susana Saad, Maricê e Pitombo, pela contribuição pelo meu crescimento científico e intelectual.

Às empresas Novozymes, Loaders \& Croaklan pelas doações para esta pesquisa.

A Faculdade de Ciências Farmacêuticas, pela oportunidade de realização do curso de doutorado.

À Coordenação de Aperfeiçoamento de Pessoal de Nível Superior, pela concessão de bolsa de doutorado e ao Conselho Nacional de Desenvolvimento Científico e Tecnológico e a Fundação de Amparo à Pesquisa do Estado de São Paulo, pelo apoio financeiro para a realização desta pesquisa.

Aos meus pais, Carlos e Margarida pela compreensão e primordial apoio.

$\mathrm{E}$ a todos os que não foram citados, mas que estão cientes de sua participação direta ou indireta na realização deste trabalho. 


\section{RESUMO}

SILVA, R. C. Síntese de lipídios estruturados por interesterificação de banha e óleo de soja para obtenção de sucedâneo da gordura do leite humano. 165 p. Tese (Doutorado) - Faculdade de Ciências Farmacêuticas, Universidade de São Paulo, 2008.

O leite humano é um alimento completo, possui todos os nutrientes em quantidade e qualidade necessárias, proporciona proteção contra infecções e alergias e estimula o sistema imunológico. Os lipídios do leite humano são fonte energética; veículos para as vitaminas lipossolúveis; contêm ácidos graxos poliinsaturados necessários para o desenvolvimento cerebral; contêm precursores de prostaglandinas e hormônios; e são constituintes essenciais para as membranas celulares. Muitas mães, por razões médicas, metabólicas ou econômicas, dependem de fórmulas artificiais para alimentar seus filhos. Portanto, a composição dos ácidos graxos e a sua distribuição nas cadeias dos triacilgliceróis devem ser alvos de estudos em fórmulas infantis, sendo que os triacilgliceróis do leite humano devem servir de modelo para os componentes lipídicos. Recentemente, diversos estudos apontam a interesterificação como alternativa para a produção de sucedâneos da gordura do leite humano. Assim, o objetivo deste trabalho foi explorar diversas possibilidades da modificação lipídica para a obtenção deste sucedâneo. As matérias-primas utilizadas foram banha e óleo de soja, gorduras facilmente obtidas e de baixo custo no Brasil. Neste trabalho, foram produzidos lipídios estruturados por interesterificação química e enzimática, sendo que na interesterificação enzimática foram utilizadas duas lipases puras, a AY30 ${ }^{\text {TM }}$ (Candida cylindracea) e a M10 TM (Mucor circinelloides), e a lipase imobilizada Lipozyme TL IM (Thermomices lanuginosa). Os lipídios estruturados foram submetidos a análises de suas propriedades químicas e físicas, que foram comparadas às propriedades da gordura do leite humano e do lipídio estruturado comercial Betapol ${ }^{\mathrm{TM}}$. Os resultados apresentados demonstraram a viabilidade da interesterificação como método de modificação para obtenção de lipídios estruturados sucedâneos da gordura do leite humano. Tendo em vista a possibilidade de maior controle reacional devido à especificidade das lipases e a busca por processos ambientalmente corretos, a interesterificação enzimática mostra-se alternativa mais interessante para esta modificação lipídica. A mistura de banha e óleo de soja demonstrou ser opção viável para a produção de sucedâneos da gordura do leite humano.

Palavras-chave: lipídios estruturados, gordura do leite humano, banha, óleo de soja, interesterificação, propriedades físicas 


\begin{abstract}
Human milk is a complete food with all the nutrients in quantity and quality provides protection against infections and allergies and stimulates the immune system. The lipids of human milk are source of energy; vehicles for liposoluble vitamins; contain polyunsaturated fatty acids for brain development; contain precursors of prostaglandins, hormones; and are essential constituents to the cell membranes. Many mothers, for medical, metabolic or economic reasons, depend on artificial formulas to feed their children. Therefore, the composition of fatty acids and their distribution chains in the triacylglycerols must be targets of studies on infant formula, and the human milk triacylglycerols should be a model for the lipid components. Recently, several studies indicate the interesterification like an alternative for the production of substitutes of human milk fat. The objective of this study was to explore various possibilities of lipid modification to achieve this substitute. The raw materials used were lard and soybean oil, fats easily obtained and cheap in Brazil. In this work, were produced structured lipids by chemical and enzymatic interesterification. For enzymatic interesterification were used two pure lipases, AY30 TM (Candida cylindracea) and M10 TM (Mucor circinelloides) and one immobilized lipase, Lipozyme TL IM (Thermomices lanuginosa). The structured lipids were submitted to analysis of their chemical and physical properties, which were compared with the human milk fat and the structured commercial lipid Betapol TM. The results demonstrated the feasibility of interesterification as a method of modification to obtain structured lipids substitutes of human milk fat. The possibility of greater control reaction because the specificity of lipases and the search for environmentally correct procedures makes enzymatic interesterification the most attractive alternative for modifying lipids. The mixture of soybean oil and lard is a viable alternative for the production of human milk fat substitutes.
\end{abstract}

Keywords: structured lipids, human milk, lard, soybean oil, interesterification, physical properties 


\section{SUMÁRIO}

1. LIPÍDIOS ESTRUTURADOS: ALTERNATIVA PARA A PRODUÇÃO DE SUCEDÂNEOS DA GORDURA DO LEITE HUMANO

1.1 LEITE HUMANO

1.2 GORDURA DO LEITE HUMANO 06

1.3 MODIFICAÇÃO DE LIPÍDIOS 10

1.4 INTERESTERIFICAÇÃO QUÍMICA 11

1.5 INTERESTERIFICAÇÃO ENZIMÁTICA 11

1.6 LIPÍDIOS ESTRUTURADOS - SUCEDÂNEOS DA GORDURA DO LEITE HUMANO

1.7 CONCLUSÕES

1.8 REFERÊNCIAS BIBLIOGRÁFICAS

2. COMPOSIÇÃO CENTESIMAL DO LEITE HUMANO E CARACTERIZAÇÃO DAS PROPRIEDADES FISICO-QUÍMICAS DE SUA GORDURA E DE SUCEDÂNEO 
2.2 MATERIAL E MÉTODOS

38

2.2.1 Amostras 38

2.2.2 Métodos 38

2.3 RESULTADOS DE DISCUSSÃO 40

2.3.1 Composição Centesimal 40

2.3.2 Propriedades físico-químicas da gordura do leite humano e do Betapol_ 42

2.4 CONCLUSÕES 48

2.5 REFERÊNCIAS BIBLIOGRÁFICAS 49

3 PROPRIEDADES FÍSICAS DAS MISTURAS E DOS LIPÍDIOS ESTRUTURADOS OBTIDOS A PARTIR DA BANHA E ÓLEO DE SOJA POR INTERESTERIFICAÇÃO QUÍMICA

3.1 INTRODUÇÃO 55

3.2 MATERIAL E MÉTODOS 58

3.2.1 Matéria Prima 58

3.2.2 Mistura 59

3.2.3 Interesterificação química 59

3.2.4 Conteúdo de gordura sólida 60

3.2.5 Consistência 60 
3.2.6 Preparação dos ésteres metílicos de ácidos graxos 61

3.2.7 Composição em ácidos graxos 61

3.2.8 Composição em triacilgliceróis 62

3.2.9 Ponto de fusão 62

3.3 RESULTADOS E DISCUSSÃO 63

3.3.1 Composição em ácidos graxos 63

3.3.2 Composição em triacilgliceróis 65

3.3.3 Ponto de fusão 67

3.3.4 Conteúdo de gordura sólida 68

3.3.5 Consistência 73

3.4 CONCLUSÕES 78

3.5 REFERÊNCIAS BIBLIOGRÁFICAS 79

4. COMPORTAMENTO DE CRISTALIZAÇÃO DE LIPÍDIOS ESTRUTURADOS POR INTERESTERIFICAÇÃO QUÍMICA DE BANHA E ÓLEO DE SOJA

4.1 INTRODUÇÃO 85

4.2 MATERIAL E MÉTODOS 90

4.2.1 Interesterificação química 90

4.2.2 Microscopia sob luz polarizada 90

4.2.3 Cinética de cristalização 90 
4.3 RESULTADOS E DISCUSSÃO

93

4.4 CONCLUSÕES 104

4.5 REFERÊNCIAS BIBLIOGRÁFICAS 105

5. PROPRIEDADES FÍSICAS DAS MISTURAS E DOS LIPÍDIOS ESTRUTURADOS OBTIDOS A PARTIR DA BANHA E ÓLEO DE SOJA POR INTERESTERIFICAÇÃO ENZIMÁTICA 108

5.1 INTRODUÇÃO

5.2 MATERIAIS E MÉTODOS

5.2.1 Material

5.2.2 Métodos 113

5.2.2.1 Mistura 113

5.2.2.2 Reação de interesterificação 113

5.2.2.3 Composição em ácidos graxos 114

5.2.2.4 Índice de lodo 114

5.2.2.5 Ponto de amolecimento 114

5.2.2.6 Consistência 114

5.2.2.7 Conteúdo de gordura sólida 116

5.2.2.8 Análise estatística 116

5.3 RESULTADOS E DISCUSSÃO 
5.3.2 Índice de lodo 120

5.3.3 Ponto de amolecimento 120

5.3.4 Consistência 121

5.3.5 Conteúdo de gordura sólida 124

5.3.6 Análise estatística 127

5.4 CONCLUSÃO 128

5.5 REFERÊNCIAS BIBLIOGRÁFICAS 129

6. INTERESTERIFICAÇÃO ENZIMÁTICA DE BANHA E ÓLEO DE SOJA PARA A PRODUÇÃo DE SUCEDÂNEO DA GORDURA DO LEITE HUMANO

6.1 INTRODUÇÃO

6.2 MATERIAIS E MÉTODOS

6.2.1 Material

6.2.2 Métodos 138

6.2.2.1 Misturas 138

6.2.2.2 Reação de interesterificação 138

6.2.2.3 Composição em ácidos graxos 138

6.2.2.4 Ponto de amolecimento 139

6.2.2.5 Consistência 139

6.2.2.6 Microscopia 140 
6.2.2.7 Conteúdo de gordura sólida

6.2.2.8 Composição em triacilgliceróis 141

6.2.2.9 Análise estatística 141

6.3 RESULTADOS E DISCUSSÃO 142

6.3.1 Composição em ácidos graxos 142

6.3.2 Composição em triacilgliceróis 144

6.3.3 Ponto de Amolecimento 148

6.3.4 Consistência 149

6.3.5 Conteúdo de gordura sólida 150

6.3.6 Microscopia 151

6.3.7 Análise estatística 154

6.4 CONCLUSÕES 155

6.5 REFERÊNCIAS BIBLIOGRÁFICAS 156 CONSIDERAÇÕES FINAIS 162 ANEXOS 163 


\section{LISTA DE TABELAS}

Tabela 1. Composição dos leites humano e bovino 5

Tabela 2. Distribuição dos principais ácidos graxos no leite humano 9

Tabela 3. Composição centesimal média de colostro e leite humano maduro_ 40

Tabela 4. Média dos valores energéticos estimados pelo crematócrito e calculados pela composição centesimal

Tabela 5. Composição em ácidos graxos, acidez e índice de iodo do Betapo $^{\mathrm{TM}}$ e da gordura do leite humano

Tabela 6. Diâmetro médio e número dos cristais da gordura do leite humano e do BetapolTM

Tabela 7. Planejamento experimental das misturas 59

Tabela 8. Composição em ácidos graxos e índice de iodo da banha, do óleo de soja e suas misturas antes da interesterificação_

Tabela 9. Composição em ácidos graxos e índice de iodo da banha, do óleo de soja e suas misturas após a interesterificação

Tabela 10. Composição em triacilgliceróis da banha e suas misturas binárias com o óleo de soja antes e após a interesterificação química 66

Tabela 11. Pontos de fusão da banha, do óleo de soja e de suas misturas binárias antes e após a interesterificação química 
Tabela 12. Coeficientes calculados por regressão múltipla a partir dos resultados experimentais do conteúdo de gordura sólida antes da interesterificação química

Tabela 13. Coeficientes calculados por regressão múltipla a partir dos resultados experimentais do conteúdo de gordura sólida após a interesterificação química

Tabela 14. Coeficientes calculados por regressão múltipla a partir dos resultados experimentais de consistência antes da interesterificação

Tabela 15. Coeficientes calculados por regressão múltipla a partir dos resultados de consistência após a interesterificação

Tabela 16. Coeficientes de regressão linear simples e coeficiente de determinação para conteúdo de gordura sólida e consistência antes da interesterificação

Tabela 17. Coeficientes de regressão linear simples e coeficiente de determinação para conteúdo de gordura sólida e consistência após a interesterificação

Tabela 18. Constante de Avrami (k), expoente de Avrami (n) e coeficiente de determinação $\left(R^{2}\right)$ das misturas de banha e óleo de soja antes e após a interesterificação 
Tabela 19. Diâmetro médio dos cristais das misturas de banha e óleo de soja antes e após a interesterificação química

Tabela 20. Número de cristais das misturas de banha e óleo de soja antes e após a interesterificação química

Tabela 21. Dimensão fractal dos cristais das misturas de banha e óleo de soja antes e após a interesterificação

Tabela 22. Composição em ácidos graxos da banha, óleo de soja e suas misturas binárias antes e após a interesterificação

Tabela 23. Composição em ácidos graxos da banha, óleo de soja e de suas misturas binárias antes e após a interesterificação

Tabela 24. Composição em triacilgliceróis da banha, óleo de soja e suas mistura binárias antes e após a interesterificação $(\mathrm{P}$, ácido palmítico; $\mathrm{Po}$, ácido palmitoléico $\mathrm{M}$, ácido mirístico; St, ácido esteárico; $\mathrm{O}$, ácido oléico; L,ácido linoléico; Ln, ácido linolênico)

Tabela 25. Ponto de amolecimento da banha e de suas misturas binárias com o óleo de soja antes e após a interesterificação enzimática 



\section{LISTA DE FIGURAS}

Figura 1. Estrutura do principal triacilglicerol do Betapol

Figura 2. Esquema de produção do Betapol

Figura 3. Consistência do Betapol e da gordura do leite humano

Figura 4. Conteúdo de gordura sólida do Betapol e da gordura do leite humano

Figura 5. Estrutura cristalina da gordura do leite humano e do Betapol ${ }^{\mathrm{TM}}$. A barra representa $250 \mu \mathrm{m}$

Figura 6. Correlação entre o ponto de fusão e a composição em triacilgliceróis di e trissaturados das gorduras

Figura 7. Conteúdo de gordura sólida da banha, do óleo de soja e das misturas binárias antes da interesterificação

Figura 8. Conteúdo de gordura sólida da banha, do óleo de soja e das misturas binárias após a interesterificação química

Figura 9. Correlação entre o percentual de ácido esteárico e o conteúdo de gordura sólida a $20^{\circ} \mathrm{C}$

Figura 10. Correlação entre o percentual de ácido linoléico e o conteúdo de gordura sólida a $20^{\circ} \mathrm{C}$

Figura 11. Consistência da banha, do óleo de soja e das misturas binárias antes da interesterificação

Figura 12. Consistência da banha, do óleo de soja e das misturas binárias após a interesterificação

Figura 13. Cinética de cristalização a $10^{\circ} \mathrm{C}$ da banha antes e após a interesterificação 
Figura 14. Cinética de cristalização a $10^{\circ} \mathrm{C}$ da mistura de banha com $20 \%$ de óleo de soja antes e após a interesterificação

Figura 15. Cinética de cristalização a $10^{\circ} \mathrm{C}$ da mistura de banha com $40 \%$ de óleo de soja antes e após a interesterificação

Figura 16. Imagens da cristalização da banha antes e após a interesterificação química. A barra representa $200 \mu \mathrm{m}$

Figura 17. Imagens da cristalização da mistura de $80 \%$ de banha com $20 \%$ de óleo de soja antes e após a interesterificação química. A barra representa 200 $\mu \mathrm{m}$

Figura 18. Imagens da cristalização da mistura de $60 \%$ de banha com $40 \%$ de óleo de soja antes e após a interesterificação química. A barra representa 200 $\mu \mathrm{m}$

Figura 19. Ponto de amolecimentos da banha, suas misturas binárias antes e após a interesterificação

Figura 20. Consistência da banha antes e após a interesterificação

Figura 21. Consistência da mistura contendo $80 \%$ banha $+20 \%$ óleo de soja antes e após a interesterificação

Figura 22. Consistência da mistura contendo $60 \%$ banha $+40 \%$ óleo de soja antes e após a interesterificação

Figura 23. Consistência da mistura contendo $50 \%$ banha $+50 \%$ óleo de soja antes e após a interesterificação

Figura 24. Conteúdo de gordura sólida da banha antes e após a interesterificação 
Lista de Figuras IX

Figura 25. Conteúdo de gordura sólida da mistura contendo $80 \%$ banha +20 \% óleo de soja antes e após a interesterificação 125

Figura 26. Conteúdo de gordura sólida da mistura contendo $60 \%$ banha +40 \% óleo de soja antes e após a interesterificação

Figura 27. Conteúdo de gordura sólida da mistura contendo $50 \%$ banha +50 \% óleo de soja antes e após a interesterificação

Figura 28. Perfil de TAGs da banha e suas misturas com o óleo de soja antes e após a interesterificação (Abreviações:SSS, trisaturados; SSI disaturados; IIS, monosaturados e III, triinsaturados)

Figura 29. Consistência da banha e de suas misturas binárias com o óleo de soja antes e após a interesterificação enzimática com a Lipozyme

Figura 30. Conteúdo de gordura sólida da banha e suas misturas binárias com o óleo de soja antes e após a interesterificação enzimática

Figura 31. Área cristalizada da banha e de suas misturas binárias com o óleo de soja antes e após a interesterificação enzimática

Figura 32. Imagens digitalizadas da rede cristalina a $15^{\circ} \mathrm{C}$. A barra branca representa $250 \mu \mathrm{m}$ 



\section{Lipídios estruturados: alternativa para a}

produção de sucedâneos da gordura do leite humano

SILVA, R.C.; GIOIELLI, L.A. Lipídios estruturados: alternativa para a produção de sucedâneos da gordura do leite humano. Enviado para publicação na revista Química

Nova

em

$21 / 12 / 2007$ 


\section{RESUMO}

O leite humano possui características de grande importância para o recém-nascido, uma vez que sua composição apresenta todos os nutrientes em quantidade e qualidade necessárias, além de proporcionar proteção contra infecções e alergias e estimular o sistema imunológico. Os lipídios do leite humano são essenciais para o desenvolvimento de recém-nascidos, por vários motivos: são fonte energética; são veículos para as vitaminas lipossolúveis; contêm ácidos graxos poliinsaturados necessários para o desenvolvimento cerebral; contêm precursores de prostaglandinas e hormônios; são constituintes essenciais para as membranas celulares. Muitas mães, por razões médicas, metabólicas ou econômicas, dependem de fórmulas artificiais para alimentar seus filhos. Portanto, a composição dos ácidos graxos e a sua distribuição nas cadeias dos triacilgliceróis devem ser alvos de estudos em fórmulas infantis, sendo que os triacilgliceróis do leite humano devem servir de modelo para os componentes lipídicos. Estudos indicam como melhor alternativa o desenvolvimento de lipídios estruturados com características estereoespecíficas semelhantes à gordura do leite humano. Esta revisão visa reportar estudos realizados em tecnologia de lipídios com o intuito de produzir lipídios estruturados sucedâneos da gordura do leite humano. 


\subsection{LEITE HUMANO}

Sob os pontos de vista nutricional, imunológico e de segurança, o leite humano é considerado o melhor alimento para crianças na primeira fase de sua vida (MEGRAUD et al., 1990). O leite humano mantém o crescimento e desenvolvimento normais, melhora o processo gastrointestinal, favorece o vínculo mãe-filho (ANVISA, 2007) e facilita os desenvolvimentos emocional, cognitivo e do sistema nervoso (ANDERSON et al., 1999; BEZKOROVAINY, 2001; CALHOUN et al., 2001).

O leite materno é um líquido rico em gordura, minerais, vitaminas, enzimas e imunoglobolinas que protegem contra doenças. Apesar do leite maduro ser formado em $87 \%$ por água, os restantes $13 \%$ são uma poderosa combinação de elementos, fundamentais para o crescimento e desenvolvimento da criança.

A secreção láctea apresenta as seguintes fases : a) Colostro: é a secreção apresentada até 5 dias após o parto, contém o mais alto teor de proteínas, principalmente imunoglobulinas e lactoferrina. Seu conteúdo de gordura $(2 \%)$ é inferior ao do leite maduro (3,5\%); b) Leite transicional: é a secreção entre o 6 e 0 15ำ dia após o parto. A imunoglobulina diminui, enquanto a lactose, gordura e vitaminas hidrossolúveis aumentam. É a fase mais variável entre as lactantes; c) Leite maduro: é produzido após o 15ำ dia de lactação e, comparado ao colostro é uma secreção mais fina e aquosa. O leite inicial da mamada é mais fino e aquoso, pois, tem a função de suprir a sede e as necessidades líquidas do bebê, enquanto o leite do final da mamada tem quatro vezes mais gordura que o leite inicial, com a função de fornecer calorias ao lactente (PONS et al., 2000).

As proteínas do leite humano são estrutural e qualitativamente diferentes das do leite bovino. Do conteúdo protéico do leite humano, $80 \%$ são constituídos pela lactoalbumina, enquanto que no leite de vaca a caseína corresponde a aproximadamente $80 \%$. Desse modo, a relação proteínas do soro/caseína do leite humano é aproximadamente $80 / 20$, enquanto a do leite bovino é $20 / 80$. A baixa concentração de caseína no leite humano resulta na formação de coalho gástrico mais leve, com flóculos de mais fácil digestão e com reduzido tempo de esvaziamento gástrico (SILVA et al., 2007).

O leite humano contém, também, diferentemente do leite de vaca, maiores concentrações de aminoácidos essenciais de alto valor biológico (cistina e taurina) que são fundamentais para o crescimento do sistema nervoso central. Isso é 
particularmente importante para o prematuro, que não consegue sintetizá-los a partir de outros aminoácidos por deficiência enzimática (SILVA et al., 2007).

O principal carboidrato no leite humano é a lactose, sendo que mais de 30 açúcares já foram identificados, como a galactose, frutose e outros oligossacarídeos. A concentração de lactose é de $4 \%$ no colostro e de até $7 \%$ no leite maduro. A lactose facilita a absorção de cálcio e ferro e promove a colonização intestinal com Lactobacillus bifidus.

Em relação à gordura, a principal diferença entre os leites bovino e humano está na quantidade dos ácidos graxos saturados presentes na posição sn-2 dos triacilgliceróis. No leite bovino, os ácidos palmítico e esteárico estão igualmente distribuídos entre as posições sn-1,3 (34\% e 10\%) e sn-2 (32\% e 10\%). O leite humano tem mais ácido palmítico (58\%) e menos ácido esteárico (3\%) na posição sn-2, em contraste com suas quantidades nas posições $s n-1,3(16 \%$ e $15 \%$, respectivamente) (KARUPAIAH \& SUNDRAM, 2007).

A composição do leite humano foi descrita e comparada ao leite bovino por PRENTICE (2002), conforme apresentado na Tabela 1. 
Tabela 1. Composição dos leites humano e bovino.

$\begin{array}{lll}\text { Composição } & \text { Leite humano Leite bovino }\end{array}$

\section{Gorduras}

Total $(\mathrm{g} / 100 \mathrm{~mL})$

4,2

3,8

Ácidos graxos de até 8 carbonos

6

$(\%)$

Ácidos graxos poliinsaturados

14

3

(\%)

Proteínas $(\mathrm{g} / 100 \mathrm{~mL})$

Total

caseína

1,1

3,3

$\alpha$-lactoalbumina

0,3

2,5

lactoferrina

0,3

0,1

$\lg A$

0,2

$\lg G$

0,1

0,003

0,001

0,06

lisozima

0,05

albumina sérica

0,05

0,03

B-lactoglobulina

- $\quad 0,3$

Carboidratos (g/100 mL)

lactose

oligossacarídeos

Minerais (g/100 $\mathrm{mL}$ )
7,0

0,5
4,8

0,005

cálcio 0,030

0,125

fósforo

0,014

0,093

sódio

0,015

0,047

potássio

0,055

0,155

PRENTICE, 2002 
No Brasil existe, desde 1998, a Rede Nacional de Bancos de Leite Humano, coordenada pela FIOCRUZ (FUNDAÇÃO INSTITUTO OSWALDO CRUZ) e o Programa Nacional de Incentivo ao Aleitamento Materno, onde estão cadastradas 187 unidades de bancos de leite. Com a criação da Rede Nacional de Bancos de Leite Humano foram desenvolvidas novas metodologias de controle de qualidade tipicamente adaptadas às necessidades nacionais, seguras e sensíveis o suficiente para serem praticadas na rotina. A qualidade dos produtos processados, estocados e distribuídos pelos Bancos de Leite deve ser fruto de esforço racional e constante em todas as etapas. A qualidade do leite humano ordenhado pode ser definida como elemento que resulta da avaliação conjunta de uma série de parâmetros, que incluem as características nutricionais, imunológicas, químicas e microbiológicas. $\mathrm{O}$ critério para avaliar a qualidade é complexo e incorpora os planos de amostragem, os métodos de análise e os padrões de qualidade. Os padrões devem ser dinâmicos e ajustados à evolução técnica do setor, resultando em produtos cada vez melhores. Além das análises microbiológicas são avaliados a acidez Dornic e o teor de gordura como controle físico-químico do produto (REDE NACIONAL DE BANCOS DE LEITE HUMANO, 2007).

Apesar de todos os esforços em estimular o aleitamento materno, a urbanização e a falta de tempo reduziram o período de amamentação. Além disso, alguns recém-nascidos não são amamentados devido à baixa produção de leite, estado nutricional e condição de saúde desfavorável da lactante, ou até em função da morte da mãe durante ou após o parto. Conseqüentemente, existe a necessidade de fornecer meios alternativos de alimentação para aqueles recém-nascidos que não podem ser amamentados. Como a demanda por alternativas ao leite humano é contínua, um substituto para o leite humano deve ser tão próximo quanto possível do original, para atender as exigências nutritivas do crescimento infantil e substituir o leite materno nestes casos. Este substituto deve estar o mais próximo possível das características do leite humano quantitativa e qualitativamente (MADUKO et al., 2007)

\subsection{GORDURA DO LEITE HUMANO}

O leite humano contém de 3 a $5 \%$ de lipídios, dentre os quais $98 \%$ são compostos por triacilgliceróis (CHANG et al., 1990; YANG et al., 2003 ${ }^{\mathrm{a}}$ ), 1,3\% de fosfolipídios e 0,4\% de colesterol (JENSEN, 1996; JENSEN, 1988; JENSEN et al., 
1990). Os ácidos graxos representam 90\% dos triacilgliceróis e $88 \%$ dos lipídios totais (JENSEN, 2001). A gordura do leite humano é a principal fonte de energia para o recém-nascido (aproximadamente 50\% das calorias totais), é fonte de ácidos graxos essenciais, como os ácidos linoléico (C18:2 n-6) e alfa-linolênico (C18:3 n3), e participa do transporte de vitaminas ( $A, D, E$ e $K$ ) e hormônios lipossolúveis (JENSEN et al., 1978; JENSEN et al., 1990; LONNERDAL, 1986).

O teor de lipídios varia de acordo com o tempo de duração da lactação (DEWEY et al., 1984; JENSEN 1989), ao longo do período do dia (HALL, 1979; HARZER et al., 1983; JENSEN, 1989) e do leite de início ou fim da amamentação (KOLETZKO et al., 1992). A concentração dos triacilgliceróis aumenta de aproximadamente 30 $\mathrm{g} / \mathrm{L}$ no colostro para $35 \mathrm{~g} / \mathrm{L}$ no leite transicional e $40 \mathrm{~g} / \mathrm{L}$ no leite maduro (JENSEN, 1999; SMIT et al., 2002).

Os ácidos graxos são em sua maioria de cadeia longa, com cerca de $50 \%$ de saturados e 50\% de insaturados. O ácido palmítico consiste na maior proporção (53-70\%) dos ácidos graxos saturados (JENSEN, 1989; INNIS et al., 1995; XU, 2000). Mais de 200 ácidos graxos já foram identificados no leite humano, sendo que apenas sete correspondem a cerca de $90 \%$ do total da gordura (VAN BEUSEKOM et al., 1993), representados pelos ácidos oléico, palmítico, láurico, linoléico, mirístico, esteárico e cáprico. Os ácidos graxos de cadeia média (C6 - C12) representam apenas cerca de $7 \%$.

A composição em ácidos graxos da gordura do leite humano varia de acordo com alguns fatores, como: dieta, estágio de lactação, estação do ano e condições individuais da lactante (CHRISTIE, 1995; JENSEN, 1998; CLARK \& HUNDRIESER, 1993).

A gordura se apresenta na forma de glóbulos de cerca de $4 \mu \mathrm{m}$ de diâmetro em emulsão de óleo em água, estabilizada por uma membrana contendo fosfolipídios e proteínas (CHRISTIE, 1982; MICHALSKI et al., 2005).

Valores médios para os teores de gordura do leite humano, incluindo os ácidos graxos, estão disponíveis nos dados de nutrição do UNITED STATES DEPARTAMENT OF AGRICULTURE (USDA, 2002). AGOSTONI et al. (2001) estudaram o conteúdo de gordura total e os ácidos graxos no colostro e ao longo de 12 meses de lactação, o total de ácidos graxos poliinsaturados (PUFAs), as concentrações de ácido araquidônico (AA - 20:4 n-6) e de ácido docosahexaenóico 
(DHA - 22:6 n-3), que permaneceram estáveis do colostro até os 12 meses de lactação.

A dieta de gorduras nos primeiros anos de vida tem sido extensivamente investigada devido às associações ao desenvolvimento cerebral (AGOSTONI, 2003).

Os ácidos graxos no leite humano tem distribuição posicional muito específica nas moléculas dos triacilgliceróis, e esta configuração específica tem sido sugerida como a principal causa da eficiência da absorção do leite humano (LIEN, 1994; FILER et al., 1969; TOMARELLI et al., 1968; JENSEN, 1989; CARLSON et al., 1986). Embora o leite humano contenha pelo menos 170 diferentes estruturas de triacilgliceróis, apenas 30 delas representam $70 \%$ do total da gordura. A estrutura dos triacilgliceróis do leite humano que mais favorece a hidrólise pelo recémnascido é aquela formada por ácidos graxos insaturados esterificados na posição $s n-1$, ácidos saturados na posição $s n-2$ e os de ácidos de cadeia média na posição sn-3 (WINTER et al., 1993).

O ácido palmítico (16:0) é o ácido graxo saturado predominante, constituindo 20$25 \%$ dos ácidos graxos do leite maduro, sendo $70-75 \%$ esterificado na posição $s n-2$ dos triacilgliceróis (BRECKENRIDGE et al.,1969; INNIS et al., 1995; XU et al., 2000; SAHIN et al., 2005). Em contrapartida, o ácido palmítico presente nos óleos vegetais, largamente utilizados para a produção de fórmulas infantis, são esterificados predominantemente nas posições sn-1 e sn-3 (LIEN et al., 1994), sendo que a posição sn-2 é principalmente ocupada pelos ácidos graxos insaturados (SMALL, 1991; INNIS et al., 1994). A explicação para a esterificação preferencial do ácido palmítico na posição $s n-2$ nos triacilgliceróis do leite humano durante a síntese na glândula mamária ainda é incerta. Entretanto, sabe-se que a lipase pancreática hidrolisa seletivamente os ácidos graxos das posições sn-1 e sn3, produzindo ácidos graxos livres e 2-monoacilgliceróis, sendo que o 2-palmitoilglicerol é melhor absorvido que o ácido palmítico na sua forma livre, que tende a formar no $\mathrm{pH}$ alcalino do intestino delgado sabões insolúveis com cátions como o cálcio e o magnésio (CHAPPELL et al., 1986; DE FOUW et al., 1994; FILER et al., 1969; JENSEN et al., 1986; MATTSON \& VOLPENHEIM, 1964; TANTIBHEDHYANGKUL \& HASHIM, 1979; CARRIERE et al., 1993; SMALL, 1991; QUINLAN et al., 1995; INNIS et al., 1994; FORSYNTH, 1998). Os ácidos graxos de cadeia curta e os de 18 carbonos, como o oléico e o linoléico, são bem absorvidos 
na forma de ácidos graxos livres (DE FOUW et al., 1994; FILER et al., 1969; JENSEN et al., 1986; CARNIELLI et al., 1996; KENNEDY et al., 1999). A combinação de ácidos graxos que formam os triacilgliceróis do leite humano mantém o ponto de fusão abaixo dos 38 C (JENSEN, 1999; SILVA et al., 2007), ao passo que o ponto de fusão do ácido palmítico na forma livre é de 61-65 ํㅡ (GUNSTONE, 1999), sendo muito superior ao da temperatura corporal e explicando sua baixa absorção na forma livre (JENSEN, et al.1986; CARNIELLI et al., 1996).

Desta forma, com a presença preponderante do ácido palmítico na posição sn-2, há melhor aproveitamento pelo recém-nascido da energia proveniente dos ácidos graxos constituintes do leite materno, bem como se minimiza a perda de cálcio pelas fezes caso o ácido palmítico não fosse eficientemente absorvido, mas sim eliminado na forma de palmitato de cálcio (DUBOIS et al., 2007; MU \& PORGAARD, 2005; OSBORN \& AKOH, 2002; KARUPAIAH \& SUNDRAM, 2007). Ao contrário das crianças, os adultos aparentemente têm maior eficiência de absorção, independentemente da distribuição estereoespecífica dos ácidos graxos, mas os estudos que comprovam este ponto de vista ainda são inconsistentes (KARUPAIAH \& SUNDRAM, 2007).

Fórmulas artificiais contendo o ácido palmítico esterificado na posição sn-2 também apresentaram melhor desempenho comparadas às que possuíam o ácido palmítico nas posições sn-1,3 (CARNIELLI et al., 1995; FILER et al., 1969).

A Tabela 2 apresenta a composição em ácidos graxos da gordura do leite humano.

Tabela 2. Distribuição dos principais ácidos graxos no leite humano.

\begin{tabular}{ccccc}
\hline $\begin{array}{c}\text { Ácidos } \\
\text { Graxos }\end{array}$ & $\begin{array}{c}\text { Total } \\
(\%)\end{array}$ & $\begin{array}{c}\text { Posição sn-2 } \\
(\%)\end{array}$ & $\begin{array}{c}\text { Proporção sn-2 } \\
(\%)\end{array}$ & $\begin{array}{c}\text { Posições sn- } \\
1,3^{\mathrm{b}} \\
(\%)\end{array}$ \\
\hline $12: 0$ & 4,9 & 5,3 & & 4,7 \\
$14: 0$ & 6,6 & 11,2 & 36,0 & 4,3 \\
$16: 0$ & 21,8 & 44,8 & 57,0 & 10,3 \\
$18: 0$ & 8,0 & 1,2 & 68,0 & 11,4 \\
$18: 1 \mathrm{n}-9$ & 33,9 & 9,2 & 5,0 & 46,3 \\
$18: 2 \mathrm{n}-6$ & 13,2 & 7,1 & 9,0 & 16,3 \\
$18: 3 \mathrm{n}-3$ & 1,2 & - & 18,0 & - \\
\hline $\mathrm{a}=(s n-2 \times 100) /(3 \times$ total $)$ & & - & \\
$\mathrm{b}$ & $=(3 \times$ total - sn-2)/2 & & &
\end{tabular}

Lien et al. (1997) 
SILVA et al. (2007) investigaram a composição em ácidos graxos de 32 amostras de leite humano provenientes do Banco de Leite Humano do Hospital Universitário da Universidade de São Paulo. O leite de mães brasileiras apresentou composição em ácidos palmítico, oléico e linoléico muito próxima à descrita por LIEN et al. (1997), em leite de mães americanas.

\subsection{MODIFICAÇÃO DE LIPÍDIOS}

Lipídios estruturados podem ser definidos como triacilgliceróis reestruturados ou modificados para alterar a composição em ácidos graxos e/ou sua distribuição nas moléculas de glicerol, por métodos químicos, enzimáticos ou de engenharia genética (LEE \& AKOH, 1998; OSBORN \& AKOH, 2002). Podem ser sintetizados com o propósito de melhorar ou modificar características físicas (polimorfismo, ponto de fusão, conteúdo de gordura sólida, viscosidade e consistência) e/ou químicas (estabilidade oxidativa) dos triacilgliceróis, bem como para modificar uma ou mais propriedades nutricionais (presença ou ausência de ácidos graxos saturados ou insaturados de fácil absorção e digestão). Também podem apresentar características favoráveis quanto à resposta imune, síntese de eicosanóides e ações antiinflamatórias (AKOH \& MOUSSATA, 1998). Com o aumento do conhecimento sobre os efeitos dos ácidos graxos relacionados ao comprimento da cadeia, insaturação e distribuição esteroespecífica no metabolismo e saúde, há crescente interesse em usar óleos e gorduras para a redução do risco de doenças, bem como para a melhoria da saúde (WILLIS et al., 1998). Considerar apenas a estrutura dos ácidos graxos não explica satisfatoriamente o impacto dos lipídios da dieta na composição lipídica do sangue, uma vez que a posição dos ácidos graxos nos triacilgliceróis também tem influência nos níveis de lipídios plasmáticos (DUBOIS et al., 2007). A estereospecificidade e comprimento de cadeia dos ácidos graxos nas posições sn-1, sn-2 e sn-3 dos triacilgliceróis determinam o desempenho metabólico da gordura durante a digestão e absorção, sendo que há substancial conservação nos quilomicrons após a digestão dos ácidos graxos presentes na posição sn-2 dos triacilgliceróis ingeridos, bem como da estrutura estereoespecífica dos triacilglicerós (KARUPAIAH \& SUNDRAM, 2007).

Os lipídios estruturados são normalmente obtidos por interesterificação. Este processo promove mudança na distribuição dos ácidos graxos nos triacilgliceróis, 
afetando a natureza física e o comportamento dos lipídios. A interesterificação, catalisada por via química ou enzimática, é utilizada na indústria de óleos e gorduras para a fabricação de margarinas e "shortenings" e atualmente tem sido bastante empregada em virtude da preocupação com as gorduras parcialmente hidrogenadas que contêm ácidos graxos trans, que são associadas com aumento do risco de doenças cardivoasculares (GIOIELLI, 2002; HUI, 1996; MU \& PORSGAARD, 2005; KARUPAIAH \& SUNDRAM, 2007).

\subsection{INTERESTERIFICAÇÃO QUÍMICA}

A interesterificação química é uma reação ao acaso que produz completa randomização dos ácidos graxos nos triacilgliceróis. Atualmente, sob a perspectiva de custo e aplicação em larga escala, a interesterificação química parece ser o método mais atrativo. Por outro lado, a reação não tem especifidade e oferece pouco ou nenhum controle sobre a distribuição posicional dos ácidos graxos no produto final (WILLIS \& MARANGONI, 1999).

$A$ reação de interesterificação pode ser representada como:

$$
\mathrm{R}_{1}-\mathrm{CO}-\mathrm{OR}_{2}+\mathrm{R}_{3}-\mathrm{CO}-\mathrm{OR}_{4} \rightarrow \mathrm{R}_{1}-\mathrm{CO}-\mathrm{OR}_{4}+\mathrm{R}_{3} \mathrm{CO}-\mathrm{OR}_{2}
$$

A reação é catalisada por metais alcalinos ou aquilatos metálicos, realizada normalmente em temperaturas na faixa de $50-90 \stackrel{\circ}{\circ}$ e necessita baixos teores de umidade, acidez e peróxidos na matéria-prima. Além disso, ao produzir a randomização dos triacilgliceróis, diversos produtos indesejáveis, como sabões, ésteres metílicos e mono e diacilgliceróis são formados durante a reação, exigindo refinação posterior (AKOH, 1998; RIBEIRO et al., 2007).

\subsection{INTERESTERIFICAÇÃO ENZIMÁTICA}

Sob a perspectiva de produzir lipídios com composições específicas para aplicações funcionais e medicinais, os métodos de interesterificação enzimática são mais interessantes (WILLIS et al., 1998; CRIADO et al., 2007). O uso de lipases como biocatalisadores para a modificação da estrutura dos triacilgliceróis vem crescendo.

As lipases ocorrem na natureza e são ativas na interface óleo-água de emulsões (LEE \& AKOH,1998). São enzimas obtidas predominantemente de bactérias, leveduras e fungos (MACRAE, 1983; JAEGER et al., 1994; OLIVEIRA et 
al., 1999; GUNSTONE, 1999). Importantes aplicações têm sido realizadas nas indústrias alimentícias e farmacêuticas. A maioria das reações enzimáticas é realizada em reatores por bateladas, apresentando alguns inconvenientes como altos custos operacionais, baixa produtividade, alta variação na qualidade dos produtos obtidos e problemas de remoção da enzima (RIOS et al., 2004).

Visando a obtenção de reações com maior uniformidade tecnológica e viabilidade econômica, a utilização de enzimas na forma imobilizada permite considerável aumento na estabilidade e maior diversidade de aplicação, de fundamental importância para o desenvolvimento de processos associados à bioconversão (HILAL \& NIGMATULLIN, 2004). A utilização de enzimas imobilizadas confere maior produtividade, facilidade na automação de processos e operações contínuas, controle preciso da extensão das reações, facilidade de separação dos produtos obtidos, estabilização da atividade enzimática, facilidade de recuperação e reutilização das enzimas (SWAISGOOD, 1991).

Reatores contínuos são utilizados associados a enzimas imobilizadas para produção em larga escala de lipídios estruturados. O sistema permite a produção em escala comercial, minimiza os custos e facilita o controle do processo, além de produzir poucos sub-produtos e apresentar facilidade de operação (XU, 2002). Em reatores contínuos, como o substrato entra em contato com grande quantidade de enzima, o tempo de reação é menor quando comparado com o reator descontínuo, resultando em menor migração acil.

A interesterificação enzimática tem a vantagem de permitir grande controle sobre a distribuição posicional dos ácidos graxos do produto final, devido à seletividade e regioespecifidade das lipases (WILLIS \& MARANGONI, 1999). As lipases hidrolisam os triacilgliceróis em monoacilgliceróis, diacilgliceróis, ácidos graxos livres e glicerol. Além da reação de interesterificação, as lipases podem também catalizar as reações de esterificação direta, de acidólise e de alcoólise (LEE \& AKOH, 1998), representadas a seguir:

Esterificação direta:

$$
\mathrm{R}_{1}-\mathrm{CO}-\mathrm{OH}+\mathrm{R}-\mathrm{OH} \longrightarrow \mathrm{R}_{1}-\mathrm{CO}-\mathrm{OR}+\mathrm{H}_{2} \mathrm{O}
$$

Acidólise:

$$
\mathrm{R}_{1}-\mathrm{CO}-\mathrm{OR}+\mathrm{R}_{1}-\mathrm{CO}-\mathrm{OH} \longrightarrow \mathrm{R}_{2}-\mathrm{CO}-\mathrm{OR}+\mathrm{R}_{1}-\mathrm{CO}-\mathrm{OH}
$$

Alcoólise:

$$
\mathrm{R}-\mathrm{CO}-\mathrm{OR}_{1}+\mathrm{R}_{2}-\mathrm{OH} \longrightarrow \mathrm{R}-\mathrm{CO}-\mathrm{OR}_{2}+\mathrm{R}_{1}-\mathrm{OH}
$$


As reações catalisadas por lipases são a combinação de hidrólise e esterificação. A atividade de água água deve ser controlada, para aumentar a esterificação e minimizar a hidrólise, aumentando a taxa de conversão. Quando o excesso de água é presente, a hidrólise é predominante, resultando em acúmulo de glicerol, ácidos graxos livres, mono e diacilgliceróis (OSBORN \& AKOH, 2002). As temperaturas comumente usadas são ao redor de 70ㄷ (SHAHANI, 1975; HAUMMAN, 1994; CRIADO et al., 2007; MADUKO et al., 2007a).

Os lipídios estruturados podem ser produzidos com a utilização de lipases em solventes orgânicos, na qual os substratos são solúveis e a hidrólise pode ser minimizada. O tipo de solvente empregado pode afetar drasticamente a cinética da reação e aumentar a eficiência da enzima. Outros fatores que afetam a atividade enzimática são o $\mathrm{pH}$, a proporção molar dos substratos, o tempo de incubação e a especificidade da enzima (AKOH, 1998).

\subsection{LIPÍDIOS ESTRUTURADOS - SUCEDÂNEOS DOS LIPÍDIOS DO LEITE HUMANO}

As melhorias do desenvolvimento de fórmulas infantis se deram paralelamente aos avanços das técnicas analíticas que permitiram determinação mais precisa de vários nutrientes e seus correspondentes níveis no leite humano. Conseqüentemente, tentativas em combinar a composição do leite humano focalizaram primeiramente na quantidade dos nutrientes. Posteriormente, ficou claro que a qualidade destes nutrientes é crítica quanto a sua biodisponibilidade (BENSON \& MASOR, 1994). Como exemplo, se passou a selecionar os óleos vegetais a partir do perfil de ácidos graxos para serem usados como componente lipídico da fórmula infantil. A maior parte das fórmulas infantis é produzida por mistura de diferentes óleos vegetais ou misturas da gordura do leite bovino e óleos vegetais, que são similares quanto ao perfil de ácidos graxos do leite humano. No entanto, como são diferentes quanto à distribuição estereoespecífica, ocorrem problemas aos recém-nascidos que se alimentam de fórmulas artificiais (STRAARUP et al., 2006).

Diversas pesquisas foram feitas para avaliar a absorção de lipídios estruturados substitutos da gordura do leite humano (QUINLAN \& MOORE, 1993; DE FOUW et al., 1994; LIEN et al., 1996; INNIS et al., 1995; INNIS et al., 1996). 
A gordura de leite humano pode ser sintetizada artificialmente para a produção de fórmulas infantis com manutenção de suas propriedades físicas, químicas e nutritivas (SILVA \& GIOIELLI, 2006; SILVA et al., 2007; MADUKO et al., 2007a, b).

KENNEDY (1991) relatou algumas vantagens dos lipídios estruturados e, dentre elas, o fato destes melhorarem a função do sistema imunológico. $O$ excesso de ácido araquidônico, decorrente de dietas ricas em ácidos graxos n-6 leva a um excesso de eicosanóides, que podem suprimir funções imunológicas como a produção de anticorpos. Esta característica se mostra essencial aos recémnascidos que se alimentam de fórmulas artificiais.

KENNEDY et al. (1999) relataram que a ingestão de lipídios estruturados por recém-nascidos aumentou a absorção dos ácidos graxos, de cálcio, provocou diminuição na formação de sabões de cálcio e, conseqüente, aumento na mineralização dos ossos.

Muitos pesquisadores comprovaram que a estrutura dos lipídios do leite humano pode ser artificialmente produzida pela interesterificação enzimática utilizando como catalisador a lipase específica sn-1,3 (QUINLAN \& CHANDLER, 1992; CHRISTENSEN \& HOLMER, 1993; MUKHERJEE \& KIEWITT, 1998; GUNSTONE, 1999; QUINLAN \& MOORE, 1993; XU et al., 2000a; XU et al., 2000b, YANG et al., 2003a; YANG et al., 2003b; SAHIN et al., 2005).

Pesquisadores patentearam diferentes métodos de produção de lipídios estruturados e utilização em fórmulas infantis na Europa (AKIMMOTO et al., 1999) e na Austrália (QUINLAN \& CHANDLER, 1992).

Diferentes tipos de óleos e gorduras são utilizados como substratos para a produção de lipídios estruturados substitutos da gordura do leite humano, como o tripalmitoilglicerol, gordura suína (banha), gordura do leite bovino, óleo de soja, óleo de canola, óleo de borage e óleo de girassol.

Dentre eles, a banha possui características favoráveis à utilização como matéria-prima para a produção de lipídios estruturados substitutos da gordura do leite humano, pois, diferentemente da gordura corpórea humana e de outros mamíferos, apresenta distribuição de ácidos graxos específica, com o ácido palmítico preferencialmente esterificado na posição sn-2, tipo de estrutura encontrada na gordura do leite humano (BROCKERHOFF et al., 1966; BRECKERIDGE et al., 1969; PARODI, 1982; CHRISTIE \& MOORE, 1970; 
CHRISTIE, 1986; INNIS et al., 1996). A banha é rica nos ácidos palmítico e oléico, na proporção aproximada de 1:2, que correspondem a cerca de $75 \%$ de seus ácidos graxos. Devido à predominância do ácido palmítico na posição sn-2, os principais triacilgliceróis da banha são StPO, OPL e OPO (onde St = esteárico, $\mathrm{P}=$ palmítico, $O=$ oléico e $L=$ linoléico) (KARUPAIAH \& SUNDRAM, 2007). Mais da metade dos triacilgliceróis é composta por esses dois ácidos graxos. Dentro de certos limites, a composição da gordura dos suínos pode ser influenciada pela sua dieta, sendo que cerca de $30 \%$ do peso da carcaça é de gordura, podendo chegar a $50 \%$ em animais excessivamente gordos (O' BRIEN, 1998). Os avanços da zootecnia trouxeram acréscimos nas quantidades de ácidos graxos poliinsaturados aos tecidos adiposos de suínos (GLÄSER et al., 2004). A carne suína é a mais consumida no mundo, segundo dados do USDA (2007) com projeções de crescimento para os próximos anos, o que torna a banha, subproduto da produção de carnes, uma matéria-prima de baixo custo.

SILVA \& GIOIELLI (2006) produziram lipídios estruturados a partir da interesterificação de banha e óleo de soja em diferentes proporções usando como catalisador o metóxido de sódio. Dentre as misturas modificadas, as que continham banha com 20 e $40 \%$ de óleo de soja foram as que mais se aproximaram da composição em ácidos graxos dos lipídios do leite humano.

A empresa Unilever comercializa um sucedâneo dos lipídios do leite humano com o nome comercial BETAPOLTM, que foi o primeiro lipídio estruturado comercial obtido por via enzimática (OSBORN \& $\mathrm{AKOH}, 2002)$. O triacilglicerol predominante no Betapol é o 1,3-dioleil 2-palmitoilglicerol, cuja estrutura pode ser observada na Figura 1. 


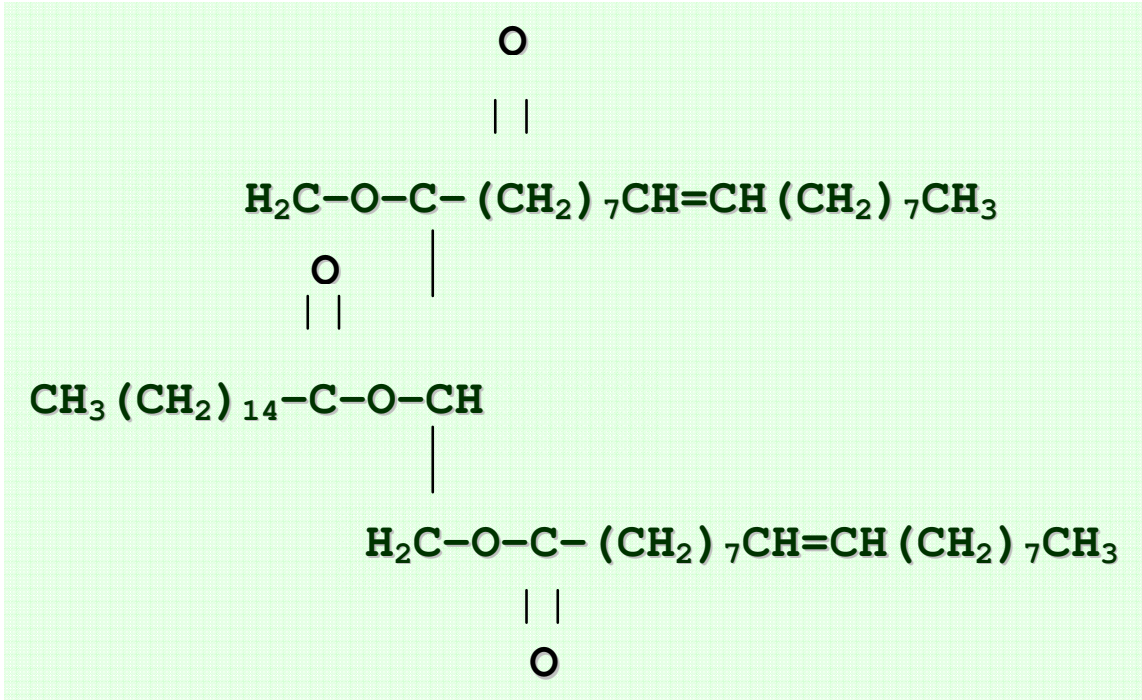

Figura 1. Estrutura do principal triacilglicerol do Betapol.

O Betapol baseia-se na modificação enzimática de tripalmitoilglicerol e óleo de girassol de alto teor de oléico ou óleo de soja, empregando lipase sn-1,3 específica. O produto formado consiste principalmente em mistura de triacilgliceróis do tipo insaturado - palmítico - insaturado (IPI, onde $\mathrm{P}=$ palmítico e $\mathrm{I}=$ insaturado, que pode ser ácido oléico ou linoléico). O esquema da reação pode ser observado na Figura 2. O produto é usado como constituinte de formulações para crianças, pois simula a gordura do leite humano quanto às suas características (QUINLAN \& MOORE, 1993).

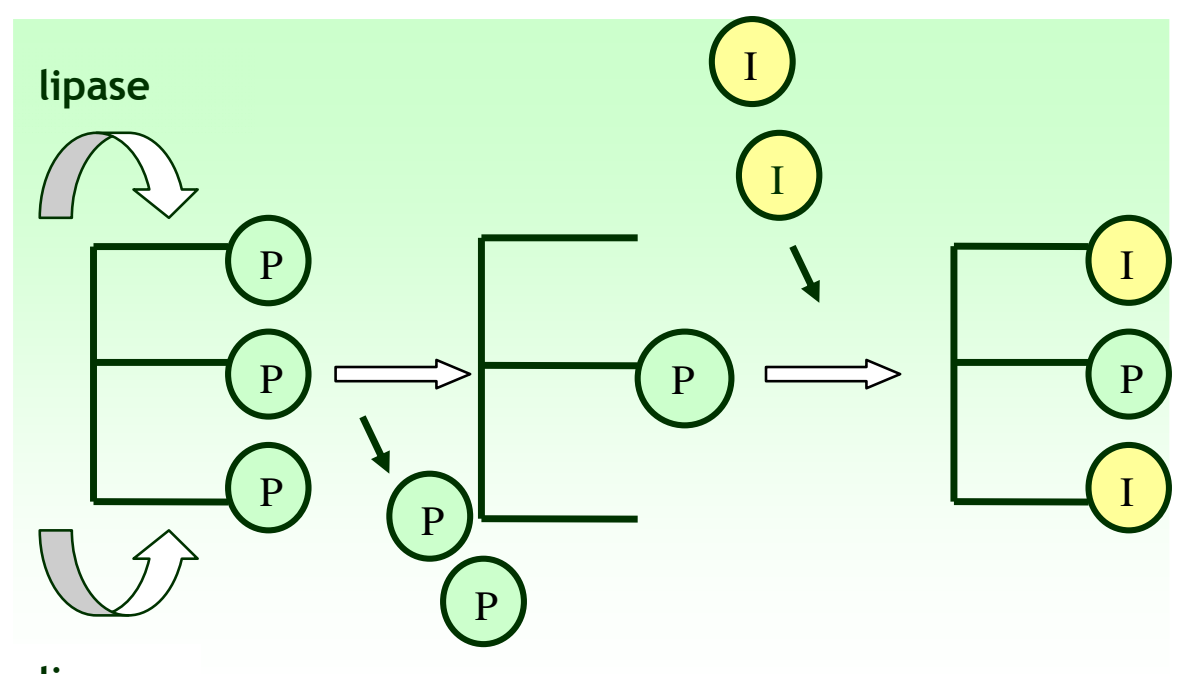

lipase

Figura 2. Esquema de produção do Betapol. 
SILVA et al. (2007) compararam as propriedades físicas da gordura do leite humano e do Betapol e concluíram que o Betapol apresenta menores valores para a consistência, conteúdo de gordura sólida e pontos de fusão e amolecimento que a gordura do leite humano. Os comportamentos de cristalização também foram diferentes.

CHRISTENSEN \& HOLMER (1993) investigaram a composição em ácidos graxos do leite humano de 5 mulheres para servir de parâmetro na produção de um substituto da gordura do leite humano. Para a interesterificação foi utilizada como matéria-prima a gordura do leite bovino e como biocatalisador da reação foi utilizada a enzima sn-1,3 específica de Rhizomucor miehei. Obteve-se lipídio de diferente composição em ácidos graxos quando comparado à gordura do leite humano, mas com semelhante distribuição estereoespecífica na cadeia dos triacilgliceróis, contendo a maior parte do ácido palmítico esterificado na posição sn-2.

MUKHERJEE \& KIEWITT (1998) relataram a interesterificação enzimática entre a tripalmitoilglicerol e óleo de canola. A reação foi catalisada por duas lipases, a enzima comercial Lipozyme IM e a lipase extraída do látex purificado do fruto Carica papaya. As condições da reação corresponderam a 6 horas, $60^{\circ} \mathrm{C}$ e $9 \%$ de cada enzima. Os resultados indicaram que ambos lipídios obtidos tiveram em sua estrutura de triacilgliceróis o ácido palmítico predominantemente esterificado na posição $s n-2$, enquanto os ácidos poliinsaturados provenientes do óleo de canola foram esterificados nas posições $s n-1,3$, características essenciais em análogos da gordura do leite humano.

Pesquisas reportam que o ácido araquidônico tem função de acelerar o crescimento de recém-nascidos (CARLSON et al., 1993; LANTING et al., 1994). SHIMADA et al. (2000) utilizaram a acidólise do tripalmitoilglicerol com ácido araquidônico usando a lipase sn-1,3 específica de Rhizopus delemar para sintetizar o 1,3-araquidonoil-2-palmitoil-glicerol. A mistura de ácido araquidônico/tripalmitoilglicerol (5:1) foi adicionada de $0,2 \mathrm{~g}$ de água e $0,7 \mathrm{~g}$ da lipase imobilizada e incubada a $40 \stackrel{\circ}{\mathrm{C}}$ por $24 \mathrm{~h}$. O produto obtido apresentou cerca de $60 \%$ do ácido araquidônico esterificado nas posições sn-1,3 e cerca de 30\% do ácido palmítico esterificado na posição sn-2, demonstrando ter características favoráveis à sua utilização como sucedâneo da gordura do leite humano.

YANG et al. (2003a) interesterificaram a banha e os ácidos graxos do óleo de soja utilizando a enzima Lipozyme $\mathrm{IM}^{\circledR}$ de Rhizomucor miehei. Foram utilizadas as 
seguintes condições de reação: temperatura de $61 \stackrel{\circ}{\circ}$, $3,5 \%$ de água, $13,7 \%$ de enzima, incubação por $1 \mathrm{~h}$ na mistura banha/ácidos graxos do óleo de soja na proporção de $1 / 2,4$. Os autores obtiveram lipídio estruturado com características semelhantes à gordura do leite humano de mães chinesas quanto à composição em ácidos graxos e distribuição estereoespecífica.

YANG et al. (2003b) utilizaram as enzimas Lipozyme IM $® T L$ de Thermomyces lanuginosa para interesterificar o tripalmitoilglicerol com ácido caprílico e óleo de girassol, visando produzir lipídio estruturado semelhante ao lipídio do leite humano. As melhores incorporações de ácido palmítico (42\%) foram obtidas nas seguintes condições: $20 \%$ de enzima por 20 h de reação a $40{ }^{\circ} \mathrm{C}$.

YANG et al. (2005) interesterificaram enzimaticamente tripalmitoilglicerol e ácido linoléico conjugado para a obtenção de um sucedâneo da gordura do leite humano. Foi obtida reduzida taxa de migração acil com a utilização de hexano como solvente da reação.

Estudos recentes apontam interesse em suplementar fórmulas infantis com ácidos graxos como o gama-linolênico (GLA), araquidônico (AA), eicosapentaenóico (EPA) e docosahexaenóico (DHA) (SAHIN et al., 2005). Fórmulas infantis contendo GLA, principalmente proveniente do óleo de borage, são utilizadas para agregar benefícios à saúde e exercer efeito antagônico no metabolismo do ácido araquidônico (KAWASHIMA et al., 2002; WATKINS \& GERMAN, 2002). O GLA é rapidamente elongado a ácido di-homo- $\gamma$-linolênico e subsequentemente, pela ação da $\Delta 5$-desaturase, a ácido araquidônico. Sendo assim, o GLA é a alternativa de menor custo e de mais fácil acesso para a suplementação de ácido araquidônico em fórmulas infantis (REDDEN et al., 1998; FEWTRELL et al., 2004; COUGH, 2001; DUBOIS et al., 2007).

SAHIN et al. (2005a) interesterificaram tripalmitoilglicerol com uma mistura de ácidos graxos de óleo de avelãs e óleo de borage rico em GLA, na expectativa de obter lipídio a ser utilizado como sucedâneo da gordura do leite humano. Foram utilizadas como biocatalisadores as lipases comerciais Lipozyme ${ }^{\circledR}$ RM IM (10\%) e Lipozyme ${ }^{\circledR}$ TL IM (6\%), e para o modelo estudado as melhores condições foram: $14,8 \mathrm{~mol} / \mathrm{mol}$ (ácido graxos/tripalmitoilglicerol) e reação durante 24 horas a $55^{\circ} \mathrm{C}$. O efeito de incorporação do GLA e do ácido oléico foi semelhante para ambas as enzimas. Os lipídios estruturados produzidos com a Lipozyme ${ }^{\circledR} \mathrm{RM}$ IM e a 
Lipozyme $^{\circledR}$ TL IM continham 74,9\% e 73,9\% de ácido palmítico, respectivamente, sendo que este foi esterificado principalmente na posição sn-2.

SAHIN et al. (2005b) interesterificaram tripalmitoilglicerol com mistura de ácidos graxos do óleo de avelãs e ácido esteárico, utilizando como catalisador a lipase Lipozyme RM IM (10\%). Obtiveram melhor incorporação de ácido oléico (47,1\%) a 65 ํC após 24 horas de reação, com relação molar de 1:3:0,75.

SRIVASTAVA et al. (2006), a partir da mistura tripalmitoilglicerol e ácido oléico em diferentes proporções, estudaram a utilização de enzima não específica LIP1 do microorganismo Candida rugosa para a produção de substituto da gordura do leite humano. Concluíram que a incorporação de ácido oléico ao tripalmitoilglicerol foi consideravelmente menor quando se utilizou a lipase LIP1, comparando à lipase sn-1,3 específica Lipozyme ${ }^{\circledR} \mathrm{RM} I \mathrm{IM}$.

NIELSEN et al. (2006) produziram lipídio estruturado em reator contínuo utilizando banha e ácidos graxos do óleo de soja para obtenção de substituto da gordura do leite humano, utilizando a lipase sn-1,3 específica Lipozyme ${ }^{\circledR} \mathrm{RM}$ IM. À mistura de ácidos graxos e banha (3:1) foram adicionados $0,1 \%$ de água, e a reação se processou a $65 \stackrel{\circ}{\mathrm{C}}$ por $1,5 \mathrm{~h}$. Os autores obtiveram lipídio estruturado com características semelhantes à gordura do leite humano, mas com baixa estabilidade oxidativa quando comparado a produtos comerciais.

MADUKO et al. (2007a) interesterificaram tripalmitoilglicerol com mistura dos óleos de coco, açafroa e soja $(2,5: 1,1: 0,8)$ na tentativa de obter composição de ácidos graxos semelhantes à da gordura do leite humano. A reação utilizou $10 \%$ do catalisador Lipozyme ${ }^{\circledR}$ RM IM. A melhor incorporação do ácido palmítico (40-55\%) à posição sn-2 foi obtida com $3 \mathrm{~mol} / \mathrm{mol}$ de relação molar (mistura de óleos/tripalmitoilglicerol) na temperatura de $55{ }^{\circ} \mathrm{C}$ e $14,4 \mathrm{~h}$ de reação.

MADUKO et al. (2007b) produziram fórmula artificial de leite contendo lipídio estruturado e leite caprino pasteurizado. Concluíram que o leite análogo obtido apresentou composição semelhante ao leite humano quanto à composição em ácidos graxos e distribuição nas cadeias dos triacilgliceróis. Melhores resultados foram obtidos quando a fórmula continha proporção de 1:10 de tripalmitoilglicerol:mistura de óleos de coco, açafroa e soja $(2,5: 1,1: 0,8)$.

O efeito de lipídios estruturados nos níveis de colesterol e lipoproteínas do sangue parece ser mínimo quando comparado às gorduras de origem com composições em ácidos graxos similares, mas com diferentes estruturas de 
triacilgliceróis. Isto indica que a utilização de lipídios estruturados na dieta não leva a efeitos deletérios nos acima citados parâmetros do sangue (MU \& PORSGAARD, 2005).

Apesar das inúmeras pesquisas realizadas envolvendo diversos processos e matérias-primas, o objetivo de desenvolver lipídios estruturados semelhantes à gordura do leite humano ainda está distante de ser totalmente alcançado. Além disso, mais pesquisas deverão ser conduzidas para avaliar o desempenho destes lipídios em recém-nascidos.

\subsection{CONCLUSÕES}

Os lipídios estruturados sucedâneos da gordura do leite humano devem apresentar em sua estrutura o ácido palmítico esterificado principalmente na posição $s n-2$ dos triacilgliceróis, característica fundamental para adequada dieta do recém-nascido, garantindo melhor absorção dos nutrientes e diminuição das perdas.

Os lipídios estruturados sucedâneos da gordura do leite humano devem conter em sua composição ácidos graxos essenciais, importantes para o desenvolvimento do sistema nervoso e estimulação do sistema imunológico.

As lipases com especificidade para as posições sn-1,3 dos triacilgliceróis demonstram ser alternativa interessante no desenvolvimento de sucedâneos da gordura do leite humano. 


\subsection{REFERÊNCIAS BIBLIOGRÁFICAS}

AGÊNCIA NACIONAL DE VIGILÂNCIA SANITÁRIA. Legislação. VisaLegis. Resolução n.482, de 23 de setembro de 1999. A Agência Nacional de Vigilância Sanitária aprova o "Regulamento técnico para óleos vegetais, gorduras vegetais e creme vegetal". Disponível em: http://www.anvisa.gov.br/legis.resol.482 99.htm. Acesso em: 9 nov. 2004.

AGOSTINI, C. Compliance of present recommendations of fatty acids in formulas for term infants with the actual human milk fatty acid composition in different populations. Acta Paediatrica, v.92, n.7, p.785-789, 2003.

AGOSTONI, C.; GIOVANNINI, M. Cognitive and visual development: Influence of differences in breast and formula fed infants. Nutrition \& Health, v.15, n.3/4, p.183-188, 2001.

AKIMMOTO, K.; YAMAGUCHI, T.; FUJIKAWA, S. Novel triglyceride and composition comprising the same. EP 0965578 A1, 1999.

AKOH, C.C. Structured lipids. In: AKOH, C.C.; MIN, D.B., ed. Food lipids chemistry, nutrition, and biotechnology. New York: Marcel Dekker. 1998. p. 699-727.

AKOH, C.C.; MOUSSATA C.O. Lipase-catalysed modification of borage oil: incorporation of capric and eicosapentanoic acids to form a strutured lipid. Journal of the American Oil Chemists' Society. v.75, n.6, p.697-701, 1998.

ANDERSON, J.W.; JOHNSTONE, B.M.; RAMLEY, D.T. Breast-feeding and cognitive development: a meta-analysis. American Journal of Clinical Nutrition. v.70, n.4, p.525-535, 1999.

BENSON, J.D.; MASOR, M.L. Infant formula development: past, present and future. Endocrine Regulations. v.28, n.1, p.9-16, 1994.

BEZKOROVAINY, A. Probiotics: determinants of survival and growth in the gut. American Journal of Clinical Nutrition. v. 73, n.2, p. 399S-405S, 2001. 
BITMAN, J.; FREED, L.M.; NEVILLE, M.C. Lipid composition prepartum human mammary secretion and postpartum milk. Journal of Pediatric Gastroenterology and Nutrition v.5, n.4, p.608-615, 1986.

BROCKERHOFF, H.; HOYLE, R.J.; WOLMARK, N. Positional distribution of fatty acids in triglycerides of animal depot fats, Biochimica et Biophysica Acta (BBA) Lipids and Lipid Metabolism. v.116, n.1, p. 67-72, 1966.

CALHOUN, D.A.; LUNOE, M.; DU, Y.; CHRISTENSEN, R.D. Granulocyte colonystimulating factor is present in human milk and its receptor is present in human fetal intestine. Pediatrics. v. 105, n. 1, e7, 2000.

CARNIELLI, V.P.; LUIJENDIJK, I.H.T.; VANGOUDOEVER, J.B.; SUKERS, E.J.; BOERLAGE, A.A.; DEGENHART, H.J.; SAUER, P.J.J.C. Structural position and the amount of palmitic acid in infant formulas: effect on fat, fatty acid, and mineral balance. Journal of Pediatric Gastroenterology and Nutrition. v.23, n.5, p.553$560,1996$.

CARNIELLI, V.P.; LUIJENDIJK, I.H.T.; VANGOUDOEVER, J.B.; SUKERS, E.J.; BOERLAGE, A.A.; DEGENHART, H.J., SAUER, P.J.J. Feeding premature newborn infants palmitic acid in amounts and stereoisomeric position similar to human milk: effects on fat and mineral balance. American Journal of Clinical Nutrition. v.61, n.5, p.1037-1042, 1995.

CARLSON, S.E.; RHODES, P.G.; FERGUSON, M.G. Docosahexaenoic acid status of preterm infants at birth and following feeding with human milk or formula. American Journal of Clinical Nutrition, v. 44, n.6, p.798-804, 1986.

CARLSON, S.E.; COOKE, R.J.; RHODES, P.G.; RHODES, G.P.; PEEPLES, J.M.H.; WERKMAN, R.N.S. Journal of Pediatrics. v.120, n. 4, p.S159-S167,1992.

CARRIERE, F.; BARROWMAN, J.A.; VERGER, R.; LAUGIER, R. Secretion and contribuition to lipolysis of gastric and pancreatic lipases during a test meal in humans. Gastroenterology, v.105, n.3, p.876-888, 1993. 
CHANG, M.K.; ABRAHAM, G.; JOHN, V.T. Production of cocoa butter-like fat from interesterification of vegetable oils. Journal of the American Oil Chemists' Society. v.67, p.832-834, 1990.

CHAPPEL, J.E.; CLANDININ, M.T.; KEARNY-VOLPE, C.; REICHMAN, B.; SWYER, P.W. Fatty acid balance studies in premature infants fed human milk or formula: effect of calcium supplementation. Journal of Pediatrics. v.108, n.3, p.439-447, 1986.

CHRISTENSEN, T.C.; HOLMER, G. Lipase catalysed acyl-exchage reactions of butter oil. Synthesis of a human milk fat substitute for infant formulas. Milchwissenschaft - Milk Science International. v.48, n.10, p.543-547, 1993.

CHRISTIE, W.W. Composition and structure of milk lipids. In: FOX, P.F., ed. Advanced dairy chemistry: lipids. 2.ed. London, New York: Chapman \& Hall, 1995. v.2, p.1-36.

CLARK, R.M.; HUNDRIESER, K.E. A lack of correlation among fatty-acids associated with different lipid classes in human-milk. Lipids, v.28, n.2, p.157-159 1993.

CLOUGH, P.M. Specialty vegetable oils containing g-linolenic acid and stearidonic acid. In: GUNSTONE, F.D., ed. Structured and modified lipids. New York: Marcel Dekker, 2001. p.75-117.

CRIADO, M.; HERNANDÉZ-MARTINS, E.; LOPÉZ-HERNADÉZ, A.; OTERO, C. Enzymatic Interesterification of Extra Virgin Olive Oil with a Fully Hydrogenated Fat: Characterization of the Reaction and Its Products. Journal of the American Oil Chemists' Society. v.84, n.8, p.717-726, 2007.

DE FOUW, N.J.; KIVITS, G.A.A.; QUINLAN, P.T.; VAN NIELEN, W.G.L. Absorption of isomeric palmitic acid-containing triacylglycerols resembling human milk fat in the adult rat. Lipids. v.29, n.4, p.765-770, 1994. 
DUBOIS, V.; BRETON, S.; LINDER, M.; FANNI, J.; PARMENTIER, M. Fatty acid profiles of 80 vegetable oils with regard to their nutritional potential. European Journal of Lipid Science and Technology. v. 109, n.7, p.710-732, 2007.

FEWTRELL, M.S.; ABBOTT, R.A.; KENNEDY, K.; SINGHAL, A.; MORLEY, R.; CAINE, E.; JAMIESON, C.; COCKBURN, F.; LUCAS, A. Randomized, Doubleblind Trial of Long-Chain Polyunsaturated Fatty Acid Supplementation with Fish Oil and Borage Oil in Preterm Infants. Journal of Pediatrics. v.145, n.4, p.471479, 2004.

FILER, I.J.; MATTSON, F.H.; FOMON, S.J. Triglyceride configuration and fat absotion by the human infant. Journal of Nutrition. v.99, n.3, p.293-298, 1969.

FORSYNTH, J.S. Lipids and infant formulas. Nutrition Research Review. v.11, n.2, p.255-278, 1998.

GIOIELLI, L.A. Lipídios estruturados. In: CURI, R.; POMPÉIA, C.; MIYASAKA, C.K.; PROCOPIO, J., eds. Entendendo a gordura: os ácidos graxos. São Paulo: Manole, 2002. p.457-465.

GLÄSER, K.R.; WENK, C.; SCHEEDER, R.L. Evaluation of pork backfat firmmes and lard consistency using several different physicochemical methods. Journal of the Science of Food and Agriculture. v.84, n.8, p.853-862, 2004.

GUNSTONE, F.D. Enzymes as biocatalysts in the modification of natural lipids. Journal of the Science of Food and Agriculture. v.79, n.12, p.1535-1549, 1999.

HALL, W.G. Weaning and growth of artificially reared rats. Science. v.190, n.4221, p.1313-1315, 1975.

HARZER, G.; HAUG, M.; DIETERICH, I.; GENTNER, P.R. Changing patterns of human-milk lipids in the course of the lactation and during the day American Journal of Clinical Nutrition. v.37, n.4, p.612-621, 1983.

HAUMMAN, B.F. Tools: hydrogenation, interesterification. INFORM, v.5, n.6, p.668678, 1994. 
HILAL, N.; NIGMATULLIN, R.; ALPATOVA, A. Immobilization of cross-linked lipase aggregates within microporous polymeric membranes. Journal of Membrane Science., v.238, n.1/2, p.131-141, 2004.

HUI, Y.H., ed. Bailey's industrial oil and fat products. 5.ed. New York: Wiley, 1996. p.497-601, 603-654.

INNIS, S.M.; GILLEY, J.; ANDWERKER, J. Are human milk long-chain polyunsaturated fatty acids related to visual and neural development in breastfed term infants? Journal of Pedriatrics. v.139, n.4, p.532-538, 2001.

INNIS, S.M.; DYER, R.; QUINLAN, P.; DIERSEN-SHADE, D. Palmitic acid is absorved as sn-2 monopalmitin from milk and formula with rearraged triacylglycerols and results in increased plasma triglyceride sn-2 and cholesteryl ester palmitate in piglets. Journal of Nutrition. v.125, n.1, 73-81, 1995.

JAEGER, K.E.; RANSAC, S.; DIJKSTRA, B.W.; VAN HEUVEL, M.; MISSET, M. Bacterial lipases. FEMS Microbiology Reviews. v.15, n.1, p.29-63, 1994.

JENSEN, R.G. Lipids in human milk-composition and fat-soluble vitamins. In: Lebenthal E, ed. Textbook of gastroenterology and nutrition in infancy. 2 ed. New York: Raven Press, 1989, p.157-208.

JENSEN, R.G., ed. Handbook of milk composition. San Diego: Academic Press, 1995. 237p. (Food Science and technology international series).

JENSEN, R.G.. The lipids in human milk. Progress in Lipids Research. v.35, n.1, p.53-92,1996.

JENSEN, R.G. Lipids in human milk. Lipids. v.34, n.12, p.1243-1271, 1999.

JENSEN, R.G. Infant formulas. In: GUNSTONE, F.D., ed. Structured and modified lipids. New York: Marcel Dekker, 2001. p.455-464. 
JENSEN, R.G.; FERRIS, A.M.; LAMMI-KEFFE, C.J.; HENDERSON, R.A. Lipids of bovine and human milks: a comparison, Journal of Dairy Science. v.73, n.2, p. 223-240. 1990.

JENSEN, R.G.; HAGERTY, M.M.; MCMAHON, E. Lipids of human milk and infant formulas: a review. American Journal of Clinical Nutrition. v.31, n.6, p.990-1016. 1978.

KARUPAIAH, T.; SUNDRAM, K. Effects of stereospecific positioning of fatty acids in triacylglycerol structures in native and randomized fats: a review of their nutritional implications. Nutrition \& Metabolism. v.4, n.16, p.1-17, 2007.

KAWASHIMA, A.Y.; SHIMADA, T.; NAGAO, A.; OHARA, T.; MATSUHISA, A.; SUGIHARA, Y.; TOMINAGA, Production of Structured TAG Rich in 1,3Dicapryloyl-2-y-linolenoyl Glycerol from Borage Oil. Journal of the American Oil Chemists' Society. v.79, n.9, p.871-877, 2002.

KENNEDY, J.P. Structured Lipids: Fats of the future, Food Technology. v.45, n.1, p.76-83, 1991.

KENNEDY, K.; FEWTRELL, M.S.; MORLEY, R.; ABBOTT, R.; QUILAN, P.T.; WELLS, J.C.K.; BINDELS, J.G.; LUCAS, A. Double-blind, randomized trial of a synthetic triacylglycerol in formula-fed term infants: effects on stool biochemistry, stool characteristics, and bone mineralization. American Journal of Clinical Nutrition. v. 70, n.5, p. 920-927, 1999.

KOLETZKO, B.; THIEL, I.; ABIODUN, P.O. The fatty acid composition of human milk in Europe and Africa. Journal of Pediatrics. v.120, n.2, p.S62-S70, 1992.

LANTING; C.I.; FIDLER V.; HUISMAN, M.; TOUWEN, B.C.; BOERSMA, E.R. Neurological differences between 9-year-old children fed breast-milk or formulamilk as babies. Lancet. v.344, n.8933, p.1319-1322, 1994.

LEE, K.T.; AKOH, C.C. Characterization of enzymatically syntetized structured lipids containing eicosapentaenoic, docosahexanoic and caprylic acids, Journal of the American Oil Chemists' Society. v.75, n.4, p.495-499, 1998. 
LIEN, E.L. The role of fatty acid composition and positional distribution in fat absorption in infants. Journal of Pedriatrics. v.125, n.6, p.S62-S68, 1994.

LIEN, E.L.; BOYLE, F.G.; YUHAS, R.; TOMARELLI, R.M.; QUINLAN, P. Effect of Triglyceride Positional Distribution on Fatty Acid Absorption in Rats. Journal of Pediatric Gastroenterology \& Nutrition. v.25, n.2, p.167-174, 1997.

LÖNNERDAL, B.O. Effects of maternal dietary intake on human milk composition, Journal of Nutrition. v.116, n.4, p. 499-513. 1986.

MACRAE, A.R. Lipase-catalysed interesterification of oils and fats. Journal of the American Oil Chemists' Society. v.60, n.2, p.243A-246A, 1983.

MADUKO, C.O.; AKOH, C.C.; PARK, Y.W. Enzymatic interesterification of Tripalmitin with Vegetable Oil Blends for formulation of Caprine Milk Infant Formula Analogs. Journal of Dairy Science, v.90, n.4, p.594-601, 2007.

MADUKO, C.O.; AKOH, C.C.; PARK, Y.W. Production of Infant Milk Fat Analogs Containing Palmitic Acid: Optimization of Reactions by Response Surface Methodology. Journal of Dairy Science. v.90, n.7, p.2147-2150, 2007.

MARTIN, J.C.; BOUGNOUX, P.; ANTONIE, J.M.; LANSON, M.; COUET, C. Triacylglycerols structure of human colostrum and mature milk. Lipids. v.28, n.7, p.637-643, 1993.

MATTSON, F.H.; VOLPENHEIM, R.A. The digestion and absortion of triglycerides, Journal of Biological Chemistry. v.239, n.9, p.2772-2777, 1964.

MEGRAUD, F.G.; BOUDARA, K.; BESSAND, S.; BENSID, F.; DABIS, R.; SOLTANA, M.; TOUHAHMI. Incidence of bacterial infection in infants in Western Algeria and the possible protective role of breast-feeding. Journal Epidemiology and Infection. v.105, n.1, p.73-78, 1990.

MICHALSKI M.C.; BRIARD, V.; MICHEL, F.; TASSON, F.; POULAIN, P. Size Distribution of Fat Globules in Human Colostrum, Breast Milk, and Infant Formula. Journal of Dairy Science. v.88, n.6, p.1927-1940, 2005. 
MU, H.; PORSGAARD, T. The metabolism of structured triacylglycerols. Progress in Lipid Research. v.44, n.6, p.430-448, 2005.

MUKHERJEE, K.D.; KIEWIT, I. Structured triacylglycerols resembling human milk fat by transesterification catalyzed by papaya (Carica papaya) latex. Biotechnology Letters, v.20, n.6, p.613-616, 1998.

NIELSEN, N.S.; YANG, T.; XU, X.; JACOBSEN, C. Production and oxidative stability of a human milk fat substitute produced from lard by enzyme technology in a pilot packed-bed reactor. Food Chemistry, v.94, n.1, p.53-60, 2006.

O'BRIEN, R.D. Fats and oils: formulating and processing for applications. Lancaster: Technomic, 1998. p.7-10, 33-36, 98-108.

OLIVEIRA, A.L.A.; GIOIELLI, L.A.; OLIVEIRA, M.N. Hidrólise parcial enzimática de gordura de babaçu. Ciência e Tecnologia de Alimentos, São Paulo, v.9, n.2, p.270-276, 1999.

OSBORN, H.T.; AKOH, C.C. Structured lipids - novel fats with medical, nutraceutical, and food applications. Comprehensive Reviews in Food Science and Food Safety, v.3, n.1, p.93-103, 2002.

PONS, S.M.; BARGALLÓ, A.C.; FOLGOSO, C.C.; SABATER, M.C.L. Triacylglycerol composition in colostrum, transitional and mature human milk. European Journal of Clinical Nutrition. v.54, n.12, p.878-882, 2000.

PRENTICE, A. Regional variations in the composition of human milk. In: JENSEN, R.G., ed. Handbook of milk composition. San Diego: Academic Press, 1995. p.115-221. (Food science and technology international series).

QUILAN, P.; MOORE, S. Modification of triglycerides by lipases: process technology and its application to the production of nutritionally improved fats. INFORM. v.4, n.5, p.580-585, 1993.

QUINLAN, P.T.; CHANDLER, I.C. Human milk fat substitutes. AP Au-A-10344/92, 1992. 
REDDEN, P.R.; LIN, X.; HORROBIN, D.F. Di-linóleoyl-mono-g-naturally occurring structured triacylglycerols in evening primrose oil. In: CHRISTOPHE, A.B., ed. Structural modified food fats: synthesis, biochemistry, and use. Champaign: AOCS Press, 1998. p.121-128.

REDE NACIONAL DE BANCOS DE LEITE HUMANO. Disponível em: http://www.fiocruz.br/redeblh/cgi/cgilua.exe/sys/start.htm?tpl=home\#. Acesso em: 11 nov. 2007.

RIBEIRO, A.P.B.; MOURA, J.M.L.N.; GRIMALDI, R.; GONÇALVES, L.A.G. Interesterificação química: alternativa para obtenção de gorduras zero trans. Química Nova. v.30, n.5, p.1295-1300, 2007.

SAHIN, N.; AKOH, C.C.; KARAALI, A. Enzymatic production of human milk fat substitutes containing gamma-linoleic acid: Optimization of reactions by response surface methodology. Journal of the American Oil Chemists' Society. v.82, n.8, p.549-557, 2005a.

SAHIN, N.; AKOH, C.C.; KARAALI, A. Lipase-catalyzed acidolysis of tripalmitin with hazelnut oil fatty acids and stearic acid to produce human milk fat substitutes. Journal of Agricultural and Food Chemistry. v.53, n.14, p.5779-5783, 2005b.

SHIMADA, Y.; NAGAO, T.; HAMASAKI, Y.; AKIMOTO, K.; SUGIHARA, A.; FUJIKAWA, S.; KOMEMUSHI, S.; TOMINAGA, Y. Enzymatic synthesis of structured lipid containing arachidonic and palmitic acids. Journal of the American Oil Chemists' Society. v.77, n.1, p.89-93, 2000.

SILVA, R.C.; COTTING, L.N.; POLTRONIERI, T.P.; BALCÃO, V.M., GIOIELLI, L.A. Physical properties of structured lipids from lard and soybean oil produced by enzymatic interesterification. Ciência e Tecnologia de Alimentos, [Enviado para publicação].

SILVA, R.C.; ESCOBEDO, J.P.; GIOIELLI, L.A. Comportamento de cristalização de lipídios estruturados por interesterificação química de banha e óleo de soja. Química Nova. v.31, n.2, p.330-335, 2008. 
SILVA, R.C.; ESCOBEDO, J.P.; QUINTAL, V.S.; IBIDI, S.M.; ALBUQUERQUE, E.M.; GIOIELLI, L.A. Composição centesimal do leite humano e caracterização das propriedades físicoquímicas de sua gordura. Química Nova. v.30, n.7, p.1535-1538, 2007.

SILVA, R.C.; GIOIELLI, L.A. Propriedades físicas de lipídios estruturados obtidos a partir de banha e óleo de soja. Revista Brasileira de Ciências Farmacêuticas. v.42, n.2, p.223-235, 2006.

SMALL, D.M. The effects pf glyceride structured on absortion and metabolism. Annual Review of Nutrition. v.11, n.1, p.413-434, 1991.

SMIT, E.N.; MARTINI, I.A.; MULDER, H.; BOERSMA, E.R.; MUSKIET, F.A.J. Estimated biological variation of the mature human milk fatty acid composition. Prostaglandins, Leukotrienes \& Essential Fatty Acids. v.66, n.5/6, p.549-555, 2002.

SMIT, E.N.; MARTINI, I.A.; KEMPERMAN, R.F.J.; SCHAAFSMA, A.; MUSLIET, F.A.J.; BOERSMA, E.R. Fatty acids in formulae for term infants: compliance of present recommendations with the actual human milk fatty acid composityion of geographically different populations. Acta Paediatrics. v.92, n.7, p.790-796, 2003.

SREENIVASAN, B. Interesterifcation of fats. Journal of the American Oil Chemists' Society. v.55, n.6, p.796-805, 1978.

STRAARUP, E.M.; LAURITZEN, L.; FAERK, J.; HOY, C.E.; MICHAELSEN, K.F. The stereospecific triacylglycerol structures and fatty acid profiles of human milk and infant formulas. Journal of Pediatric Gastroenterology and Nutrition, v.42, n.3, p.293-299, 2006.

SWAISGOOD, H.E. Immobilized enzymes: application to bioprocessing of food. In: FOX, P.F., ed. Food enzymology. London, New York: Elsevier Applied Science, 1991. v.2, p.309. 
TANTIBHEDHYANGKUL P.; HASHIM S.A. Medium-chain triglyceride feeding in premature infants: effects in calcium and magnesium absorption. Pediatrics. v.61, n.4, p.537-545, 1978.

TOMARELLI, R.M.; MEYER, B.I.; WEABER, I.R.; BERNHART, F.W. Effect of positional distribution on the absorption of the fatty acids of human milk and infant formulas. International Nutrition. v.95, p.583-590, 1968.

UNITED STATES. Department of Agriculture. Nutrient Data Laboratory. USDA National Nutrient Database for Standard Reference: Release 15. 2002. Disponível em: http://www.nal.usda.gov/fnic/foodcomp. Acesso em: 9 set. 2003.

VAN BEUSEKOM, C.M.; NIJEBOER, H.J.; VANDERVEERE, C.N.; LUTEYN, A.J.; OFFRINGA, P.J.; MUSKIET, F.A.J.; BOERSMA, E.R. Indicators of long-chain polyunsaturated fatty-acid status of exclusively breast-fed infants at delivery and after 20-22 days. Early Human Development. v.32, n.2/3, p.207-218, 1993.

WATKINS, S.M.; GERMAN, J.B. Unsaturated Fatty Acids, In AKOH, C.C.; MIN, D.B. Food Lipids: Chemistry, Nutrition, and Biotechnology, 2ed., New York:Marcel Dekker, 2002, pp. 559-588.

WILLIS, W.M.; LENCKI, R.W.; MARANGONI, A.G. Lipid modification strategies in the production of nutritionally functional fats and oils. Critical Reviews in Food Science and Nutrition. v.38, n.8, p.639-674, 1998.

WILLIS, W.M.; MARANGONI, A.G. Assessment of lipase and chemically catalysed lipid modification strategies for the production of structured lipids. Journal of the American Oil Chemists' Society. v.76, n.4, p.443-450, 1999.

WINTER, C.H.; HOVING, E.B.; MUSKIET, F.A.J. Fatty-acid composition of humanmilk triglyceride species - possible consequences for optimal structures of infant formula triglycerides. Journal of Chromatography-Biomedical Applications, v.616, n.1, p. 9-24, 1993

$\mathrm{XU}, \mathrm{X}$. Enzymatic production of structured lipids: process reactions and acyl migration. INFORM. v.11, p.1121-1129, 2000a. 
$\mathrm{XU}, \mathrm{X}$. Production of specific strucured triacylglycerol by lypase-catalysed reactions: a review. European Journal of Lipid Science and Technology. v.102, n.4, p.287303, 2000b.

YANG T.K.; XU, X.B; HE, C.; LI, L.T. Lipase-catalyzed modification of lard to produce human milk fat substitutes. Food Chemistry. v.80, n.4, p.473-481, 2003a.

YANG, T.K.; FRUEKILDE, M.B. Apllications of immobilized Thermomyces lanuginose lipase in interesterification. Journal of the American Oil Chemists' Society. v.80, n.9, p.881-887, 2003b.

YANG, T.K.; REBSDORF, M.; ENGELRUD, U.; Xu, X. Enzymatic production of monoacylglycerols containing polyunsaturated fatty acids through an efficient glycerolysis system. Journal of Agriculture Food Chemistry. v.53, n.5, p.14751481, 2005. 
2. Composição centesimal do leite humano e caracterização das propriedades físicoquímicas de sua gordura e de sucedâneo comercial

SILVA, R.C.; ESCOBEDO, J.P.; QUINTAL, V.S.; IBIDI, S.M.; ALBUQUERQUE, E.M.; GIOIELLI, L.A. Composição centesimal do leite humano e caracterização das propriedades físicoquímicas de sua gordura. Química Nova. v.30, n.7, p.1535-1538, 2007. 


\section{RESUMO}

O leite humano possui características de grande importância para o recémnascido, uma vez que a sua composição apresenta todos os nutrientes em quantidade e qualidade necessárias, além de proporcionar proteção contra infecções e alergias e estimular o sistema imunológico. Por essa razão as nutrizes são incentivadas a ordenhar e doar o excesso de leite produzido, ficando os bancos de leite humano responsáveis pela atividade de coleta, processamento e controle de qualidade de colostro e leite humano, para posterior distribuição. Um dos métodos para o controle de qualidade do leite humano é o crematócrito, um micrométodo rápido através do qual se determina a quantidade de creme e se estima a concentração de gordura e o seu conteúdo energético. Entretanto este método tem sido questionado pelos profissionais da área quanto a sua confiabilidade. Muitas mães, por razões médicas, metabólicas ou econômicas dependem de fórmulas artificiais para alimentar seus filhos. Entre os componentes nutricionais, os lipídios do leite humano são essenciais para o desenvolvimento de recém-nascidos. Portanto, a composição dos ácidos graxos e a sua distribuição na cadeia dos triacilgliceróis devem ser alvos de estudos em fórmulas infantis. Muitos trabalhos detalham as características químicas do lipídio do leite humano, mas pouco se conhece quanto às propriedades físicas desta gordura. Este trabalho teve por objetivo comparar o conteúdo energético estimado pelo método do crematócrito e o calculado a partir da composição centesimal das amostras de leite humano, além disso, caracterizar o lipídio do leite humano e de um sucedâneo comercial (Betapol) quanto a sua composição química e propriedades físicas. As amostras de leite foram analisadas quanto crematócrito e teores de umidade, gordura, proteína, cinzas e carboidratos. O lipídio do leite humano e seu sucedâneo foram submetidos às análises de acidez, composição em ácidos graxos, índices de iodo, pontos de fusão e amolecimento, consistência, e análises microscópicas sob luz polarizada. Os resultados permitiram concluir que os valores energéticos do leite humano estimados pelo crematócrito e calculados pela composição centesimal não apresentaram correlação significativa, questionando a utilização deste método em bancos de leite. A gordura do leite humano e o Betapol apresentaram propriedades físico-químicas distintas. 


\subsection{INTRODUÇÃO}

O leite humano é o único alimento energético, nutricional e imunológico consumido em quantidades suficientes pelos recém-nascidos (ALMEIDA, 1999; NOBREGA \& CAMPOS, 1996). O aleitamento materno fortalece a imunidade, mantém o crescimento e desenvolvimento normal, melhora o processo digestivo no sistema gastro-intestinal, favorece o vínculo mãe-filho e facilita o desenvolvimento emocional, cognitivo e do sistema nervoso (NOBREGA \& CAMPOS, 1996; ANDERSON et al., 1999; UAUY \& MENA, 2001).

O leite humano contém de 3 a $5 \%$ de lipídios, dentre os quais $98 \%$ são de triacilgliceróis, $1 \%$ de fosfolipídios e $0,5 \%$ de esteróis (JENSEN, 1998). Os lipídios se apresentam na forma de glóbulos de cerca de $4 \mu \mathrm{m}$ de diâmetro em emulsão do tipo óleo em água, que é estabilizada por uma membrana contendo fosfolipídios e proteínas (CHRISTIE, 1995). Cerca de $50 \%$ do valor calórico total do leite humano é proveniente da gordura, que é fonte de colesterol, ácidos graxos essenciais e vitaminas lipossolúveis (INNIS et al., 1994). O conteúdo de ácidos graxos insaturados do leite humano é maior que o de leite de vaca (SILVA et al.., 2005).

As proteínas do leite humano são qualitativamente diferentes das do leite de vaca. Do conteúdo protéico do leite humano, $80 \%$ é lactoalbumina, enquanto que no leite de vaca essa proporção é de caseína. A relação proteínas do soro/caseína do leite humano é aproximadamente $80 / 20$, enquanto a do leite bovino é $20 / 80$. A baixa concentração de caseína no leite humano resulta na formação de coalho gástrico mais leve, com flóculos de mais fácil digestão e com reduzido tempo de esvaziamento gástrico. O leite humano contém também, diferentemente do leite de vaca, maiores concentrações de aminoácidos essenciais de alto valor biológico (cistina e taurina) que são fundamentais ao desenvolvimento do sistema nervoso central. Isso é particularmente importante para o prematuro, que não consegue sintetizá-los a partir de outros aminoácidos por deficiência enzimática (AMAMENTAÇÃO ONLINE, 2006).

A partir da década de 1970, com o incentivo ao aleitamento materno, houve crescimento na pesquisa sobre o leite humano (WRIGHT et al., 2000). Assim, as nutrizes foram incentivadas a ordenhar e doar o excesso de leite produzido, ficando os bancos de leite humano responsáveis pela atividade de coleta, processamento e 
controle de qualidade de colostro e leite humano, para posterior distribuição (GIBBS, et al., 1977).

O leite humano ordenhado contém, aproximadamente, $40 \mathrm{~g}$ de gordura/L e $700 \mathrm{kcal} / \mathrm{L}$. Um dos métodos para o controle de qualidade do leite humano é o crematócrito, um micrométodo rápido através do qual se determina a quantidade de creme e se estima a concentração de gordura e o conteúdo energético de uma amostra de leite humano (CAVALCANTE et al., 2005). O método de LUCAS et al. (1978) é o mais utilizado, sendo recomendado pela Rede Nacional de Bancos de Leite.

Mesmo com todo o esforço, os bancos de leite ainda utilizam fórmulas infantis para suplementação da alimentação de recém-nascidos. As fórmulas infantis disponíveis no mercado utilizam em sua composição fontes lipídicas de origem vegetal que têm a estrutura de triacilgliceróis diferente da gordura do leite humano, levando a perdas na absorção de nutrientes. Como as gorduras disponíveis na natureza não possuem tal estrutura, a alternativa seria a utilização de gorduras modificadas por interesterificação.

A empresa Loders \& Croklaan comercializa um sucedâneo do gordura do leite humano que tem o nome comercial BETAPOL ${ }^{\mathrm{TM}}$ e se baseia na modificação enzimática de tripalmitoilglicerol e óleo de girassol (QUILAN \& MOORE, 1993). SHIMADA et al. (2000) sintetizaram 1,3-araquidonoil-2-palmitoil-glicerol pela acidólise da estearina de palma com ácido araquidônico usando a lípase sn-1,3 específica de Rhizopus delemar. No Japão, AKIMMOTO et al. (1999) patentearam um método enzimático similar para produzir sucedâneo do gordura do leite humano rico em ácidos graxos poliinsaturados. CHRISTENSEN \& HOLMER (1993), utilizando a enzima sn-1,3 específica de Rhizomucor miehei, conduziram a produção de lipídios estruturados a partir da manteiga obtendo gordura semelhante à do leite humano quanto à composição de ácidos graxos e à sua posição na cadeia dos triacilgliceróis. Os ácidos graxos saturados do leite humano constituem cerca de $40 \%$, sendo predominante o ácido palmítico. Dentre os insaturados, o oléico e o linoléico estão presentes em maior quantidade. Contudo, pouco se conhece sobre as propriedades físicas da gordura do leite humano. Este trabalho teve por objetivo analisar a composição centesimal de amostras de leite humano e comparar o valor energético estimado pelo método de crematócrito com o calculado a partir da 
composição centesimal. Também teve por finalidade caracterizar a gordura do leite humano e um sucedâneo da gordura do leite humano, quanto à composição química e propriedades físicas. 


\subsection{MATERIAL E MÉTODOS}

\subsubsection{Amostras}

As atividades referentes à pesquisa com leite humano e a sua manipulação foram aprovadas pelos Comitês de Ética em Pesquisa com Seres Humanos do Hospital Universitário (HU/USP) e da Faculdade de Ciências Farmacêuticas (FCF/USP).

Foram utilizadas amostras de leite materno provenientes de 32 mães em diferentes estágios de lactação, sendo que 19 estavam na fase de colostro e 13 no estágio de leite maduro. As amostras foram doadas pelo Banco de Leite do Hospital Universitário USP-SP.

O leite foi pasteurizado (62,5 ํㅡ por 30 minutos) e armazenado sob congelamento.

Para a análise das propriedades físicas, a fase gordurosa foi separada de $20 \mathrm{~L}$ de leite em diferentes fases de lactação, utilizando centrífuga contínua de pratos cônicos Alfa-Laval, obtendo-se o creme de leite (emulsão óleo em água). Este, por sua vez, foi transformado em emulsão água em óleo utilizando batedeira planetária. $A$ fase gordurosa da emulsão água em óleo foi separada por fusão à temperatura de 70 ${ }^{\circ} \mathrm{C}$, seguida por decantação e filtração em papel de filtro. A gordura assim obtida foi armazenada sob congelamento.

O produto Betapol foi gentilmente doado pela empresa Loders Croklaan, divisão de Lipid Nutrition (Holanda).

\subsubsection{Métodos}

Os teores de lipídios, umidade, cinzas e proteína foram obtidos pela utilização da metodologia do Instituto Adolfo Lutz (IAL, 1985), em triplicata. Os carboidratos foram determinados por diferença.

A gordura obtida a partir do leite humano foi analisada quanto à acidez (IAL, 1985); índice de iodo, calculado a partir da composição em ácidos graxos (método AOCS Cd 1c-85, 1990); diâmetro e número dos cristais, por microscopia sob luz 
polarizada (SIMÕES \& GIOIELLI, 1999; SIMÕES \& GIOIELLI, 2000; SOTEROSOLIS \& GIOIELLI, 2001; GIOIELLI et al.,2003); pontos de fusão e amolecimento (métodos AOCS Cc 1-25 e Cc 3-25, 1990); consistência (DÍAZ GAMBOA \& GIOIELLI, 2003); conteúdo de gordura sólida (método AOCS Cd 16-81, 1990). A preparação de ésteres metílicos de ácidos graxos foi realizada seguindo a metodologia de HARTMAN \& LAGO (1973). A determinação da composição em ácidos graxos foi realizada em cromatógrafo a gás Varian GC, modelo $3400 \mathrm{CX}$ nas condições descritas por DÍAZ GAMBOA \& GIOIELLI (2003).

A análise de crematócrito foi realizada pelo Hospital Universitário da USP, segundo a metodologia indicada pela Rede Nacional de Bancos de Leite (LUCAS et al., 1978). O método do crematócrito consiste na centrifugação do leite humano por 15 min para a separação do creme e do soro do leite. O creme ocupa a parte posterior do capilar e corresponde à fração de coloração mais densa. O soro, de aspecto menos viscoso, fica abaixo do creme. Com auxílio de uma régua milimetrada mede-se o comprimento da coluna de creme $(\mathrm{mm})$ e da coluna total do produto (coluna de creme + coluna de soro, expressos em $\mathrm{mm}$ ). De posse destes valores, empregando as fórmulas abaixo, obtém-se:

Teor de creme $(\%)=$ coluna de creme $(\mathrm{mm}) \times 100$ coluna total de produto $(\mathrm{mm})$

Teor de gordura $=$ teor de creme $(\%)-0,59$ 1,46

Energia $(\mathrm{kcal} / \mathrm{L})=66,8 \times$ teor de creme $(\%)+290$ 


\subsection{RESULTADOS E DISCUSSÃO}

\subsubsection{Composição Centesimal}

A composição média observada para o leite humano nos estágios de colostro e maduro é apresentada na Tabela 3. Os valores obtidos para proteína e carboidratos estão próximos aos citados na literatura (VIEIRA et al., 2004; BORTOLOZO et al., 2004). Entretanto, a média dos teores lipídicos das amostras apresentaram-se abaixo do esperado. Os valores encontrados na literatura indicam teores superiores a 3\% de lipídios totais (CAVALCANTE et al., 2005; VIEIRA et al., 2004). Esta diminuição pode ter ocorrido devido ao complexo processo: préestocagem, congelamento, descongelamento, pasteurização, novo congelamento, novo descongelamento e aquecimento a qual o leite foi submetido. Durante todo esse processo são verificadas perdas energéticas significativas, principalmente no teor de gordura, principal fonte calórico-energética do leite humano. Os processos de congelamento e descongelamento, por sua vez, acarretam rompimento das membranas dos glóbulos de gordura, propiciando sua coalescência e facilitando sua aderência às paredes dos frascos armazenadores (CAVALCANTE et al., 2005; WANG et al., 1999). Assim, o crematócrito medido nas amostras descongeladas pode resultar em baixos valores de lipídios, provavelmente devido à lipólise do leite humano (WANG et al., 1999).

Tabela 3. Composição centesimal média de colostro e leite humano maduro.

\begin{tabular}{cccc}
\hline Colostro $(\mathrm{n}=19)$ & $\begin{array}{c}\text { Média } \pm \text { desvio } \\
\text { padrão } \\
(\%)\end{array}$ & Leite maduro $(\mathrm{n}=13)$ & $\begin{array}{c}\text { Média } \pm \text { desvio } \\
\text { padrão } \\
\end{array}$ \\
Umidade & $87,82 \pm 1,09$ & Umidade & $89,85 \pm 0,73$ \\
Carboidratos & $7,80 \pm 0,57$ & Carboidratos & $7,50 \pm 0,66$ \\
Proteínas & $1,85 \pm 0,71$ & Proteínas & $1,12 \pm 0,28$ \\
Lipídios & $1,84 \pm 0,43$ & Lipídios & $1,38 \pm 0,60$ \\
Cinzas & $0,30 \pm 0,16$ & Cinzas & $0,24 \pm 0,09$
\end{tabular}


O desvio padrão do valor energético das amostras a partir do crematócrito foi maior do que a partir da composição centesimal (Tabela 4). A faixa de valor energético estimada pelo crematócrito variou de 40,5 a $97,2 \mathrm{kcal} / 100 \mathrm{~g}$ para o colostro, e de 42,1 a $84,6 \mathrm{kcal} / 100 \mathrm{~g}$ para o leite maduro. Por outro lado, o valor energético calculado a partir da composição centesimal variou de 44,8 a 73,1 $\mathrm{kcal} / 100 \mathrm{~g}$ para o colostro e de 39,6 a 59,8 kcal/100g para o leite maduro.

Os valores de energia calculados pelo método do crematócrito e a partir da composição centesimal foram correlacionados separadamente (colostro e maduro). Os resultados mostraram que os valores energéticos estimados pelos dois métodos não apresentaram correlação significativa, embora outros trabalhos da literatura indiquem o contrário (LUCAS et al., 1978; WANG et al., 1999; COLLARES et al., 1997).

Por outro lado, a correlação linear entre o valor energético estimado pelo crematócrito e o teor lipídico obtido na composição centesimal foi significativa, sendo que $\circ R^{2}$ foi de 0,57 para o colostro e de 0,75 para o leite maduro. Esta alta correlação também foi encontrada por WANG et al. (1999) e MEIER et al. (2002).

As médias dos valores energéticos estimados pelo crematócrito e calculadas a partir da composição centesimal (Tabela 4) estiveram bem próximas para o colostro, e coerentes com os valores citados por BORTOLOZO et al. (2004), que encontraram média de $57,36 \pm 8,37 \mathrm{kcal} / 100 \mathrm{~g}$, e por $\mathrm{HOSOl}$ et al. (2005), que obtiveram média de $57,1 \pm 8 \mathrm{kcal} / 100 \mathrm{~g}$.

Contrariando a literatura (GOLDFARB \& SAVADONE, 1991; HAMOSH \& BITMAM, 1992; BLANC, 1981), neste trabalho foram obtidos maiores valores energéticos no colostro que no leite maduro (Tabela 4), embora os resultados possam ser considerados estatisticamente iguais em função do alto desvio padrão.

Os lipídios são os componentes mais variáveis na composição do leite humano e sua quantidade pode variar em função do período de lactação (colostro e maduro), do período da mamada (diurno ou noturno) e ao longo de cada mamada (leite do início e do fim) (JENSEN, 1998). 
Tabela 4. Média dos valores energéticos estimados pelo crematócrito e calculados pela composição centesimal.

\begin{tabular}{cccc}
\hline Colostro $(\mathrm{n}=19)$ & $\begin{array}{c}\text { Valor energético } \\
\text { médio } \pm \text { desvio } \\
\text { padrão }(\mathrm{kcal} / 100 \mathrm{~g})\end{array}$ & $\begin{array}{c}\text { Veite maduro energético } \\
(\mathrm{n}=13)\end{array}$ & $\begin{array}{c}\text { médio } \pm \text { desvio } \\
\text { padrão }(\mathrm{kcal} / 100 \mathrm{~g})\end{array}$ \\
\hline Crematócrito & $56,60 \pm 13,50$ & Crematócrito & $53,87 \pm 12,52$ \\
Composição & $56,69 \pm 6,30$ & Composição & $46,70 \pm 5,63$ \\
centesimal & & centesimal & \\
\hline
\end{tabular}

\subsubsection{Propriedades físico-químicas da gordura do leite humano e do Betapol}

A acidez da gordura do leite humano apresentou valor relativamente alto, de 2,84 g ácido oléico/100 g amostra, embora não tenham sido encontrados na literatura dados correspondentes. O tempo entre a coleta das amostras, manipulação e armazenamento são fatores que possivelmente acarretam danos hidrolíticos na mesma, causados possivelmente pela ação de lipases que estão naturalmente presentes no leite humano (JENSEN, 1998). O BetapolTM apresentou acidez de $0,05 \mathrm{~g}$ ácido oléico/100 g, valor coerente com as especificações do produto.

Os valores encontrados para a composição em ácidos graxos por cromatografia gasosa (Tabela 5) estão adequados às especificações fornecidas pelo fabricante do Betapol. Em relação ao leite humano, a composição em ácidos graxos se situou na faixa encontrada pela literatura (BLANC, 1981; LIEN et al., 1997; CHRISTIE, 1982), com exceção dos ácidos oléico e linoléico. Mesmo sendo uma gordura exclusivamente vegetal, o Betapo| ${ }^{\mathrm{TM}}$ possui $52 \%$ de ácidos graxos saturados, sendo rica nos ácidos láurico, palmítico, oléico e linoléico. Por outro lado, a gordura do leite humano apresentou-se rica nos ácidos palmítico, oléico e linoléico, com $44 \%$ de ácidos graxos saturados. 
Tabela 5. Composição em ácidos graxos, acidez e índice de iodo do Betapol ${ }^{\mathrm{TM}}$ e da gordura do leite humano.

\begin{tabular}{ccc}
\hline Ácido graxo (\%) & Betapo|T $^{\mathrm{TM}}$ & Leite humano $^{\circ}$ \\
\hline $10: 0$ & 1,0 & 1,3 \\
$12: 0$ & 17,3 & 7,0 \\
$14: 0$ & 5,7 & 8,0 \\
$16: 0$ & 25,8 & 21,6 \\
$16: 1$ & - & 2,2 \\
$18: 0$ & 2,6 & 6,1 \\
$18: 1 \mathrm{n}-9$ & 35,1 & 27,7 \\
$18: 1 \mathrm{n}-9 \mathrm{t}$ & - & 4,1 \\
$18: 2 \mathrm{n}-6$ & 11,2 & 19,1 \\
$18: 3 \mathrm{n}-3$ & 1,2 & 1,2 \\
$20: 2$ & - & 0,9 \\
$20: 4 \mathrm{n}-6$ & - & 0,6 \\
Acidez (g ácido oléico/100g) & 0,05 & 2,84 \\
Índice de lodo (g iodo/100g) & 53 & 60 \\
\hline
\end{tabular}

As médias obtidas para os pontos de fusão e amolecimento da gordura do leite humano foram de 34,8 e $31,5^{\circ} \mathrm{C}$, respectivamente, e encontram-se próximos ao valor descrito pela literatura, que é de $32^{\circ} \mathrm{C}$ (BLANC, 1981). As médias para os pontos de fusão e amolecimento do Betapo|TM foram de 32,1 e $26,9^{\circ} \mathrm{C}$, respectivamente, sendo de 3 a $4 \stackrel{\circ}{\circ} \mathrm{C}$ abaixo dos valores da gordura do leite humano.

A Figura 3 apresenta a consistência das amostras em diversas temperaturas. $\mathrm{O}$ aumento de temperatura provocou queda brusca na consistência do Betapol ${ }^{\mathrm{TM}} \mathrm{e}$ do leite humano devido à fusão gradual dos cristais e conseqüente destruição da rede cristalina, que confere plasticidade à gordura. Assim, as amostras apresentaram-se mais plásticas a temperaturas entre 15 e $20^{\circ} \mathrm{C}$ (HAIGHTON, 1959). 


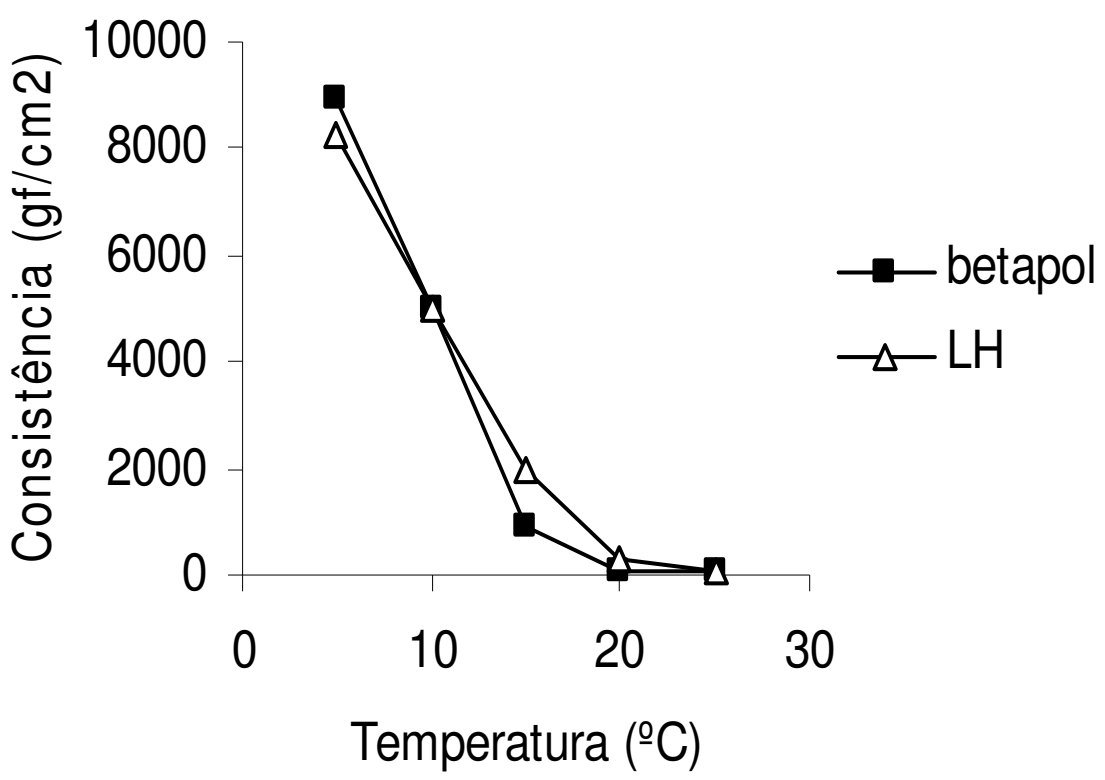

Figura 3. Consistência do Betapol e da gordura do leite humano.

O comportamento de consistência e conteúdo de gordura sólida (Figura 4) das amostras foi bastante semelhante. Em baixas temperaturas (5 e $10^{\circ} \mathrm{C}$ ) o Betapol apresentou-se como uma gordura mais consistente que a gordura do leite humano (Figura 3), o que foi confirmado pelo comportamento da curva de conteúdo de gordura sólida (Figura 4) Com o aumento da temperatura, o Betapol tornou-se uma gordura mais macia que a gordura do leite humano, tendo o conteúdo de gordura sólida acompanhado esse mesmo comportamento. 


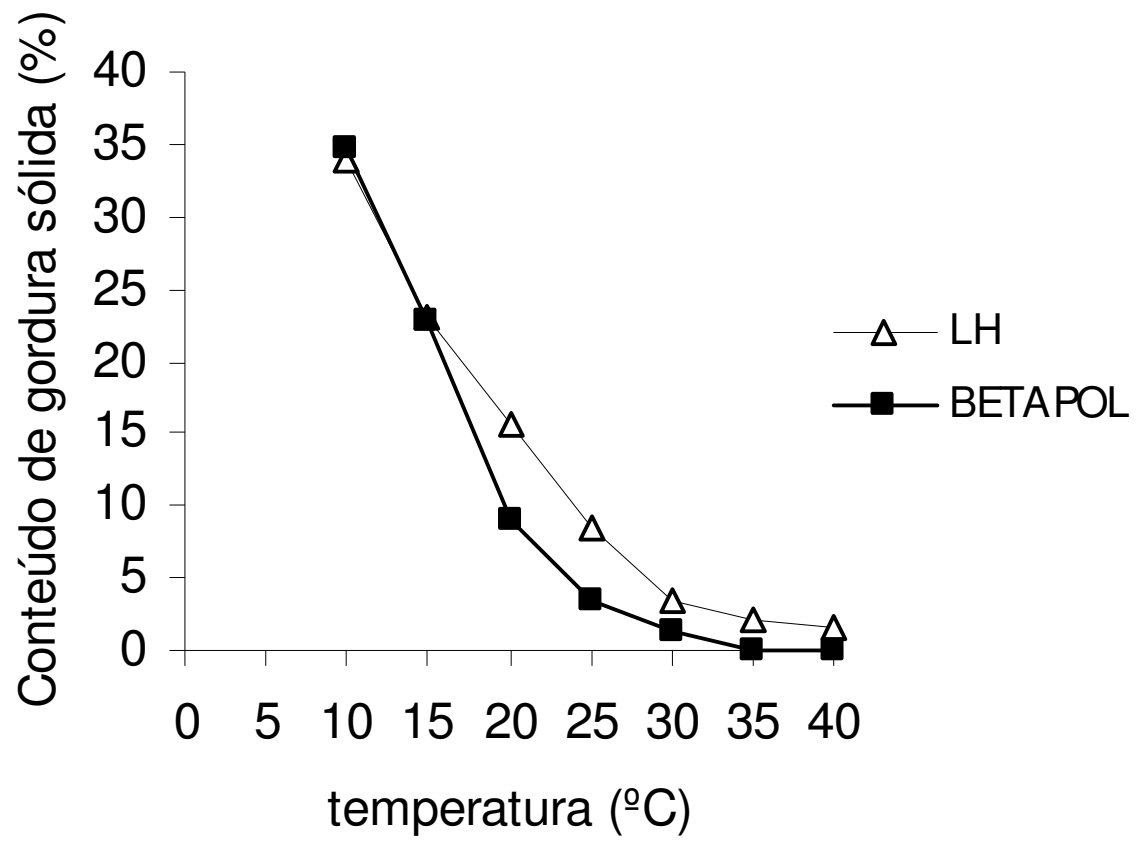

Figura 4. Conteúdo de gordura sólida do Betapol e da gordura do leite humano.

O conteúdo de gordura sólida e a consistência apresentaram alta correlação, tanto para a gordura do leite humano como para o Betapol, com $R^{2}$ de 0,97 e 0,98, respectivamente.

Quando o conteúdo de gordura sólida é baixo, ao redor de 3 a $5 \%$, a consistência é igual a zero. Isto mostra que quando o teor de sólidos na gordura é muito baixo, o material apresenta-se como um líquido viscoso, ao invés de se comportar como uma gordura plástica. Quando a proporção de gordura no estado sólido é maior que cerca de $5 \%$, o óleo líquido é imobilizado pela matriz cristalina, tornando a gordura plástica (LARSSON, 1994; SILVA \& GIOIELLI, 2006).

A Tabela 6 apresenta o diâmetro médio e o número de cristais observados por microscopia sob luz polarizada. Como a velocidade de nucleação aumenta exponencialmente com o aumento da supersaturação, enquanto a velocidade de crescimento dos cristais aumenta linearmente com a supersaturação, o número de cristais aumenta e o tamanho dos cristais diminui quando a cristalização ocorre a baixas temperaturas, o que pode ser observado na Tabela 6 (SIMÕES \& GIOIELLI, 1999a; TIMMS, 1995) 
Tabela 6. Diâmetro médio e número dos cristais da gordura do leite humano e do BetapolTM.

\begin{tabular}{lcccccc}
\hline & \multicolumn{3}{c}{ Gordura do leite humano } & \multicolumn{3}{c}{ BetapolTM $^{\mathrm{TM}}$} \\
\hline & $15^{\circ} \mathrm{C}$ & $20^{\circ} \mathrm{C}$ & $25^{\circ} \mathrm{C}$ & $15^{\circ} \mathrm{C}$ & $20^{\circ} \mathrm{C}$ & $25^{\circ} \mathrm{C}$ \\
\hline Diâmetro médio $(\mu \mathrm{m})$ & 6,3 & 62,1 & 256,0 & 12,4 & 119,2 & 189,0 \\
Numero de cristais & 5496 & 248 & 14 & 1049 & 76 & 6 \\
\hline
\end{tabular}

A Figura 5 apresenta a estrutura cristalina das amostras, por cristalização lenta na faixa de temperatura de 15 a $25^{\circ} \mathrm{C}$. O leite humano e o Betapo ${ }^{\mathrm{TM}}$ apresentaram cristalização homogênea e granular a $15^{\circ} \mathrm{C}$. O aumento da temperatura produziu aglomerados de cristais a $20^{\circ} \mathrm{C}$, com a formação de esferulitos mais organizados a $25^{\circ} \mathrm{C}$. Estes esferulitos podem ser classificados como do tipo A, pois apresentam cristais com núcleo compacto, cercados de agulhas longas e finas, distribuidas radialmente (SIMÕES \& GIOIELLI, 1999a). Para a gordura do leite humano, os esferulitos podem corresponder à forma polimórfica $\beta$, pois o alto nível de ácido palmítico na posição sn-2 da gordura do leite (LIEN et al., 1997; SILVA \& GIOIELLI, 2006; MARTIN et al., 1993) torna os triacilgliceróis com estrutura molecular homogênena. Por outro lado, os esferulitos do Betapol mostraram-se opticamente ativos (axial crosses), que possivelmente representam cristalização na forma polimórfica $\beta$-prima, pois o produto Betapol apresenta alto teor de ácido láurico, o que torna os triacilgliceróis com estrutura molecular mais heterogênea. 
Betapol
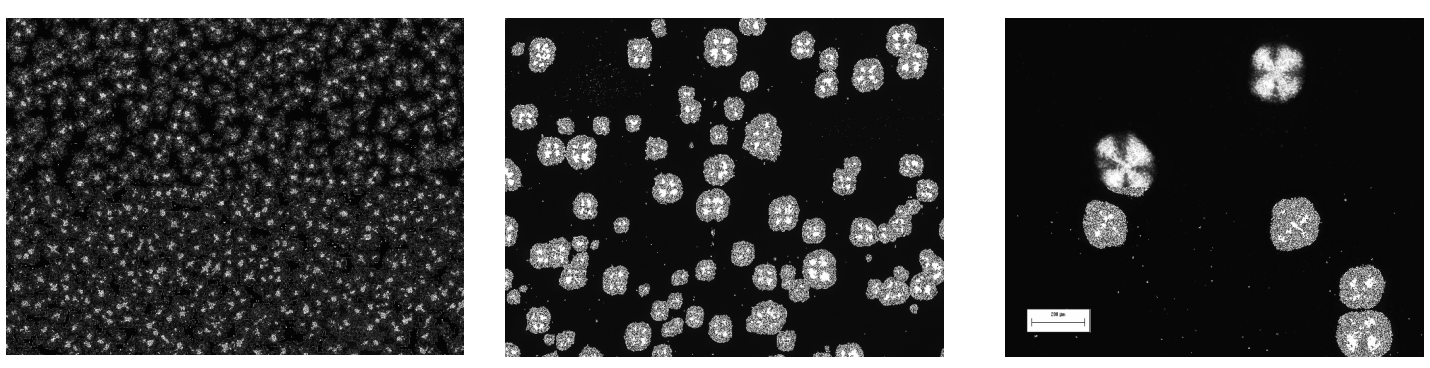

Gordura do leite humano
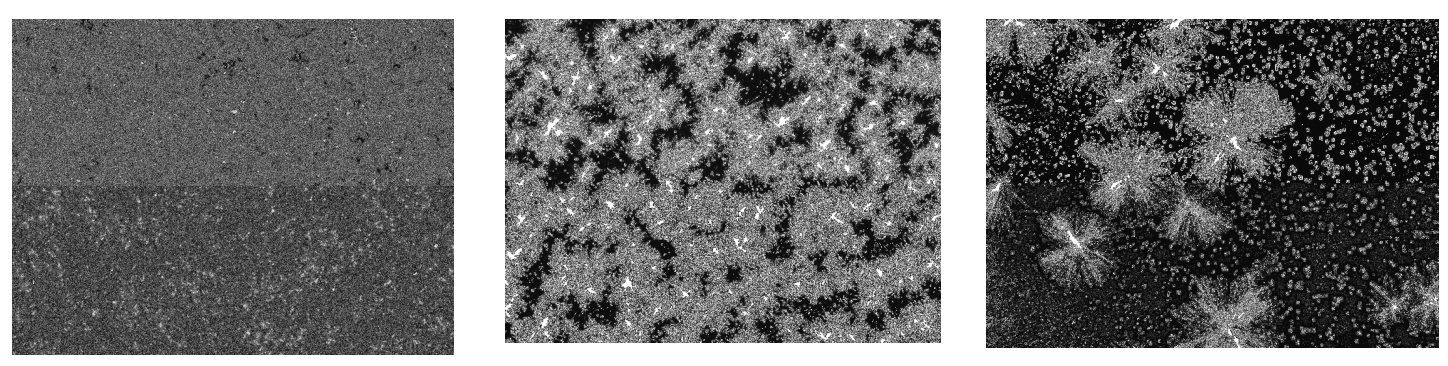

$15^{\circ} \mathrm{C}$

$20^{\circ} \mathrm{C}$

$25^{\circ} \mathrm{C}$

Figura 5. Estrutura cristalina da gordura do leite humano e do Betapol ${ }^{\mathrm{TM}}$. A barra representa $250 \mu \mathrm{m}$. 


\subsection{CONCLUSÕES}

Os valores de energia calculados pelo método do crematócrito e a partir da composição centesimal não apresentaram correlação significativa. Por outro lado, a correlação entre o valor energético estimado pelo crematócrito e o teor lipídico foi significativa.

O Betapol apresentou menor consistência, conteúdo de gordura sólida e pontos de fusão e amolecimento que a gordura do leite humano. Os comportamentos de cristalização também foram diferentes. 


\subsection{REFERÊNCIAS BIBLIOGRÁFICAS}

AKIMMOTO, K.; YAMAGUCHI, T.; FUJIKAWA, S. Novel triglyceride and composition comprising the same. EP Pat. 0965578 A1, 1999.

AMAMENTAÇÃO ONLINE. Manual de Amamentação. Composição do Leite Materno: colostro, leite anterior, posterior, comparações. Nosso Pequemo Manual de Amamentação: Composição do leite materno. Disponível em: http://www.aleitamento.org.br/manual/composi.htm. Acesso em: 10 mar. 2006

ALMEIDA, J.A.G. Amamentação: um híbrido natureza-cultura. Rio de Janeiro: Ed. Fiocruz. 1999. 120p.

AMERICAN OIL CHEMISTS' SOCIETY Official methods and recommended practices of the AOCS. 4.ed. Champaign, 1990.

ANDERSON, J.W.; JOHNSTONE, B.M.; RAMLEY, D.T. Breast-feeding and cognitive development: a meta-analysis. American Journal of Clinical Nutrition. v.70, n.4, p.525-535, 1999.

BLANC. B. Biochemical aspects of human milk--comparison with bovine milk. World review of nutrition and dietetics. v.36, n.1, p.1-89, 1981.

BORTOLOZO, E.A.F.; TIBONI, E.B.; CANDIDO L.M.B. Leite humano processado em bancos de leite para o recém-nascido de baixo peso: análise nutricional e proposta de um novo complemento. Revista Panamericana de Salud Pública. v.16, n.3, p.199-205, 2004.

CAVALCANTE, J.L.P.; TELLES, F.J.S.; PEIXOTO, M.M.L.V.; RODRIGUES, R.C.B. Uso de acidez titulável no controle de qualidade do leite humano ordenhado. Ciência e Tecnologia de Alimentos. v.25, n.1, 103-108, 2005.

CHRISTENSEN, T.C.; HOLMER, G. Lipase catalysed acyl-exchage reactions of butter oil. Synthesis of a human milk fat substitute for infant formulas. Milchwissenschaft - Milk Science International. v.48, n.10, p.543-547, 1993.

CHRISTIE, W.W. Composition and structure of milk lipids. In FOX, P.F., ed., Advanced dairy chemistry - 2 Lipids, Chapman \& Hall, London, p.1-36, 1995.

CHRISTIE, W. W.; CLAPPERTON, J.L. Structures of the triglycerides of cows' milk, fortified milks (including infant formulae), and human milk. Journal of Science Dairy Technology. v.35, n.1, p.22-24, 1982.

COLLARES, F.P.; GONÇALVES, C.V.; FERREIRA, J.S. Creamatocrit as a rapid method to estimate the contents of total milk lipids. Food Chemistry. v.60, n.4, p.465-467, 1997. 
DÍAZ GAMBOA, O.W.; GIOIELLI, L.A. Lípidos estructurados obtenidos por interesterificación química y enzimática a partir de aceite de pescado y grasa de semilla de palma. Grasas y Aceites, v.54, n.2, p.161-168, 2003

GIBBS, J.H.; FISHER, C.; BHATTACHARYA, S.; GODDARD, P; BAUM, J.D. Drip breast milk: its composition, collection and pasteurization. Early Human Development., v.1, p.227-245, 1997.

GIOIELLI, L.A.; SIMÕES, I.S.; RODRIGUES, J.N. Crystal morphology and interactions of binary and ternary mixtures of hydrogenated fats. Journal of Food Engineering. v.57, n.4, p.347-355, 2003.

GOLDFARB, M.F.; SAVADONE, M.S. Creamatocrit and pH measurements of human milk. Journal of Pediatric Gastroenterology and Nutrition. v.12, p.142-143, 1991.

HAIGHTON, A.J. The measurement of the hardness of margarine and fats with cone penetrometers. Journal of the American Oil Chemists' Society. v.36, n.8, p.345348,1959 .

HAMOSH, M.; BITMAN, J. Human milk in disease - Lipid composition. Lipids. v.27, n.11, p.848-857, 1992.

HARTMAN, L.; LAGO, R. C. A. Rapid preparation of fatty acid methyl esters from lipids. Laboratory Practices, v.22, p.475-494, 1973.

HOSOI, S.; KAZUHIRO, H.; DAIMATSU, T.; KIYOKAWA, M.; AIKAWA, T.; WATANABE, S. Lower energy content of human milk than calculated using conversion factors. Pediatric International. v.47, n.3, p.7-9, 2005.

INNIS, S.M.; DYER, R.; NELSON, C.M. Evidence that palmitic acid is absorbed as $s n-2$ monoacylglycerol from human milk by breast-fed infants. Lipids. v.29, n.8, 1994.

INSTITUTO ADOLFO LUTZ Normas Analíticas do Instituto Adolfo Lutz. 3.ed. São Paulo, 1985. v.1, p.245-266.

JENSEN, R.G. Human milk lipids as a model for infant formulas. Lipid Technology, v.3, p.34-38, 1998.

LARSSON, K. Lipids: Molecular organization, physical functions and technical applications, The Oil Press; Dundee, 1994, p.7.

LIEN, E.L; BOYLE, F.G.; YUHAS, R.; TOMARELLI, R.M.; QUINLAN, P. The effect of triglyceride positional distribuition on fatty acid absortion in rats. Journal of Pediatric Gastroenterology and Nutrition. v.25, n.2, p.167-174, 1997.

LUCAS, A.; GIBBS, J.A.H.; CYSTER, R.L.J.; BAUN, J.D. Creamatocrit: simple clinical technique for estimating fat concentration and energy value of human milk. British. Medicine Journal. v.1, n.11, p.1018-1020, 1978. 
MARTIN, J.C.; BOUGNOUX, P.; ANTONIE, J.M.; LANSON, M.; COUET, C. Triacylglycerols structure of human colostrum and mature milk. Lipids. v.28, n.7, p. $637-643,1993$.

MEIER, P.P.; ENGSTROM, J.L.; MURTAUGH, M.A.; VASAN, U.; MEIER, W.A.; SHANLER, R.J. Mothers' Milk Feedings in the Neonatal Intensive Care Unit: Accuracy of the Creamatocrit Technique. Journal of Perinatology. v.22, n.8, 646649, 2002.

NOBREGA, F.J.; CAMPOS, A.L.R. Distúrbios nutricionais e fraco vínculo mãe/filho. Rio de Janeiro: Revinter, 1996. 236p.

QUILAN, P.; MOORE, S. Modification of triglycerides by lipases: process technology and its application to the production of nutritionally improved fats. INFORM. v.4, n.5, p.580-585, 1993.

SHIMADA, Y.; NAGAO, T.; HAMASAKI, Y.; AKIMOTO, K.; SUGIHARA, A.; FUJIKAWA, S.; KOMEMUSHI, S.; TOMINAGA, Y. Enzymatic synthesis of structured lipid containing arachidonic and palmitic acids. Journal of the American Oil Chemists' Society. v.77, n.1, p.89-93, 2000.

SILVA, M.H.L.; SILVA, M.T.C.; BRANDÃO, S.C.C.; GOMES, J.C.; PETERNELLI, L.A.; FRANCESCHINI, S.C.C. Fatty acid composition of mature breast milk in Brazilian women. Food Chemistry. v.93, n.2, p.297-303, 2005.

SILVA, R.C.; GIOIELLI, L.A. Propriedades físicas de lipídios estruturados obtidos a partir de banha e óleo de soja. Revista Brasileira de Ciências Farmacêuticas. v.42, n.2, p.223-235, 2006.

SIMÕES, I.S.; GIOIELLI, L.A. Crystal morphology of binary and ternary mixtures of hydrogenated fats and soybean oil. Brazilian Archives of Biology and Technology., v.43, n.5, p.241-248, 2000.

SIMÕES, I.S.; GIOIELLI, L.A. Cristalização e polimorfismo de gorduras. Óleos Grãos, v.8, n.50, p.20-29, 1999.

SIMÕES, I.S.; GIOIELLI, L.A. Microscopia da cristalização parcial de gorduras hidrogenadas e óleo de soja. Revista Brasileira de Ciências Farmacêuticas. v.35,p.259-266, 1999a

SOTERO-SOLIS, V.E.; GIOIELLI, L.A. Estrutura cristalina de las grasas hidrogenadas del aceite de castaña de Brasil (Bertholletia Excelsa). Alimentaria, v.38, n.322, p.131-137, 2001.

TIMMS, R.E. Em Developments in oils and fats: HAMILTON, R.J., ed. Blackie London, 1995, 204p.

UAUY, R.; MENA, P. Lipids and neurodevelopment. Nutrition Reviews. v.59, suppl.1, p.34-48, 2001. 
VIEIRA, A.A.; MOREIRA, M.E.L.; ROCHA, A.D.; PIMENTA, H.P.; LUCENA, S.L. Análise do conteúdo energético do leite humano administrado a recém-nascidos de muito baixo peso ao nascimento. Journal de Pediatria. v.80, n.6, p.490-494, 2004.

WANG, C.D.; CHU, P.S.; MELLEN, B.G.; SHENAI, J.P. Creamatocrit and the Nutrient Composition of Human Milk. Journal of Perinatology. v.19, n.5, p.343346. 1999.

WRIGHT, A.J.; HARTEL, R.W.; NARINE, S.S.; MARANGONI, A.G. The effect of minor components on milk fat cristallization. Journal of the American Oil Chemists' Society. v.77, n.5, p.463-475, 2000 


\section{Propriedades físicas das misturas e dos}

lipídios estruturados obtidos a partir de banha e óleo de soja por interesterificação química

SILVA, R.C.; GIOIELLI, L.A. Propriedades físicas de lipídios estruturados obtidos a partir de banha e óleo de soja. Revista Brasileira de Ciências Farmacêuticas. v.42, n.2, p.223-235, 2006. 


\section{RESUMO}

Os lipídios do leite humano são essenciais para o desenvolvimento de recémnascidos. A composição dos ácidos graxos e a sua distribuição nas cadeias dos triacilgliceróis devem ser alvos de estudos em fórmulas infantis. Este trabalho pretende obter lipídios estruturados que possuam características semelhantes às da gordura do leite humano. Misturas binárias de banha e óleo de soja formuladas em diferentes proporções $(80: 20,60: 40,50: 50,40: 60,20: 80)$ foram submetidas à reação de interesterificação química. A composição em ácidos graxos, índice de iodo, conteúdo de gordura sólida, consistência e ponto de fusão foram analisados nas misturas antes e após a interesterificação. A adição de óleo de soja provocou decréscimo no conteúdo de gordura sólida e consistência da banha. A interesterificação química alterou o comportamento destas propriedades na banha e suas misturas binárias com o óleo de soja, em todas as proporções, possivelmente em função do aumento de triacilgliceróis di e trissaturados produzidos pela randomização. As interações entre banha e óleo de soja apresentaram efeito monotético, antes e após a interesterificação química. Dentre as misturas modificadas, as que continham banha com 20 e $40 \%$ de óleo de soja foram as que mais se aproximaram da composição em ácidos graxos dos lipídios do leite humano. 


\subsection{INTRODUÇÃO}

A maioria dos óleos vegetais em seu estado natural tem aplicações limitadas devido a sua composição química específica. Para ampliar sua utilização, os óleos vegetais são modificados quimicamente, pela hidrogenação ou interesterificação, ou fisicamente pelo fracionamento (PETRAUSKAITE et al., 1999). A interesterificação é atualmente o processo mais importante para a modificação físico-química de óleos e gorduras (NOOR LIDA et al., 2002). Como a interesterificação ao acaso provoca modificações nas propriedades dos óleos e gorduras naturais, isto significa que a distribuição original dos ácidos graxos nos triacilgliceróis não é ao acaso. Óleos e gorduras são interesterificados quimicamente na presença de um catalisador inorgânico, como metóxido de sódio (GIOIELLI, 1998).

A interesterificação de misturas entre gorduras sólidas e óleos vegetais pode formar produtos com excelentes características (KARABULUT, 2004). O rearranjo ou a randomização dos ácidos graxos nos triacilgliceróis produz gorduras ou óleos com novas propriedades físicas (ZEITOUN et al., 1993). A interesterificação catalisada por via química ou por lipases é utilizada na indústria de óleos e gorduras para a fabricação de margarinas e "shortenings" (GIOIELLI, 2002; HUI, 1996).

Lipídios estruturados podem ser definidos como triacilgliceróis reestruturados ou modificados para alterar a composição em ácidos graxos e/ou sua distribuição nas moléculas de glicerol, por métodos químicos, enzimáticos ou de engenharia genética (LEE \& AKOH, 1998; OSBORN \& AKOH, 2002). Os lipidios estruturados são normalmente obtidos por interesterificação. Sob a perspectiva de custo e aplicação em larga escala, a interesterificação química parece ser o método mais atrativo (WILLIS \& MARANGONI, 1999).

Lipídios estruturados são normalmente misturas de triacilgliceróis modificadas para apresentar composição particular em ácidos graxos ou triacilgliceróis, a fim de obter alguma propriedade desejável, como o valor calórico reduzido ou o ponto de fusão alterado. Também podem apresentar características favoráveis quanto à resposta imune, síntese de eicosanóides e ações antiinflamatórias (AKOH \& MOUSSATA, 1998).

A banha é rica nos ácidos palmítico e oléico, na proporção aproximada de 1:2, que correspondem a cerca de $75 \%$ de seus ácidos graxos. Mais da metade dos 
triacilgliceróis é composta por esses dois ácidos graxos e, dentro de certos limites, a composição da gordura dos suínos pode ser influenciada pela sua dieta. Cerca de $30 \%$ do peso da carcaça é de gordura, podendo chegar a $50 \%$ em animais excessivamente gordos (O' BRIEN, 1998). Os avanços da indústria de produção animal trouxeram acréscimos nas quantidades de ácidos graxos poliinsaturados aos tecidos adiposos de suínos (GLÄSER et al., 2004).

A banha tende a cristalizar na forma $\beta$, embora tenha uma composição em ácidos graxos heterogênea, que provocaria a cristalização na forma $\beta$-prima. Contudo, pelo fato de apresentar alta proporção de ácido palmítico na posição sn-2, a composição em triacilgliceróis pode ser considerada homogênea, o que induz à cristalização na forma $\beta$. Contudo, a tendência de cristalização da banha pode ser modificada pela interesterificação química (O'BRIEN, 1998; ROUSSEAU et al., 1998). A plasticidade dos produtos formados na banha modificada são melhores devido ao maior número de cristais finos, levando a melhor aparência durante o armazenamento e melhores qualidades para a panificação (O'BRIEN, 1998).

O óleo de soja é obtido dos grãos da soja (Glycina máxima). É muito versátil, devido a vários fatores, tais como: alto conteúdo de ácidos graxos essenciais; desenvolve cristais grandes que são facilmente filtráveis quando o óleo é hidrogenado e fracionado; tem alto índice de iodo, que permite a sua hidrogenação produzindo grande variedade de gorduras plásticas; e seu refino tem baixas perdas (POUZET, 1996).

O leite humano contém de 3 a $5 \%$ de lipídios, dentre os quais $98 \%$ são triacilgliceróis, $1 \%$ fosfolipídios e $0,5 \%$ esteróis (JENSEN, 1986). Os triacilgliceróis são compostos principalmente por ácidos graxos de cadeia longa (cerca de $90 \%$ dos ácidos graxos no leite humano). A composição em ácidos graxos dos lipídios no leite humano varia de acordo com alguns fatores, como: dieta, estágio de lactação, estação do ano e condições individuais da lactante (CHRISTIE, 1995; JENSEN, 1998; CLARK \& HUNDRIESER, 1993). A dieta de gorduras nos primeiros anos de vida tem sido extensivamente investigada devido às associações ao desenvolvimento cerebral (AGOSTONI, 2003).

O ácido palmítico representa $20-25 \%$ dos ácidos graxos do leite humano e cerca de $70 \%$ é esterificado na posição sn-2 dos triacilgliceróis (MARTIN et al, 1993; LIEN et al., 1997). Esta estrutura no leite humano é importante porque são os 
triacilgliceróis que ficam expostos às enzimas lipolíticas, e não os ácidos graxos (De FOUW et al., 1994; LIEN, 1994; LUCAS et al., 1997; SUMMERS et al., 1998). As lípases pancreática e gástrica hidrolisam seletivamente os ácidos graxos nas posições sn-1,3, produzindo ácidos graxos livres e monoacilgliceróis na posição sn2. O 2-palmitoilglicerol é mais eficientemente absorvido que o ácido palmítico na forma livre, que forma sabões insolúveis com o cálcio e o magnésio (INNIS et al. 1994; FORSYNTH, 1998).

A distribuição estereoespecífica do ácido palmítico na posição sn-2 é considerada como o principal motivo para a melhor absorção das gorduras do leite humano (JENSEN, 1998). Fórmulas artificiais contendo o ácido palmítico esterificado na posição sn-2 também apresentaram melhor desempenho comparadas às que possuíam o ácido palmítico na posição sn-1,3 (CARNIELLI et al., 1995; JENSEN, 1998).

O objetivo deste trabalho foi estudar os efeitos da interesterificação química nas propriedades físicas de banha e suas misturas binárias com o óleo soja, procurando desenvolver lipídios estruturados sucedâneos do gordura do leite humano. 


\subsection{MATERIAL E MÉTODOS}

\subsubsection{Matéria Prima}

Foram utilizados gordura suína (banha) e óleo de soja, ambos obtidos no comércio local.

\subsubsection{Mistura}

Para o estudo das interações em misturas binárias de gordura e óleo foi realizado um planejamento de 7 experimentos (Tabela 7). A banha e óleo de soja são representados por $x_{1}$ e $x_{2}$, respectivamente, sendo que $x_{1}+x_{2}=1$ ou $100 \%$. Duas amostras representam os componentes isoladamente e cinco foram formadas por misturas binárias. As amostras foram preparadas por mistura nas proporções mencionadas, após fusão completa à temperatura de $60-70^{\circ} \mathrm{C}$ e novamente solidificadas, sendo armazenadas sob resfriamento.

Os resultados referentes às misturas e às reações de interesterificação foram analisados estatisticamente por regressão múltipla, representada pela seguinte equação:

$$
Y=\beta_{1} x_{1}+\beta_{2} X_{2}+\beta_{12} X_{1} x_{2}
$$

onde: $Y=$ reposta;

$\beta=$ coeficientes gerados por regressão múltipla;

$X=$ proporção do componente.

Foi evidenciada a significância das interações entre os componentes e as alterações decorrentes dos rearranjos (DÍAZ GAMBOA \& GIOIELLI, 2003a, 2003b). 
Tabela 7. Planejamento experimental das misturas.

\begin{tabular}{ccc}
\hline Amostra $\left(\mathrm{n}^{\mathrm{o}}\right)$ & \multicolumn{2}{c}{ Proporção $(\mathrm{p} / \mathrm{p})$} \\
\cline { 2 - 3 } & Banha & Óleo de soja \\
\hline 1 & 100 & 0 \\
2 & 80 & 20 \\
3 & 60 & 40 \\
4 & 50 & 50 \\
5 & 40 & 60 \\
6 & 20 & 80 \\
7 & 0 & 100 \\
\hline
\end{tabular}

\subsubsection{Interesterificação química}

Foram interesterificados $250 \mathrm{~g}$ de amostra, previamente seca em balão de vidro, sob pressão reduzida, acoplado a um rotaevaporador em banho de água a aproximadamente $95^{\circ} \mathrm{C}$. A essa porção foram misturados $0,5 \%(\mathrm{~m} / \mathrm{m})$ de catalisador metóxido de sódio (Merck). A reação de interesterificação foi realizada sob agitação constante, sob pressão reduzida, a $65-70^{\circ} \mathrm{C}$ em balão de três bocas imerso em banho de água, por 1 hora. Para interromper a reação foi adicionada água destilada. Para minimizar o escurecimento decorrente da reação e para reter a umidade foram adicionados sílica em pó e sulfato de sódio anidro, respectivamente. Os produtos foram filtrados a quente utilizando-se papel de filtro (DIAZ GAMBOA \& GIOIELLI, 2003a, 2003b; RODRIGUES \& GIOIELLI, 2003).

\subsubsection{Conteúdo de gordura sólida}

O conteúdo de gordura sólida, analisado por ressonância magnética nuclear, utilizando aparelho Maran Ultra Bench Top NMR de $20 \mathrm{MHz}$, foi determinado segundo as normas da "American Oil Chemists' Society" (1990), método Cd 16-81. 


\subsubsection{Consistência}

As amostras de gordura foram aquecidas à temperatura de $60-70 \stackrel{\circ}{\circ} \mathrm{em}$ forno de microondas para a completa fusão dos cristais, sendo acondicionadas em béqueres de $250 \mathrm{~mL}$. O condicionamento foi efetuado por 24 horas em geladeira comum $\left(5-8^{\circ} \mathrm{C}\right)$ e em seguida por 24 horas em estufa com temperatura controlada (temperatura de análise $\pm 0,5 \stackrel{\circ}{\circ}$ ).

A análise de consistência foi efetuada através de teste de penetração com cone acrílico de ângulo 45을 em analisador de textura TA-XT2 (Stable Micro Systems), controlado por microcomputador (DÍAZ GAMBOA \& GIOIELLI, 2003a, 2003b).

Os testes foram conduzidos nas seguintes condições: determinação da força em compressão; distância: 10,0 mm; velocidade: 2,0 mm/s; tempo: $5 \mathrm{~s}$; triplicata: em três pontos diferentes para cada amostra.

Para realizar a conversão dos dados de penetração em um parâmetro independente do peso e do tipo de cone, foi utilizada a equação proposta por Haighton (1959), para o cálculo do "yield value":

$$
\mathrm{C}=\mathrm{K} \cdot \mathrm{W} / \mathrm{p}^{1,6}
$$

\section{Onde:}

$C=$ "yield value", em $\mathrm{gf} / \mathrm{cm}^{2}$

$\mathrm{K}=$ fator que depende do ângulo do cone (para ângulo de $45^{\circ}$, $\mathrm{K}$ é igual a 4700)

$\mathrm{W}=$ peso total do sistema, em $\mathrm{g}$ (para penetrômetro de cone)

$\mathrm{p}=$ profundidade de penetração

Considerando as condições dos testes de compressão realizados com o analisador de textura, a equação assume a seguinte forma:

$$
C=4700 . \mathrm{W} / 100^{1,6}
$$

Onde:

$\mathrm{C}=$ "yield value", em gf $/ \mathrm{cm}^{2}$

$\mathrm{W}=$ força em compressão, em g, para tempo $=5 \mathrm{~s}$. 


\subsubsection{Preparação de ésteres metílicos de ácidos graxos}

Os ésteres metílicos de ácidos graxos foram obtidos pela saponificação de 150-200 mg de cada amostra com $3,5 \mathrm{~mL}$ de solução metanólica $0,5 \mathrm{~N}$ de hidróxido de potássio, sob refluxo por 3-5 min em banho de água a 75-80 ำ. À solução quente foram adicionados $10,5 \mathrm{~mL}$ do reagente de esterificação. A mistura foi refluxada por cerca de 3 min e transferida para funil de separação, adicionando-se $20 \mathrm{~mL}$ de éter de petróleo e $40 \mathrm{~mL}$ de água destilada. A fase aquosa foi descartada e a fase orgânica lavada duas vezes com $20 \mathrm{~mL}$ de água destilada. As camadas aquosas foram também descartadas. A camada de éter de petróleo foi transferida para um tubo de ensaio com tampa. O solvente foi evaporado em banho-maria a 40 ${ }^{\circ} \mathrm{C}$ sob corrente de nitrogênio. Hexano foi adicionado como solvente para a realização das análises cromatográficas. As amostras foram armazenadas a $-20 \stackrel{\circ}{ } \mathrm{C}$ (HARTMAN \& LAGO, 1973).

\subsubsection{Composição em ácidos graxos}

A análise da composição em ácidos graxos foi realizada em cromatógrafo a gás Varian GC, modelo $3400 \mathrm{CX}$, equipado com detector de ionização de chama e "Workstation Star Chromatography". Foi utilizada coluna capilar de sílica fundida CP WAX 52 CB (Chrompack), com 30 metros de comprimento x 0,25 mm de diâmetro interno e contendo $0,25 \mu \mathrm{m}$ de polietilenoglicol dentro da coluna. As condições foram: injeção split, razão de 50:1; temperatura da coluna: $150 \stackrel{\circ}{\mathrm{C}}$ por $5 \mathrm{~min}$, programada até $215^{\circ} \mathrm{C}$ numa razão de $3^{\circ} \mathrm{C} / \mathrm{min}$; gás de arraste: hélio, numa vazão de 1,5 $\mathrm{mL} / \mathrm{min}$; gás make up: hélio a $30 \mathrm{~mL} /$ minuto; temperatura do injetor $250{ }^{\circ} \mathrm{C}$; temperatura do detector $280{ }^{\circ} \mathrm{C}$. A composição qualitativa foi determinada por comparação dos tempos de retenção dos picos com os respectivos padrões de ácidos graxos. A composição quantitativa foi realizada por normalização de área, sendo expressa como porcentagem em massa (DÍAZ GAMBOA \& GIOIELLI, 2003a).

O índice de iodo foi calculado a partir da composição em ácidos graxos, segundo as normas da "American Oil Chemists' Society" (1990), método Cd 1c-85. O resultado é expresso em $\mathrm{g}$ de iodo/100g de gordura. A equação utilizada foi a seguinte: 
índice de iodo $=(\%$ acido octadecenóico $\times$ 0,860 $)+(\%$ ácido octadecadienóico x 1,732) + (\% ácido octadecatrienóico x 2,616).

\subsubsection{Composição em triacilgliceróis}

A composição em triacilgliceróis das gorduras naturais puras foi obtida na literatura (HUI,1996; NEFF et al., 2002) e foram utilizadas para o cálculo de proporcionalidade das misturas. Nas misturas interesterificadas foi aplicada a teoria 1,2,3 random (HUI, 1996). Foram calculadas as porcentagens de triacilgliceróis triinsaturados, dissaturados-monoinsaturados, diinsaturados-monossaturados e triinsaturados.

\subsubsection{Ponto de fusão}

O ponto de fusão, utilizando tubo capilar fechado, foi determinado segundo as normas da “American Oil Chemists' Society (1990) método Cc 1-25. 


\subsection{RESULTADOS E DISCUSSÃO}

\subsubsection{Composição em ácidos graxos}

Os resultados obtidos a partir da cromatografia gasosa estão apresentados nas Tabelas 8 e 9. As gorduras foram analisadas em duplicata e as tabelas representam as médias obtidas.

As composições em ácidos graxos da banha e do óleo de soja obtidos estão de acordo com a literatura consultada (O'BRIEN, 1998; CODEX, 1999; ANVISA, 1999, DAVENEL et al., 1999; GLÄSER et al., 2004).

Tabela 8. Composição em ácidos graxos e índice de iodo da banha, do óleo de soja e suas misturas antes da interesterificação.

\begin{tabular}{cccccccc}
\hline \multicolumn{7}{c}{ Proporção de banha/óleo de soja (\% área) } \\
\hline Ácido & & & & & Óleo de \\
graxo & Banha & $80-20$ & $60-40$ & $50-50$ & $40-60$ & $20-80$ & Soja \\
\hline $14: 0$ & 2,15 & 1,30 & 1,11 & 0,99 & 0,85 & & - \\
$16: 0$ & 29,70 & 23,77 & 21,87 & 20,84 & 19,68 & 18,46 & 13,23 \\
$16: 1$ & 2,78 & 1,96 & 1,56 & 1,35 & 1,13 & 0,70 & - \\
$18: 0$ & 12,11 & 11,30 & 9,30 & 8,32 & 7,26 & 5,24 & 3,71 \\
$18: 1 n-9$ & 38,17 & 36,62 & 32,58 & 30,55 & 28,27 & 23,92 & 20,87 \\
$18: 1 n-9$ t & 2,52 & 2,38 & 2,14 & 2,02 & 1,87 & 1,51 & 1,23 \\
$18: 2$ n-6 & 12,58 & 21,40 & 29,45 & 33,53 & 37,48 & 43,97 & 54,21 \\
$18: 3 n-3$ & - & 1,24 & 2,00 & 2,39 & 3,12 & 4,27 & 6,53 \\
\hline I.I. & 54 & 72 & 84 & 90 & 97 & 108 & 129 \\
\hline
\end{tabular}

${ }^{1}$ I.I. - Índice de iodo.

A composição em ácidos graxos da banha varia de acordo com a raça, sexo, dieta e idade do animal. Sendo assim, o grau de saturação da banha depende principalmente da quantidade e da composição de gordura da dieta do suíno (O' BRIEN, 1998). Por essa razão o CODEX ALIMENTARIUS (1999) determina faixas amplas na composição dos ácidos graxos. 
Os ácidos graxos saturados da banha constituem cerca de $44 \%$, sendo predominantes os ácidos palmítico e esteárico (Tabela 8). A presença de um ácido graxo trans na banha (18:1 n-9t) também foi observada por GLÄSER et al. (2004), que atribuíram essa presença ao fornecimento de gordura vegetal hidrogenada nas rações.

A adição de óleo de soja na banha provocou redução no teor de ácidos graxos saturados e concomitante aumento no teor de ácidos poliinsaturados (Tabelas 8 e 9 ).

Tabela 9. Composição em ácidos graxos e índice de iodo da banha, do óleo de soja e suas misturas após a interesterificação.

\section{Proporção banha/óleo de soja (\% área)}

\begin{tabular}{lccccccc} 
Ácido & & & & & & & \\
graxo & Banha & $80-20$ & $60-40$ & $50-50$ & $40-60$ & $20-80$ & Óleo de Soja \\
$14: 0$ & 2,43 & 1,39 & 1,19 & 0,97 & 1,36 & 0,59 & - \\
$16: 0$ & 30,55 & 24,24 & 22,44 & 20,43 & 23,61 & 17,90 & 15,18 \\
$16: 1$ & 2,87 & 2,03 & 1,63 & 1,35 & 1,39 & 0,66 & - \\
$18: 0$ & 11,73 & 11,09 & 9,11 & 8,05 & 6,80 & 5,32 & 3,57 \\
$18: 1 \mathrm{n}-9$ & 37,70 & 36,11 & 31,19 & 29,72 & 26,93 & 24,00 & 20,67 \\
$18: 1 \mathrm{n}-9 \mathrm{t}$ & 2,28 & 2,39 & 2,15 & 1,96 & 1,60 & 1,43 & 1,21 \\
$18: 2 \mathrm{n}-6$ & 12,44 & 21,18 & 29,03 & 33,12 & 35,69 & 44,86 & 53,35 \\
$18: 3 \mathrm{n}-3$ & - & 1,20 & 2,00 & 1,65 & 2,62 & 4,37 & 6,06 \\
\hline I.I. $^{1}$ & 54 & 71 & 82 & 87 & 92 & 110 & 126
\end{tabular}

${ }^{1}$ I.I. - Índice de iodo

De acordo com O'BRIEN (1998), o índice de iodo da banha varia entre 46 e 70, enquanto para o CODEX ALIMENTARIUS (1999) esse valor varia de 55 a 65 . O índice de iodo do óleo de soja estabelecido pela legislação brasileira varia de 120 a 143 (BRASIL, 1999). Os resultados calculados para índice de iodo da banha e do óleo de soja situam-se nas faixas da literatura e da legislação brasileira. O índice de iodo das misturas é proporcional a quantidade de cada componente. 
Após a interesterificação química não ocorreram alterações significativas na composição em ácidos graxos e no índice de iodo (Tabela 9) da banha, do óleo de soja e de suas misturas binárias.

Dentre as misturas modificadas, as que continham 20 e $40 \%$ de óleo de soja foram as que mais se aproximaram da composição em ácidos graxos dos lipídios do leite humano.

\subsubsection{Composição em triacilgliceróis}

Os dados obtidos na literatura para banha (NEFF et al., 2002) e óleo de soja (HUI, 1996) são apresentados na Tabela 10, e foram utilizados para o cálculo de proporcionalidade das misturas. A banha natural possui em sua composição cerca de $38 \%$ de triacilgliceróis dissaturados $\left(\mathrm{S}_{2} \mathrm{l}\right)$ e trissaturados $\left(\mathrm{S}_{3}\right)$, enquanto o óleo de soja tem apenas ao redor de $6 \%$ destes triacilgliceróis. 
Tabela 10. Composição em triacilgliceróis da banha e suas misturas binárias com o óleo de soja antes e após a interesterificação química.

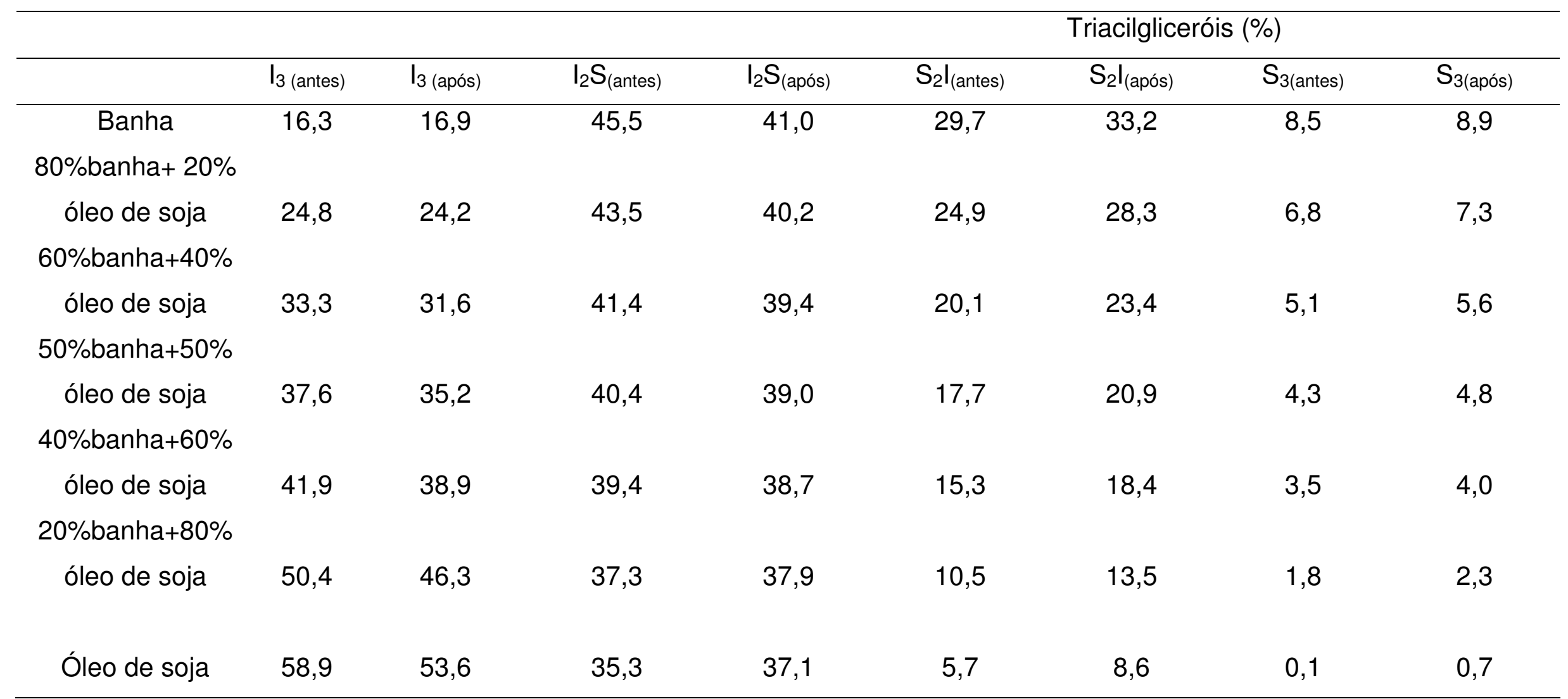

$\mathrm{I}_{3-}$ triinsaturados (III)

$\mathrm{I}_{2} \mathrm{~S}$ - monossaturados-diinsaturados (SII/IIS + ISI)

$\mathrm{S}_{2} \mathrm{I}$ - dissaturados-monoinsaturados (SSI/ISS + SIS)

$\mathrm{S}_{3}$ - trissaturados (SSS) 
A randomização química alterou a distribuição dos triacilgliceróis nas gorduras (Tabela 10). Tanto a banha como o óleo de soja apresentaram acréscimo de cerca de 4\% em triacilgliceróis di e trissaturados após a interesterificação.

\subsubsection{Ponto de fusão}

A Tabela 11 mostra os pontos de fusão das amostras antes e após a reação de interesterificação.

Tabela 11. Pontos de fusão da banha, do óleo de soja e de suas misturas binárias antes e após a interesterificação química.

\begin{tabular}{ccc}
\hline & \multicolumn{2}{c}{ Ponto de fusão $\left(^{\circ} \mathrm{C}\right)$} \\
\hline Mistura & Antes & Após \\
\hline Banha & 42,1 & 42,2 \\
80\%banha+20\% óleo de soja & 39,6 & 39,8 \\
60\%banha+40\% óleo de soja & 36,3 & 35,8 \\
50\%banha+50\% óleo de soja & 31,7 & 33,1 \\
40\%banha+60\% óleo de soja & 28,8 & 31,5 \\
20\%banha+80\% óleo de soja & 13,2 & 19,0 \\
Óleo de soja & $(-20)^{*}$ & 2 \\
\hline
\end{tabular}

* O'BRIEN, 1998

As propriedades funcionais das gorduras podem ser relacionadas aos triacilgliceróis componentes da fase gordurosa. Os trissaturados, com pontos de fusão de $54-65^{\circ} \mathrm{C}$, e alguns dissaturados, com pontos de fusão de $27-42^{\circ} \mathrm{C}$, são os responsáveis pela estrutura do produto. Estes últimos também são importantes para as propriedades orais próximo a temperatura corporal. Os monossaturados, com pontos de fusão $1-23^{\circ} \mathrm{C}$ são importantes para as propriedades orais e estão relacionados ao desempenho à temperatura ambiente. Os triinsaturados, com pontos de fusão -14 a $1^{\circ} \mathrm{C}$ são importantes para a maciez do produto, além de serem fatores nutricionais, contendo os ácidos graxos poliinsaturados (HOFFMANN, 1989). 
A Figura 6 mostra a relação entre 0 ponto de fusão e os teores de triacilgliceróis di e trissaturados. Observa-se que teores de di e trissaturados até $20 \%$ produzem aumentos significativos no ponto de fusão, sendo que a partir desta proporção os aumentos nos pontos de fusão foram menores.

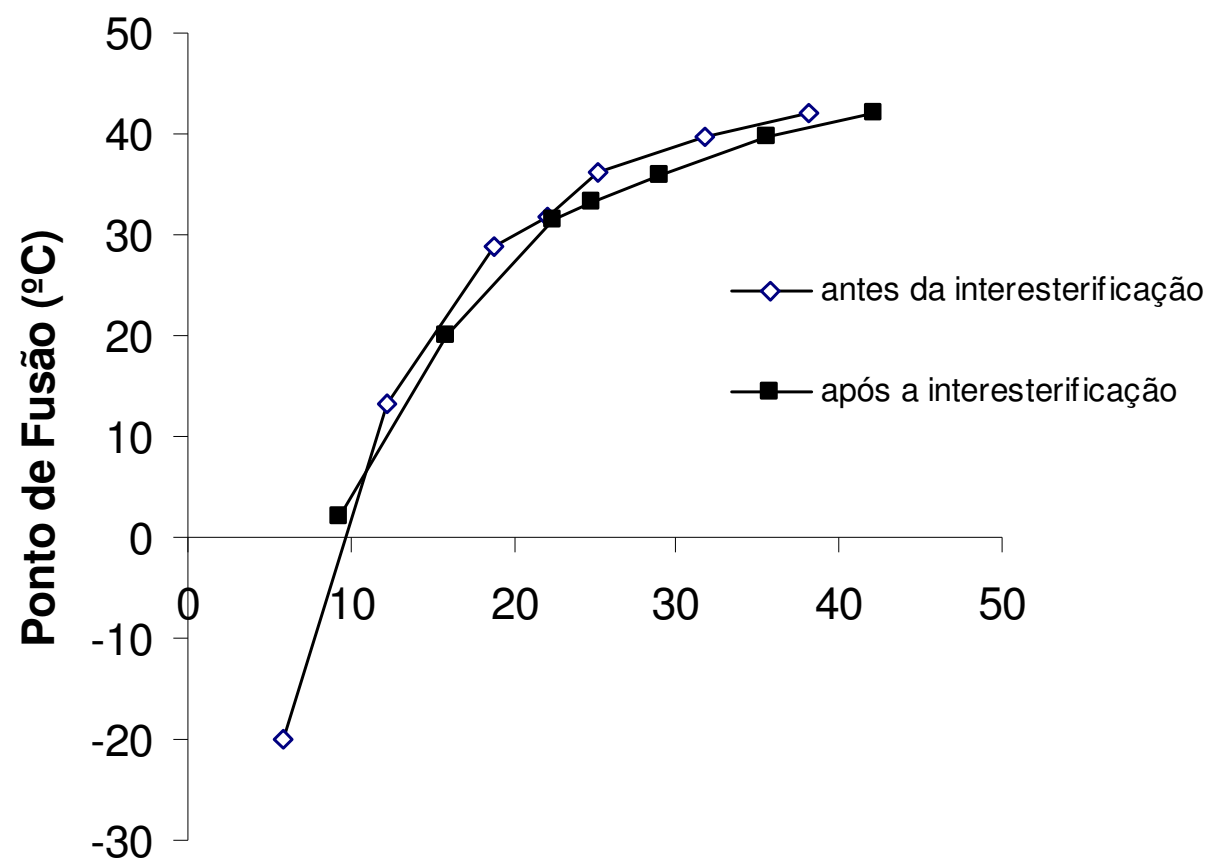

di e trissaturados (S2I +S3)

Figura 6. Correlação entre o ponto de fusão e a composição em triacilgliceróis di e trissaturados das gorduras.

O ponto de fusão dos lipídios do leite humano é de cerca de $35^{\circ} \mathrm{C}$ (FORSYNTH, 1998).YANG et al. (2003) obtiveram ponto de fusão semelhante ao dos lipídios do leite humano na produção de um sucedâneo produzido por interesterificação enzimática de banha e ácidos graxos da soja. Neste trabalho, as misturas interesterificadas contendo 40 e $50 \%$ de óleo de soja foram as que mais se aproximaram deste valor, com pontos de fusão de 35,8 e $33,1^{\circ} \mathrm{C}$, respectivamente.

\subsubsection{Conteúdo de gordura sólida}

Os resultados de conteúdo de gordura sólida das misturas antes da interesterificação estão representados na Figura 7. Observa-se que o aumento da 
temperatura provocou diminuição no conteúdo de gordura sólida devido à fusão gradativa das amostras. MARANGONI \& ROUSSEAU (1998b) encontraram o mesmo comportamento para misturas entre banha e óleo de canola. Segundo a literatura (DEMAN et al, 1991; MARANGONI \& ROUSSEAU,1998 ${ }^{\mathrm{b}}$; DAVENEL et al.,1999) a banha apresenta conteúdo de gordura sólida em torno de $20 \%$ a $25^{\circ} \mathrm{C}$, valor este próximo ao obtido neste trabalho.

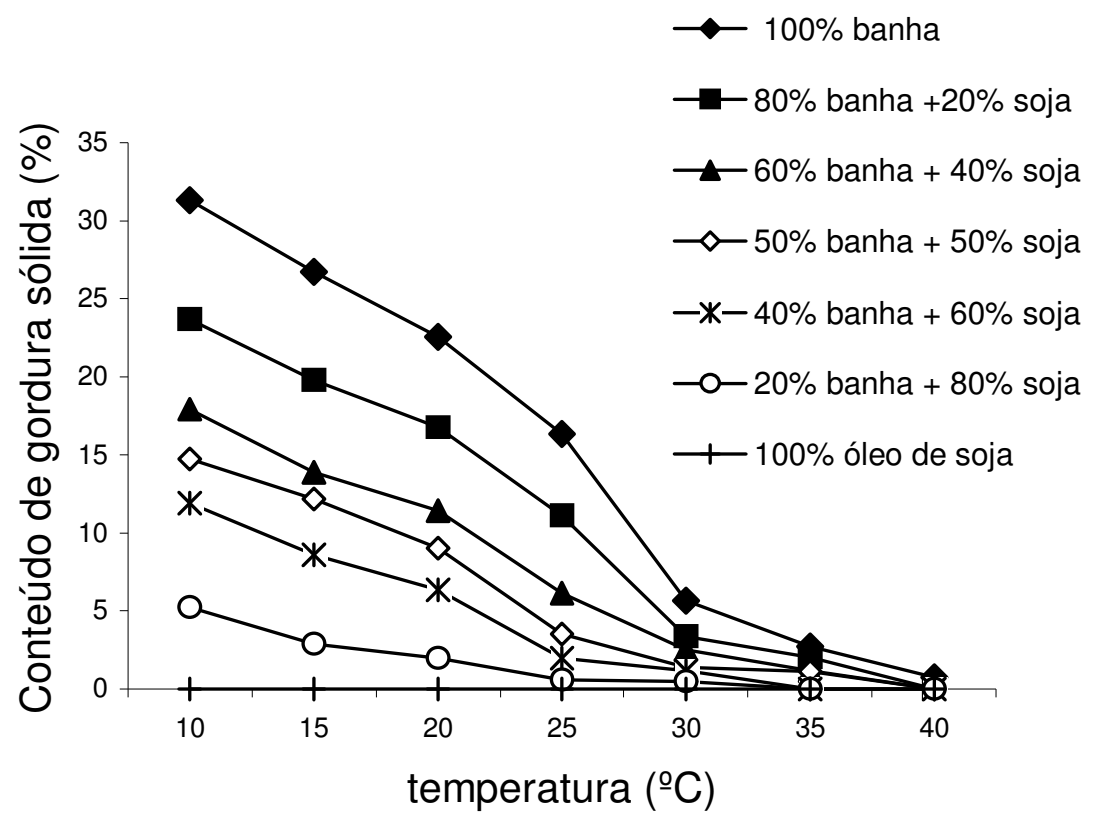

Figura 7. Conteúdo de gordura sólida da banha, do óleo de soja e das misturas binárias antes da interesterificação.

A Tabela 12 apresenta os coeficientes de regressão múltipla do tipo quadrático para as misturas antes da interesterificação. $O$ óleo de soja não apresentou influência significativa no conteúdo de gordura sólida. A interação entre os dois componentes foi significativa e negativa até a temperatura de $30^{\circ} \mathrm{C}$. Por se tratar de interação entre um componente sólido e um líquido, o efeito foi monotético, que é prevalente em sistemas que contém gorduras com diferentes pontos de fusão (KNOESTER et al., 1972) e indica o enfraquecimento da estrutura cristalina da banha pelo efeito da diluição com o óleo de soja. 
Tabela 12. Coeficientes calculados por regressão múltipla a partir dos resultados experimentais do conteúdo de gordura sólida antes da interesterificação química.

\begin{tabular}{ccccc}
\hline & \multicolumn{4}{c}{ Coeficientes } \\
\cline { 2 - 5 } Temperatura $\left({ }^{\circ} \mathrm{C}\right)$ & $\beta_{1}$ & $\beta_{2}$ & $\beta_{12}$ & $\mathrm{R}^{2}$ \\
\hline 10 & 31,05 & 0 & $-3,42$ & 0,99 \\
15 & 26,71 & 0 & $-7,70$ & 0,99 \\
20 & 22,76 & 0 & $-9,77$ & 0,99 \\
25 & 16,69 & 0 & $-17,59$ & 0,99 \\
30 & 5,51 & 0 & $-4,77$ & 0,99 \\
35 & 2,84 & 0 & 0 & 0,93 \\
40 & 0,61 & 0 & 0 & 0,78
\end{tabular}

$\beta_{1}$ - banha, $\beta_{2}$ - óleo de soja, $\beta_{12}$ - interação entre a banha e óleo de soja, $R^{2-}$ coeficiente de determinação

MARANGONI \& ROUSSEAU (1998a) observaram variação no conteúdo de gordura sólida devido a interesterificação química, que tornou as curvas de conteúdo de gordura sólida da banha e suas misturas com o óleo de canola menos lineares e mais próximas entre si. Segundo estes autores, o conteúdo de gordura sólida a 25ㄷ da banha interesterificada quimicamente foi reduzido de 20 para $10 \%$, valores muito próximos aos observados na Figura 8. 


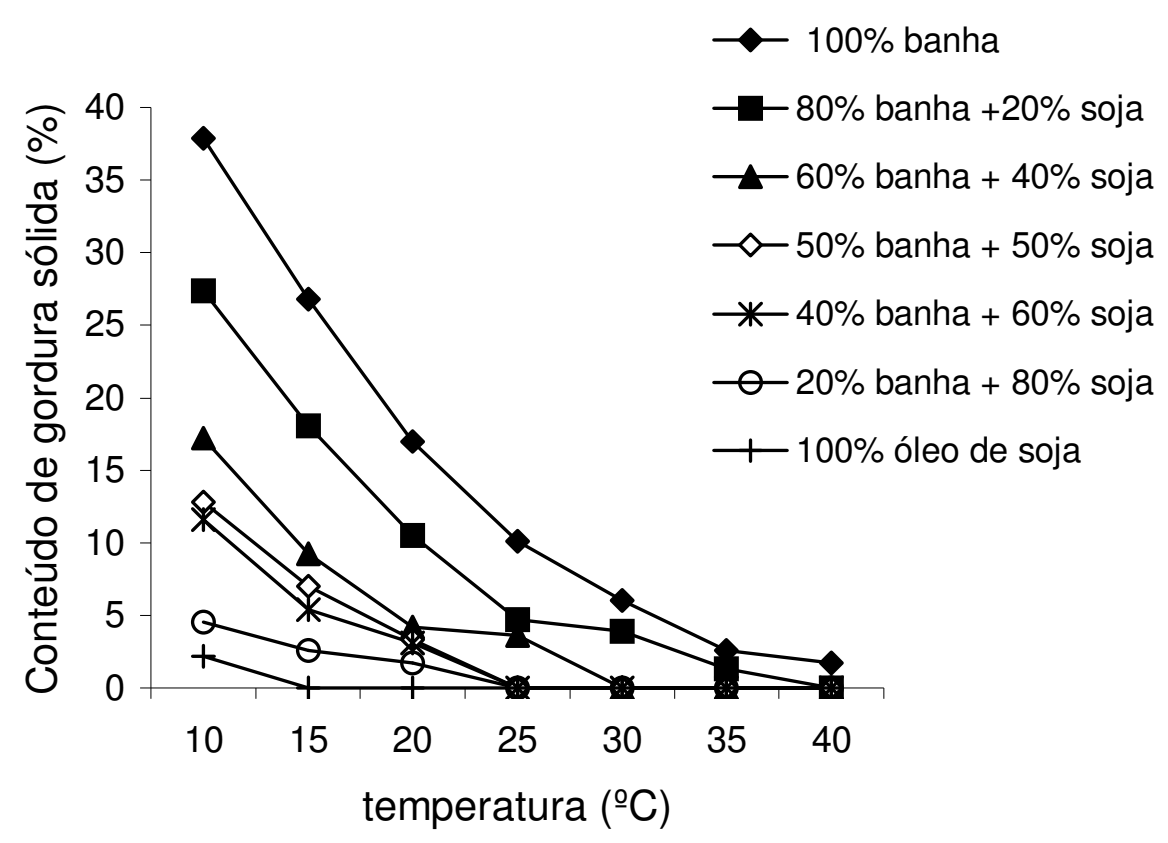

Figura 8. Conteúdo de gordura sólida da banha, do óleo de soja e das misturas binárias após a interesterificação química.

A Tabela 13 apresenta os coeficientes de regressão múltipla a partir dos resultados do conteúdo de gordura sólida para as misturas após a interesterificação. A interação entre os dois componentes foi significativa e negativa até a temperatura de $35^{\circ} \mathrm{C}$. Os valores dos coeficientes da interação são muito maiores nas amostras interesterificadas, indicando efeito monotético mais acentuado após rearranjo dos ácidos graxos nos triacilgliceróis.

Tabela 13. Coeficientes calculados por regressão múltipla a partir dos resultados experimentais do conteúdo de gordura sólida após a interesterificação química.

\begin{tabular}{|c|c|c|c|c|}
\hline \multirow[b]{2}{*}{ Temperatura $\left({ }^{\circ} \mathrm{C}\right)$} & \multicolumn{4}{|c|}{ Coeficientes } \\
\hline & $\beta_{1}$ & $\beta_{2}$ & $\beta_{12}$ & $\mathrm{R}^{2}$ \\
\hline 10 & 38,05 & 0 & $-25,44$ & 0,99 \\
\hline 15 & 26,81 & 0 & $-25,13$ & 0,99 \\
\hline 20 & 16,68 & 0 & $-19,87$ & 0,97 \\
\hline 25 & 9,93 & 0 & $-14,88$ & 0,92 \\
\hline 30 & 9,20 & 0 & $-12,06$ & 0,94 \\
\hline 35 & 2,56 & 0 & $-5,280$ & 0,96 \\
\hline 40 & 1,38 & 0 & 0 & 0,78 \\
\hline \multicolumn{5}{|c|}{$\beta_{1-}$ banha, $\beta_{2}$-óleo de soja, $\beta_{12 \text { - interação entre a banha e óleo de soja, } R^{2}}$} \\
\hline \multicolumn{5}{|c|}{ coeficiente de determinação } \\
\hline
\end{tabular}


GLÄSER et al. (2004) correlacionaram algumas propriedades físicas da gordura suína com a composição em ácidos graxos e encontraram alta correlação entre a proporção dos ácidos esteárico e linoléico e o conteúdo de gordura sólida a $20^{\circ} \mathrm{C}$.

As Figuras 9 e 10 apresentam as correlações entre o percentual de ácidos esteárico e linoléico e o conteúdo de gordura sólida a $20^{\circ} \mathrm{C}$ das gorduras e suas misturas. Observa-se que a diminuição nos teores de ácido esteárico causa redução no conteúdo de gordura sólida antes e após a interesterificação química (Figura 9).

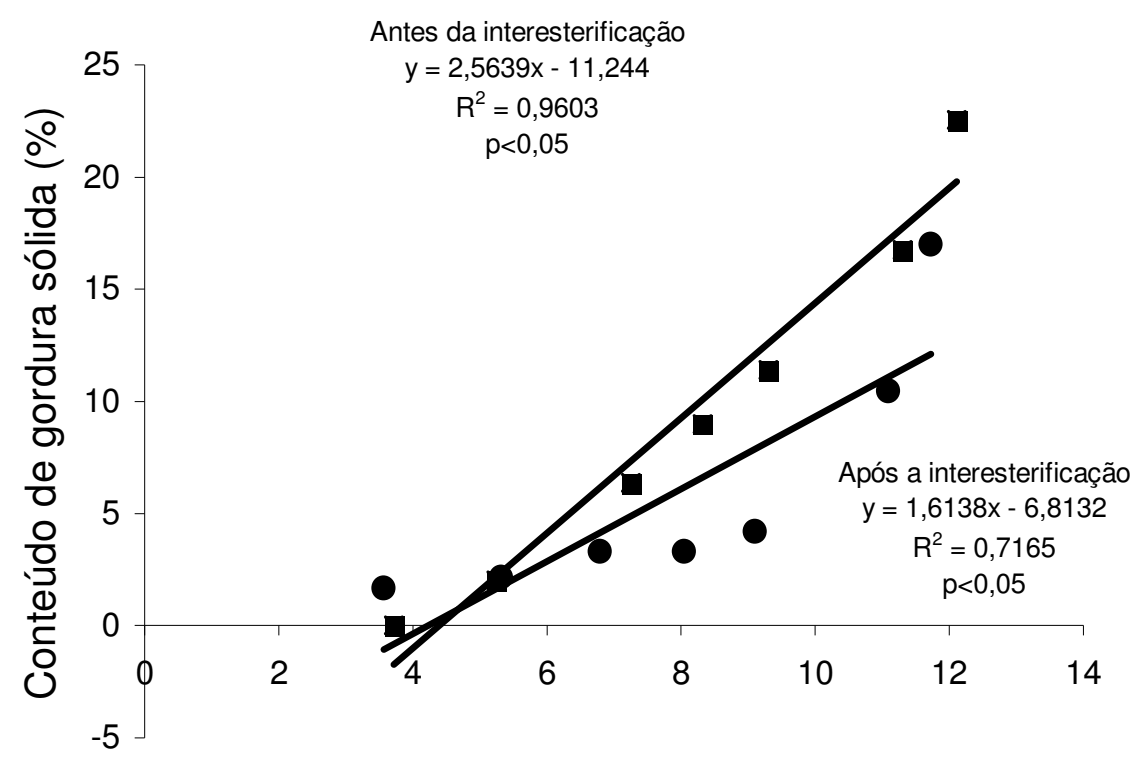

ácido esteárico (\%)

Figura 9. Correlação entre o percentual de ácido esteárico e o conteúdo de gordura sólida a $20^{\circ} \mathrm{C}$.

A regressão do tipo linear simples foi aplicada aos resultados, a $p<0,05$. A correlação entre a proporção de ácido linoléico e o conteúdo de gordura sólida é linear e inversa, ou seja, quanto maior a proporção deste ácido graxo menor é o conteúdo de gordura sólida (Figura 10). 


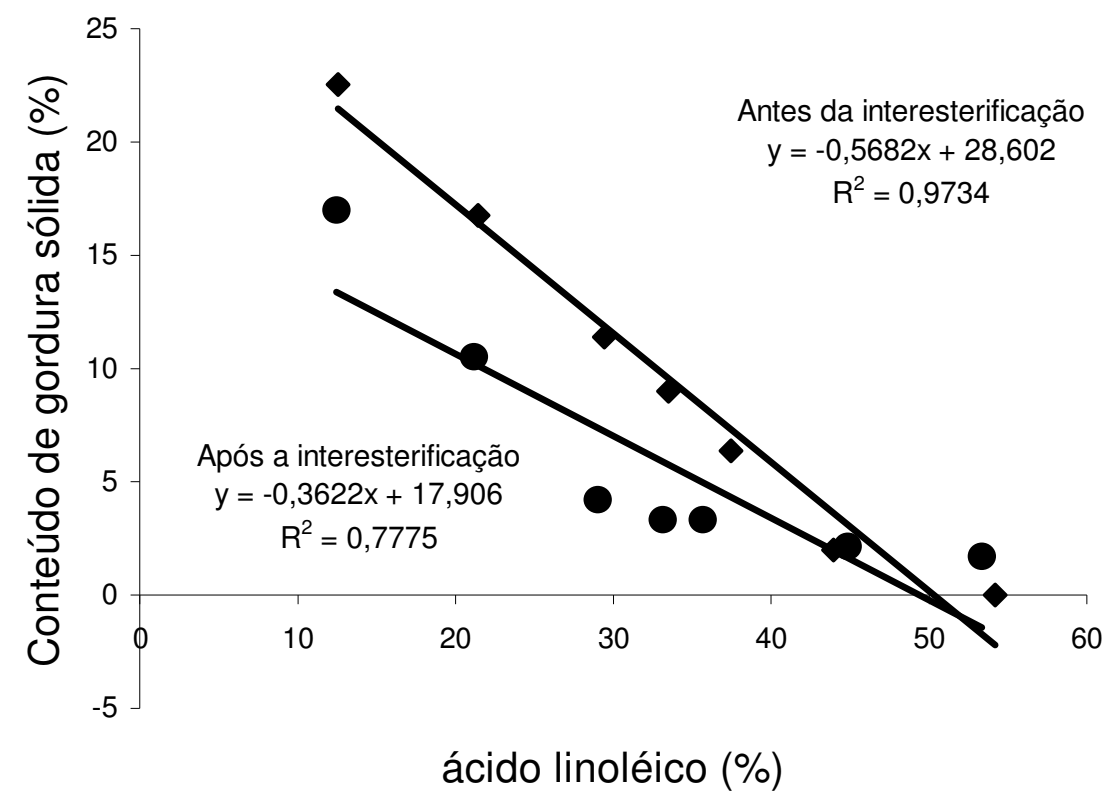

Figura 10. Correlação entre o percentual de ácido linoléico e o conteúdo de gordura sólida a $20^{\circ} \mathrm{C}$.

\subsubsection{Consistência}

A Figura 11 representa a propriedade de consistência das gorduras individuais e de suas misturas antes da interesterificação, calculadas como yield value em gf $/ \mathrm{cm}^{2}$ em temperaturas de 5 a $25^{\circ} \mathrm{C}$. Os resultados demonstraram que a adição do óleo de soja provocou diminuição na consistência de todas as misturas, pelo fato de ser um óleo líquido e assim provocar a diluição da rede cristalina da banha. Também pode-se observar que a consistência foi diminuída pelo aumento da temperatura, que provoca fusão gradual dos cristais e conseqüente destruição da rede cristalina, o que confere plasticidade à gordura (DEMAN, 1983). 


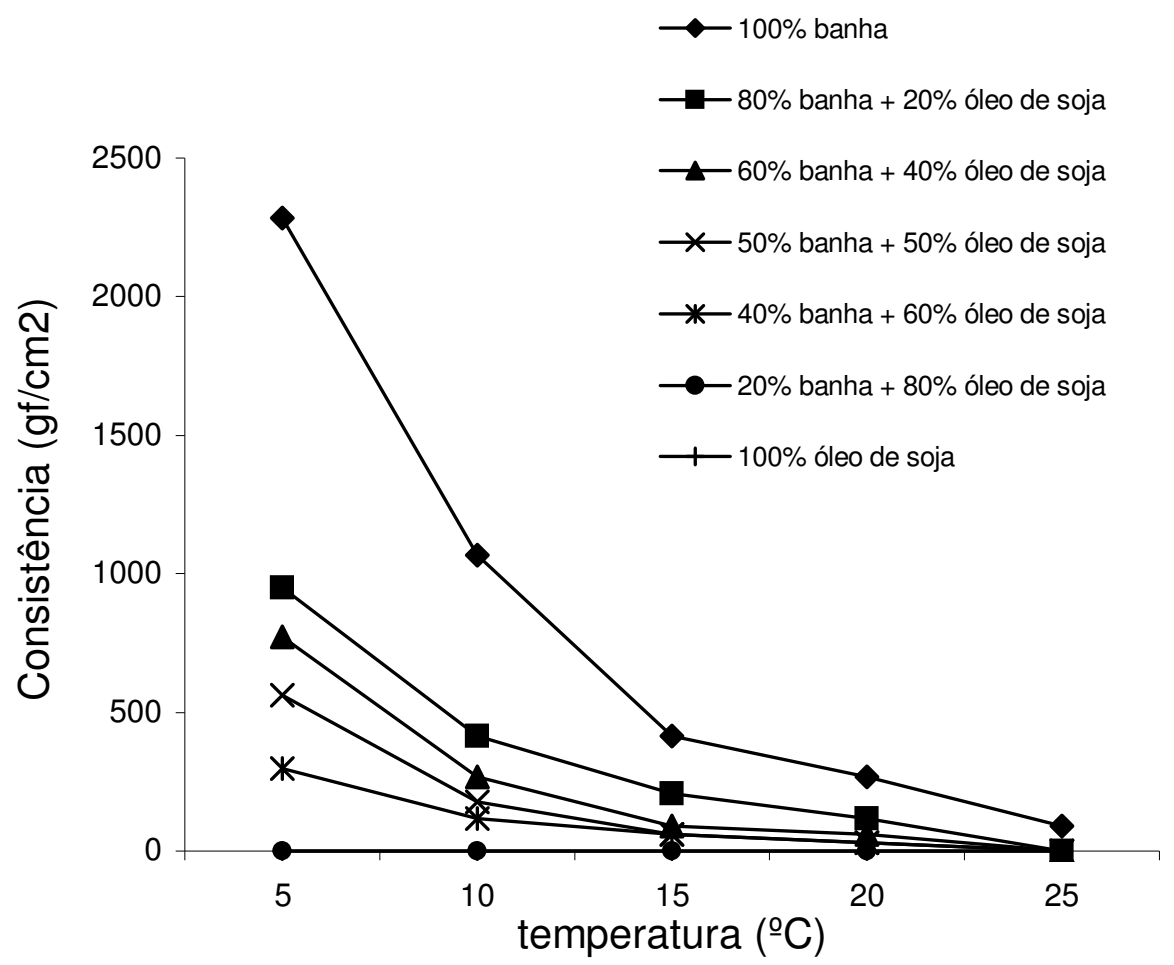

Figura 11. Consistência da banha, do óleo de soja e das misturas binárias antes da interesterificação.

A Tabela 14 apresenta os coeficientes calculados por regressão múltipla a partir dos resultados de consistência antes da interesterificação. Os coeficientes não significativos $(p>0,05)$ foram eliminados. Os resultados indicaram que as respostas analisadas foram dependentes da banha e das interações entre os dois componentes. Os coeficientes negativos para a interação demonstram também um efeito antagônico, característicos de interações monotéticas. 
Tabela 14. Coeficientes calculados por regressão múltipla a partir dos resultados experimentais de consistência antes da interesterificação.

\section{Coeficientes}

Temperatura

\begin{tabular}{llll}
\hline$\beta_{1}$ & $\beta_{2}$ & $\beta_{12}$ & $\mathrm{R}^{2}$
\end{tabular}

$\left({ }^{\circ} \mathrm{C}\right)$

\begin{tabular}{ccccc}
\hline 5 & 2126 & 0 & -2528 & 0,953 \\
10 & 990 & 0 & -1448 & 0,959 \\
15 & 399 & 0 & -573 & 0,983 \\
20 & 253 & 0 & -390 & 0,979 \\
25 & 82 & 0 & -182 & 0,951
\end{tabular}

$\beta_{1}$ - banha, $\beta_{2}$ - óleo de soja, $\beta_{12}$ - interação entre a banha e óleo de soja, $R^{2}$ coeficiente de determinação.

A consistência da banha e suas misturas binárias com óleo de soja foram significativamente alteradas pela interesterificação química (Figura 12).

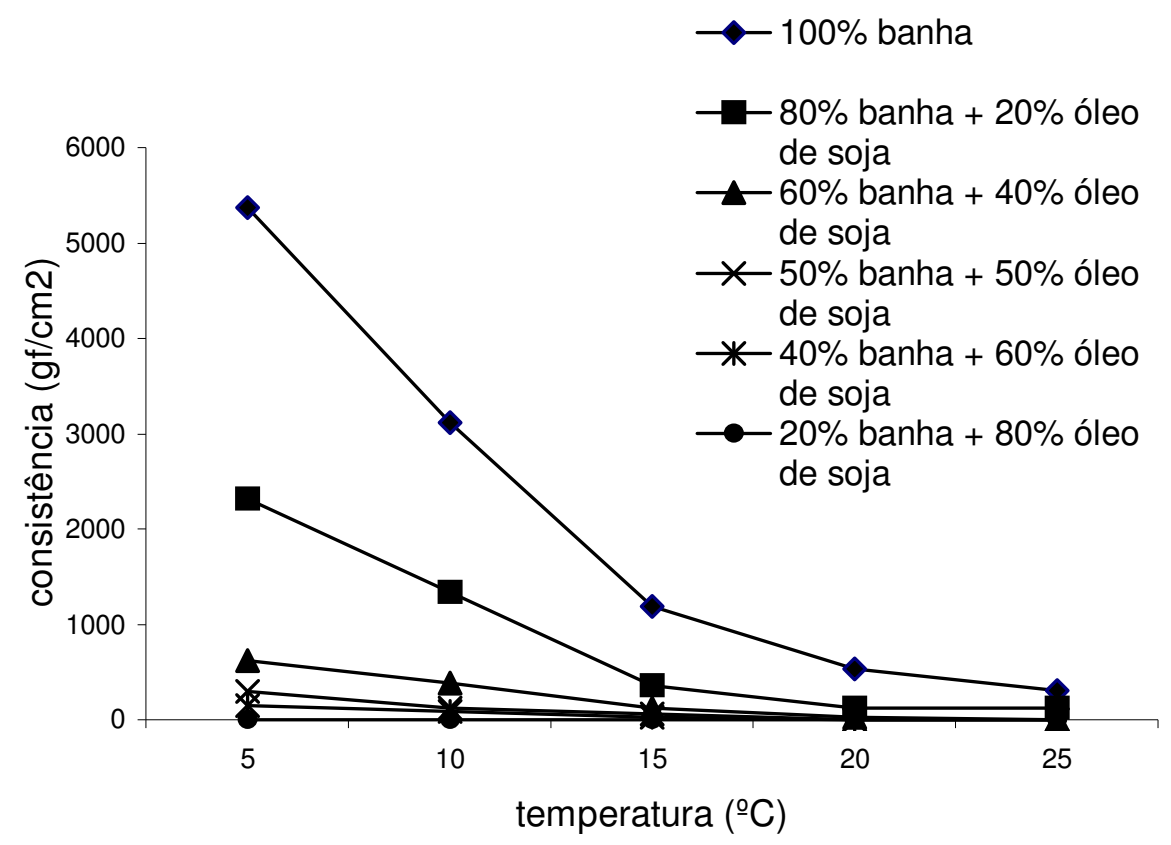

Figura 12. Consistência da banha, do óleo de soja e das misturas binárias após a interesterificação.

A interesterificação provocou aumento na consistência da banha e das misturas que continham 20 e $40 \%$ de óleo de soja em todas as temperaturas, 
provavelmente devido ao rearranjo dos ácidos graxos nas moléculas dos triacilgliceróis, aumentando a proporção de triacilgliceróis di e trissaturados (D’AGOSTINI \& GIOIELLI, 2002). Por outro lado, as misturas que continham mais que $50 \%$ de óleo de soja tiveram seu valor de consistência reduzido, devido à incorporação dos ácidos graxos poliinsaturados (ROUSSEAU et al., 1996).

A Tabela 15 mostra os coeficientes de regressão múltipla do tipo quadrático após a interesterificação. Assim como ocorreu com o conteúdo de gordura sólida, o efeito monotético foi mais acentuado nas amostras rearranjadas.

Tabela 15. Coeficientes calculados por regressão múltipla a partir dos resultados de consistência após a interesterificação.

\section{Coeficientes}

Temperatura $\left({ }^{\circ} \mathrm{C}\right)$

\begin{tabular}{ccccc}
\cline { 2 - 4 } 5 & $\beta_{1}$ & $\beta_{2}$ & $\beta_{12}$ & $\mathrm{R}^{2}$ \\
\cline { 2 - 5 } 10 & 5131 & 0 & -9565 & 0,98 \\
15 & 2978 & 0 & -5590 & 0,98 \\
20 & 1082 & 0 & -2172 & 0,91 \\
25 & 475 & 0 & -1067 & 0,91 \\
& 20 & 0 & -632 & 0,96
\end{tabular}

$\beta_{1}$ - banha, $\beta_{2}$ - óleo de soja, $\beta_{12}$ - interação entre a banha e óleo de soja, $R^{2-}$ coeficiente de determinação.

Foi efetuada uma correlação entre os valores experimentais de conteúdo de gordura sólida e consistência da banha e de suas misturas binárias com o óleo de soja, às temperaturas de 10 a $25{ }^{\circ} \mathrm{C}$, por regressão linear simples. Os coeficientes de regressão e de determinação estão apresentados nas Tabelas 16 e 17 para antes e após a interesterificação, respectivamente. A equação da reta correspondente é a seguinte:

$$
y=a+b x
$$

onde: $y=$ conteúdo de gordura sólida (\%)

$\mathrm{x}=$ consistência $\left(\mathrm{g} / \mathrm{cm}^{2}\right)$

$\mathrm{a}=$ coeficiente linear

$\mathrm{b}=$ coeficiente angular 
As misturas que continham mais de $60 \%$ de óleo de soja não apresentaram valores de consistência suficientes para estabelecer uma correlação significativa.

Tabela 16. Coeficientes de regressão linear simples e coeficiente de determinação para conteúdo de gordura sólida e consistência antes da interesterificação.

\begin{tabular}{cccc}
\hline & $b$ & $a$ & $\mathrm{R}^{2}$ \\
\hline Banha & 0,013 & 17,98 & 0,83 \\
$80 \%$ banha $+20 \%$ óleo de soja & 0,029 & 12,38 & 0,94 \\
$60 \%$ banha $+40 \%$ óleo de soja & 0,039 & 8,38 & 0,87 \\
$50 \%$ banha $+50 \%$ óleo de soja & 0,053 & 6,25 & 0,75 \\
$40 \%$ banha $+60 \%$ óleo de soja & 0,080 & 3,05 & 0,94
\end{tabular}

Tabela 17. Coeficientes de regressão linear simples e coeficiente de determinação para conteúdo de gordura sólida e consistência após a interesterificação.

\begin{tabular}{cccc}
\hline & $b$ & $a$ & $R^{2}$ \\
\hline Banha & 0,009 & 11,35 & 0,90 \\
$80 \%$ banha + $20 \%$ óleo de soja & 0,015 & 7,73 & 0,83 \\
$60 \%$ banha + $40 \%$ óleo de soja & 0,035 & 3,81 & 0,98 \\
$50 \%$ banha + 50 \% óleo de soja & 0,093 & 1,61 & 0,93 \\
$40 \%$ banha + 60 \% óleo de soja & 0,112 & 1,66 & 0,93 \\
\hline
\end{tabular}

Os resultados mostraram que houve relação linear significativa a $p<0,05$ entre as propriedades para todas as misturas, tanto antes como após a interesterificação. O coeficiente linear representa o conteúdo de gordura sólida quando a consistência é igual a zero. Os valores variam de 18,0 a 3,1\% antes da interesterificação e de 11,4 a 1,6\% após a interesterificação. Isto mostra que quando o teor de sólidos na gordura é muito baixo, o material apresenta se como um líquido viscoso, ao invés de se comportar como uma gordura plástica. Quando a proporção de gordura no estado sólido é maior que cerca de 15\%, o liquido é imobilizado pela matriz cristalina, tornando a gordura plástica (LARSSON, 1994). 


\subsection{CONCLUSÕES}

A adição de óleo de soja provocou decréscimo no conteúdo de gordura sólida e consistência da banha. A interesterificação química alterou o comportamento destas propriedades na banha e suas misturas binárias com o óleo de soja, em todas as proporções.

Os resultados da consistência e conteúdo de gordura sólida demonstraram que as interações entre as misturas foram significativas e os coeficientes negativos das interações representaram um efeito monotético entre estes componentes antes e após a interesterificaçao química.

Dentre as misturas modificadas, as que continham banha com 20 e $40 \%$ de óleo de soja foram as que mais se aproximaram da composição em ácidos graxos dos lipídios do leite humano. 


\subsection{REFERÊNCIAS BILIOGRÁFICAS}

AGENCIA NACIONAL DE VIGILÂNCIA SANITÁRIA. Legislação. VisaLegis. Resolução RDC n.482, de 23 de setembro de 1999. Aprova o Regulamento Técnico para fixação de identidade e qualidade de óleos e gorduras vegetais. Disponível em: http://elegis.anvisa.gov.br/leisref/public/showAct.php?id=135\&word=. Acesso em: 9 nov. 2004.

AGOSTONI, C. Compliance of present recommendations of fatty acids in formulas for term infants with the actual human milk fatty acid composition in different populations. Acta Paediatrics. v.92, n.7, p.785-789, 2003.

AKOH, C.C.; MOUSSATA C.O. Lipase-catalysed modification of borage oil: incorporation of capric and eicosapentanoic acids to form a structured lipid. Journal of the American Oil Chemists' Society. v.75, n.6, p.697-701, 1998.

AMERICAN OIL CHEMISTS' SOCIETY Official methods and recommended practices of the AOCS. 4.ed. Champaign, 1990.

CARNIELLI, V.P.; LUIJENDIJK, I.H.T.; VANGOUDOEVER, J.B.; SUKERS, E.J.; BOERLAGE, A.A.; DEGENHART, H.J.; SAUER, P.J.J. Feeding premature newborn infants palmitic acid in amounts and stereoisomeric position similar to human milk: effects on fat and mineral balance. American Journal of Clinical Nutrition. v.61, n.5, p.1037-1042, 1995.

CHRISTIE, W.W. Composition and structure of milk lipids. In P.F. Fox, ed., Advanced dairy chemistry - 2 Lipids, Chapman \& Hall, London, p.1-36, 1995.

CLARK, A. M.; HUNDRIESER, K.E. A lack of correction among fatty acids associated with different lipid classes in human milk. Lipids. v.29, n.2, p.157-159, 1993.

CODEX ALIMENTARIUS. Official Standards. Official Codex Standards. List. Codex Stan - 211 - 1999 - Standards for Named Animal Fats. Disponível em: http://www.codexalimentarius.net/web/standard list.do?lang=en. Acesso em: 9 nov. 2004.

D'AGOSTINI, D.; GIOIELLI, L.A. Distribuição estereoespecífica de lipídios estruturados a partir de gorduras de palma, palmiste e triacilgliceróis de cadeia média. Revista Brasileira de Ciências Farmacêuticas, v.38, n.3, p.345-354, 2002.

DAVENEL, A.; RIAUBLANC, A.; MARCHAL, P.; GANDEMER, G. Quality of pig adipose tissue: relationship between solid fat content and lipid composition. Meat Science. v.51, n.1, p.73-79, 1999.

DE FOUW, N.J.; KIVITS, G.A.A.; QUINLAN, P.T.; VAN NIELEN, W.G.L. Absortion of isomeric pamitic acid-containing triacylglycerols resembling human milk fat in the adult rat. Lipids. v.29, n.4, p.765-770, 1994. 
DEMAN, J.M. Consistency of fats: a review, Journal of the American Oil Chemists' Society. v.60, n.1, p.6-11,1983.

DEMAN, L.; SHEN, C.F.; DEMAN, J.M. Composition of physical and textural characteristics of soft (tub) margarines. Journal of the American Oil Chemists' Society. v.68, n.1, p.70-73, 1991.

DÍAZ GAMBOA, O.W.; GIOIELLI, L.A. Consistencia de lípidos estructurados a partir de aceite de pescado y grasa de palmiste. Grasas y Aceites. v.54, n.2, p.122-129, 2003a.

DÍAZ GAMBOA, O.W.; GIOIELLI, L.A. Lípidos estructurados obtenidos por interesterificación química y enzimática a partir de aceite de pescado y grasa de semilla de palma. Grasas y Aceites. v.54, n.2, p.161-168, 2003b.

FORSYNTH, J.S., Lipids and infant formulas. Nutrition Research Reviews, v.11, p.255-278, 1998.

GIOIELLI, L.A. Lipídios estruturados. In: CURI, R.; POMPÉIA, C.; MIYASAKA, C.K.; PROCOPIO, J., eds. Entendendo a gordura: os ácidos graxos. São Paulo: Manole, 2002. p.457-465.

GIOIELLI, L.A. Interesterificação de óleos e gorduras. Revista Engenharia de Alimentos. v.4, n.21, p.22-24, 1998.

GLÄSER, K.R.; WENK, C.; SCHEEDER, R.L. Evaluation of pork backfat firmmes and lard consistency using several different physicochemical methods. Journal of the Science of Food and Agriculture. v.84, n.8, p.853-862, 2004.

HAIGHTON, A.J. The measurement of the hardness of margarine and fats with cone penetrometers. Journal of the American Oil Chemists' Society. v.36, n.8, p.345348,1959 .

HARTMAN, L.; LAGO, R. C. A. Rapid preparation of fatty acid methyl esters from lipids. Laboratory Practices, v.22, p.475-494, 1973.

HOFFMAN, G. The chemistry and technology of edible oils and fats products. London: Academic Press, p.201-338, 1989.

HUI, Y.H., ed. Bailey's industrial oil and fat products. 5ª ed., New York: Wiley, p. 497-601, 603-654, 1996.

INNIS, S.M.; DYER, R.; NELSON, C.M. Evidence that palmitic acid is absorbed as $s n-2$ monoacylglycerol from human milk by breast-fed infants. Lipids. v.29, n.8, p.541-545, 1994.

JENSEN, C.; BUIST, N.R.M.; WILSON, T. Absortion of individual fatty acids form long chain or medium chain triglycerides in very small infants. American Journal of Clinical Nutrition. v.43, n.1, p.77-131, 1986. 
JENSEN, R.G. Human milk lipids as a model for infant formulas. Lipid Technology., v.12, n.3, p.34-38, 1998.

KARABULUT, I.; TURAN, S.; ERGIN, G. Effects of chemical interesterification in solid fat content and slip melting point of fat/oil blends. European Food Research Technology. v.218, n.3, p.224-229, 2004.

KNOESTER, M.P.; B. VAN DEN TEMPEL. The solid-liquid equilibrium of binary mixtures of triglycerides with palmitic and stearic chains. Chemistry and Physics of Lipids. v.9, n.4, p.309-319, 1972.

LARSSON, K.A. Lipids: molecular organization, physical functions and technical applications. Dundee: The Oil Press, 1994. 237p.

LEE, K.T.; AKOH, C.C. Characterization of enzymatically syntetized structured lipids containing eicosapentaenoic, docosahexanoic and caprylic acids, Journal of the American Oil Chemists' Society. v.75, n.4, p.495-499, 1998.

LIEN, E.L. The role of fatty acid composition and positional distribuition in fat absoption in infants. Journal of Pedriatrics. v.125, n.5, p.562-568, 1994.

LIEN, E.L; BOYLE, F.G.; YUHAS, R.; TOMARELLI, R.M.; QUINLAN, P. The effect of triglyceride positional distribuition on fatty acid absortion in rats. Journal of Pediatric Gastroenterology and Nutrition. v.25, n.2, p.167-174, 1997.

LUCAS, A.; QUINLAN, P.; ABRAMS, S.; RYAN, S.; MEAH, S.; LUCAS, P.J. Randomized controlled trial of a synthetic triglyceride milk formula for preterm infant. Archives of Disease in Childhood, v.77, n.3, p.F178-F184, 1997.

MARANGONI, A.G.; ROUSSEAU, D. The influence of chemical interesterification on physicochemical properties of complex fat systems 1 . Melting and crystallization. Journal of the American Oil Chemists' Society. v.75, n.10, p.1265-1271, 1998a.

MARANGONI, A.G.; ROUSSEAU, D. The influence of chemical interesterification on physicochemical properties of complex fat systems. 3. Rheology and fractality of the crystal network. Journal of the American Oil Chemists' Society. v.75, n.11, p.1633-1636, $1998 \mathrm{~b}$.

MARTIN, J.C.; BOUGNOUX, P.; ANTONIE, J.M.; LANSON, M.; COUET, C. Triacylglycerols structure of human colostrum and mature milk. Lipids, v.28, n.7, p. 637-643, 1993.

NEFF, W.E.; BYRDWELL, W.C.; STEIDELEY, K.R.; LIST,G.R.; SNOWDER, G. Triacylglycerol structure of animal tallows, potential food formulation fats, by high performance liquid chromatography coupled with mass spectrometry. Journal of Liquid Chromatography \& Related Technologies. v.25, n.6, p.985-998, 2002

NOOR LIDA, H.M.D.; SUNDRAM, K.; SIEW, W.L., AMINAH, A.; MAMOT, S. TAG composition and solid fat content of palm oil, sunflower oil, and palm kernel olein 
blends before and after chemical interesterification. Journal of the American Oil Chemists' Society. v.79, n.10, p.1138-1143, 2002

O'BRIEN, R.D. Fats and oils - Formulating and processing for applications. Lancaster, Pa. Technomic Pub. Co.,, 1998. p.7-10, 33-36, 98-108.

OSBORN, H.T.; AKOH, C.C. Structured lipids - novel fats with medical, nutraceutical, and food applications. Comprehensive Reviews in Food Science and Food Safety, v.3, n.1, p.93-103, 2002.

PETRAUSKAITE, V.; DE GREYT, W.; KEKKENS, M.; HUIGHEBAERT, A. Physical and chemical properties of trans free fats produced by chemical interesterification of vegetable oil blends. Journal of the American Oil Chemists' Society. v.5, p.489493, 1999.

POUZET, A. Presentation of some results of the Concerted Action on the management of oilseed crops in the European Union. OCL - Oleagineux Corps Gras Lipides, v.6, n.1, p.6-21, 1996.

RODRIGUES, J.N.; GIOIELLI, L.A. Chemical interesterification of milkfat-corn oil blends. Food Research International. v.36, n.2, p.149-159, 2003.

ROUSSEAU, D.; MARANGONI A.G.; JEFFREY, K.R. The influence of chemical interesterification on the physicochemical proprerties of complex fat systems 2 . morphology and polymorphism. Journal of the American Oil Chemists' Society. v.75, n.12, p.1833-1839, 1998.

ROUSSEAU, D.; FORESTIERE, K., HILL, A.R.; MARANGONI, A.G. Restructuring butterfat through blending and chemical interesterification. 1. Melting behavior and triacylglycerol modifications. Journal of the American Oil Chemists' Society. v.73, n.8, p.963-972, 1996.

SUMMERS, L.M.K.; FIELDING, B.A.; ILIC, V.; QUINLAN, P.T; FRAYN K.N. The effect of triacylglycerol-fatty acid position on postprandial metabolism in subcutaneous adipose tissue. British Journal of Nutrition. v.79, p.41-147, 1998.

WILLIS, W.M.; MARANGONI, A.G. Assessment of lipase and chemically catalysed lipid modification strategies for the production of structured lipids. Journal of the American Oil Chemists' Society. v.76, n.4, p.443-450, 1999.

YANG T.K.; XU, X.B; HE, C.; LI, L.T. Lipase-catalyzed modification of lard to produce human milk fat substitutes. Food Chemistry. v.80, n.4, p.473-481, 2003.

ZEITON, M.A.M. ; NEFF, W.E.; LIST, G.R.; MOUNTS, T.L. Physical properties of interesterified fat blends Journal of the American Oil Chemists' Society. v.70, n.4, p.467-471, 1993. 


\section{Comportamento de cristalização de lipídios}

estruturados por interesterificação química de banha e óleo de soja

SILVA, R.C.; ESCOBEDO, J.P.; GIOIELLI, L.A. Comportamento de cristalização de lipídios estruturados por interesterificação química de banha e óleo de soja. Química Nova. v.31, n.2, p.330-335, 2008. 


\section{RESUMO}

O comportamento de cristalização de lipídios tem implicações no processamento industrial de produtos cujas características físicas dependem em grande parte de cristais de gordura, como chocolates, margarinas e shortenings. As velocidades de formação e de crescimento dos cristais e as transformações polimórficas são importantes para se determinar o processo e as condições de armazenamento de óleos e gorduras. $O$ trabalho teve o objetivo de avaliar o comportamento de cristalização de misturas de banha e óleo de soja, em diferentes proporções. Observou-se que a tendência de cristalização da banha se manteve nas misturas com o óleo de soja, porém a cristalização foi dificultada pelo efeito da diluição. Houve tendência a aumentar o diâmetro e diminuir o número dos cristais à medida que aumentava a participação do óleo de soja mistura. O diâmetro médio dos cristais de todas as amostras aumentou com o aumento da temperatura, atingindo valores da ordem de $200 \mu \mathrm{m}$. O número de cristais diminuiu com o aumento da temperatura. À temperatura de $15^{\circ} \mathrm{C}$ a dimensão fractal apresentou tendência a diminuir com o aumento da participação do óleo de soja na mistura, em função do menor grau de preenchimento da estrutura cristalina, indicando menor ordem de empacotamento dos elementos microestruturais. 


\subsection{INTRODUÇÃO}

Lipídios estruturados podem ser definidos como triacilgliceróis reestruturados ou modificados para alterar a composição em ácidos graxos e/ou sua distribuição nas moléculas de glicerol, por métodos químicos, enzimáticos ou de engenharia genética (LEE \& AKOH, 1998; OSBORN \& AKOH, 2002).

Os lipídios estruturados são normalmente obtidos por interesterificação. Este processo promove alteração na distribuição dos ácidos graxos nos triacilgliceróis, afetando a natureza física e o comportamento dos lipídios. A interesterificação catalisada por via química ou por lipases é utilizada na indústria de óleos e gorduras para a fabricação de margarinas e "shortenings" (GIOIELLI, 2002; HUY, 1996).

A interesterificação química é uma reação ao acaso que produz completa randomização dos ácidos graxos nos triacilgliceróis (WILLIS \& MARANGONI, 1999). Sob a perspectiva de custo e aplicação em larga escala, a interesterificação química parece ser o método mais atrativo. Contudo, sob a perspectiva de produzir lipídios com composições muito específicas para aplicações funcionais e medicinais, os métodos de interesterificação enzimática são mais interessantes (WILLIS et al.,1998).

As propriedades macroscópicas de lipídios, como a espalhabilidade de margarinas e manteigas, são influenciadas particularmente pela microestrutura das gorduras. Por isso, é importante considerar os efeitos da microestrutura para posterior análise das propriedades macroscópicas (NARINE \& MARANGONI, $\left.1999^{\mathrm{a}}\right)$.

O comportamento de cristalização de lipídios tem implicações importantes, principalmente no processamento industrial de produtos cujas características físicas dependem em grande parte de cristais de gordura, como chocolates, margarinas e shortenings, assim como na separação de frações específicas a partir de gorduras naturais, através do fracionamento (O'BRIEN, 1998). As velocidades de formação e de crescimento dos cristais e as transformações polimórficas são importantes para se determinar o processo e as condições de armazenamento de óleos e gorduras (SIMÕES \& GIOIELLI, 1999).

As gorduras são polimórficas, podendo existir em três principais formas cristalinas, $\alpha, \beta^{\prime}$ ou $\beta$-prima e $\beta$, de acordo com a estrutura da sub-célula (secção 
transversal do modo de empacotamento das cadeias carbônicas). Dependendo da composição em ácidos graxos dos triacilgliceróis outras formas polimórficas metaestáveis, chamadas $\gamma$ e $\delta$, e sub-formas de $\beta$ e $\beta$-prima foram observadas. As transformações de $\alpha$ para $\beta$-prima e desta para $\beta$ ocorrem nesta ordem e são irreversíveis, exceto por fusão e recristalização. Em geral, pode-se afirmar que as gorduras de composição homogênea tendem a apresentar a forma $\beta$, enquanto as de composição heterogênea tendem à forma $\beta$-prima (TIMMS, 1995). Dentre as três formas polimórficas, a $\beta$ é a mais estável, $\beta$-prima é metaestável e a $\alpha$ a menos estável (MARANGONI, 2002). A forma $\beta$ é mais densamente empacotada, o que implica em maiores consistência e ponto de fusão (WRIGHT et al., 2001).

Durante a cristalização, o crescimento da rede sólida começa com sítios iniciais de nucleação, que crescem formando cristais maiores quando moléculas adicionais de triacilgliceróis cristalizam-se. Estes cristais maiores formam elementos microestruturais de aproximadamente $10 \mu \mathrm{m}$, que então se agregam em grupos maiores, chamados de microestruturas, da ordem de $100 \mu \mathrm{m}$ ou mais. Estes grupos se empacotam de modo regular e homogêneo, formando os blocos estruturais da rede cristalina da gordura. Entre os elementos microestruturais e as microestruturas fica a fase líquida da rede (óleo) (HERRERA et al.,1998). Quando a rede cristalina é submetida a uma tensão, as ligações entre as microestruturas têm maior probabilidade de serem rompidas que os elementos microestruturais dentro delas (LARSSON, 1994).

O processo de cristalização é dividido nas fases de nucleação e crescimento dos cristais. A nucleação envolve a formação de agregados de moléculas que excederam um tamanho crítico e são, portanto, estáveis (SIMÕES \& GIOIELLI, 1999). Uma vez que o núcleo cristalino se formou, este começa a crescer pela incorporação de outras moléculas, no cristal em crescimento. A velocidade de crescimento de um cristal é diretamente proporcional ao superesfriamento e inversamente proporcional à viscosidade da solução. Quanto mais alta é a viscosidade, mais difícil se torna a troca de matéria entre a fase líquida e a superfície do cristal e mais lento será seu crescimento (HUI, 1996, WRIGHT et al., 2001, ROUSSEAU et al., 1996). Devido a interações atrativas entre os cristais, os grandes cristais que podem ser observados durante a cristalização são normalmente formados por pequenos cristais unidos por ligações fracas. A morfologia dos cristais 
é determinada por condições internas e externas. A cinética de cristalização de uma gordura depende da velocidade de formação do núcleo, bem como da velocidade de crescimento dos cristais. O tamanho e a forma dos cristais dependem da relação entre estes dois fatores. Normalmente, o resfriamento lento resulta em cristais grandes, enquanto que o resfriamento rápido produz cristais menores (HUI, 1996).

Muitos fatores influenciam a cristalização dos lipídios, especialmente a maneira como estes são resfriados, a partir de seu estado líquido, pois quando um óleo líquido é resfriado, uma fase sólida se separa, cuja composição e quantidade dependem principalmente da velocidade de resfriamento e das temperaturas inicial e final (ROUSSEAU et al., 1996, NARINE \& MARANGONI, 1999º).

Os triacilgliceróis são moléculas orgânicas bem conhecidas e, portanto, os ângulos e comprimentos das ligações entre os vários átomos dentro de cada molécula são estabelecidos baseando-se na química orgânica estrutural padrão. Mesmo assim não é fácil prever a estrutura cristalina particular formada por um conjunto de moléculas de triacilgliceróis de orientação estereoespecífica conhecida. A complexidade e a flexibilidade destas moléculas também permitem diferentes empacotamentos do mesmo conjunto de moléculas, levando a existência de diferentes formas polimórficas (NARINE \& MARANGONI, 1999').

A dimensão fractal ocorre quando um objeto é classificado como sendo intermediário entre uma linha e um plano ou entre um plano e um cubo. Essa denominação decorre do fato que, ao invés desse objeto apresentar uma dimensão Euclidiana (integral), ele possui uma dimensão fracionária. Objetos fractais são muito similares entre si, por isso a geometria fractal promove boa medida desses objetos (MARANGONI \& HARTEL, 1998). MARANGONI \& HARTEL (1998) estudaram a estrutura da rede cristalina de gorduras, combinando técnicas microscópicas e reológicas com a análise de fractais. Estes autores citaram que a maioria da pesquisa científica tem sido dirigida a estabelecer relações entre composição lipídica ou polimorfismo e propriedades macroscópicas de gorduras, sem considerar muito a microestrutura da rede cristalina. A não inclusão da microestrutura como uma variável importante pode levar a falhas na previsão de propriedades macroscópicas. WRIGHT et al. (2001) indicaram que a dimensão fractal, determinada por reologia, da rede cristalina da gordura do leite diminuiu de 2,5 para 2,0 quando a velocidade de resfriamento da gordura foi aumentada. Isto demonstrou que maiores velocidades 
de resfriamento levam a decréscimo da ordem na distribuição espacial da rede microestrutural, o que resulta em menor valor para a dimensão fractal. Sistemas com maiores valores para a dimensão fractal demonstram maior ordem de empacotamento dos elementos microestruturais do que aqueles com menores valores.

MARANGONI \& ROUSSEAU (1996) afirmaram que existe a possibilidade de que não seja o conteúdo de gordura sólida e/ou a forma polimórfica do cristal que determinam as propriedades mecânicas das misturas de gordura do leite com óleo de canola, mas sim a estrutura macroscópica da rede de cristais na matriz líquida oleosa. Através do estudo das dimensões fractais e da aplicação desta teoria aos estudos de reologia das misturas de gordura do leite com óleo de canola, estes pesquisadores observaram que a dimensão fractal (D) foi o único "indicador" que variou seguindo as mudanças associadas à reologia do produto decorrentes da interesterificação. Os indicadores físicos tradicionais, como polimorfismo e conteúdo de gordura sólida falharam em demonstrar as mudanças esperadas. Assim, ficou clara a importância da dimensão fractal, um indicador fundamental da rede cristalina que podia ser usado para explicar mudanças na reologia das gorduras não atribuídas a outras propriedades mensuráveis da rede (NARINE \& MARANGONI, $\left.1999^{\mathrm{a}, \mathrm{b}, \mathrm{c}, \mathrm{d}}\right)$.

Os parâmetros de Avrami fornecem informações sobre a natureza do processo de cristalização. A constante $\mathrm{k}$ representa a velocidade de cristalização. Depende principalmente da temperatura de cristalização e esta dependência é geralmente expressa pela equação de Arrhenius. A constante $k$ leva em consideração tanto a nucleação quanto a taxa de crescimento dos cristais. O expoente de Avrami n, às vezes chamado de índice de cristalização, indica o mecanismo de crescimento dos cristais. Este parâmetro é uma função combinada da dependência do tempo por parte da nucleação e do número de dimensões em que o crescimento ocorre. A nucleação pode ser instantânea, com os núcleos surgindo todos de uma só vez no início do processo, ou esporádica, com o número de núcleos aumentando linearmente com o tempo. O crescimento ocorre tomando formas de agulhas, discos ou esferulitos, em uma, duas ou três dimensões, respectivamente (WRIGHT et al., 2000). 
Os lipídios estruturados a partir de banha e óleo de soja têm características que possibilitam seu uso como sucedâneos da gordura do leite humano (SILVA \& GIOIELLI, 2006).

Este trabalho teve por objetivo analisar a estrutura cristalina da banha em misturas binárias com óleo de soja, modificadas pelo uso da interesterificação química. 


\subsection{MATERIAL E MÉTODOS}

A banha e o óleo de soja foram obtidos no comércio local.

As misturas foram preparadas nas seguintes proporções banha: soja (p/p): 100:0, 80:20 e 60:40, após fusão completa à temperatura de $70 \stackrel{\circ}{\circ}$ e novamente solidificadas, sendo armazenadas sob resfriamento.

\subsubsection{Interesterificação química}

Foram interesterificados $250 \mathrm{~g}$ de amostra, previamente submetida à secagem em balão de vidro, sob pressão reduzida, acoplado a um rotaevaporador em banho de água a aproximadamente $95^{\circ} \mathrm{C}$. A essa porção foram misturados $0,5 \%$ $(\mathrm{m} / \mathrm{m})$ de catalisador metóxido de sódio (Merck). A reação de interesterificação foi realizada sob agitação constante, sob pressão reduzida $\left(20-30 \mathrm{~mm} \mathrm{Hg}\right.$ ), a $70^{\circ} \mathrm{C}$ em balão de três bocas imerso em banho de água a $70 \stackrel{\circ}{ } \mathrm{C}$, por 1 hora. Para interromper a reação foi adicionada água destilada. Para minimizar o escurecimento decorrente da reação e para reter a umidade, respectivamente, foram adicionados sílica em pó e sulfato de sódio anidro. Os produtos foram filtrados a quente utilizando-se papel de filtro (DÍAZ GAMBOA \& GIOIELLI, 2003룰, RODRIGUES \& GIOIELLI, 2003).

\subsubsection{Microscopia sob luz polarizada}

As amostras foram fundidas à temperatura de $70 \stackrel{\circ}{\mathrm{C}}$ para preparação das lâminas para microscopia. As lâminas, lamínulas e tubos capilares foram préaquecidos em estufa a $70 \stackrel{\circ}{ } \mathrm{C}$. Usando um tubo capilar, uma gota de gordura foi depositada sobre a lâmina e coberta com uma lamínula. As amostras preparadas foram mantidas à temperatura de $70 \stackrel{\circ}{ } \mathrm{C}$ durante 30 minutos. Foram preparadas duas lâminas de cada amostra. As lâminas foram condicionadas em estufa a 15, 20, 25 e $30 \stackrel{\circ}{ } \mathrm{C}$ por 5 horas. As amostras foram observadas com aumento de 40 vezes. $\mathrm{O}$ microscópio de luz polarizada (Olympus) foi ligado a uma câmera de vídeo digital (Media Cybernetics). A imagem foi digitalizada pelo programa de computador Image Pro-Plus versão 4.5.1.2 (Media Cybernetics). A partir das imagens vistas através do microscópio, para cada lâmina foram escolhidos quatro campos representativos. 
Com o software Image Pro-Plus 4.5.1.2 foram determinados os diâmetros e número dos cristais e com o software Benoit 1.3 (TruSoft International Inc.) foi determinada a dimensão fractal das amostras, pelo método da contagem de caixas (SIMÕES \& GIOIELLI, 1999, 2000; SOTERO-SOLIS \& GIOIELLI, 2001, MARANGONI, 2005).

\subsubsection{Cinética de cristalização}

A cinética de cristalização foi realizada pela determinação do conteúdo de gordura sólida por ressonância magnética nuclear (RMN), utilizando aparelho Maran Ultra Bench Top NMR, de $20 \mathrm{MHz}$. As amostras foram analisadas em duplicata. O seguinte tratamento térmico foi usado: as misturas já acondicionadas nos tubos de RMN foram fundidas e mantidas a $60 \stackrel{\circ}{\circ}$ por 30 min e posteriormente colocadas em banho de água na temperatura de cristalização $\left(10^{\circ} \mathrm{C}\right)$. O conteúdo de gordura sólida foi determinado em função do tempo, até 120 minutos de cristalização. A equação de Avrami original (WRIGHT et al., 2000) foi linearizada segundo a dedução a seguir e aplicada aos resultados obtidos.

$$
\begin{gathered}
1-\frac{C G S(t)}{C G S(\infty)}=e^{-k t^{n}} \\
\ln \left[1-\frac{C G S(t)}{C G S(\infty)}\right]=-k t^{n} \\
-\ln \left[1-\frac{C G S(t)}{C G S(\infty)}\right]=k t^{n} \\
\ln \left\{-\ln \left[1-\frac{C G S(t)}{C G S(\infty)}\right]\right\}=\ln k+n \ln t
\end{gathered}
$$

Onde:

CGS $(t)=$ conteúdo de gordura sólida no tempo $t$

CGS $(\infty)=$ conteúdo de gordura sólida máximo, obtido quando a cristalização está finalizada

$\mathrm{k}=$ constante de Avrami $\left(\mathrm{min}^{-1}\right)$

$\mathrm{t}=$ tempo $(\mathrm{min})$

$\mathrm{n}=$ expoente de Avrami 
A partir da equação de Avrami linearizada foram calculados a constante e o expoente de Avrami (RODRIGUES \& GIOIELLI, 2003). 


\subsection{RESULTADOS E DISCUSSÃO}

A avaliação do conteúdo de gordura sólida em função do tempo de cristalização da banha e de suas misturas com 20 e $40 \%$ de óleo de soja, antes e após a interesterificação química, permitiram a construção das curvas de cinética de cristalização a $10^{\circ} \mathrm{C}$, representadas pelas Figuras 13,14 e 15 .

banha

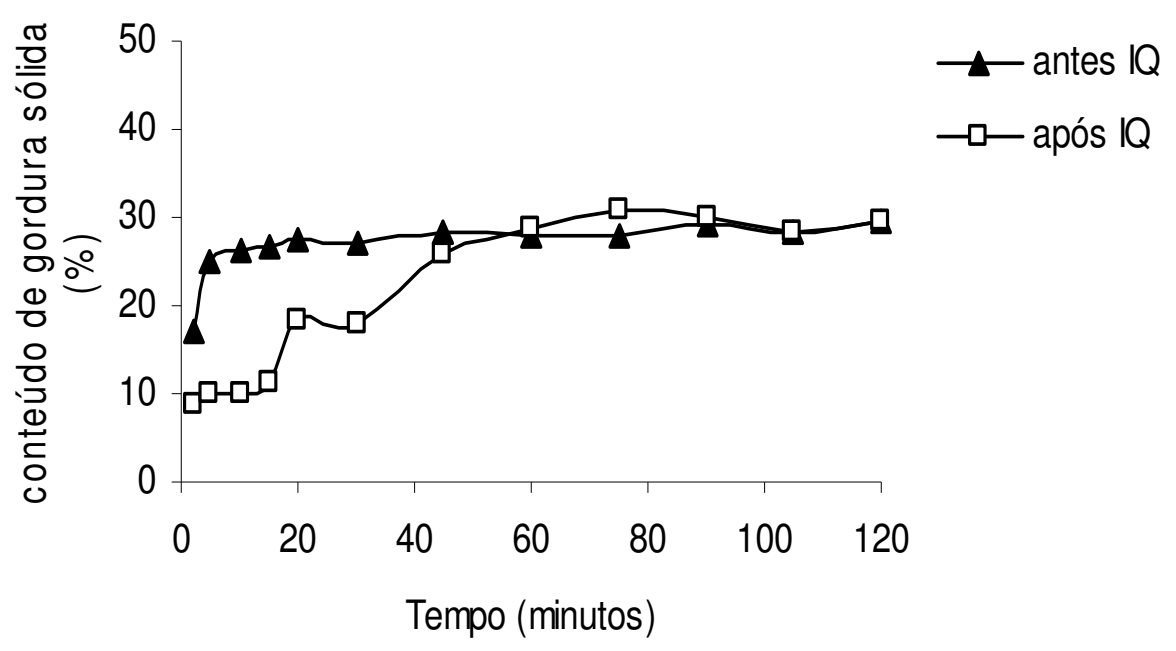

Figura 13. Cinética de cristalização a $10^{\circ} \mathrm{C}$ da banha antes e após a interesterificação. 
$80 \%$ banha $+20 \%$ óleo de soja

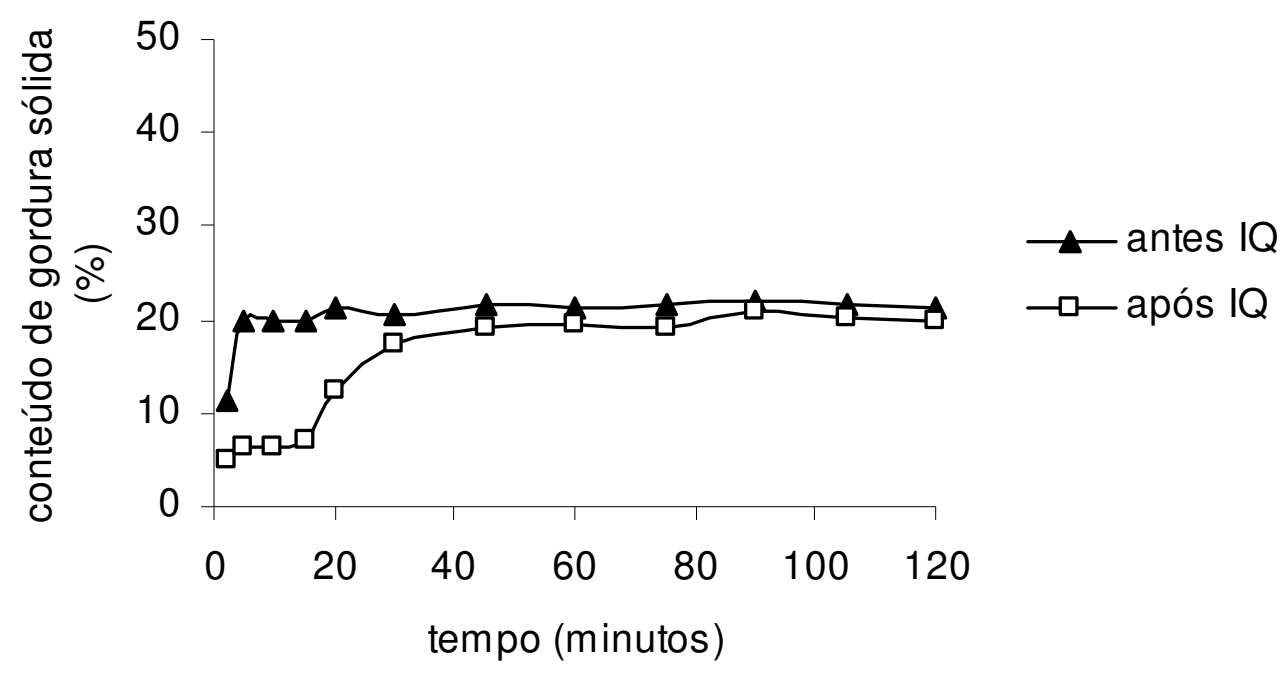

Figura 14. Cinética de cristalização a $10^{\circ} \mathrm{C}$ da mistura de banha com $20 \%$ de óleo de soja antes e após a interesterificação.

$60 \%$ banha $+40 \%$ óleo de soja

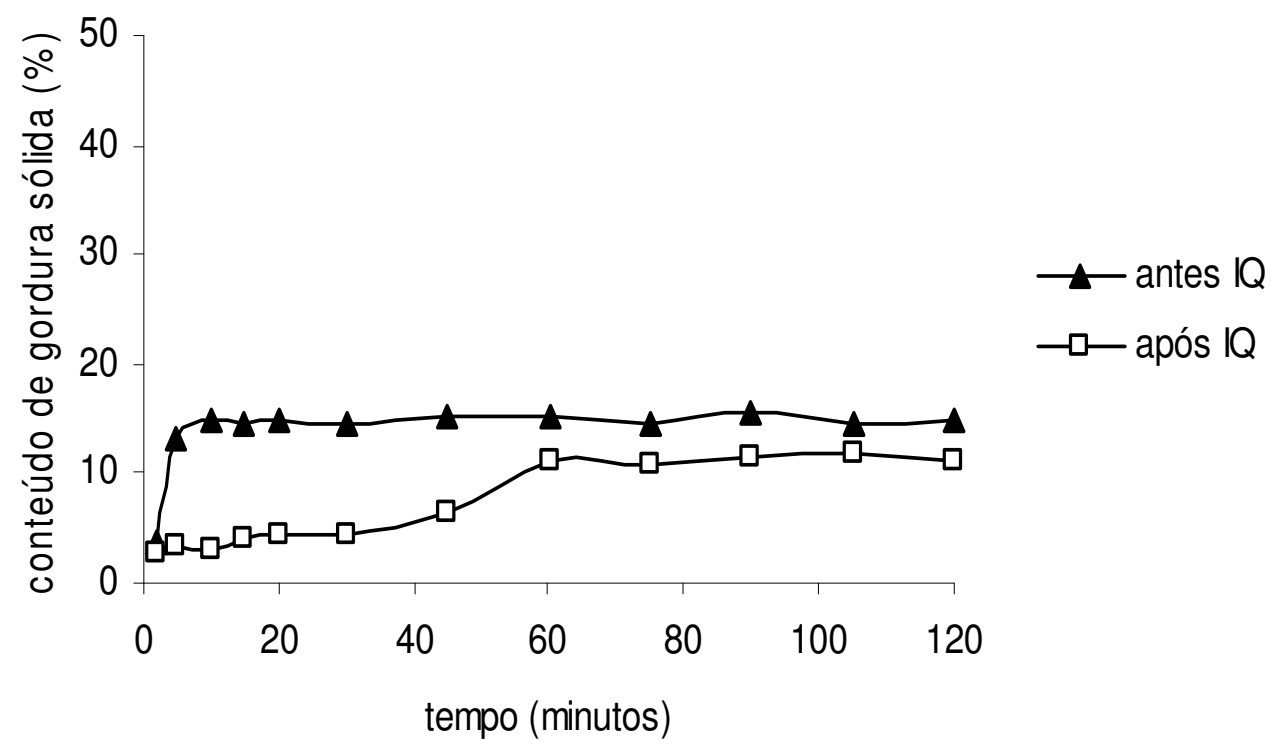

Figura 15. Cinética de cristalização a $10^{\circ} \mathrm{C}$ da mistura de banha com $40 \%$ de óleo de soja antes e após a interesterificação. 
A interesterificação mudou o formato da curva em todas as amostras. As curvas antes da interesterificação apresentavam formato hiperbólico, não apresentando período de indução inicial. Contudo, após a reação as amostras apresentaram formato sigmoidal característico do modelo de Avrami (RODRIGUES et al., 2002), com período de indução em que a cristalização ocorre lentamente. Isto pode estar relacionado à mudança na forma polimórfica da banha, que após a interesterificação tende a cristalizar na forma $\beta$ ao invés de forma $\beta$-prima (O'BRIEN, 1998).

A Tabela 18 apresenta os parâmetros de Avrami, que indicam a velocidade (k) e a forma de cristalização (n), antes e após a interesterificação.

A constante de Avrami k diminuiu com o aumento da proporção de óleo de soja na mistura, indicando que a velocidade de cristalização foi menor em função do efeito de diluição da banha com o óleo líquido. Observa-se ainda que a interesterificação promoveu queda na velocidade de cristalização das amostras.

$\mathrm{O}$ expoente de Avrami n, que indica o mecanismo de crescimentos dos cristais, aumentou com a adição de óleo de soja. Com exceção da mistura que continha $40 \%$ de óleo de soja, os valores de n situaram-se entre 0 e 1 , indicando crescimento em forma de agulha a partir de núcleos instantâneos. Na mistura que continha $40 \%$ de óleo de soja o valor do expoente foi superior a 1 , indicando a formação de cristais tipo agulha a partir de núcleos esporádicos ou cristais em forma de disco a partir de núcleos instantâneos (WRIGHT et al., 2000). Estas formas de cristalização são devidas à baixa temperatura empregada $\left(10^{\circ} \mathrm{C}\right)$. Portanto, a esta temperatura não foram detectadas diferenças significativas na forma de cristalização em decorrência da mistura de banha com óleo de soja ou da interesterificação, embora a velocidade de cristalização tenha diminuído após o rearranjo ao acaso. 
Tabela 18. Constante de Avrami (k), expoente de Avrami (n) e coeficiente de determinação $\left(R^{2}\right)$ das misturas de banha e óleo de soja antes e após a interesterificação.

\begin{tabular}{|c|c|c|c|}
\hline & $k\left(\min ^{-1}\right)$ & $\mathrm{n}$ & $\mathrm{R}^{2}$ \\
\hline & \multicolumn{3}{|c|}{ Antes da interesterificação } \\
\hline \multicolumn{4}{|l|}{ Banha:Soja } \\
\hline $100: 0$ & 0,84 & 0,44 & 0,85 \\
\hline $80: 20$ & 0,63 & 0,63 & 0,76 \\
\hline $60: 40$ & 0,14 & 1,44 & 0,46 \\
\hline & \multicolumn{3}{|c|}{ Após a interesterificação } \\
\hline \multicolumn{4}{|l|}{ Banha:Soja } \\
\hline $100: 0$ & 0,15 & 0,63 & 0,87 \\
\hline $80: 20$ & 0,11 & 0,64 & 0,81 \\
\hline $60: 40$ & 0,10 & 0,74 & 0,76 \\
\hline
\end{tabular}

As técnicas de análise microscópica são frequentemente as mais apropriadas para avaliar a estrutura de alimentos, visto que fornecem resultados tanto na forma de imagens como em dados numéricos. O sucesso nas medidas exigem vários estágios, incluindo obter uma imagem representativa do material, analisar a imagem adequadamente e interpretar os dados resultantes (STANLEY et al.,1998).

Quando a temperatura de cristalização está distante do ponto de fusão da amostra, ocorre formação de cristais menores e em maior número. Próximo ao ponto de fusão, a amostra apresenta pequeno conteúdo de gordura sólida e os cristais formados são pequenos e não possuem forma distinta, ou não se formam. Deste modo, uma temperatura intermediária de cristalização auxilia na formação de cristais maiores, em menor número e com formas distintas.

A Figura 16 apresenta a estrutura cristalina da banha antes e após a interesterificação química, por cristalização lenta na faixa de temperatura de 15 a 30 $\stackrel{\circ}{ } \mathrm{C}$. 
O resultado da cristalização das amostras pode ser analisado sob os pontos de vista do efeito da temperatura e da influência da presença do óleo de soja na formação da rede cristalina da banha, tanto antes quanto após a interesterificação.

Em relação à temperatura, como a velocidade de nucleação aumenta de forma exponencial com o aumento da supersaturação, enquanto a velocidade de crescimento é linearmente proporcional à supersaturação, o número de cristais aumenta e o tamanho dos cristais diminui quando a cristalização ocorre a baixas temperaturas (SIMOES \& GIOIELLI, 1999a; GIOIELLI, et al., 2003). Isto pode ser observado na Figura 16, onde o diâmetro médio dos cristais de todas as amostras aumentou com o aumento da temperatura, atingindo valores da ordem de $200 \mu \mathrm{m}$. À temperatura de $15{ }^{\circ} \mathrm{C}$ os cristais observados foram pequenos, da ordem de 6 a 20 $\mu \mathrm{m}$, na forma de agulhas ou discos, característicos de valores do expoente $\mathrm{n}$ de Avrami entre 1 e 3 (WRIGHT et al., 2000). Os esferulitos, que apresentam valores de $\mathrm{n}$ entre 3 e 4, somente foram observados nas temperaturas de 20 a $30{ }^{\circ} \mathrm{C}$. Da mesma forma, o número de cristais sempre diminuiu com o aumento da temperatura. O resfriamento rápido a baixa temperatura, seguido de agitação intensa leva à formação de cristais pequenos, como os encontrados na margarina. Por outro lado, o resfriamento lento sob agitação suave leva à formação de cristais grandes facilmente visíveis a olho nu. Neste caso, os cristais podem formar aglomerados de esferulitos com tamanhos de centenas de micrômetros (SIMOES \& GIOIELLI, 1999a; GIOIELLI, et al., 2003), fato importante para facilitar a filtração no processo de modificação de lipídios por fracionamento.

A banha tende a cristalizar na forma $\beta$, embora tenha uma composição em ácidos graxos heterogênea, que provocaria a cristalização na forma $\beta$-prima. Contudo, pelo fato de apresentar alta proporção de ácido palmítico na posição sn-2, a composição em triacilgliceróis pode ser considerada homogênea, o que induz à cristalização na forma $\beta$ (SATO, 2001).

A tendência de cristalização da banha pode ser modificada pela interesterificação química (ROSSEAU et al., 1998), passando a cristlizar na forma $\beta$ prima (SATO, 2001). A interesterificação química alterou o comportamento de cristalização da banha (Figura 16), causando decréscimo acentuado no número de esferulitos nas temperaturas de 15 e $20^{\circ} \mathrm{C}$, embora não tenha sido possível observar diferenças morfológicas entre as formas $\beta$ e $\beta$-prima. 


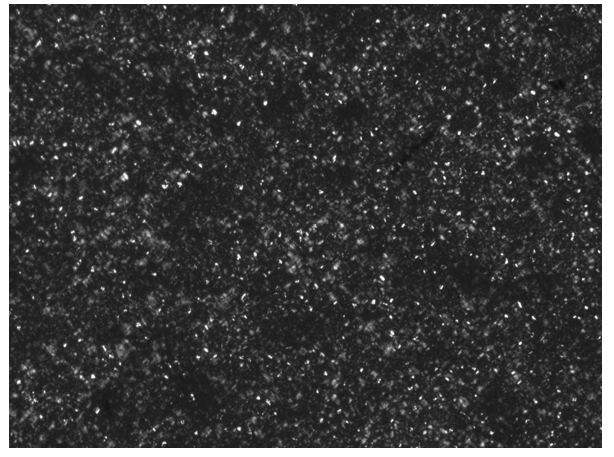

$15^{\circ} \mathrm{C}$ antes

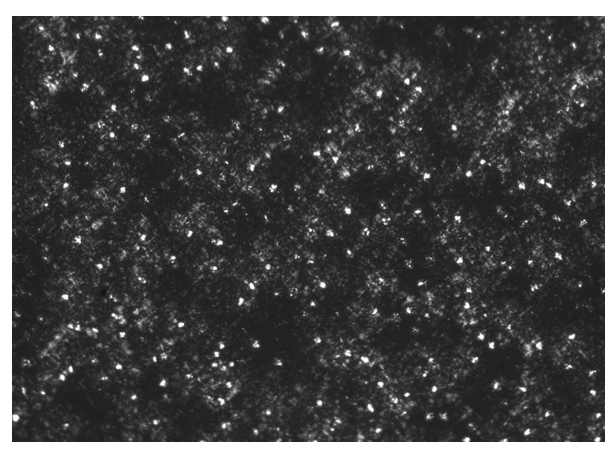

$20 \stackrel{\circ}{C}$ antes

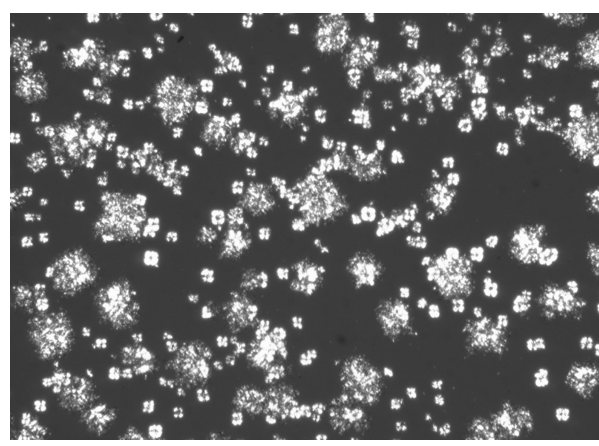

$25 \stackrel{\circ}{\mathrm{C}}$ antes

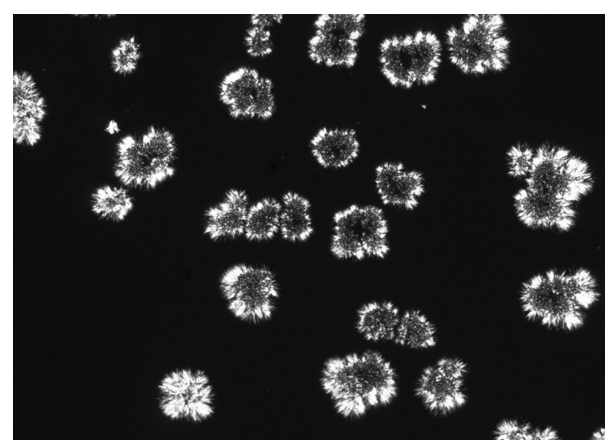

$30 \stackrel{\circ}{C}$ antes

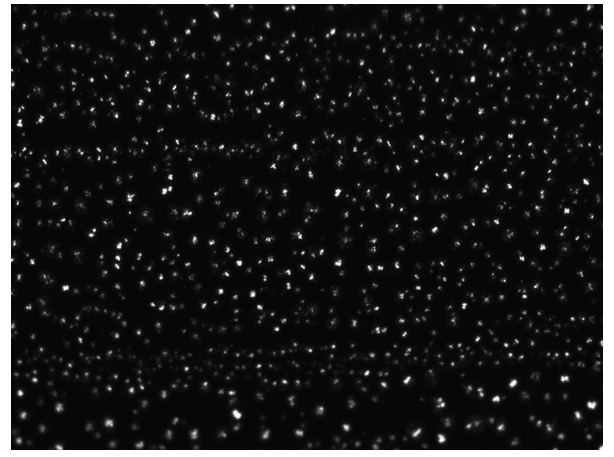

$15^{\circ} \mathrm{C}$ após

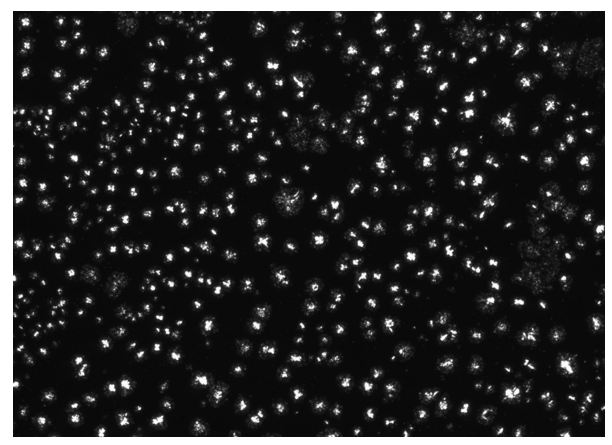

$20 \stackrel{\circ}{C}$ após

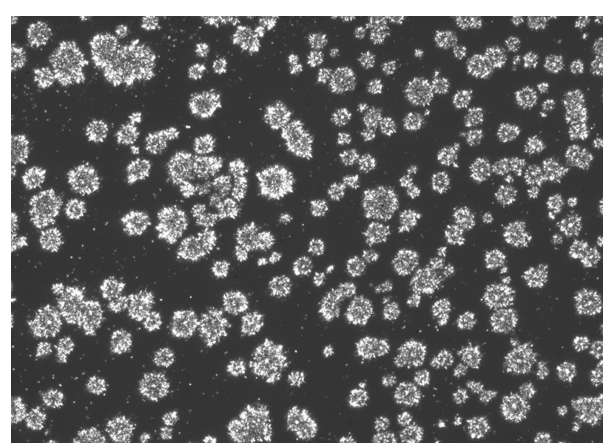

$25^{\circ} \mathrm{C}$ após

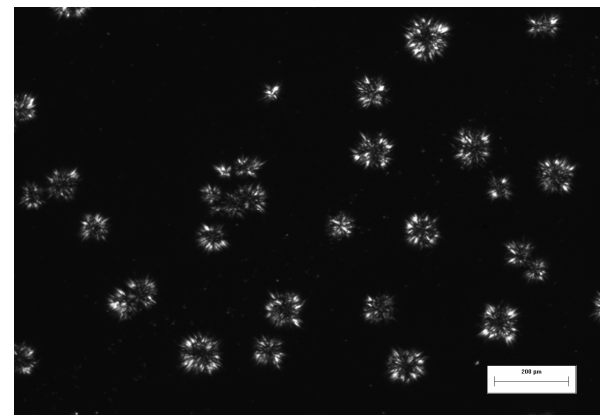

$30 \stackrel{\circ}{C}$ após

Figura 16. Imagens da cristalização da banha antes e após a interesterificação química. A barra representa $200 \mu \mathrm{m}$. 
Em relação ao efeito da presença do óleo de soja na formação da rede cristalina, os resultados indicam que a tendência de cristalização da banha se mantém nas misturas, porém a cristalização é dificultada pelo efeito da diluição com óleo de soja. Assim, em cada temperatura de análise, houve tendência a aumentar o diâmetro dos cristais à medida que aumentava a participação do óleo de soja na mistura, pois a velocidade de cristalização era cada vez menor. Da mesma forma, o número de cristais apresentou tendência a diminuir (Figuras 17 e 18). Enquanto a banha isoladamente apresentou estrutura cristalina a $30 \stackrel{\circ}{ }$, as misturas com 20 e $40 \%$ de óleo de soja não cristalizaram a esta temperatura.

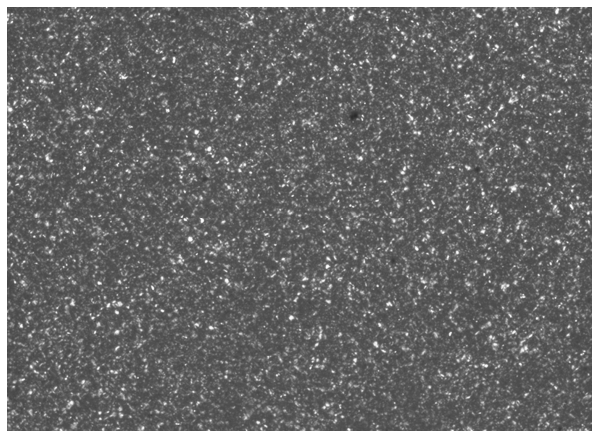

$15 \stackrel{\circ}{\circ}$ antes

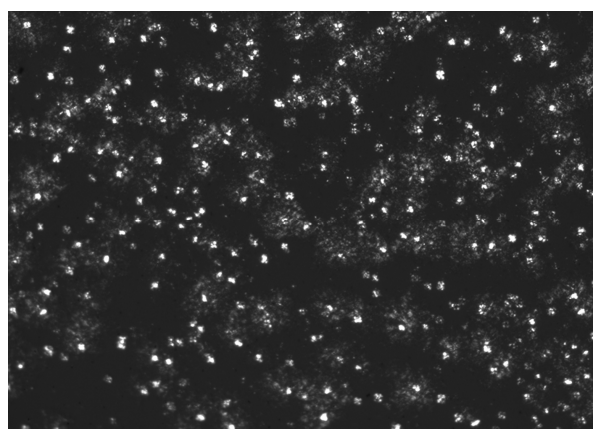

$20^{\circ} \mathrm{C}$ antes

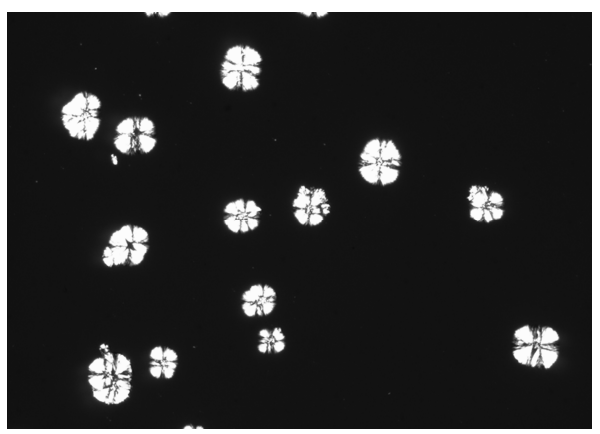

$25^{\circ} \mathrm{C}$ antes

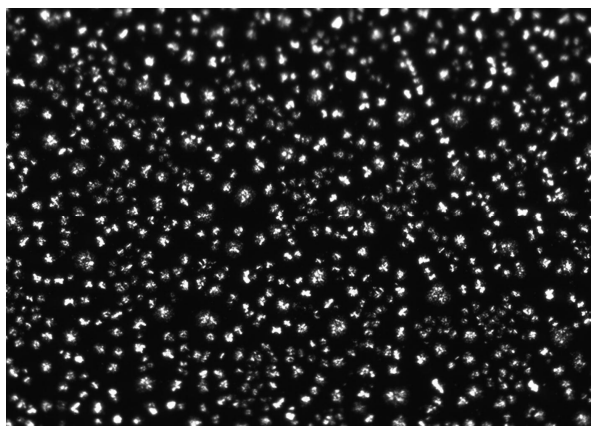

$15^{\circ} \mathrm{C}$ após

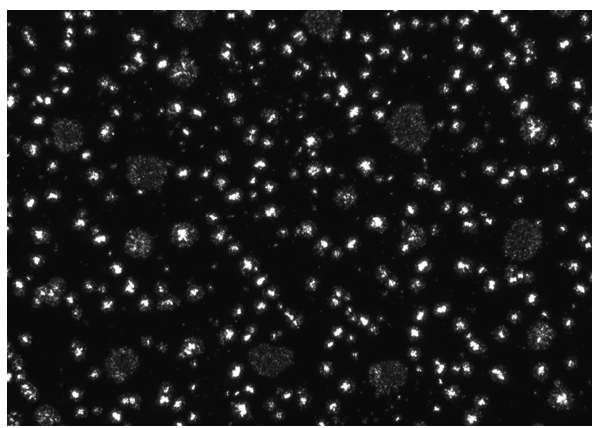

$20{ }^{\circ} \mathrm{C}$ após

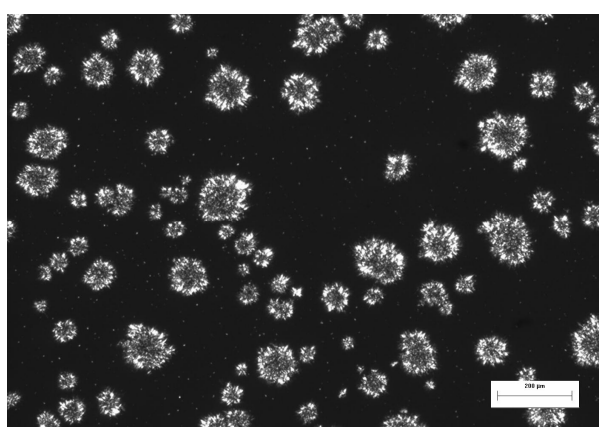

$25^{\circ} \mathrm{C}$ após

Figura 17. Imagens da cristalização da mistura de $80 \%$ de banha com $20 \%$ de óleo de soja antes e após a interesterificação química. A barra representa $200 \mu \mathrm{m}$. 


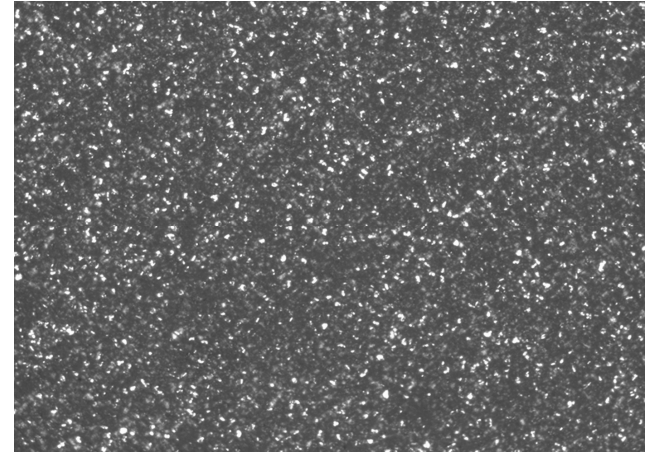

$15^{\circ} \mathrm{C}$ antes

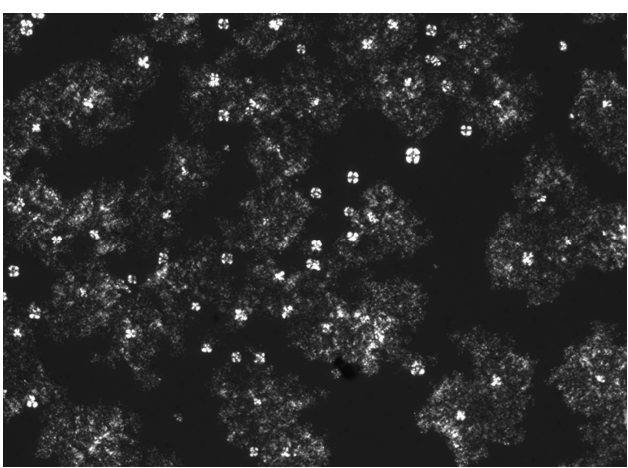

$20^{\circ} \mathrm{C}$ antes

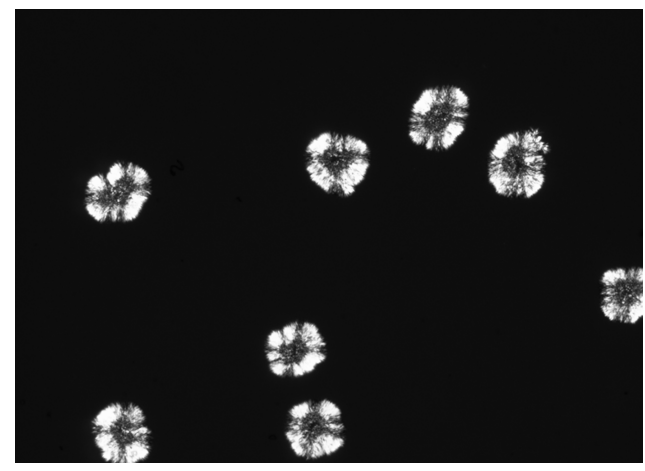

$25^{\circ} \mathrm{C}$ antes

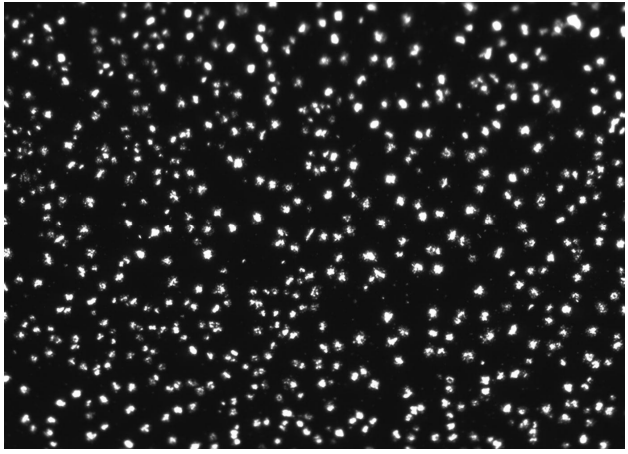

$15^{\circ} \mathrm{C}$ após

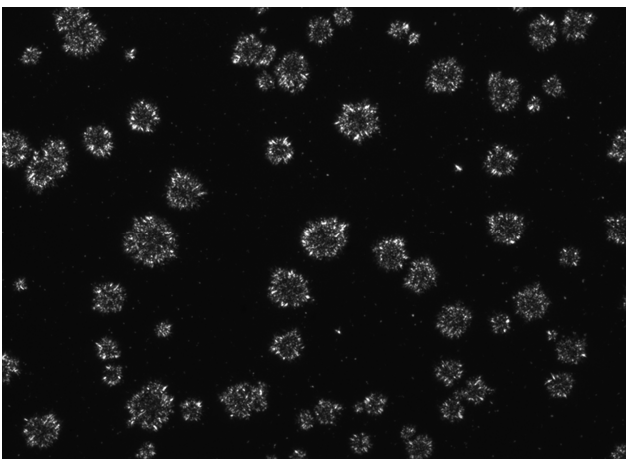

$20^{\circ} \mathrm{C}$ após

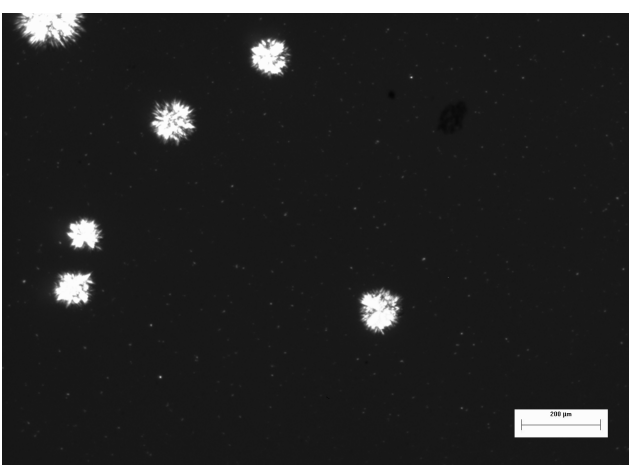

$25^{\circ} \mathrm{C}$ após

Figura 18. Imagens da cristalização da mistura de $60 \%$ de banha com $40 \%$ de óleo de soja antes e após a interesterificação química. A barra representa $200 \mu \mathrm{m}$.

A comparação dos resultados dos diâmetros médios e do número de cristais das amostras interesterificadas com as originais mostra a alteração na estrutura cristalina provocada pelo rearranjo ao acaso. As amostras interesterificadas apresentaram tendência à formação de cristais de maior diâmetro e em menor número que as originais às temperaturas de 15 e $20^{\circ} \mathrm{C}$ (Tabelas 19 e 20). Por outro lado, às temperaturas de 25 e $30{ }^{\circ} \mathrm{C}$ os cristais tenderam a apresentar menores 
diâmetros que as originais. Estes efeitos podem ser decorrentes da formação em maior quantidade de triacilgliceróis trissaturados e dissaturados após a interesterificação, que apresentam maiores pontos de fusão (SILVA \& GIOIELLI, 2006). Deve ser ressaltado que os altos valores do desvio-padrão em relação à média do diâmetro dos cristais, ou seja, altos coeficientes de variação são característicos de gorduras cristalizadas quando observadas em microscopia sob luz polarizada (ROSSEAU et al., 1996, RODRIGUES et al., 2003, DIAZ GAMBOA \& GIOIELLI, 2006).

Tabela 19. Diâmetro médio dos cristais das misturas de banha e óleo de soja antes e após a interesterificação química.

\begin{tabular}{|c|c|c|c|c|}
\hline \multicolumn{5}{|c|}{ Diâmetro dos cristais $(\mu \mathrm{m})$} \\
\hline & \multicolumn{4}{|c|}{ Temperatura $\left({ }^{\circ} \mathrm{C}\right)$} \\
\hline & 15 & 20 & 25 & 30 \\
\hline Banha:Soja & \multicolumn{4}{|c|}{ Antes de interesterificação } \\
\hline $100: 0$ & $7,31 \pm 4,15$ & $7,43 \pm 5,39$ & $45,21 \pm 25,68$ & $197,50 \pm 48,64$ \\
\hline $80: 20$ & $6,72 \pm 3,76$ & $8,94 \pm 6,54$ & $116,26 \pm 18,28$ & - \\
\hline $60: 40$ & $7,48 \pm 4,28$ & $18,47 \pm 8,03$ & $181,31 \pm 13,91$ & - \\
\hline Banha:Soja & \multicolumn{4}{|c|}{ Após a interesterificação } \\
\hline $100: 0$ & $9,75 \pm 4,05$ & $13,02 \pm 6,99$ & $74,91 \pm 31,85$ & $126,09 \pm 27,04$ \\
\hline $80: 20$ & $20,35 \pm 6,71$ & $50,26 \pm 31,92$ & $80,58 \pm 31,86$ & - \\
\hline $60: 40$ & $17,05 \pm 6,72$ & $68,96 \pm 52,12$ & $115,29 \pm 21,96$ & - \\
\hline
\end{tabular}


Tabela 20. Número de cristais das misturas de banha e óleo de soja antes e após a interesterificação química.

\begin{tabular}{|c|c|c|c|c|}
\hline \multicolumn{5}{|c|}{ Número de cristais } \\
\hline & \multicolumn{4}{|c|}{ Temperatura $\left({ }^{\circ} \mathrm{C}\right)$} \\
\hline & 15 & 20 & 25 & 30 \\
\hline Banha:Soja & \multicolumn{4}{|c|}{ Antes da interesterificação } \\
\hline 100:0 & 5877 & 1820 & 252 & 25 \\
\hline $80: 20$ & 5994 & 912 & 13 & - \\
\hline $60: 40$ & 3093 & 311 & 8 & - \\
\hline Banha:Soja & \multicolumn{4}{|c|}{ Após a interesterificação } \\
\hline 100:0 & 830 & 636 & 159 & 28 \\
\hline $80: 20$ & 671 & 306 & 74 & - \\
\hline $60: 40$ & 647 & 82 & 6 & - \\
\hline
\end{tabular}

A Tabela 21 apresenta os resultados da dimensão fractal da banha e suas misturas binárias com óleo de soja antes e após a interesterificação química.

A dimensão fractal variou de 1,08 a 1,80. A dimensão fractal, quando determinada pelo método de caixas, depende do grau de preenchimento da estrutura cristalina e da forma dos cristais obtidos (SIMÕES \& GIOIELLI, 1999). Assim sendo, não foi possível relacionar as diferenças observadas da dimensão fractal entre as amostras como sendo decorrentes da temperatura de cristalização ou da presença do óleo de soja. Contudo, quando a forma dos cristais é semelhante, como ocorre com as amostras à temperatura de $15{ }^{\circ} \mathrm{C}$, a dimensão fractal apresentou tendência a diminuir após a interesterificação, pois o grau de preenchimento da estrutura cristalina vai gradualmente se tornando menor à medida que aumenta a participação do óleo de soja na mistura rearranjada. A dimensão fractal da rede cristalina é uma medida da ordem na distribuição espacial da massa sólida na rede, sendo que maiores valores para a dimensão fractal representam uma distribuição mais organizada (WRIGHT et al., 2000). Assim sendo, os valores da dimensão fractal decorrente do resfriamento rápido a $15^{\circ} \mathrm{C}$ apresentaram tendência a diminuir pela maior quantidade de óleo de soja na mistura rearranjada, que por ser Roberta Claro da Silva - Doutorado - FCF 
líquido tornou menor a ordem de empacotamento dos elementos microestruturais. Por outro lado, a formação de aglomerados de cristais e esferulitos de maior diâmetro, o que foi observado às temperaturas de 20 e $25^{\circ} \mathrm{C}$, provoca a variação da dimensão fractal, assim como foi observado por Marangoni (2005), ao estudar a dimensão fractal de óleo de palma a diversos conteúdos de gordura sólida. A dimensão fractal determinada por microscopia de diversas gorduras comestíveis varia entre 1,47 a 1,88 , estando, entre estas, a manteiga de cacau ( $D=1,56)$, a gordura do leite não interesterificada $(D=1,85)$ e a gordura de palma $(D=1,87)$ (NARINE \& MARANGONI, $1999^{\mathrm{a}, \mathrm{b}}$ ).

As alterações no diâmetro e número dos cristais, assim como na dimensão fractal das amostras interesterificadas podem estar relacionadas à alteração na forma polimórfica dos cristais de banha provocada pelo rearranjo ao acaso, que passam da forma $\beta$ para $\beta$-prima, pois a composição em triacilgliceróis após 0 rearranjo tende a ser heterogênea, com menor participação do ácido palmítico na posição sn-2. Isto melhora a plasticidade dos produtos que utilizam a banha modificada, ocasionando resultados superiores na panificação e na aparência durante o armazenamento . (O'BRIEN, 1998).

Tabela 21. Dimensão fractal dos cristais das misturas de banha e óleo de soja antes e após a interesterificação.

Dimensão fractal

\begin{tabular}{ccccc}
\hline \multicolumn{5}{c}{ Temperatura $\left({ }^{\circ} \mathrm{C}\right)$} \\
\hline Banha:Soja & 15 & \multicolumn{4}{c}{20} & 25 & 30 \\
\hline $100: 0$ & $1,60 \pm 0,01$ & $1,33 \pm 0,04$ & $1,59 \pm 0,01$ & $1,52 \pm 0,03$ \\
$80: 20$ & $1,80 \pm 0,02$ & $1,21 \pm 0,05$ & $1,18 \pm 0,01$ & - \\
$60: 40$ & $1,79 \pm 0,02$ & $1,21 \pm 0,03$ & $1,43 \pm 0,03$ & - \\
\hline Banha:Soja & & Após a interesterificação & \\
\hline $100: 0$ & $1,49 \pm 0,02$ & $1,46 \pm 0,02$ & $1,60 \pm 0,02$ & $1,08 \pm 0,02$ \\
$80: 20$ & $1,62 \pm 0,03$ & $1,27 \pm 0,04$ & $1,20 \pm 0,03$ & - \\
$60: 40$ & $1,50 \pm 0,03$ & $1,10 \pm 0,01$ & $1,15 \pm 0,02$ & - \\
\hline
\end{tabular}




\subsection{CONCLUSÕES}

Houve tendência a aumentar o diâmetro e diminuir o número dos cristais à medida que aumentava a participação do óleo de soja na mistura.

As amostras interesterificadas apresentaram tendência à formação de cristais em menor número e de maior diâmetro que as originais às temperaturas de 15 e 20 ${ }^{\circ} \mathrm{C}$.

O diâmetro médio dos cristais de todas as amostras aumentou com 0 aumento da temperatura, atingindo valores da ordem de $200 \mu \mathrm{m}$. 


\subsection{REFERÊNCIAS BIBLIOGRÁFICAS}

DÍAZ GAMBOA, O.W.; GIOIELLI, L.A. Comportamento de cristalização de lipídios estruturados obtidos a partir de gordura de palmiste e óleo de peixe. Química Nova, v.29, n.4, p.646-653, 2006.

DÍAZ GAMBOA, O.W.; GIOIELLI, L.A. Consistencia de lípidos estructurados a partir de aceite de pescado y grasa de palmiste. Grasas y Aceites, v.54, n.2, p.122-129, 2003a.

DÍAZ GAMBOA, O.W.; GIOIELLI, L.A. Lípidos estructurados obtenidos por interesterificación química y enzimática a partir de aceite de pescado y grasa de semilla de palma. Grasas y Aceites, v.54, n.2, p.161-168, 2003b.

GIOIELLI, L.A. Lipídios estruturados. In: CURI, R.; POMPÉIA, C.; MIYASAKA, C.K.; PROCOPIO, J., eds. Entendendo a gordura: os ácidos graxos. São Paulo: Manole, 2002. p.457-465.

GIOIELLI, L.A.; SIMÕES, I.S.; RODRIGUES, J.N. Crystal morphology and interactions of binary and ternary mixtures of hydrogenated fats. Journal of Food Engineering., v.57, n.4, p.347-355, 2003.

HERRERA, M.; FALABELLA, C.; MELGAREJO, M.; ANON, M. Isothermal crystallization of hydrogenated sunflower oil: 1. nucleation. Journal of the American Oil Chemists' Society. v.75, n.10, p.1273-1280, 1998.

HUI, Y.H., ed. Bailey's industrial oil and fat products. 5ª ed., New York: Wiley, p. 497601, 603-654, 1996.

LARSSON, K.A. Lipids : molecular organization, physical functions and technical applications. Dundee: The Oil Press, 1994.

LEE, K.T.; AKOH, C.C. Characterization of enzymatically syntetized structured lipids containing eicosapentaenoic, docosahexanoic and caprylic acids, Journal of the American Oil Chemists' Society. v.75, n.4, p.495-499, 1998.

MARANGONI, A.G. Fat crystal networks. New York, Marcel Dekker, 854p. 2005.

MARANGONI, A.G. The nature of fractality in fat crystal networks. Trends Food Science Technology. v. 13, n.2, p.37-42, 2002.

MARANGONI, A.G.; HARTEL, R.W. Visualization and structural analysis of fat crystal networks, Food Technology. v. 52, n.9, p. 46-51, 1998.

MARANGONI, A.G.; ROUSSEAU, D. Is plastic fat rheology governed by the fractal nature of the fat crystal network. Journal of the American Oil Chemists' Society. v.73, n.8, p.991-993, 1996. 
NARINE, S.S.; MARANGONI, A.G. Microscopic and rheological studies of fat crystal networks. Journal of Crystal Growth. v.198/199, p.1315-1320, 1999.

NARINE, S.S.; MARANGONI, A.G.; Relating Structure of Fat Crystal Networks to Mechanical Properties: A Review. Food Research International, v.32, n.4, p.227248, 1999.

NARINE, S.S.; MARANGONI, A.G.; Factors influencing the texture of plastic fats, INFORM, v.10, n.6, p.565-570, 1999.

NARINE, S.S.; MARANGONI, A.G. Fractal nature of fat crystal networks. Physical Review E., v.59, n.17, p.1908-1920,1999.

O'BRIEN, R.D. Fats and oils - Formulating and processing for applications. Lancaster, Pa. Technomic Pub. Co., 1998. p.7-10, 33-36, 98-108.

OSBORN, H.T.; AKOH, C.C. Structured lipids - novel fats with medical, nutraceutical, and food applications. Comprehensive Reviews In: Food Science and Food Safety, v.1, n.3, p.93-103. 2002.

RODRIGUES, J.N.; ANTON, C.; GIOIELLI, L.A. Cristalização de lipídios estruturados obtidos a partir de gordura do leite e óleo de milho. Revista Brasileira de Ciências Farmacêuticas. v.39, n.1, p.93-103, 2003.

RODRIGUES, J.N.; GIOIELLI, L.A. Chemical interesterification of milkfat-corn oil blends. Food Research International. v.36, n.2, p.149-159, 2003.

ROUSSEAU, D.; FORESTIERE, K., HILL, A.R.; MARANGONI, A.G. Restructuring butterfat through blending and chemical interesterification. 1. Melting behavior and triacylglycerol modifications. Journal of the American Oil Chemists' Society. v.73, n.8, p.963-972, 1996.

ROUSSEAU, D.; MARANGONI A.G.; JEFFREY, K.R. The influence of chemical interesterification on the physicochemical proprerties of complex fat systems 2 . morphology and polymorphism. Journal of the American Oil Chemists' Society. v.75, n.12, p.1833-1839, 1998.

SATO, K. Crystallization behaviour of fats and lipids - a review. Chemical Engineering Science, v.56, n.7, p.2255-2265, 2001.

SILVA, R.C.; GIOIELLI, L.A. Propriedades físicas de lipídios estruturados obtidos a partir de banha e óleo de soja, Revista Brasileira de Ciências Farmacêuticas. v.42, n.2, p.223-235, 2006.

SIMÕES, I.S.; GIOIELLI, L.A. Crystal morphology of binary and ternary mixtures of hydrogenated fats and soybean oil. Brazilian Archives of Biology and Technology. v.43, n.2, p.241-248, 2000. 
SIMÕES, I.S.; GIOIELLI, L.A. Cristalização e polimorfismo de gorduras. Óleos Grãos, v.8, n.50, p.20-29, 1999.

SIMÕES, I.S.; GIOIELLI, L.A. Microscopia da cristalização parcial de gorduras hidrogenadas e óleo de soja. Revista Brasileira de Ciências Farmacêuticas, v.35, n.2, p.259-266, $1999^{\text {a }}$.

SOTERO-SOLIS, V.E.; GIOIELLI, L.A. Estrutura cristalina de las grasas hidrogenadas del aceite de castaña de Brasil (Bertholletia Excelsa). Alimentaria, v.38, n.322, p.131-137, 2001.

STANLEY, D.W.; AGUILERA, J.M.; BAKER, K.W.; JACKMAN, R.L. Structure/property relationship of foods as affected by processing and storage. In: RAO, M.A., HARTEL, R.W., eds. Phase/ State transitions foods. New York: Marcel Dekker,. p. 1-56. 1998

TIMMS, R.E. Em Developments in oils and fats: HAMILTON, R.J., ed. Blackie London, 1995, 204p.

WILLIS, W.M.; LENCKI, R.W.; MARANGONI, A.G. Lipid modification strategies in the production of nutritionally functional fats and oils. Critical Reviews in Food Science and Nutrition, v.38, n.8, p.639-674, 1998.

WILLIS, W.M.; MARANGONI, A.G. Assessment of lipase and chemically catalysed lipid modification strategies for the production of structured lipids. Journal of the American Oil Chemists' Society. v.76, n.4, p.443-450, 1999.

WRIGHT, A.J.; HARTEL, R.W.; NARINE, S.S.; MARANGONI, A.G. The effect of minor components on milk fat cristallization. Journal of the American Oil Chemists' Society. v.77,n.5, p.463-475, 2000

WRIGHT, A.J.; SCANLON, M.G.; HARTEL, R.W.; MARANGONI, A.G. Rheological Properties of Milk Fat and Butter Journal of Food Science. v.66, n.8, p.1056-1071, 2001. 


\section{Propriedades físicas das misturas e dos}

lipídios estruturados obtidos a partir de banha e óleo de soja por interesterificação enzimática

SILVA, R.C.; COTTING, L.N.; POLTRONIERI, T.P.; BALCÃO, V.M., GIOIELLI, L.A. Physical properties of structured lipids from lard and soybean oil produced by enzymatic interesterification. Enviado para publicação em 03/08/2007. 


\section{RESUMO}

O objetivo deste trabalho foi avaliar as propriedades físicas das misturas entre banha e óleo de soja modificadas pela interesterificação enzimática catalisada por duas diferentes lipases comerciais, a $\mathrm{AY} 30^{\mathrm{TM}}$ proveniente do microorganismo Candida cylindracea e a $\mathrm{M}^{\mathrm{T}}{ }^{\mathrm{TM}}$ proveniente do microorganismo Mucor circinelloides. A banha apresentou ponto de amolecimento de $31,8{ }^{\circ} \mathrm{C}$ antes da interesterificação e este valor foi reduzido a 29,1 ํㅡ e 28,8 으 após a interesterificação com as lipases $\mathrm{AY} 30^{\mathrm{TM}}$ e $\mathrm{M} 10^{\mathrm{T} M}$, respectivamente. A consistência da banha diminuiu após a interesterificação enzimática com ambas lipases, e a redução foi maior quando o catalisador utilizado foi a lipase $\mathrm{M} 10^{\mathrm{TM}}$. Este resultado se deve à especifidade das posições $s n-1,3$ da lipase M10 TM. A banha apresentou menor conteúdo de gordura sólida após a interesterificação, e essa redução foi mais efetiva quando a reação foi catalisada pela lipase $\mathrm{M} 10^{\mathrm{TM}}$. A banha não interesterificada apresentou conteúdo de gordura sólida de $31,3 \%$ a $10{ }^{\circ} \mathrm{C}$, que foi reduzido a 23,8 \% and 19,9 \% após a interesterificação com as lipases AY30 e M10, respectivamente. A banha e suas misturas binárias com o óleo de soja foram afetadas pela interesterificação enzimática e pela diluição com o óleo de soja. 


\subsection{INTRODUÇÃO}

Lipídios estruturados podem ser definidos como triacilgliceróis reestruturados ou modificados para alterar a composição em ácidos graxos e/ou sua distribuição nas moléculas de glicerol, por métodos químicos, enzimáticos ou de engenharia genética (LEE \& AKOH, 1998; OSBORN \& AKOH, 2002). Lipídios estruturados são normalmente misturas de triacilgliceróis modificadas para apresentar composição particular em ácidos graxos ou triacilgliceróis, a fim de obter alguma propriedade desejável, como o valor calórico reduzido ou o ponto de fusão alterado. Também podem apresentar características favoráveis quanto à resposta imune, síntese de eicosanóides e ações antiinflamatórias (AKOH \& MOUSSATA, 1998).

A interesterificação química é uma reação ao acaso que produz completa randomização dos ácidos graxos nos triacilgliceróis (WILLIS \& MARANGONI, 1999;). Sob a perspectiva de custo e aplicação em larga escala, a interesterificação química parece ser o método mais atrativo. Contudo, sob a perspectiva de produzir lipídios com composições muito específicas para aplicações funcionais e medicinais, os métodos de interesterificação enzimática são mais interessantes (WILLIS et al., 1998; BALCÃO et al., 1996).

A interesterificação enzimática tem a vantagem de permitir grande controle sob a distribuição posicional dos ácidos graxos do produto final, devido à seletividade e regioespecifidade das lipases (WILLIS \& MARANGONI, 1999; BALCÃO \& MALCATA, 2002; BALCÃO \& MALCATA, 1998).

As lipases naturalmente catalisam a hidrólise dos triacilgliceróis em monoacilgliceróis, diacilgliceróis, ácidos graxos livres e glicerol na presença de água (BALCÃO et al., 1996). Além da reação de transesterificação, as lipases podem também catalisar as reações de esterificação direta, a acidólise e a alcoólise sob condições controladas de água (LEE \& AKOH, 1998; BALCÃO et al., 1996).

Os processos de bio-conversão enzimática têm sido bastante utilizados na produção, transformação e valorização de matérias primas. Importantes aplicações têm sido realizadas nas indústrias alimentícias, farmacêuticas e no desenvolvimento de propostas ambientais. A maioria das reações enzimáticas é realizada em reatores por bateladas, apresentando alguns inconvenientes como altos custos operacionais, 
baixa produtividade, alta variação na qualidade dos produtos obtidos e problemas de remoção da enzima (RIOS et al., 2004).

Visando a obtenção de reações com maior uniformidade tecnológica e viabilidade econômica, a utilização de enzimas na forma imobilizada permite considerável aumento na estabilidade e maior diversidade de aplicação, de fundamental importância para o desenvolvimento de processos associados à bioconversão (HILAL \& NIGMATULLIN, 2004). A utilização de enzimas imobilizadas confere maior produtividade, facilidade na automação de processos e operações contínuas, controle preciso da extensão das reações, facilidade de separação dos produtos obtidos, estabilização da atividade enzimática, facilidade de recuperação e reutilização das enzimas (SWAISGOOD, 1991).

A interesterificação enzimática tem sido muito utilizada como ferramenta para a modificação de diversos lipídios, como os óleos vegetais e de peixe (SENANAYAKE \& SHAHIDI, 1999, 2002; XU et al., 2000; PAEZ et al., 2002) e gorduras animais, especialmente banha e gordura do leite (BALCÃO \& MALCATA, 2002, 1998, 1997; SAHIN et al., 2005; YANG et al., 2003; NIELSEN et al., 2006). Produtos com aplicações específicas são produzidos por interesterificação enzimática, como os substitutos da manteiga de cacau, substitutos da gordura do leite humano, óleo de peixes modificados e margarinas, entre outros (SAHIN et al., 2005; YANG et al., 2003; NIELSEN et al., 2006).

Diversas lipases são encontradas comercialmente, e estas podem ter distintas origens, microbiana, de vegetais ou até animal. Dentre estas, as lipases microbianas,são descritas como as mais interessantes (XU, 2000; BALCÃO et al., 1996).

Para se determinar a aplicação dos lipídios estruturados em formulações de alimentos é indispensável conhecer suas propriedades físicas, como propriedades térmicas, reologia, tendência de cristalização, textura e aparência (OSBORN \& $\mathrm{AKOH}, 2002)$. Alguns pesquisadores utilizaram a metodologia de "dropping point" para verificar a ocorrência da interesterificação (LIST et al., 1995). Entretanto, este método não aparenta ser o mais indicado para esta finalidade, pois não fornece resultados confiáveis. ROUSSEAU e seus colaboradores (1996) não obtiveram correlação linear entre a adição de canola em misturas e a redução linear do "dropping point". 
O conteúdo de gordura sólida tem grande influência na determinação da aplicação de óleos e gorduras. É responsável por muitas características finais do produto, incluindo a aparência geral, facilidade de embalagem, propriedades organolépticas, espalhabilidade e a exsudação de óleo em alimentos.O conteúdo de gordura sólida também pode ser usado para determinar a compatibilidade entre diferentes gorduras e mudanças no percentual de sólidos em diferentes proporções das gorduras (RODRIGUEZ et al., 2001; NOOR LIDA \& ALI, 1998).

A textura de lipídios estruturados pode ser medida pelo teste de penetração com cone acrílico, usando o equipamento INSTRON ${ }^{\mathrm{TM}}$ ou analisador de textura. Dureza e coesividade são importantes parâmetros de textura de alimentos espalháveis e produtos de chocolate. Caso um lipídio estruturado não tenha boa espalhabilidade, ele terá valores baixos de coesividade (OSBORN \& AKOH, 2002). LOHMAN \& HARTEL (1994) demonstraram existir forte relação entre o conteúdo de gordura sólida e a dureza em manteiga de cacau.

O leite humano contém cerca de $3-5 \%$ de lipídios totais, dentre os quais $98 \%$ são de triacilgliceróis, $1 \%$ de fosfolipídios e $0,5 \%$ de esteróis (JENSEN, 1996). Os triacilgliceróis são compostos principalmente por ácidos graxos de cadeia longa (cerca de $90 \%$ dos ácidos graxos no leite humano). A estrutura da gordura do leite humano é única e possui em sua maior parte ácidos graxos de cadeia longa como os ácidos oléico ( 30-35\%), palmítico ( 20-30\%) e linoléico ( 7-14\%). O ácido palmítico representa a maior proporção dos ácidos saturados na gordura do leite humano, sendo que, $70 \%$ estão esterificados na posição sn- 2 dos triacilgliceróis. As posições sn-1 e sn-3 são principalmente ocupadas pelos ácidos graxos insaturados, ao contrário do que ocorre em óleos vegetais e também na gordura do leite bovino (XU et al., 2002; INNIS et al.,1995; BALCÃO \& MALCATA, 2002). A banha é a única gordura que possui estrutura similar à do leite humano.

Vários estudos foram conduzidos na expectativa de obter um sucedâneo da gordura do leite humano (MUKHERJEE \& KIEWET, 1998; YANG et al., 2003a; YANG et al., 2003b; SCHMID et al., 1999; CHRISTENSEN \& HOLMER, 1993; YANG \& FRUEKIELD, 2003; SCHMID et al., 1999).

O objetivo deste trabalho foi produzir lipídios estruturados sucedâneos da gordura do leite humano por interesterificação enzimática de banha e suas misturas com óleo de soja, utilizando como catalisador duas lipases comerciais provenientes 
dos microorganismos Candida cylindracea e Mucor circinelloides, e também caracterizar as propriedades físicas destes lipídios estruturados obtidos.

\subsection{MATERIAL E MÉTODOS}

\subsubsection{Material}

A banha e o óleo de soja foram obtidos no comércio local (São Paulo). As lipases comerciais provenientes dos microorganismos Candida cylindracea (AY30 ${ }^{\mathrm{TM}}$ ) e Mucor circinelloides (M10 ${ }^{\mathrm{TM}}$ ) foram gentilmente doadas pela empresa Amano Pharmaceuticals Inc. (Nagoya, Japão). Todos os demais solventes e reagentes utilizados foram de grau analítico.

\subsubsection{Métodos}

\subsubsection{Mistura}

Três misturas binárias de banha e óleo de soja foram preparadas nas seguintes proporções 80:20, 60:40 e 50:50 (p/p). As misturas (150g) foram preparadas após a completa fusão das gorduras a $70-80 \stackrel{\circ}{\circ} \mathrm{C}$ por $30 \mathrm{~min}$ sob agitação constante, e armazenadas sob refrigeração a $4 \stackrel{\circ}{\circ}$.

\subsubsection{Reação de interesterificação}

A reação de interesterificação foi conduzida no laboratório de Bioengenharia e Química Biofarmacêutica da Universidade Fernando Pessoa - Porto - Portugal. A reação de interesterificação enzimática foi realizada sob agitação constante, sob pressão reduzida a $60 \stackrel{\circ}{\circ}$, em reator de vidro. Cada mistura foi acondicionada no reator por 10 minutos para alcançar o equilíbrio térmico. Após esse período, foram adicionados cerca de $1 \%$ da enzima, o reator foi fechado, e o "head space" completado com nitrogênio. A mistura foi agitada $(750 \mathrm{rpm})$ por 24 horas. Alíquotas foram retiradas em intervalos regulares de tempo para a determinação de ácidos graxos. Ao final da reação a mistura foi filtrada utilizando papel de filtro e armazenada a $-80{ }^{\circ} \mathrm{C}$. 


\subsubsection{Composição em ácidos graxos}

A análise da composição em ácidos graxos foi realizada após a conversão dos triacilgliceróis em ésteres metílicos (FAME), de acordo com a metodologia proposta por HARTMAN \& LAGO (1973).

A análise da composição em ácidos graxos foi realizada em cromatógrafo a gás Varian GC, modelo $3400 C X$, equipado com detector de ionização de chama e "Workstation Star Chromatography". Foi utilizada coluna capilar de sílica fundida CP WAX 52 CB (Chrompack Minnesota MN, USA), com 30 metros de comprimento $x$ $0,25 \mathrm{~mm}$ de diâmetro interno e contendo $0,25 \mu \mathrm{m}$ de polietilenoglicol dentro da coluna. As condições foram: injeção split, razão de 50:1; temperatura da coluna: 150 ${ }^{\circ} \mathrm{C}$ por $5 \mathrm{~min}$, programada até $215{ }^{\circ} \mathrm{C}$ numa razão de $3 \stackrel{\circ}{\mathrm{C}} / \mathrm{min}$; gás de arraste: hélio, numa vazão de $1,5 \mathrm{~mL} / \mathrm{min}$; gás make up: hélio a $30 \mathrm{~mL} / \mathrm{min}$; temperatura do injetor $250{ }^{\circ} \mathrm{C}$; temperatura do detector $280^{\circ} \mathrm{C}$. A composição qualitativa foi determinada por comparação dos tempos de retenção dos picos com os respectivos padrões de ácidos graxos. A composição quantitativa foi realizada por normalização de área, sendo expressa como porcentagem em massa, de acordo com o método oficial AOCS Ce 1-62 (AOCS, 1997a). Todas as amostras foram analisadas em duplicata e os valores apresentados correspondem às médias destes valores.

\subsection{6 Índice de lodo}

O índice de iodo foi calculado a partir da composição em ácidos graxos, segundo o método Cd 1-25 (AOCS, 1997b).

\subsubsection{Ponto de amolecimento}

O ponto de amolecimento, utilizando tubo capilar aberto, foi determinado segundo o método Cc 3-25, (AOCS, 1997c). Todas as amostras foram analisadas em triplicata e os valores apresentados correspondem às médias destes valores.

\subsubsection{Consistência}

A análise de consistência foi efetuada pelo teste de penetração com cone

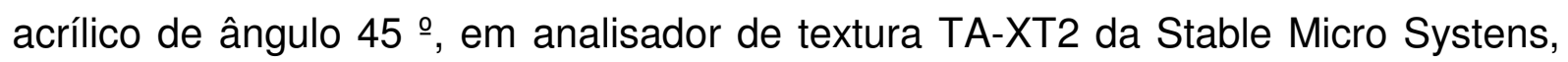
controlado por microcomputador (DÍAZ GAMBOA \& GIOIELLI, 2003a, 2003b).

Os testes foram conduzidos nas seguintes condições: 
- $\quad$ Determinação da força em compressão

- Distância: 10,0 mm

- $\quad$ Velocidade: $2,0 \mathrm{~mm} / \mathrm{s}$

Tempo: $5 \mathrm{~s}$

Triplicata

Para realizar a conversão dos dados de penetração em um parâmetro independente do peso e do tipo de cone, foi utilizada a equação proposta por HAIGHTON (1959), para o cálculo do "yield value":

$$
\mathrm{C}=\frac{\mathrm{K} \times \mathrm{W}}{\mathrm{p}^{1.6}}
$$

Onde:

$\mathrm{C}=$ "yield value", em $\mathrm{gf} / \mathrm{cm}^{2}$

$\mathrm{K}=$ fator que depende do ângulo do cone (para ângulo de 45으 $\mathrm{K}$ é igual a 4.700)

$\mathrm{W}$ = peso total do sistema, em g (para penetrômetro de cone)

$\mathrm{p}=$ profundidade de penetração

Considerando as condições dos testes de compressão realizados com o analisador de textura, a equação assume a seguinte forma:

$$
C=4700 . W / 100^{1,6}
$$

Onde:

$$
\begin{aligned}
& C=\text { "yield value", em } \mathrm{gf} / \mathrm{cm}^{2} \\
& W=\text { força em compressão, em gf, para tempo = 5s. }
\end{aligned}
$$

As amostras de gordura foram aquecidas à temperatura de $70-80^{\circ} \mathrm{C}$ em forno de microondas para a completa fusão dos cristais, sendo acondicionadas em béqueres de $50 \mathrm{~mL}$ (Pyrex, USA). O condicionamento foi efetuado por 24 horas em geladeira comum $\left(5-8^{\circ} \mathrm{C}\right)$ e em seguida por 24 horas em estufa com temperatura controlada (temperatura de análise $\pm 0,5^{\circ} \mathrm{C}$ ). A medida foi realizada em triplicata, e os valores apresentados correspondem às médias dos três valores. 


\subsubsection{Conteúdo de Gordura Sólida}

O conteúdo de gordura sólida foi determinado por ressonância magnética nuclear, utilizando aparelho Maran Ultra Bench Top NMR de $20 \mathrm{MHz}$ (Oxford Instruments, England), de acordo com as normas da "American Oil Chemists' Society", método Cd 16b-93. (AOCS, 1999). Todas as amostras foram analisadas em duplicata e os valores apresentados correspondem às médias destes valores.

\subsubsection{Análise estatísitica}

Os resultados referentes ao ponto de amolecimento, consistência e conteúdo de gordura sólida foram analisados estatisticamente por regressão múltipla (Hare, 1974) representada pela seguinte equação:

$$
Y=\beta_{1} x_{1}+\beta_{2} x_{2}+\beta_{12} x_{1} x_{2}
$$

onde: $Y=$ resposta;

$\beta=$ coeficientes gerados por regressão múltipla;

$X=$ proporção do componente.

O software Statistics 7.0 - StatSoft foi utilizado para gerar os coeficientes do modelo, apresentando os níveis de significância, coeficientes de determinação e análise de variância. O nível de significância avaliado foi de $5 \%(p=0,05)$. 


\subsection{RESULTADOS E DISCUSSÃO}

\subsubsection{Composição em ácidos graxos}

A composição e distribuição dos ácidos graxos nas cadeias de triacilgliceróis em leite humano e nas fórmulas artificiais têm sido alvo de muitos estudos dos pesquisadores nos últimos anos. O substituto da gordura do leite humano deve ter a composição dos ácidos graxos e também a estrutura dos triacilgliceróis semelhante à gordura do leite humano (AKIMMOTO et al., 1999; CHRISTENSEN \& HOLMER, 1993; YANG et al., 2003).

As composições em ácidos graxos da banha e do óleo de soja estão de acordo com a literatura consultada (O'BRIEN, 1998; CODEX, 1999; BRASIL, 1999; DAVENEL et al.,1999; GLÄSER et al., 2004).

A composição em ácidos graxos da banha varia de acordo com a raça, sexo, dieta e idade do animal. Sendo assim, o grau de saturação da banha depende principalmente da quantidade e da composição de gordura da dieta do suíno (O' BRIEN, 1998).

Os principais ácidos graxos presentes na banha foram o ácido oléico, que apresenta $41 \%$ do total, seguido pelo ácido palmítico (25\%), ácido linoléico (13\%) e ácido esteárico (13\%). Os ácidos graxos saturados da banha constituem cerca de $40 \%$ do total de ácidos graxos.

A ingestão adequada de ácidos graxos essenciais (ácidos linoléico e linolênico) é muito importante para recém-nascidos. Desta forma, fórmulas infantis devem ter uma proporção de ácidos linoléico/linolênico entre 5 e 15 (NIELSEN et al., 2006). NIELSEN et al. (2006) encontraram no leite humano a proporção 18:2/18:3 de 14 (2006). Em seus estudos, SILVA et al. (2007) encontraram a proporção de 15,2 no leite humano de mães brasileiras. Neste trabalho, apenas as amostras que continham mais de $40 \%$ de óleo de soja alcançaram esta proporção (Tabela 22).

A FAO/WHO e o European Union Committee recomendam uma proporção mínima de 1 para ácidos graxos poliinsaturados/saturados (PUFA/SFA). Esta proporção PUFA/SFA nas misturas de banha e óleo de soja variou entre 0,3 a 1,6. A banha possui baixos teores de ácidos graxos poliinsaturados na sua composição 
e esta proporção pode ser alterada pela incorporação de $40 \%$ de óleo de soja (Tabela 22).

A interesterificação não afeta o grau de saturação dos ácidos graxos e não causa isomeração. Nossos resultados demonstram que nenhuma alteração significativa ocorreu após a interesterificação no perfil de ácidos graxos das amostras. 
Tabela 22. Composição em ácidos graxos da banha, óleo de soja e suas misturas binárias antes e após a interesterificação

\begin{tabular}{|c|c|c|c|c|c|c|c|c|c|c|c|c|c|c|c|}
\hline Ac. Graxo & $\begin{array}{l}\text { Banha } \\
\text { (Antes) }\end{array}$ & $\begin{array}{l}\text { Banha } \\
\text { (AY30) }\end{array}$ & $\begin{array}{l}\text { Banha } \\
\text { (M10) }\end{array}$ & $\begin{array}{c}\text { 80-20 } \\
\text { (Antes) }\end{array}$ & $\begin{array}{c}80-20 \\
(A Y 30)\end{array}$ & $\begin{array}{l}80-20 \\
\text { (M10) }\end{array}$ & $\begin{array}{c}60-40 \\
\text { (Antes) }\end{array}$ & $\begin{array}{c}60-40 \\
\text { (AY30) }\end{array}$ & $\begin{array}{l}60-40 \\
\text { (M10) }\end{array}$ & $\begin{array}{c}50-50 \\
\text { (Antes) }\end{array}$ & $\begin{array}{c}50-50 \\
(A Y 30)\end{array}$ & $\begin{array}{l}50-50 \\
\text { (M10) }\end{array}$ & $\begin{array}{c}\text { Oleo de } \\
\text { soja } \\
\text { (Antes) }\end{array}$ & $\begin{array}{l}\text { Oleo de } \\
\text { soja } \\
\text { (AY 30) }\end{array}$ & $\begin{array}{c}\text { Oleo de } \\
\text { soja } \\
\text { (M10) }\end{array}$ \\
\hline $14: 0$ & $1,5 \pm 0,02$ & $1,5 \pm 0.01$ & $1,5 \pm 0,00$ & $1,20 \pm 0,00$ & $1,0 \pm 0,00$ & $1,1 \pm 0,00$ & $0.8 \pm 0,12$ & $0,8 \pm 0,00$ & $0.8 \pm 0,00$ & $1,0 \pm 0,04$ & $0,9 \pm 0,02$ & $0,8 \pm 0,01$ & - & - & \\
\hline $16: 0$ & $25,4 \pm 0,19$ & $25,4 \pm 0.04$ & $23,7 \pm 0,04$ & $23,0 \pm 0,07$ & $22,1 \pm 0,03$ & $22,6 \pm 0,02$ & $19,3 \pm 0,06$ & $19,2 \pm 0,07$ & $18,9 \pm 0,00$ & $20,5 \pm 0,01$ & $20,1 \pm 0,09$ & $18,8 \pm 0,30$ & $12,1 \pm 0,0$ & $12,0 \pm 0,03$ & $12,0 \pm 0.01$ \\
\hline $16: 1$ & $2,4 \pm 0,00$ & $2,3 \pm 0.00$ & $2,4 \pm 0,00$ & $1,9 \pm 0,00$ & $1.7 \pm 0,00$ & $1,8 \pm 0,00$ & $1,3 \pm 0,01$ & $1,3 \pm 0,00$ & $1,3 \pm 0,00$ & $1,3 \pm 0,03$ & $1,2 \pm 0,00$ & $1,2 \pm 0,03$ & - & - & - \\
\hline $18: 0$ & $13,3 \pm 0,05$ & $13,3 \pm 0.10$ & $12,7 \pm 0,02$ & $11,7 \pm 0,01$ & $11,8 \pm 0,02$ & $11,7 \pm 0,01$ & $9,5 \pm 0,30$ & $9,5 \pm 0,00$ & $8,9 \pm 0,00$ & $8,3 \pm 0,00$ & $9,1 \pm 0,06$ & $8,8 \pm 0,06$ & $4,1 \pm 0,02$ & $4,1 \pm 0,00$ & $4,1 \pm 0.00$ \\
\hline $18: 1 n-9$ & $41,4 \pm 0,01$ & $41,2 \pm 0,08$ & $42,9 \pm 0,01$ & $37,0 \pm 0,02$ & $37,6 \pm 0,04$ & $37,3 \pm 0.02$ & $32,8 \pm 0,07$ & $33,2 \pm 0,02$ & $32,7 \pm 0,00$ & $30,5 \pm 0,02$ & $31,1 \pm 0,09$ & $31,8 \pm 0,11$ & $22,1 \pm 0,03$ & $22,5 \pm 0,02$ & $22,5 \pm 0.01$ \\
\hline $18: 1 n-9 t$ & $2,7 \pm 0,01$ & $2,7 \pm 0,04$ & $2,5 \pm 0,00$ & $2,4 \pm 0,00$ & $2,5 \pm 0,02$ & $1,5 \pm 0,07$ & $2,1 \pm 0,09$ & $2,2 \pm 0,00$ & $2,2 \pm 0,00$ & $2,0 \pm 0,02$ & $2,14 \pm 0,00$ & $2,1 \pm 0,00$ & $1,5 \pm 0,05$ & $1,5 \pm 0,00$ & $1,5 \pm 0.00$ \\
\hline $18: 2 n-6$ & $13,4 \pm 0,00$ & $13,6 \pm 0.02$ & $14,4 \pm 0,02$ & $21,5 \pm 0,04$ & $22,0 \pm 0,02$ & $22,7 \pm 0,04$ & $31,1 \pm 0,00$ & $31,3 \pm 0,06$ & $32,7 \pm 0,00$ & $33,5 \pm 0,03$ & $32,9 \pm 0,70$ & $34,1 \pm 0,15$ & $55,6 \pm 0,02$ & $55,1 \pm 0,00$ & $55,1 \pm 0.00$ \\
\hline $18: 3 n-3$ & - & - & - & $1,3 \pm 0,00$ & $1.3 \pm 0,01$ & $1,2 \pm 0,01$ & $3,1 \pm 0,00$ & $2,3 \pm 0,01$ & $2,3 \pm 0,00$ & $2,4 \pm 0,02$ & $2,3 \pm 0,07$ & $2,4 \pm 0,12$ & $4,6 \pm 0,01$ & $4,8 \pm 0,01$ & $4,8 \pm 0.02$ \\
\hline $18: 2 / 18: 3$ & - & - & - & 16,5 & 16,9 & 18,9 & 10,0 & 13.4 & 14,2 & 13,9 & 14,3 & 14,2 & 12,1 & 11,5 & 11,5 \\
\hline $\mathrm{P} / \mathrm{S}$ & 0,3 & 0,3 & 0,4 & 0,6 & 0,6 & 0,7 & 1,1 & 1,1 & 1,2 & 1,2 & 1,1 & 1,5 & 1,6 & 1,5 & 1,5 \\
\hline II & 59 & 59 & 62 & 72 & 74 & 75 & 90 & 89 & 91 & 103 & 100 & 100 & 115 & 115 & 115 \\
\hline
\end{tabular}

Valores médios de duplicatas \pm Desvio padrão da média.

\author{
P/S - Poliinsaturados/Saturados \\ II - Índice de lodo
}




\subsubsection{Indice de iodo}

O índice de iodo é um parâmetro de qualidade na análise de gorduras, que mede o grau de insaturação sem contudo especificar os ácidos graxos. $O$ índice de iodo das misturas foi alterado em função da proporção de óleo de soja, e este parâmetro não foi alterado pela interesterificação.

\subsubsection{Ponto de amolecimento}

Os resultados obtidos para o ponto de amolecimento de todas as amostras podem ser observados na Figura 19. A banha apresentou ponto de amolecimento de $31,8^{\circ} \mathrm{C}$, que se encontra dentro da faixa descrita pelo CODEX ALIMENTARIUS (1999), que descreve ampla faixa de temperatura para o ponto de amolecimento da banha (28 a $40^{\circ} \mathrm{C}$ ). Após a interesterificação, o ponto de amolecimento da banha foi reduzido a 29,1 ํㅡ e 28,8 ํㅡ quando catalisada pelas lipases AY30 e M10, respectivamente. A adição de óleo de soja promoveu redução no ponto de amolecimento, muito provavelmente causada pela incorporação dos ácidos graxos poliinsaturados provenientes do óleo de soja.

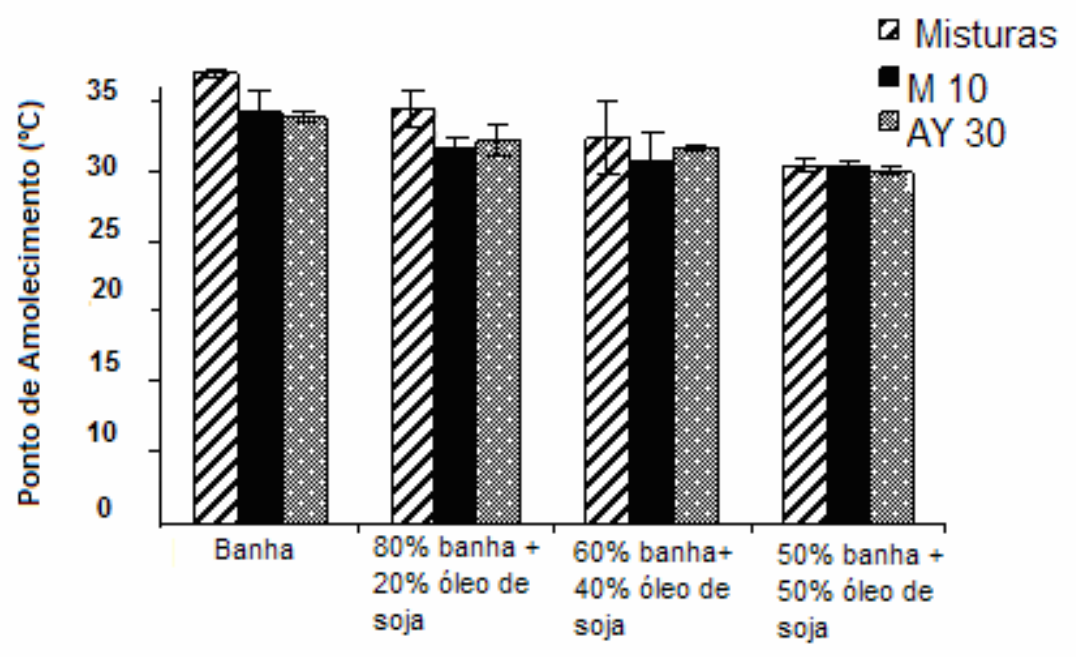

Figura 19. Ponto de amolecimentos da banha e suas misturas binárias, antes e após a interesterificação. 
SILVA e colaboradores (2007) relataram o ponto de amolecimento do leite humano de $31,5{ }^{\circ} \mathrm{C}$. Neste trabalho, todas as misturas apresentaram ponto de amolecimento próximo a este valor, antes e após a interesterificação, com ambas lipases utilizadas. As misturas interesterificadas apresentaram valores de ponto de amolecimento menores quando comparados às misturas antes da interesterificação.

Estes resultados estão próximos aos encontrados por outros pesquisadores, que interesterificaram sebo bovino com óleo de canola utilizando como catalisador a lipase específica sn-1,3 (FORSSEL et al., 1992; KOWALSKI et al., 2004). decréscimo no ponto de amolecimento da banha e das misturas interesterificadas foi causado muito provavelmente pela mudança da estrutura dos triacilgliceróis após a interesterificação. Devido às trocas dos ácidos graxos entre os triacilgliceróis, novos triacilgliceróis são formados e novas inter-relações podem aparecer. O decréscimo observado no ponto de amolecimento foi maior após a interesterificação com a lipase M10 lipase, comparado à lipase AY30.

$\mathrm{Na}$ interesterificação enzimática, em reações de tempo prolongado, pequenas trocas podem ocorrer nos ácidos graxos esterificados na posição sn-2 resultando na migração acil, como descrito pelos pesquisadores XU et al. (1998).

\subsubsection{Consistência}

A textura de "spreads" (margarinas ou cremes vegetais) é fator crítico na determinação da funcionalidade do produto e aceitabilidade pelo consumidor (WRIGHT et al., 2001).

As Figuras 20, 21, 22 e 23 apresentam os resultados obtidos para consistência da banha e suas misturas com o óleo soja antes e após a reação de interesterificação enzimática.

A consistência decresce em função do aumento de temperature e isto se deve à fusão gradual dos cristais, enfraquecendo a rede cristalina (ROUSSEAU, HILL, \& MARANGONI, 1996), que é responsável pela plasticidade de gorduras. As consistências das misturas não interesterificadas foram sempre superiores quando comparadas às misturas submetidas à reação de interesterificação em todas as temperaturas estudadas. 


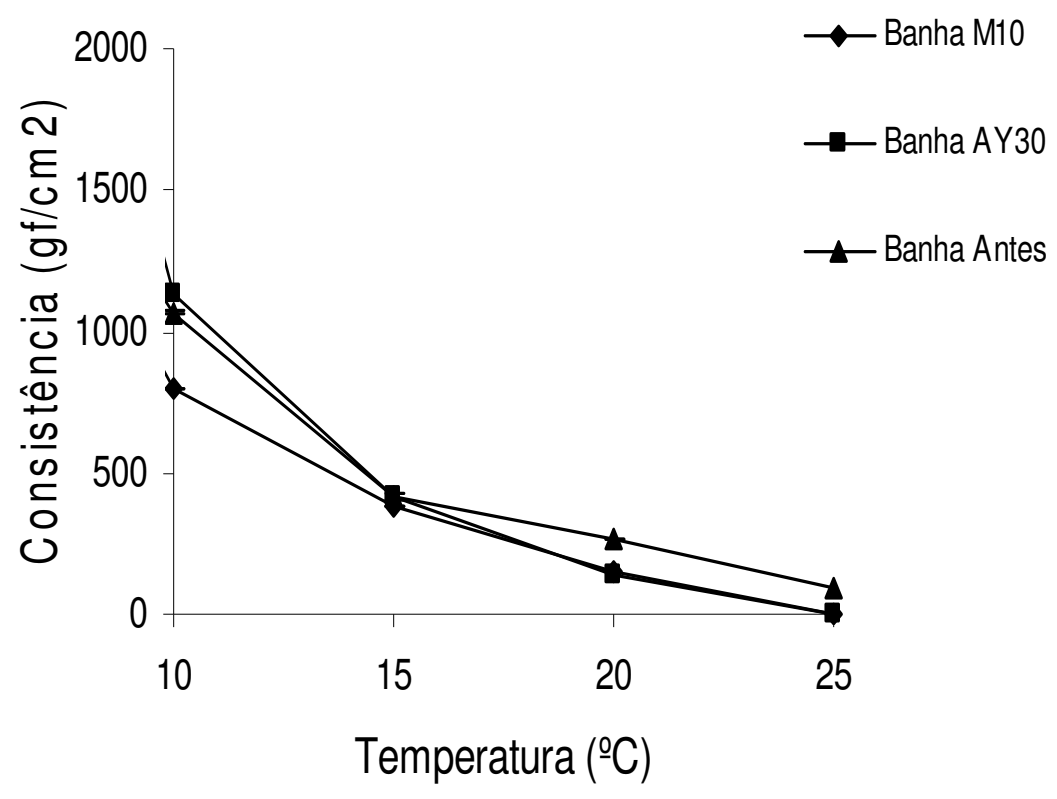

Figura 20. Consistência da banha antes e após a interesterificação.

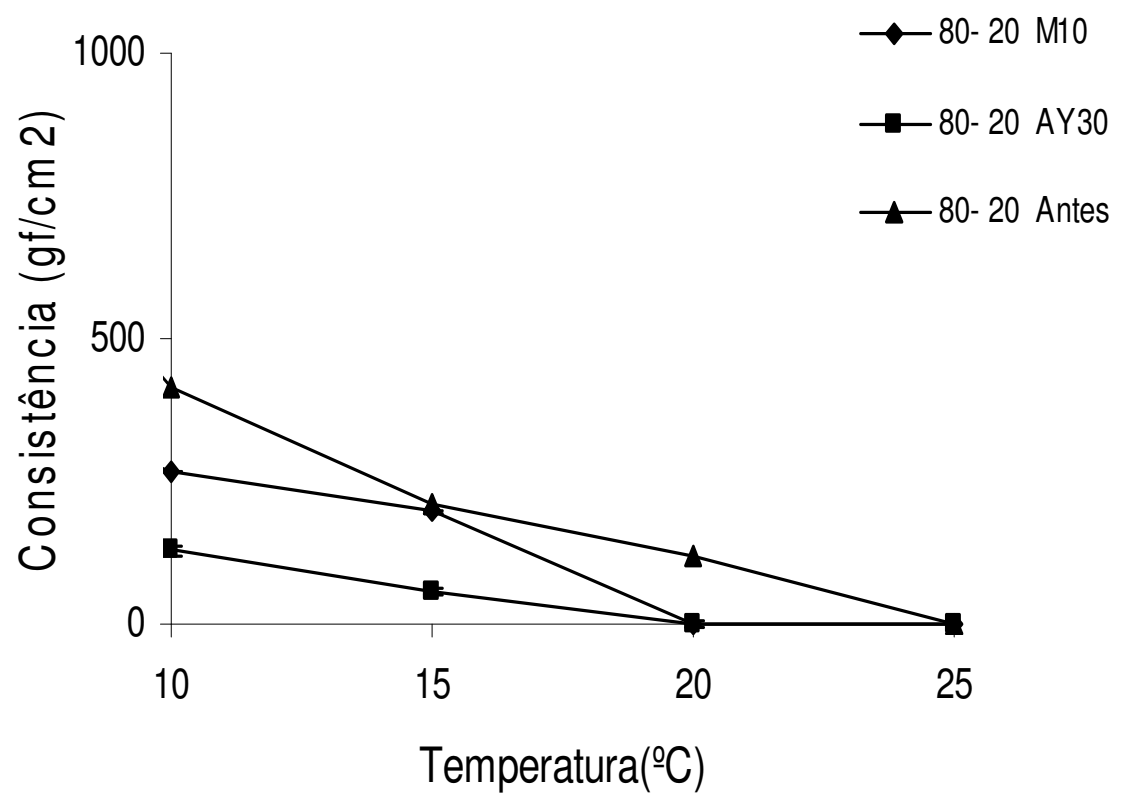

Figura 21. Consistência da mistura contendo $80 \%$ banha e $20 \%$ óleo de soja antes e após a interesterificação. 


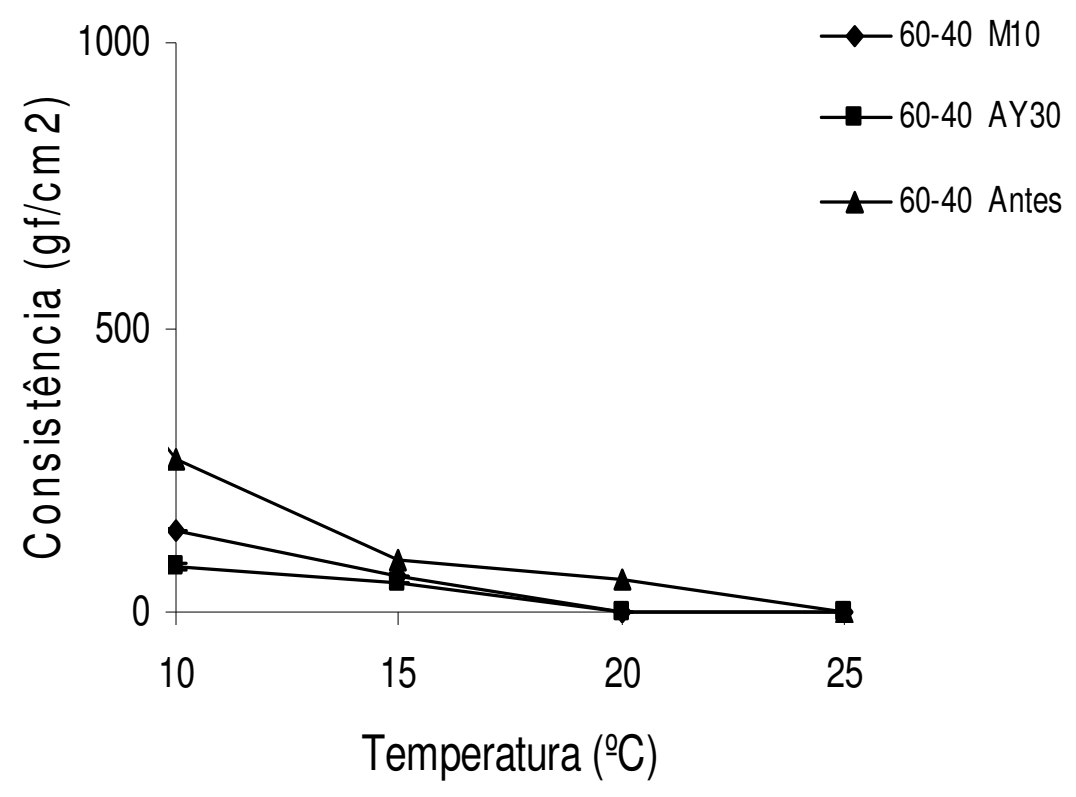

Figura 22. Consistência da mistura contendo $60 \%$ banha e $40 \%$ óleo de soja antes e após a interesterificação.

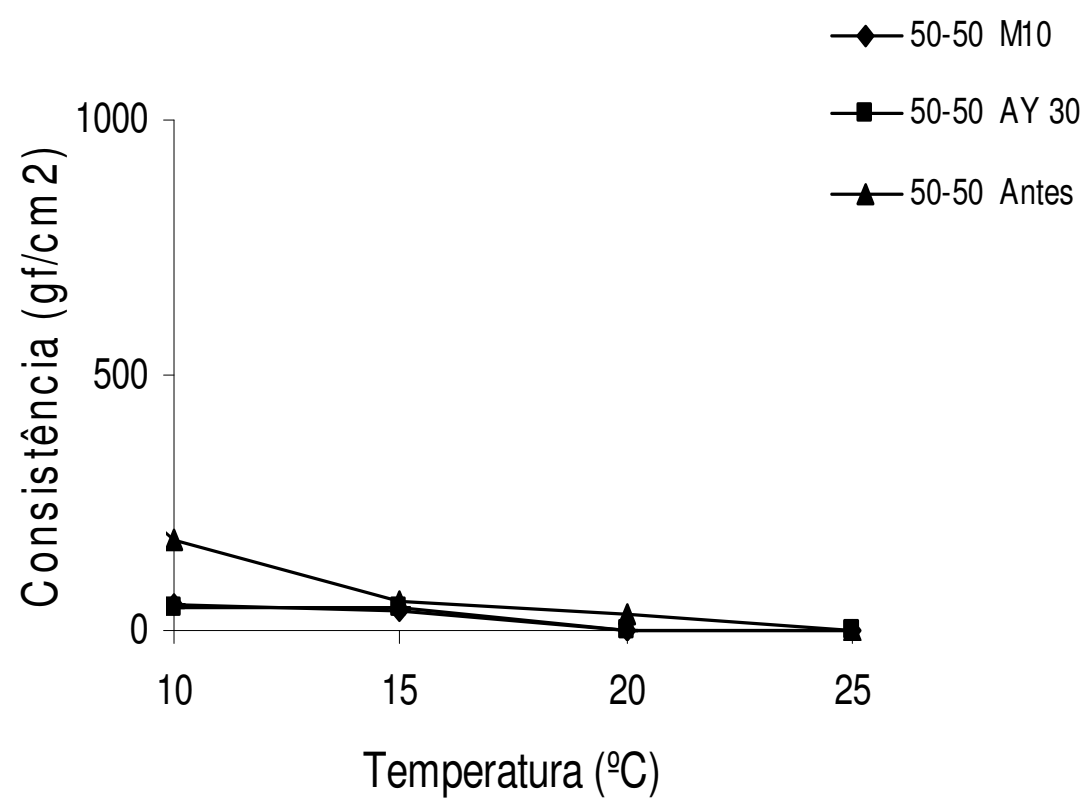

Figura 23. Consistência da mistura contendo $50 \%$ banha e $50 \%$ óleo de soja antes e após a interesterificação. 
Nenhuma das amostras analisadas apresentou consistência a $30 \stackrel{\circ}{\circ}$. O valor zero para consistência representa fisicamente um produto com muito baixa consistência, na qual o equipamento analítico não é capaz de detectar. Estes produtos se apresentam geralmente na forma de fluido muito viscoso.

A tendência de cristalização (morfologia e polimorfismo) da banha interesterificada é substancialmente diferente da banha em sua forma natural. Estas diferenças na tendência de cristalização e no comportamento de agregação dos cristais causam alterações na estrutura da rede cristalina da banha e consequentemente alterações em propriedades reológicas, como a consistência (MARANGONI \& ROSSEAU, 1998).

\subsubsection{Conteúdo de Gordura Sólida}

A alteração na composição dos triacilgliceróis da banha e das suas misturas com o óleo de soja após a interesterificação refletiu diretamente no conteúdo de gordura sólida analisado nas temperatures de 10-40 ำ. Reduções significativas no conteúdo de gordura sólida ocorreram após a interesterificação enzimática. A curva de sólidos da banha e das misturas com o óleo de soja pode ser observada nas Figuras 24, 25, 26 e 27. 


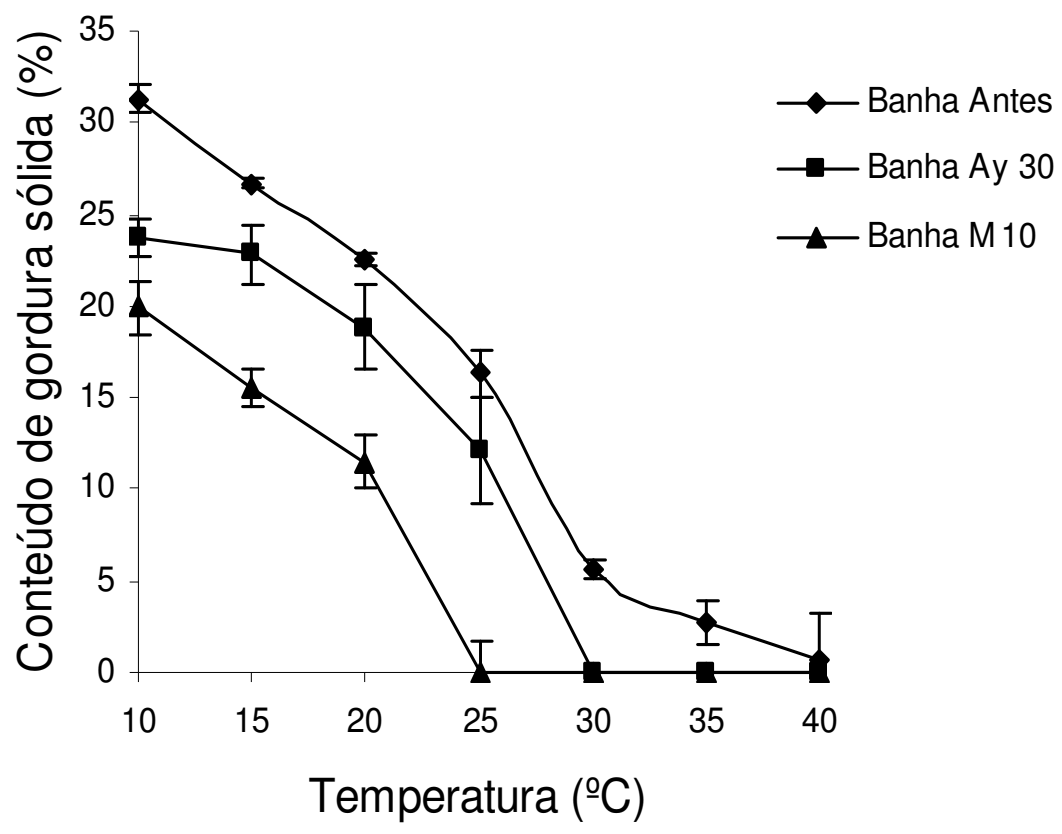

Figura 24. Conteúdo de gordura sólida da banha antes e após a interesterificação.

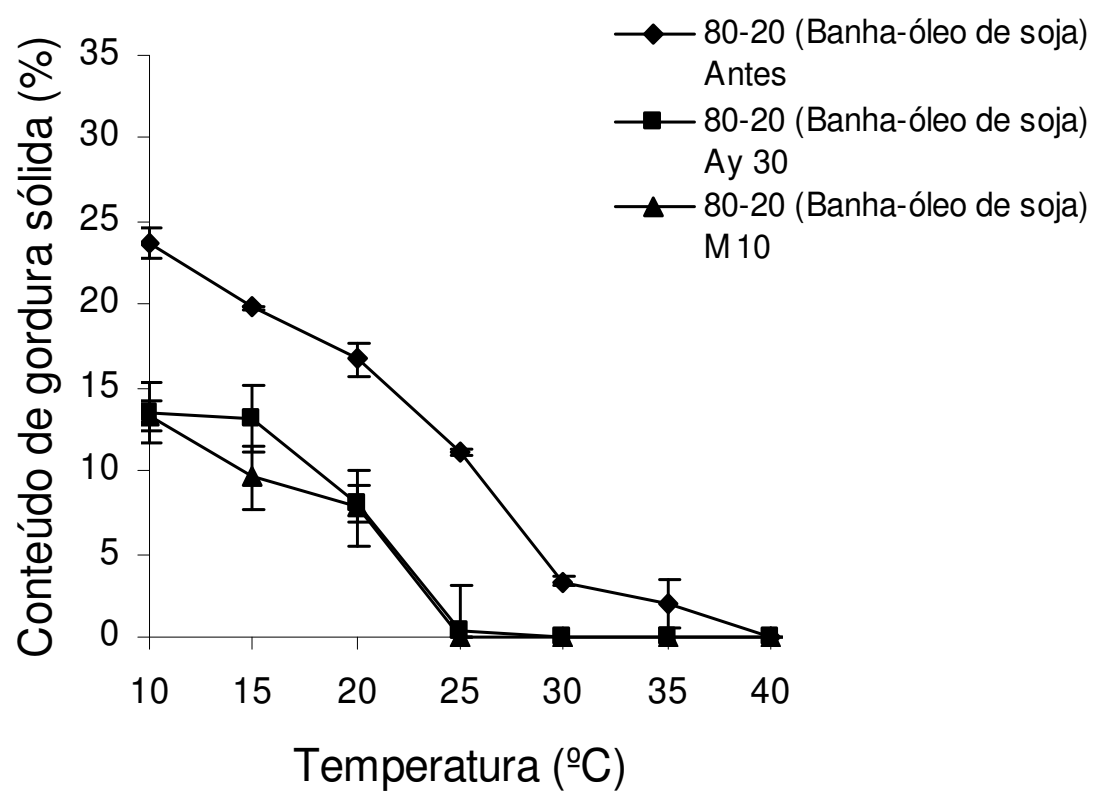

Figura 25. Conteúdo de gordura sólida da mistura contendo $80 \%$ banha e $20 \%$ óleo de soja antes e após a interesterificação. 


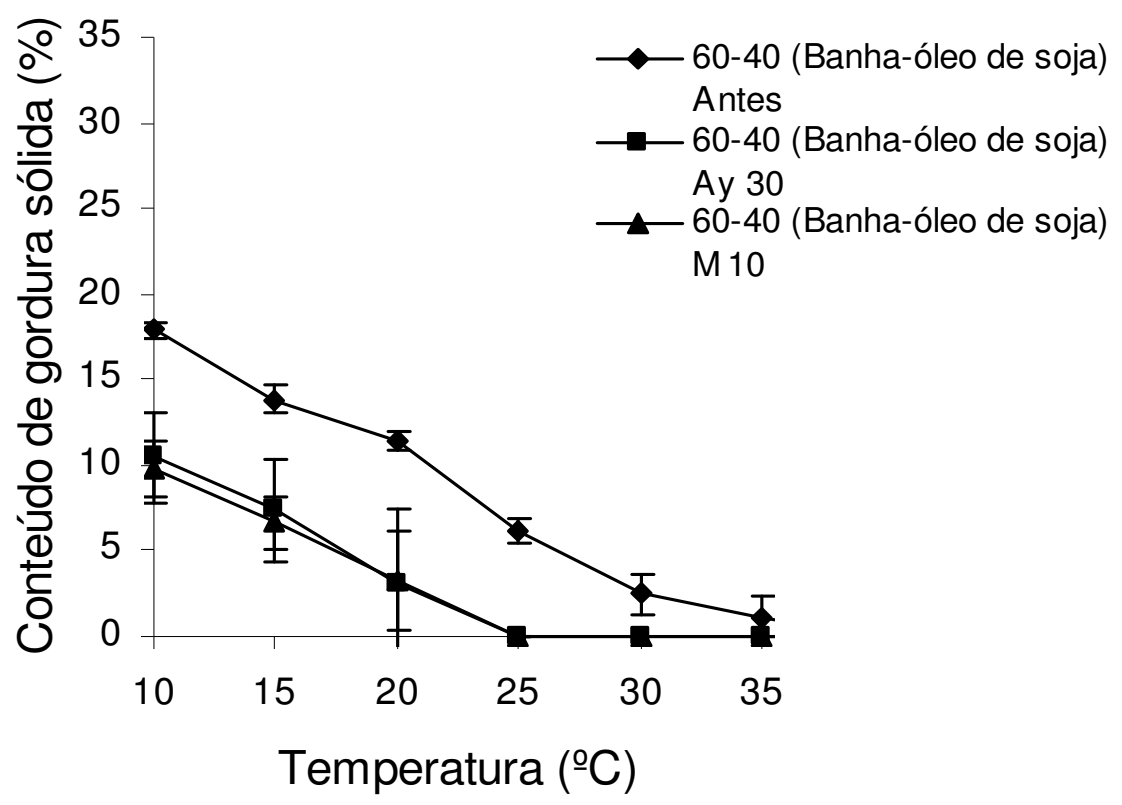

Figura 26. Conteúdo de gordura sólida da mistura contendo 60\% banha e $40 \%$ óleo de soja antes e após a interesterificação.

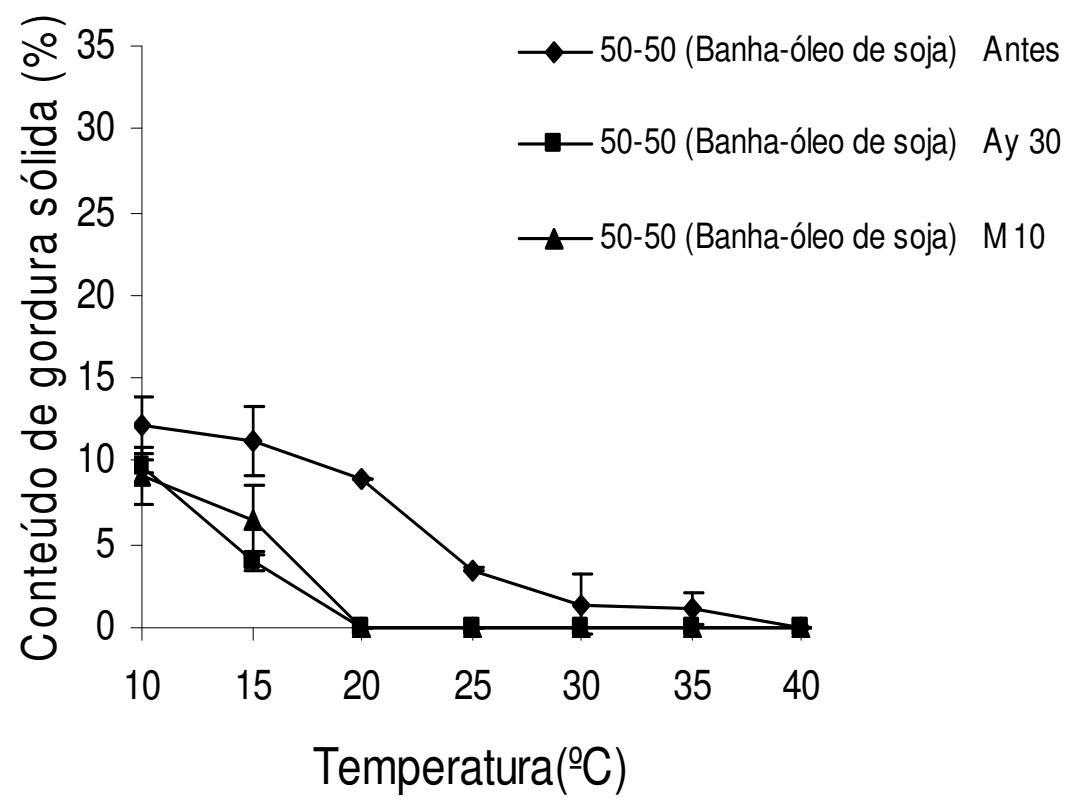

Figura 27. Conteúdo de gordura sólida da mistura contendo 50\% banha e $50 \%$ óleo de soja antes e após a interesterificação. 
O conteúdo de gordura sólida da banha foi substancialmente reduzido após a reação de interesterificação enzimática. A redução no conteúdo de gordura sólida da banha foi maior quando foi utilizada como catalisador a lipase M10 comparada à lipase AY30.

A banha não interesterificada apresentou conteúdo de gordura sólida de $31,3 \%$ a $10{ }^{\circ} \mathrm{C}$, que foi reduzido a $23,8 \%$ e $19,9 \%$ após as reações de interesterificação catalisadas pelas enzimas AY30 e M10, respectivamente.

A adição de óleo de soja, por ser um líquido, provocou diminuição no conteúdo de gordura sólida. Quando a banha foi adicionada de 20,40 e $50 \%$ de óleo de soja, o conteúdo de gordura sólida a $10{ }^{\circ} \mathrm{C}$ foi reduzido a cerca $23,7,17,9$ e $12,5 \%$, respectivamente. Nas misturas binárias, a reação de interesterificação não promoveu diferenças significativas entre as lipases utilizadas (Figuras 24, 25, 26 e 27).

Em todas as misturas observa-se que o aumento da temperatura provocou diminuição no conteúdo de gordura sólida devido à fusão dos cristais. MARANGONI \& ROUSSEAU (1998) encontraram o mesmo comportamento para misturas entre banha e óleo de canola. Segundo a literatura (DEMAN et al., 1991; MARANGONI \& ROUSSEAU, 1998; DAVENEL et al., 1999) a banha apresenta conteúdo de gordura sólida em torno de $20 \%$ a $25 \stackrel{\circ}{\circ}$, valor este próximo ao obtido neste trabalho. A banha e as misturas com o óleo de soja foram afetadas pela interesterificação enzimática e pela diluição com o óleo de soja.

\subsubsection{Análise Estatística}

A análise estatística revelou que as propriedades de conteúdo de gordura sólida, ponto de amolecimento e consistência não foram dependentes do óleo de soja ( $p>0,05$ ), mas foram dependentes da banha e da interação entre as duas gorduras $(p<0,05)$. Os coeficientes da interação sempre foram negativos, demonstrando a ocorrência de que interação monotética entre a banha e o óleo de soja. As amostras interesterificadas demonstraram o mesmo comportamento. 


\subsection{CONCLUSÃO}

A adição de óleo de soja promoveu decréscimo generalizado nos valores das propriedades físicas de ponto de amolecimento, consistência e conteúdo de gordura sólida da banha. A banha e as misturas com o óleo de soja foram afetadas pela reação de interesterificação enzimática, com acentuadas reduções do ponto de amolecimento, consistência e conteúdo de gordura sólida. Essas reduções na banha foram maiores quando a reação de interesterificação foi catalisada pela enzima específica sn-1,3 M10. 


\subsection{REFERÊNCIAS BIBLIOGRÁFICAS}

AKIMMOTO, K.; YAMAGUCHI, T.; FUJIKAWA, S. (1999). Novel triglyceride and composition comprising the same. Europen Patent 0965578 A1.

AKOH, C.C. Structured lipids. In: AKOH C.C.; MIN, D.B. Food Lipids 2002 p 877-908. Marcel Dekker, New York.

AKOH, C.C.; MOUSSATA C.O. Lipase-catalysed modification of borage oil: incorporation of capric and eicosapentanoic acids to form a strutured lipid. Journal of the American Oil Chemists' Society. v.75, n.6, p.697-701, 1998

AOCS (1997a). Official method Ce 1-62: Fatty acid composition by gas chromatography. Official methods and recommended practices of the American Oil Chemists' Society.

AOCS (1997b). Official Method Cd 1-25: lodine value calculated by fatty acid composition. Ibid.

AOCS (1997c). Official method Cc 3-25: Softening point. Ibid.

AOCS (1999). Official method Cd 16b-93: Solid fat content. Ibid.

BALCÃO, V.M.; PAIVA, A.L.; MALCATA, F.X. Bioreactors with immobilized lipases: State-of-the-art. Enzyme and Microbial Technology, v.18, n.6, p.392-416, 1996.

BALCÃO, V.M.; MALCATA, F.X. Enzyme-mediated modification of milkfat. In: KUO, G.T.M. Lipid Biotechnology. p 479-492, Marcel Dekker, New York. 2002

BALCÃO, V.M.; MALCATA, F.X. Lipase-catalyzed modification of butterfat via acidolysis with oleic acid, Journal of Molecular Catalysis B: Enzymatic, v.3, n.1-4, p.161-169, 1997

BALCÃO, V.M.; MALCATA, F.X. Lipase catalyzed modification of milkfat. Biotechnology Advances. v.16, n.2, p.309-341, 1998a.

BALCÃO, V.M.; MALCATA, F.X. Interesterification and acidolysis of butterfat with oleic acid by Mucor javanicus lipase: changes in the pool of fatty acid residues. Enzyme and Microbial Technology, v.22, n.6, p.511-519, 1998b.

BALCÃO, V.M.; KEMPPINEN, A.; MALCATA, F.X.; KALO, P. Lipase-catalyzed acidolysis of butterfat with oleic acid: characterization of process and product. Enzyme and Microbial Technology, v.23, n.2, p.118-128,1998a.

BALCÃO, V.M.; KEMPPINEN, A.; MALCATA, F.X.; KALO, P. Modification of butterfat by selective hydrolysis and interesterification by lipase: process and product characterization. Journal of the American Oil Chemists' Society. v.75, n.10, p.1347-1358, 1998b. 
BALCÃO, V.M.; MALCATA, F.X. On the performance of a hollow-fiber bioreactor for acidolysis catalyzed by immobilized lipase. Biotechnology and Bioengineering, v.60, n.1, p.114-123, 1998c.

CODEX ALIMENTARIUS. Codex. Standard for Named Animal Fats - CODEX - STAN 211 [internet document] URL http://www.codexalimentarius.net/search/advancedsearch.do._Accessed 02/08/2007, 1999.

CHRISTENSEN, T.C.; HOLMER, G. Lipase catalysed acyl-exchage reactions of butter oil. Synthesis of a human milk fat substitute for infant formulas. Milchwissenschaft - Milk Science International, v.48, n.3, p.543-547, 1993.

DAVENEL, A.; RIAUBLANC, A.; MARCHAL, P.; GANDEMER, G. Quality of pig adipose tissue: relationship between solid fat content and lipid composition. Meat Science, v.51, n.1, p.73-79, 1999.

DEMAN, L.; SHEN, C.F.; DEMAN, J.M. Composition physical and textural characteristics of soft (tub) margarines. Journal of the American Oil Chemists' Society. v.68, n.1, p.70-73, 1991.

FORSSELL, P.; KERVINEN, R.; LAPPI, M.; LINKO, P.; SUORTTI, D.; POUTANEN, $K$. Effect of enzymatic interesterification on the melting point of tallow-rapeseed oil (LEAR) mixture. Journal of the American Oil Chemists' Society. v.69, n.1, p.126129, 1992.

GLÄSER, K.R.; WENK, C.; SCHEEDER, R.L. Evaluation of pork backfat firmmes and lard consistency using several different physicochemical methods. Journal of Science Food and Agriculture, v.84, n.8, p.853-862, 2004.

HAIGHTON, A.J. The measurement of the hardness of margarine and fats with cone penetrometers. Journal of the American Oil Chemists' Society. v.36, n.8, p.345348, 1959.

HARTMAN, L.; LAGO, R.C.A. Rapid preparation of fatty acid methyl esters from lipids. Laboratory Practices, v.22, p.475-494, 1973.

INNIS, S.M.; DYER, R.A.; QUINLAN, P.; DIERSEN-SCHADE, D. Palmitic acid is absorbed as sn-2 monopalmitin from milk and formula with rearranged triacylglycerols and results in increased plasma triglyceride $s n-2$ and cholesteryl ester palmitate in piglets. The Journal of Nutrition. v.125, n.1, p.73-81,1995

KOWALSKI, B.; TARNOWSKA, K.; GRUCZYNSKA, E.; BEKAS, W. Chemical and enzymatic interesterification of a beef tallow and rapeseed oil equal-weight blend. European Journal of Lipid Science and Technology. v.106, n.10, p.655-664, 2004.

LEE, K.T.; AKOH, C.C. Characterization of enzymatically syntetized structured lipids containing eicosapentaenoic, docosahexanoic and caprylic acids. Journal of the American Oil Chemists' Society. v.75, n.4, p.495-499, 1998. 
LIST, G.R.; MOUNTS, T.L.; ORTHOEFER, F.; NEFF, W.E. Margarine and shortening oils by interesterification of liquid and trisaturated triglycerides. Journal of the American Oil Chemists' Society. v.72, n.3, p.379-382, 1995.

LOHMAN, M.H.; HARTEL, R.W. Effect of milk fat fractions on fat bloom in dark chocolate. Journal of the American Oil Chemists' Society. v.71, n.2, p.267-275, 1994.

MARANGONI, A.G.; ROUSSEAU, D. Chemical and enzymatic modification of butterfat and butterfat-canola oil blends. Food Research International, v.31, p.595599, 1998.

MUKHERJEE, K.D.; KIEWIT, I. Structured triacylglycerols resembling human milk fat by transesterification catalyzed by papaya (Carica papaya) latex. Biotechnology Letters, v.20, p.613-616, 1998.

NIELSEN, N.S.; YANG, T.; XU, X.; JACOBSEN, C. Production and oxidative stability of a human milk fat substitute produced from lard by enzyme technology in a pilot packed-bed reactor. Food Chemistry, v.94, p.53-60, 2006.

NOOR LIDA, H.M.D.; ALI, A.R. Physical-chemical characteristics of palm-based oil blends for the production of reduced fat spreads Journal of the American Oil Chemists' Society, v.75, p.1625-1631, 1998.

O'BRIEN, R.D. Fats and oils - Formulating and processing for applications. Pp. 7-10, 33-36, 98-108, Basel: Technomic. 1998

OSBORN, H.T.; AKOH, C.C. Structured lipids - novel fats with medical, nutraceutical, and food applications. Comprehensive Reviews In: Food Science and Food Safety, v.3, p.93-103. 2002.

PAEZ, B.C.; MEDINA, A.R.; RUBIO, F.C.; MORENO, P.G.; GRIMA, E.M. Production of structured triglycerides rich in $n-3$ polyunsaturated fatty acids by the acidolysis of cod liver oil and caprylic acid in a packed-bed reactor: equilibrium kinetics. Chemical Engineering Science, v.57, p.1237-1249, 2002.

REGADO, M.A.; CRISTÓVÃO, B.M.; AIRES-BARROS R.; FERREIRA, J.P.; MOUTINHO, C.G.; BALCÃO, V.M.; MALCATA, F.X. Flavour development via lipolysis of milkfats: changes in free fatty acid pool. International Journal of Food Science and Technology, v.42, p.961-968, 2007.

REGADO, M.A.; CRISTÓVÃO, B.M.; TAVARIA, F.K.; FERREIRA, J.P.; MOUTINHO, C.G.; BALCÃO, V.M.; MALCATA, F.X. Changes in the pool of free fatty acids in ovine, bovine and caprine milk fats, effected by viable cells and cell-free extracts of Lactococcus lactis and Debaryomyces vanrijiae. Food Chemistry. v.103, p.11121118, 2007.

RODRIGUEZ, A.; CASTRO, E.; SALINAS, M.C.; LOPEZ, R.; MIRANDA, M. Interesterification of tallow and sunflower oil. Journal of the American Oil Chemists' Society. v.78, p.431-436, 2001. 
ROUSSEAU, D.; HILL, A.R.; MARANGONI, A.G. Restructuring butterfat through blending and chemical interesterification. 3. Rheology. Ibid, v.73, p.983-989 1996.

SAHIN, N.; AKOH, C.C.; KARAALI, A. Lipase-catalyzed acidolysis of tripalmitin with hazelnut oil fatty acids and stearic acid to produce human milk fat substitutes. Journal of Agriculture and Food Chemistry, v.53, p.5779-5783, 2005.

SCHIMID, U.; BORNSCHEUER, U.T.; SOUMANOU, M.M.; MACNEILL, G.P.; SCHMID, R.D. Optimization of the reaction conditions in the lipase-catalyzed synthesis of structured triglycerides. Journal of the American Oil Chemists' Society. v.75, p.1527-1531, 1998

SENANAYAKE, S.P.J.N.; SHAHIDI, F. Structured lipids via lipase catalyzed incorporation of eicosapenoic acid into borage (Borago officinalis L.) and evening primrose (Oenothera biennis L.) oils. Journal of Agriculture and Food Chemistry, v.50, p.477-483, 2002.

SILVA, R.C.; ESCOBEDO, J.P.; QUINTAL, V.S.; IBIDI, S.M.; ALBUQUERQUE, E.M.; GIOIELLI, L.A. Composição centesimal do leite humano e caracterização das propriedades físicoquímicas de sua gordura. Química Nova v.30, n.7 p.1535-1538, 2007.

TIMMS, R.E. Phase behaviour of fats and their mixtures. Progress in Lipid Research, v.23, p.1-38, 1984.

WILLIS, W.M.; MARANGONI, A.G. Assessment of lipase and chemically catalysed lipid modification strategies for the production of structured lipids. Journal of the American Oil Chemists' Society. v.76, p.443-450, 1999.

WILLIS, W.M.; LENCKI, R.W.; MARANGONI, A.G. Lipid modification strategies in the production of nutritionally functional fats and oils. Critical Reviews In Food Science and Nutrition, v.38, p.639-674, 1998.

WRIGHT, A.J.; SCANLON, M.G.; HARTEL, R.W.; MARANGONI, A.G. Rheological properties of milkfat and butter. Journal of Food Science, v.66, p.1056-1071, 2001.

XU, X.B.; SKANDS, A.R.H.; ADLER-NISSEN, J; HØY, C.E. Production of specificstructured lipids by enzymatic interesterification: optimization of the reaction by response surface design. Fett / Lipid, v.100, p.463-471. 1998.

$\mathrm{XU}$, X.B. Production of specific-structured triacylglycerols by lipase-catalyzed reactions: A review. European Journal of Lipid Science and Technology, v.102, p.287-303, 2000.

XU, X.; ZHOU, D.; MU, H.; ADLER-NISSEN, J.; ERIK HØY, C. A packed-bed enzyme mini-reactor for the production of structured lipids using nonimmobilized lipases. Journal of the American Oil Chemists' Society. v.79, p.205-206, 2002. 
YANG, T.K.; XU, X.B.; HE, C.; LI, L. Lipase catalyzed modification of lard to produce human milk fat substitutes. Food Chemistry, v.80, p.472-481, 2003.

YANG, T.K.; FRUEKILDE, M.B. Applications of immobilized Thermomyces lanuginosa lipase in interesterification. Journal of the American Oil Chemists' Society. v.80, p.881-887, 2003. 



\section{Interesterificação enzimática de banha e}

\section{óleo de soja para a produção de sucedâneo da}

\section{gordura do leite humano}

SILVA, R.C.; COTTING, L.N.; POLTRONIERI, T.P.; BALCÃO, V.M.; ALMEIDA, D.B.; GONCALVES, L.A.G.; GRIMALDI, R.; GIOIELLI, L.A. Enzymatic interesterification of lard with soybean oil for production of human milk fat analog 



\section{Resumo}

O objetivo deste trabalho foi avaliar as propriedades fisico-químicas de lipídios estruturados sucedâneos da gordura do leite humano. Estes lipídios foram produzidos a partir de banha e de suas misturas binárias com o óleo de soja e catalisados pela lipase comercial Lipozyme TL IM proveniente do microorganismo Thermomyces lanuginosa. A interesterificação enzimática produziu novos triacilgliceróis que consequentemente mudaram as propriedades físico-químicas dos lipídios estruturados. O conteúdo de gordura sólida, a consistência e o ponto de amolecimento da banha pura aumentaram após a interesterificação, que se deve ao aumento de triacilgliceróis do grupo SSS+SSI. A adição de óleo de soja à banha promoveu decréscimo no conteúdo de gordura sólida, consistência e ponto de amolecimento, devido à incorporação de ácidos graxos poliinsaturados presentes no óleo de soja, promovendo aumento de triacilgliceróis do grupo III e redução nos triacilgliceróis dos grupos SSS+SSI. As misturas de banha e óleo de soja interesterificadas apresentaram menores valores para as propriedades físicas quando comparadas às misturas antes da interesterificação enzimática. A interesterificação da banha com o óleo de soja aumentou os triacilgliceróis do grupo III e SSS e reduziu a quantidade de triacilgliceróis IIS. 


\subsection{INTRODUÇÃO}

Lipídios estruturados são definidos como uma nova geração de gorduras que podem ser consideradas como nutracêuticas: alimentos ou parte de alimentos que fornecem benefícios saudáveis ou até mesmo médicos, incluindo potenciais para a redução no risco de doenças $(\mathrm{AKOH}, 2002)$. Os lipídios estruturados são produzidos por modificação química ou enzimática dos triacilgliceróis (TAGs) (WILLIS \& MARANGONI, 1999). Nos últimos anos tem se dado preferência à modificação enzimática (FORMUSO \& AKOH, 2002; XU, FORMUSO \& AKOH, 2000; HAMAN \& SHAHIDI, 2005).

A utilização de lipases na modificação de óleos e gorduras tem muitos benefícios comparando ao processo catalisado por via química. Muitos estudos confirmam a eficácia das lipases em condições controladas (umidade, $\mathrm{pH}$ e temperatura). A reação catalisada por via enzimática tem custos reduzidos, diminuição no consumo de energia e apelo ambiental, com diminuição na produção de resíduos. Além disso, a grande variedade de fontes produtoras de lipases demonstra o enorme potencial desta alternativa de modificação de lipídios (YAMANE, 1987). Contudo, a mais importante propriedade das lipases na modificação de lipídios é a sua especificidade, que demonstra ser ferramenta versátil para a produção de triacilgliceróis com diferentes aplicações (MARANGONI \& ROSSEAU, 1995; WILLIS \& MARANGONI, 1998; GHAZALI, HAMIDAD \& CHE MAN, 1995).

As aplicações típicas dos lipídios estruturados são inúmeras, como a produção de margarinas, substitutos da manteiga de cacau, substitutos da gordura do leite humano, óleos de peixes modificados e "shortenings" para a indústria de alimentos entre outros (HAMAN \& SHAHIDI, 2005; NIELSEN et al., 2006; JENSEN, 2001).

O leite humano contém de $3-5 \%$ de lipídios totais, sendo que mais de $90 \%$ da gordura do leite é composta por triacilgliceróis, em que os ácidos graxos representam $88 \%$ dos lipídios totais (CHANG, ABRAHAN \& JOHN, 1990). Os triacilgliceróis são a principal fonte de energia do leite humano e de fórmulas infantis, fornecendo $50 \%$ da energia total da dieta (KENNEDY et al., 1999). 
A gordura do leite humano é composta principalmente por ácidos graxos de cadeia longa. O principal ácido graxo saturado da gordura do leite humano é o palmítico (16:0), que representa certa de $25 \%$ dos ácidos graxos. A gordura do leite humano contém cerca de $70 \%$ do ácido palmítico esterificado na posição sn-2 dos triacilgliceróis. O ácido esteárico ( 5-7\%), o ácido oléico ( 30-35\%), e o ácido linoléico $(\sim 7-14 \%)$ são geralmente esterificados nas posições $s n-1,3$ dos triacilgliceróis (NIELSEN et al., 2006). A estrutura do triacilglicerol do leite humano é unica, e a única gordura que tem esta estrutura similar é a banha (CHANG, ABRAHAN \& JOHN, 1990). O ácido pamítico esterificado na posição sn-2 não é hidrolisado pela lipase pancreática e é eficientemente absorvido na forma de 2monopalmitoilglicerol (THOMSON et al., 1989; FILLER et al., 1969). O ácido palmítico quando esterificado nas posições $s n-1,3$ é hidrolisado pela lipase pancreática, que produz ácido palmítico livre e forma sabões de cálcio no intestino, resultando em baixa absorção de cálcio e gordura (LIEN, 1994; LIEN et al., 1997; LUCAS et al., 1997). Devido a essa formação de sabões de cálcio, fezes endurecidas, constipação e alguns casos de obstrução intestinal podem ocorrer. Assim, a presença do ácido palmítico na posição sn-2 da gordura do leite humano aumenta a absorção de 16:0 nos recém-nascidos e reduz a perda de cálcio pelas fezes (CHAPPEL et al., 1986). Sendo assim, a estrutura dos triacilgliceróis com o ácido graxo esterificado na posição sn-2 tem importante função no desenvolvimento de bebês.

Recentemente, muitos estudos foram conduzidos na tentativa de produzir lipídios estruturados com configuração semelhante à gordura do leite humano para se utilizar em fórmulas infantis (MADUKO et al., 2007a,b; SRIVASTAVA et al., 2006; SAHIN, et al., 2005; MUKERJEE \& KIEWITT, 1998; THOMSON et al., 1989).

O objetivo deste trabalho foi produzir lipídios estruturados sucedâneos da gordura do leite humano a partir da interesterificação enzimática de misturas entre banha e óleo de soja catalisadas pela lipase comercial Lipozyme TL IM específica sn-1,3 proveniente do microorganismo Thermomyces lanuginosa, e também caracterizar os lipídos produzidos quanto às suas propriedades físico-químicas. 


\subsection{MATERIAL E MÉTODOS}

\subsubsection{Material}

A banha e o óleo de soja foram obtidos no comércio local (São Paulo). A lipase comercial proveniente do microorganismo Thermomices lanuginosa (Lipozyme TL IM) foi gentilmente doada pela empresa Novozymes (Araucária, Brasil). Todos os demais solventes e reagentes utilizados foram de grau analítico.

\subsubsection{Métodos}

\subsubsection{Misturas}

Três misturas binárias de banha e óleo de soja foram preparadas nas seguintes proporções: 80:20, 60:40 e 50:50 (p/p). As misturas foram preparadas após a completa fusão das gorduras a $70-80{ }^{\circ} \mathrm{C}$ por 30 min sob agitação constante, e armazenadas sob refrigeração a $4{ }^{\circ} \mathrm{C}$.

\subsubsection{Reação de interesterificação}

Foram interesterificados $250 \mathrm{~g}$ de amostra, previamente seca em balão de vidro, sob pressão reduzida, acoplado a um rotaevaporador em banho de água a aproximadamente $95^{\circ} \mathrm{C}$. A essa porção foram misturados $5 \%(\mathrm{~m} / \mathrm{m})$ da lipase. A reação de interesterificação foi realizada sob agitação constante (750 rpm), sob pressão reduzida, a $65-70^{\circ} \mathrm{C}$ em balão de três bocas imerso em banho de água a $75^{\circ} \mathrm{C}$, por 6 horas. Ao final de reação a mistura foi filtrada utilizando papel de filtro e armazenada a $-25^{\circ} \mathrm{C}$.

\subsubsection{Composição em ácidos graxos}

A análise da composição em ácidos graxos foi realizada após a conversão dos triacilgliceróis em esteres metílicos (FAME), de acordo com a metodologia proposta por HARTMAN \& LAGO (1973).

A análise da composição em ácidos graxos foi realizada em cromatógrafo a gás Varian GC, modelo 3400CX, equipado com detector de ionização de chama e "Workstation Star Chromatography". Foi utilizada coluna capilar de sílica fundida CP WAX 52 CB (Chrompack Minnesota MN, USA), com 30 metros de comprimento $x$ 
0,25 $\mathrm{mm}$ de diâmetro interno e contendo $0,25 \mu \mathrm{m}$ de polietilenoglicol dentro da coluna. As condições foram: injeção split, razão de 50:1; temperatura da coluna: 150 ${ }^{\circ} \mathrm{C}$ por $5 \mathrm{~min}$, programada até $215^{\circ} \mathrm{C}$ numa razão de $3 \stackrel{\circ}{\circ} / \mathrm{min}$; gás de arraste: hélio, numa vazão de $1,5 \mathrm{~mL} / \mathrm{min}$; gás make up: hélio a $30 \mathrm{~mL} / \mathrm{min}$; temperatura do injetor $250^{\circ} \mathrm{C}$; temperatura do detector $280^{\circ} \mathrm{C}$. A composição qualitativa foi determinada por comparação dos tempos de retenção dos picos com os respectivos padrões de ácidos graxos. A composição quantitativa foi realizada por normalização de área, sendo expressa como porcentagem em massa, de acordo com o método oficial AOCS Ce 1-62 (AOCS, 1997a). Todas as amostras foram analisadas em duplicata e os valores apresentados correspondem às médias destes valores.

\subsubsection{Ponto de amolecimento}

O ponto de amolecimento, utilizando tubo capilar aberto, foi determinado segundo o método Cc 3-25. (AOCS, 1997c). Todas as amostras foram analisadas em triplicata e os valores apresentados correspondem às médias destes valores.

\subsubsection{Consistência}

A análise de consistência foi efetuada através de teste de penetração com cone acrílico de ângulo $45^{\circ}$, em analisador de textura TA-XT2 da Stable Micro System, controlado por microcomputador (DÍAZ GAMBOA \& GIOIELLI, 2003a, 2003b).

Os testes foram conduzidos nas seguintes condições:

- Determinação da força em compressão

- Distância: 10,0 mm

- Velocidade: $2,0 \mathrm{~mm} / \mathrm{s}$

- Tempo: $5 s$

- Triplicata

Para realizar a conversão dos dados de penetração em um parâmetro independente do peso e do tipo de cone, foi utilizada a equação proposta por HAIGHTON (1959), para o cálculo do "yield value":

$$
\mathrm{C}=\frac{\mathrm{K} \times \mathrm{W}}{\mathrm{p}^{1.6}}
$$

Onde: 
$\mathrm{C}=$ "yield value", em $\mathrm{gf} / \mathrm{cm}^{2}$

$\mathrm{K}=$ fator que depende do ângulo do cone (para ângulo de 45ํㅡ, $\mathrm{K}$ é igual a 4.700)

$\mathrm{W}$ = peso total do sistema, em $\mathrm{g}$ (para penetrômetro de cone)

$\mathrm{p}=$ profundidade de penetração

Considerando as condições dos testes de compressão realizados com o analisador de textura, a equação assume a seguinte forma:

$\mathrm{C}=4700 . \mathrm{W} / 100^{1,6}$

Onde:

$\mathrm{C}=$ "yield value", em $\mathrm{gf} / \mathrm{cm}^{2}$

$\mathrm{W}=$ força em compressão, em gf, para tempo $=5 \mathrm{~s}$.

As amostras de gordura foram aquecidas à temperatura de $70-80 \stackrel{\circ}{\circ}$ em forno de microondas para a completa fusão dos cristais, sendo acondicionadas em béqueres de $50 \mathrm{~mL}$ (Pyrex, USA). O condicionamento foi efetuado por 24 horas em geladeira comum $\left(5-8^{\circ} \mathrm{C}\right)$ e em seguida por 24 horas em estufa com temperatura controlada (temperaturas de análise $\pm 0,5$ ). A medida foi realizada em triplicata, e os valores apresentados correspondem às médias dos três valores.

\subsubsection{Microscopia}

As amostras foram aquecidas a $70^{\circ} \mathrm{C}$ em estufa e mantidas nesta temperatura por 30 minutos com o intuito de destruir a memória cristalina. Uma gota da gordura fundida foi retirada com o auxílio de capilar, colocada na lâmina e coberta por lamínula também pré-aquecida na estufa. A lâmina pronta foi colocada sobre o controlador de temperatura do microscópio. Inicialmente a amostra foi submetida à temperatura de $60 \stackrel{\circ}{\circ}$ por 10 minutos, para garantir a fusão total dos cristais. Após esse período, as amostras foram condicionadas à temperatura de $30^{\circ} \mathrm{C}$ por 5 minutos, e finalmente foram condicionadas à temperatura de $15{ }^{\circ} \mathrm{C}$, quando foram capturadas as imagens a cada 15 minutos, em período de 1 hora de análise. A morfologia dos cristais foi estudada em condições isotérmicas (15 $\left.{ }^{\circ} \mathrm{C}\right)$ em microscópio de luz polarizada (Olympus System Microscope, model BX 50, Olympus America Inc.) conectado à câmera digital (Media Cybernetics). $O$ aumento utilizado foi de 40x. A temperatura da lâmina foi mantida por controlador de temperatura 
modelo TS-4 (Physitemp Instruments Inc.). As imagens capturadas foram analisadas usando o software Image Pro-Plus Versão 4.5.1 for Windows (Media Cybernetics).

\subsubsection{Conteúdo de gordura sólida}

O conteúdo de gordura sólida foi determinado por ressonância magnética nuclear, utilizando aparelho Maran Ultra Bench Top NMR de $20 \mathrm{MHz}$ (Oxford Instruments, England), de acordo com ométodo Cd 16b-93. (AOCS, 1999). Todas as amostras foram analisadas em duplicata e os valores apresentados correspondem às médias destes valores.

\subsubsection{Composição em triacilgliceróis}

A análise dos triacilgliceróis foi conduzida em cromatógrafo à gás (modelo CGC, Agilent 6850 Series CG System). Foi utilizada coluna capilar DB-17HT AGILENT de 15 metros de comprimento $X 0.25 \mathrm{~mm}$ de diâmetro contendo $0,15 \mu \mathrm{m}$ de $50 \%$ phenyl-methylpolysiloxane dentro da coluna. Gás de arraste: hélio, numa vazão de $1.0 \mathrm{~mL} / \mathrm{min}$; split na razão de 1:30. Temperatura do injetor: $360 \stackrel{\circ}{\circ}$;e temperatura do detector: $375 \stackrel{\circ}{ } \mathrm{C}$. Temperatura da coluna inicial: $250 \stackrel{\circ}{ } \mathrm{C}$, programada até $350^{\circ} \mathrm{C}$ numa razão de $5^{\circ} \mathrm{C} / \mathrm{min}$.

\subsubsection{Análise estatítica}

Os resultados referentes ao ponto de amolecimento, consistência e conteúdo de gordura sólida foram analisados estatisticamente por regressão múltipla (HARE, 1974) representada pela seguinte equação:

$$
Y=\beta_{1} X_{1}+\beta_{2} X_{2}+\beta_{12} X_{1} X_{2}
$$

onde: $Y=$ resposta;

$\beta=$ coeficientes gerados por regressão múltipla;

$X=$ proporção do componente.

O software Statistics 7.0 - StatSoft foi utilizado para gerar os coeficientes do modelo, apresentando os níveis de significância, coeficientes de determinação e análise de variância. O nível de significância avaliado foi de $5 \%(p=0,05)$. 


\subsection{RESULTADOS E DISCUSSÃO}

\subsubsection{Composição em ácidos graxos}

As composições em ácidos graxos da banha e do óleo de soja estão semelhantes aos valores citados na literatura (O' BRIEN, 1998; CODEX, 1999; DAVENEL et al., 1999; GLÄSER et al., 2004). A composição em ácidos graxos da banha depende de características como a raça, sexo e idade do animal. Além disso, a saturação da banha depende principalmente do tipo de alimentação que o animal recebe (O' BRIEN, 1998).

Os principais ácidos graxos na banha são o oléico, com $41 \%$ do total de ácidos graxos, seguido pelo palmítico (25\%), linoléico (13\%) e esteárico (13\%). Os ácidos graxos saturados da banha constituem cerca de $40 \%$ do total de ácidos graxos (Tabela 23).

A interesterificação não afeta o grau de saturação dos ácidos graxos e não causa isomeração. Nossos resultados demosntram que a interesterificação não causou alteração significativa no perfil de ácidos graxos das gorduras e suas misturas. 
Tabela 23. Composição em ácidos graxos da banha, óleo de soja e de suas misturas binárias antes e após a interesterificação.

\begin{tabular}{|c|c|c|c|c|c|c|c|c|c|c|}
\hline Ácido graxo & $\begin{array}{l}\text { Banha } \\
\text { (Antes) }\end{array}$ & $\begin{array}{l}\text { Banha } \\
\text { (Após) }\end{array}$ & $\begin{array}{l}\text { 80-20 } \\
\text { (Antes) }\end{array}$ & $\begin{array}{l}\text { 80-20 } \\
\text { (Após) }\end{array}$ & $\begin{array}{l}\text { 60-40 } \\
\text { (Antes) }\end{array}$ & $\begin{array}{l}\text { 60-40 } \\
\text { (Após) }\end{array}$ & $\begin{array}{l}\text { 50-50 } \\
\text { (Antes) }\end{array}$ & $\begin{array}{l}\text { 50-50 } \\
\text { (Após) }\end{array}$ & $\begin{array}{c}\text { Óleo soja } \\
\text { (Antes) }\end{array}$ & $\begin{array}{c}\text { Óleo soja } \\
\text { (Após) }\end{array}$ \\
\hline $16: 0$ & $25,4 \pm 0,19$ & $23,9 \pm 0,19$ & $23,0 \pm 0,07$ & $22,3 \pm 0,07$ & $19,3 \pm 0,00$ & $19,3 \pm 0,05$ & $20,5 \pm 0,01$ & $20,0 \pm 0,08$ & $12,1 \pm 0,01$ & $12,7 \pm 0,04$ \\
\hline $16: 1$ & $2,4 \pm 0,00$ & $2,4 \pm 0,02$ & $1,9 \pm 0,00$ & $1,6 \pm 0,00$ & $1,3 \pm 0,00$ & $1,2 \pm 0,02$ & $1,3 \pm 0,04$ & $1,2 \pm 0,02$ & - & - \\
\hline $18: 1 n-9$ cis & $41,4 \pm 0,01$ & $41,8 \pm 0,2$ & $37,0 \pm 0,02$ & $37,5 \pm 0,00$ & $32,8 \pm 0,00$ & $34,1 \pm 0,1$ & $30,5 \pm 0,02$ & $31,1 \pm 0,04$ & $22,1 \pm 0,03$ & $22,5 \pm 0,1$ \\
\hline $18: 1 n-9 t$ & $2,6 \pm 0,01$ & $2,5 \pm 0,02$ & $2,4 \pm 0,00$ & $2,0 \pm 0,11$ & $2,1 \pm 0,00$ & $2,4 \pm 0,05$ & $2,0 \pm 0,01$ & $2,1 \pm 0,00$ & $1,5 \pm 0,05$ & $1,5 \pm 0,05$ \\
\hline $18: 2 n-6$ & $13,4 \pm 0,00$ & $14,1 \pm 0,02$ & $21,5 \pm 0,04$ & $21,4 \pm 0,14$ & $31,1 \pm 0,00$ & $27,5 \pm 0,4$ & $33,5 \pm 0,03$ & $32,5 \pm 0,6$ & $55,6 \pm 0,02$ & $54,0 \pm 0,05$ \\
\hline
\end{tabular}




\subsubsection{Composição em triacilgliceróis}

A correta identificação e quantificação dos triacilgliceróis é necessária para o entendimento das propriedades físicas dos lipídios nos alimentos, como o conteúdo de gordura sólida e ponto de fusão (NEFF, 2002).

A composição dos triacilgliceróis das gorduras individuais e das misturas binárias antes e após a interesterificação enzimática é apresentada na Tabela 24.

Os principais triacilgliceróis presentes na banha foram: POO $(23,2 \%)$, seguido em ordem decrescente por PStO (18,3\%), PLL (12,2\%), POL (8,5\%), PPO $(7,8 \%)$ e PPL $(5,7 \%)$. Os resultados de composição em triacilgliceróis da banha foram similares aos descritos pela literatura (NEFF et al.,2002).

A banha interesterificada apresentou diminuição em PStO de 18,3 para $11,7 \%$, POO de 23,2 para $18,2 \%$, POL de 8,5 para $5,4 \%$ e PLL de 12,2 para $11,6 \%$. Por outro lado, os triacilgliceróis PPO, PPL e StStO tiveram seus teores diminuídos.

Os principais triacilgliceróis presentes no óleo de soja foram PLL (19,0\%), LLL (16,5\%), OLL (16,2\%), POL (13,9\%), OOL (12,1\%) e POO (6,4\%).

A composição em triacilgliceróis da banha, da banha interesterificada e de suas misturas com o óleo de soja antes e após a interesterificação foram divididas em quatro classes, baseadas no número de ácidos graxos saturados e insaturados (BESSLER \& ORTHOEFER, 1983; ZEITON et al., 1993; LIST et al., 1997). Estes resultados são apresentados na Figura 28.

A composição em triacilgliceróis da gordura é responsável por maior parte das propriedades físicas que afetam a aplicação do alimento, como fusão na boca e textura (BESSLER \& ORTHOEFER, 1983). 
Tabela 24. Composição em triacilgliceróis da banha, do óleo de soja e suas misturas binárias antes e após a interesterificação ( $P$, ácido palmítico; Po, ácido palmitoléico; M, ácido mirístico; St, ácido esteárico; $\mathrm{O}$, ácido oléico; L, ácido linoléico; Ln, ácido linolênico).

\begin{tabular}{|c|c|c|c|c|c|c|c|c|c|c|c|}
\hline $\begin{array}{l}\text { Número } \\
\text { de } \\
\text { Carbonos }\end{array}$ & $\mathrm{TAGs}^{\mathrm{a}}$ & $\begin{array}{c}\text { Banha } \\
\text { (Antes) }\end{array}$ & $\begin{array}{l}\text { Banha } \\
\text { (Após) }\end{array}$ & $\begin{array}{c}80-20 \\
\text { (Antes) }\end{array}$ & $\begin{array}{c}\text { 80-20 } \\
\text { (Após) }\end{array}$ & $\begin{array}{c}60-40 \\
\text { (Antes) }\end{array}$ & $\begin{array}{c}\text { 60-40 } \\
\text { (Após) }\end{array}$ & $\begin{array}{c}50-50 \\
\text { (Antes) }\end{array}$ & $\begin{array}{c}\text { 50-50 } \\
\text { (Após) }\end{array}$ & $\begin{array}{c}\text { Óleo de } \\
\text { soja } \\
\text { (Antes) }\end{array}$ & $\begin{array}{c}\text { Óleo de } \\
\text { soja } \\
\text { (Após) }\end{array}$ \\
\hline \multirow{3}{*}{48} & PPP & 0,6 & 1,9 & 0,5 & 1,7 & 0,4 & 1,4 & 0,3 & 1,6 & 0,0 & 0,0 \\
\hline & MPO & 1,4 & 2,0 & 1,1 & 1,5 & 0,8 & 1,0 & 0,7 & 1,1 & 0,0 & 0,0 \\
\hline & PPPo & 0,9 & 0,9 & 0,7 & 1,1 & 0,5 & 0,7 & 0,4 & 0,8 & 0,0 & 0,0 \\
\hline \multirow{5}{*}{50} & PPSt & 1,8 & 3,5 & 1,5 & 2,6 & 1.1 & 2,2 & 0,9 & 1,9 & 0,0 & 0,0 \\
\hline & PPO & 7,8 & 11,4 & 6,6 & 9,2 & 5,4 & 7,7 & 4,8 & 6,6 & 1,7 & 2,0 \\
\hline & PPL & 5,7 & 6,1 & 5,5 & 6,1 & 5,3 & 6,6 & 5,2 & 6,7 & 4,7 & 4,4 \\
\hline & MOL & 1,6 & 1,6 & 1,3 & 2,0 & 1,0 & 1,4 & 0,8 & 1,9 & 0,0 & 0,0 \\
\hline & MLL & 0,7 & 0,7 & 0,6 & 0,0 & 0,4 & 0,0 & 0,4 & 0,9 & 0,0 & 0,0 \\
\hline \multirow{8}{*}{52} & PStSt & 2,3 & 2,4 & 1,8 & 2,0 & 1,4 & 1,2 & 1,1 & 1,5 & 0,0 & 0,0 \\
\hline & PStO & 18,3 & 11,7 & 14,9 & 9,3 & 11,4 & 6,3 & 9,7 & 5,0 & 1,1 & 1,2 \\
\hline & $\mathrm{POO}$ & 23,2 & 18,2 & 19,8 & 14,6 & 16,5 & 9,9 & 14,8 & 13,3 & 6,4 & 4,9 \\
\hline & PLL & 12,2 & 11,6 & 13,6 & 14,8 & 14,9 & 17.4 & 15,6 & 16,8 & 19,0 & 16,8 \\
\hline & POL & 8,5 & 5,4 & 9,5 & 5,5 & 10,6 & 6,1 & 11,2 & 9,2 & 13,9 & 14,0 \\
\hline & PLnL & 0,0 & 0,0 & 0,5 & 0,0 & 0,0 & 0,0 & 0,5 & 0,0 & 2,6 & 2,7 \\
\hline & PLnLn & 0,0 & 0,0 & 0,2 & 0,2 & 1,1 & 0,0 & 0,9 & 0,0 & 1,0 & 0,9 \\
\hline & PoLL & 1,8 & 2,1 & 0,0 & 0,0 & 1,0 & 0,0 & 1,3 & 0,0 & 0,0 & 0,0 \\
\hline \multirow{10}{*}{54} & StStSt & 1,2 & 2,1 & 1,5 & 5,2 & 1,1 & 7,7 & 0,6 & 1,4 & 0,0 & 0,0 \\
\hline & StStO & 2,8 & 4,8 & 0,9 & 0,2 & 1,7 & 1,9 & 1,4 & 2,1 & 0,0 & 0,0 \\
\hline & StOL & 0,0 & 0,0 & 2,2 & 1,8 & 0,8 & 0,0 & 0.9 & 0,0 & 1,9 & 1,6 \\
\hline & StOO & 2,9 & 3,6 & 2,9 & 2,9 & 2,8 & 2,3 & 2,8 & 1,8 & 2,7 & 3,2 \\
\hline & 000 & 2,8 & 3,6 & 2,2 & 2,7 & 1,7 & 2,4 & 1,4 & 4,6 & 0,0 & 0,0 \\
\hline & OOL & 2,0 & 3,9 & 4.0 & 4,4 & 6,0 & 4,5 & 7,0 & 8,7 & 12,1 & 12,2 \\
\hline & OLL & 1,1 & 1,7 & 4,1 & 7,2 & 7,2 & 10,4 & 8,7 & 2,8 & 16,2 & 20,7 \\
\hline & LLL & 0,0 & 0,0 & 3,3 & 3,4 & 6,6 & 6,5 & 8,2 & 8,9 & 16,5 & 15,9 \\
\hline & LLLn & 0,0 & 0,0 & 0,0 & 1,1 & 0,0 & 2,4 & 0,1 & 3,4 & 0,1 & 0,4 \\
\hline & LnLnL & 0,0 & 0,0 & 0,0 & 0,2 & 0,0 & 0,0 & 0,1 & 0,0 & 0,1 & 0,4 \\
\hline
\end{tabular}

${ }^{a}$ A sigla do triacilglicerol não indica a localização dos ácidos graxos no triacilglicerol 



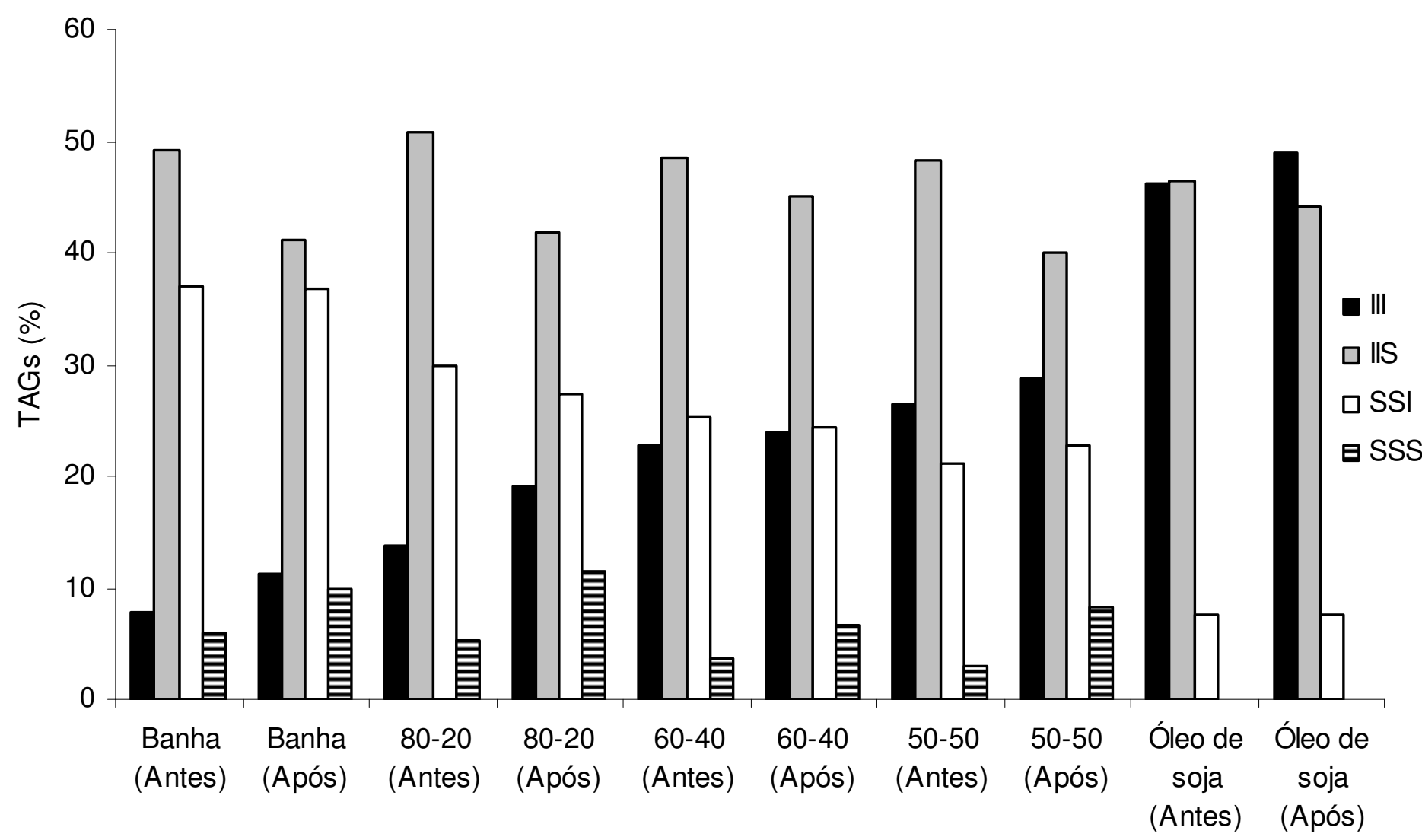

Figura 28. Perfil de TAGs da banha e suas mistura com o óleo de soja antes e após a interesterificação (Abreviações: SSS, trissaturados; SSI, dissaturados;

IIS, monossaturados;

e

III, triinsaturados). 

Nos triacilgliceróis, os ácidos graxos insaturados foram designados por I e os ácidos graxos saturados por $\mathrm{S}$, que foram divididos em quatro grupos. $\mathrm{O}$ primeiro grupo III tem ponto de fusão em torno de -13 a $1 \stackrel{\circ}{\circ}$. Este grupo promove a facilidade de manipulação dos lipídios, quando este é retirado diretamente do refrigerador. São comuns em óleos vegetais como o de soja, milho, algodão, amendoim e canola, que possuem cerca de $56-75 \%$ de triacilgliceróis deste grupo. Estes óleos permanecem liquídos à temperatura de $5^{\circ} \mathrm{C}$, comum em refrigeradores domésticos. $\mathrm{O}$ segundo grupo de triacilgliceróis consiste principalmente do tipo SII, que funde à temperatura de 6-23 $\stackrel{\circ}{ } \mathrm{C}$. Estes produtos apresentam adequada lubricidade a $25 \stackrel{\circ}{\circ} \mathrm{C}$. Os óleos vegetais possuem cerca de $21-37 \%$ deste grupo. Os óleos acima mencionados são de fácil manuseio nas temperaturas de 5 a $25 \stackrel{\circ}{\circ}$ devido às altas proporções de triacilgliceróis destes grupos.

As propriedades funcionais das margarinas, como o manuseio à temperatura ambiente e a temperatura de fusão na boca, são influenciadas principalmente pela presença dos triacilgliceróis dos grupos 3 e 4, que consistem em triacilgliceróis dissaturados e trissaturados, que fundem a $27-42^{\circ} \mathrm{C}$ e $56-65^{\circ} \mathrm{C}$, respectivamente. Pesquisas devem ser conduzidas para a melhoria na composição dos triacilgliceróis e estrututra de óleos vegetais (MOUNTS et al., 1988; LIU \& WHRITE, 1992; WILSON, 1993; SLABAS, SIMON \& ELBOROUGH, 1995) que poderão ser utilizados como matéria-prima para a indústria de alimentos (ZEITON et al., 1993; LIST et al., 1997).

A interesterificação da banha com o óleo de soja aumentou a quantidade de III e de SSS e reduziu a quantidade de triacilgliceróis IIS (Figura 28).

A banha contém aproximadamente $6 \%$ de trissaturados e $37 \%$ de dissaturados. Os principais trisaturados são PStSt (2,3\%), PPSt $(1,8 \%)$, StStSt $(1,2 \%)$ and PPP $(0,6 \%)$. Os principais dissaturados são PStO $(18,3 \%)$ and PPO $(7,8 \%)$. Quando a banha e suas misturas com o óleo de soja foram interesterificados, os totais de III e SSS aumentaram. As quantidades de IIS diminuíram em todas as gorduras após a interesterificação, indicando que ocorreram trocas dos ácidos graxos entre os triacilgliceróis. O aumento dos triacilgliceróis SSS das misturas entre banha e óleo de soja após a interesterificação enzimática com a lipase específica para as posições $s n-1,3$ pode ser explicado principalmente pela presença do ácido palmítico na posição $s n-2$ na banha e pela presença de ácidos graxos saturados nas posições sn-1,3 no óleo de soja. Sendo 
assim, após a interesterificação enzimática ocorrem mudanças nas proporções de SSS (Figure 28).

\subsubsection{Ponto de amolecimento}

As alterações na composição dos triacilgliceróis da gorduras interesterificadas também refletiram no ponto de amolecimento das misturas. Os pontos de amolecimento da banha e das misturas com o óleo de soja antes e após a interesterificação com a enzima Lipozyme TL IM são apresentados na Tabela 25. Estas gorduras apresentaram pontos de amolecimento que variaram de 32,2 a $19,9^{\circ} \mathrm{C}$.

Tabela 25. Pontos de amolecimento da banha e de suas misturas binárias com o óleo de soja antes e após a interesterificação enzimática.

\section{Ponto de amolecimento $\left({ }^{\circ} \mathrm{C}\right)$}

Banha:Óleo de soja Antes da interesterificação Após a interesterificação

\begin{tabular}{lcc}
\hline $100: 0$ & $31,8 \pm 0,7$ & $32,2 \pm 0,1$ \\
$80: 20$ & $29,3 \pm 0,3$ & $25,8 \pm 0,6$ \\
$60: 40$ & $27,3 \pm 0,2$ & $23,5 \pm 0,1$ \\
$50: 50$ & $25,4 \pm 0,1$ & $19,9 \pm 1,4$
\end{tabular}

Média dos valores de quarto replicatas \pm desvio padrão. 
As maiores reducões no ponto de amolecimento após a interesterificação enzimática foram de $5,5^{\circ} \mathrm{C}$, e ocorreram quando a proporção banha: óleo de soja foi de 50:50.

A banha apresentou ponto de amolecimento de $31,8 \stackrel{\circ}{ } \mathrm{C}$, valor este próximo ao descrito pelo CODEX ALIMENTARIUS (1999), que descreve ampla faixa de temperatura (28-40 ํㅡ). Após a interesterificação, o ponto de amolecimento da banha aumentou ligeiramente para $32,2 \stackrel{\circ}{\circ}$. Este efeito pode ser explicado pelo aumento dos grupos SSS+SSI de $42,9 \%$ para $46,7 \%$. A adição de óleo de soja à banha promoveu decréscimo no ponto de amolecimento, e isto se deve provavelmente à incorporação de ácidos graxos poliinsaturados presentes no óleo de soja, causando aumento dos grupos III e diminuição dos grupos SSS+SSI.

As misturas interesterificadas apresentaram menores valores de ponto de amolecimento quando comparadas com as misturas antes da interesterificação, embora tenha ocorrido aumento nos grupos SSS+SSI (Figura 28). Estes resultados estão de acordo com os apresentados anteriormente por outros pesquisadores que interesterificaram sebo bovino com óleo de canola utilizando como catalisador a lipase específica sn-1,3 (FORSSEL et al., 1992; KOWALSKI et al., 2004). Este decréscimo observado no ponto de amolecimento de todas misturas interesterificadas foi provavelmente causado pela mudança na estrutura dos triacilgliceróis. Devido às trocas dos ácidos graxos com e entre os triacilgliceróis, novos triacilgliceróis são formados e novas interrelações entre eles podem aparecer.

\subsubsection{Consistência}

A textura de "spreads" (margarinas ou cremes vegetais) é fator crítico na determinação da funcionalidade do produto e aceitabilidade pelo consumidor (WRIGHT et al., 2001).

A Figura 29 apresenta a consistência das amostras nas temperaturas de 10 a $25 \stackrel{\circ}{\circ}$. 


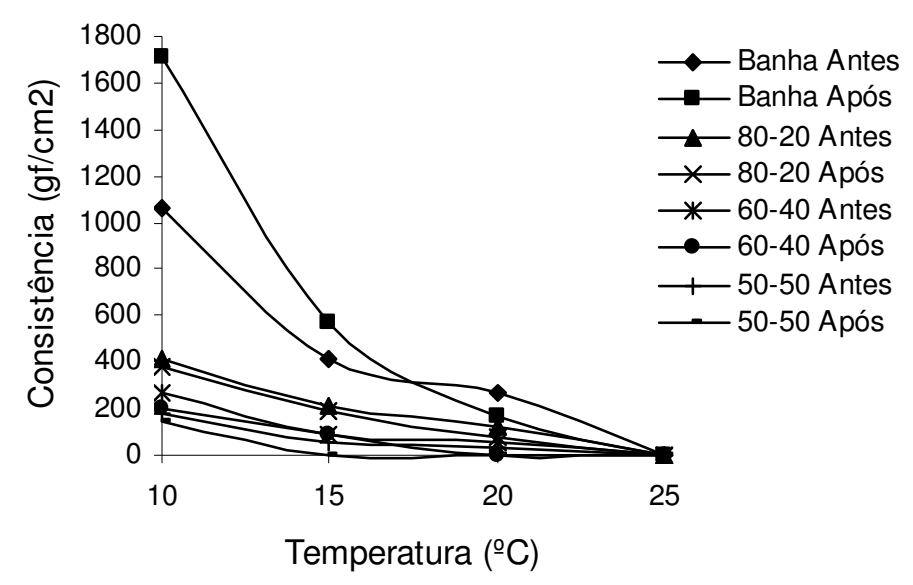

Figura 29. Consistência da banha e de suas misturas binárias com o óleo de soja antes e após a interesterificação enzimática..

A consistência decresce em função do aumento de temperatura e isto se deve à fusão gradual dos cristais, enfraquecendo a rede cristalina (ROUSSEAU, HILL, \& MARANGONI, 1996), que é responsável pela plasticidade de gorduras.

Nenhuma das amostras analisadas apresentou consistência a $30{ }^{\circ} \mathrm{C}$. O valor zero para consistência representa fisicamente produto com muito baixa consistência, que o equipamento analítico não é capaz de detectar. Estes produtos se apresentam geralmente na forma de fluido muito viscoso.

A tendência de cristalização (polimorfismo e morfologia) da banha interesterificada foi substancialmente diferente da banha nativa. Diferenças na tendência de cristlização e do comportamento de agregação levam a alteração na estrutura da rede cristalina da banha, resultando em propriedades reológicas diferentes como a consistência (MARANGONI \& ROSSEAU, 1998).

A consistência das misturas de banha e óleo de soja interesterificadas foi menor que das misturas não interesterificadas em todas as temperatures. Isto se deve provavelmente ao aumento das proporções de III após a interesterificação enzimática.

\subsubsection{Conteúdo de gordura sólida}

O conteúdo de gordura sólida das gorduras originais e das misturas antes e após a interesterificação é apresentado na Figura 30. A alteração na composição de triacilgliceróis da banha e de suas misturas após a interesterificação também refletiu 
no conteúdo de gordura sólida nas temperaturas de 10-35ํ․ Um aumento no conteúdo de gordura sólida $10 \stackrel{\circ}{ } \mathrm{C}$ foi detectado após a interesterificação, assim como ocorreu na consistência.

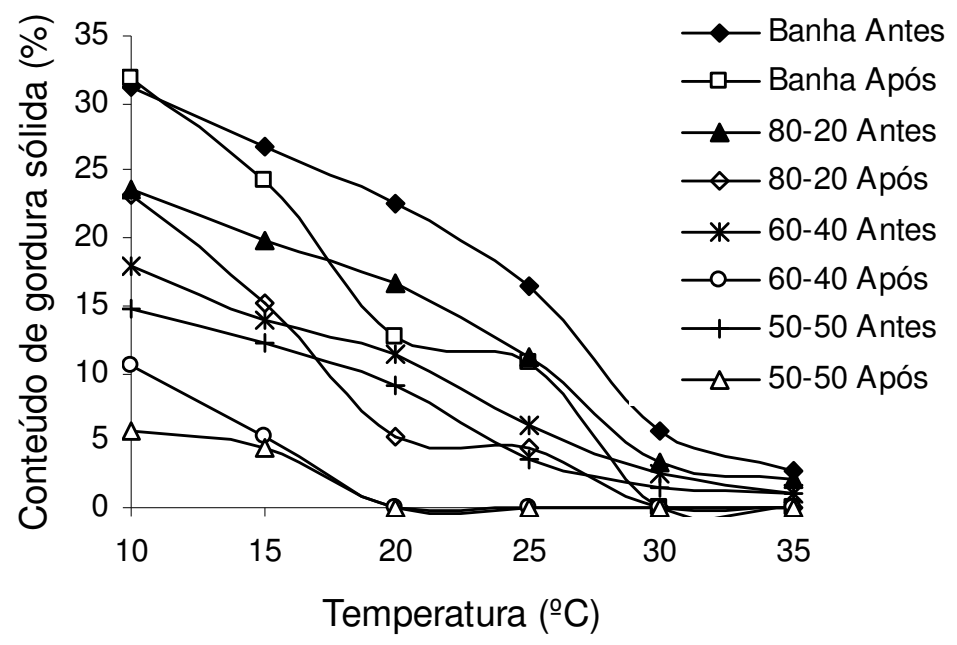

Figura 30. Conteúdo de gordura sólida da banha e suas misturas binárias com o óleo de soja antes e após a interesterificação enzimática.

Pode-se observar que, devido ao fato do óleo de soja ser um óleo líquido, a sua adição à banha causou forte decréscimo no conteúdo de gordura sólida. MARANGONI \& ROUSSEAU (1998) encontraram o mesmo comportamento para misturas entre banha e óleo de canola. De acordo com a literatura (MARANGONI \& ROUSSEAU, 1998; DAVENEL et al., 1999), a banha apresenta conteúdo de gordura sólida de $20 \%$ a $25 \stackrel{\circ}{\circ}$, próximo ao encontrado nesta pesquisa. As misturas entre banha e óleo de soja foram também afetadas pela interesterificação enzimática catalisada pela lipase. Estas mudanças no conteúdo de gordura sólida se devem provavelmente ao aumento de triacilgliceróis do grupo III após a reação.

\subsubsection{Microscopia}

A Figura 31 apresenta as imagens digitalizadas das amostras cristalizadas a 15ㄷ․ Nesta temperatura a adição de óleo de soja não causou diferenças morforlógicas na estrutura cristalina da banha. A banha e suas misturas com o óleo de soja apresentaram estrutura granular similar, composta por grande número de pequenos cristais (CAMPOS, NARINE \& MARANGONI, 2002). 


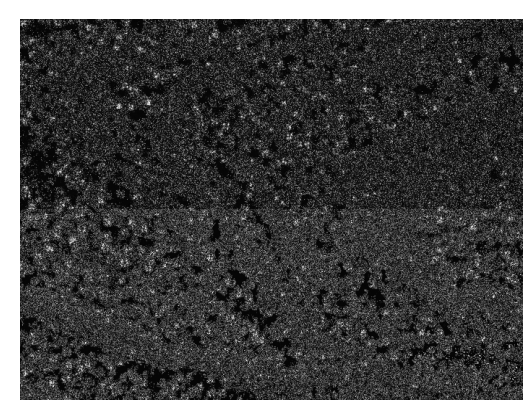

Banha

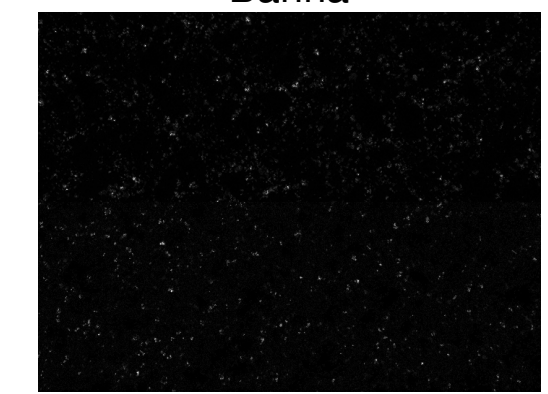

$80 \%$ Banha $+20 \%$ óleo de soja

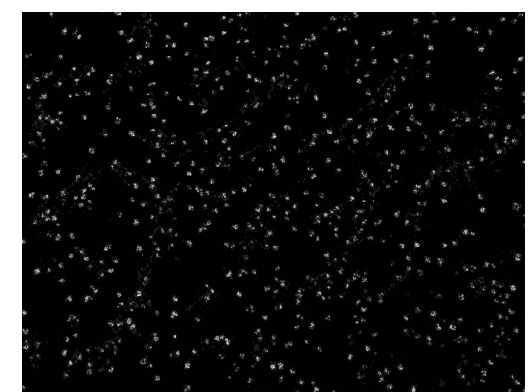

$60 \%$ Banha $+40 \%$ óleo de soja

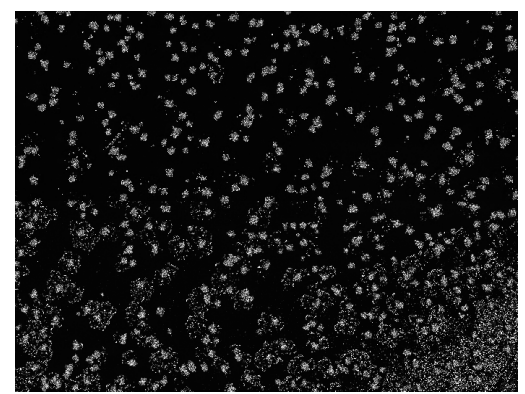

$50 \%$ Banha $+50 \%$ óleo de soja

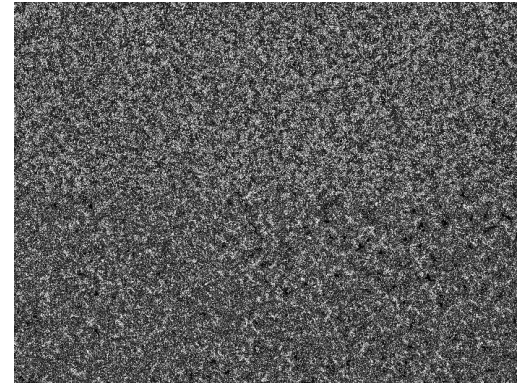

Banha após a interesterificação

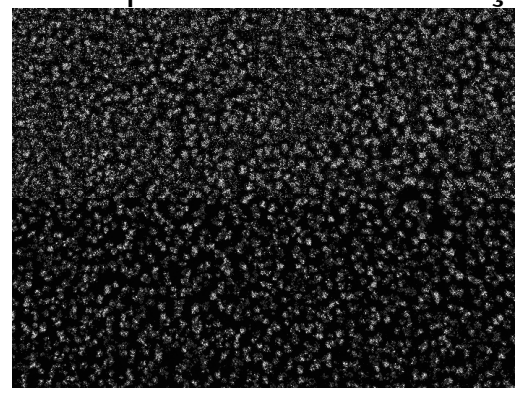

$80 \%$ Banha $+20 \%$ óleo de soja após a interesterificação

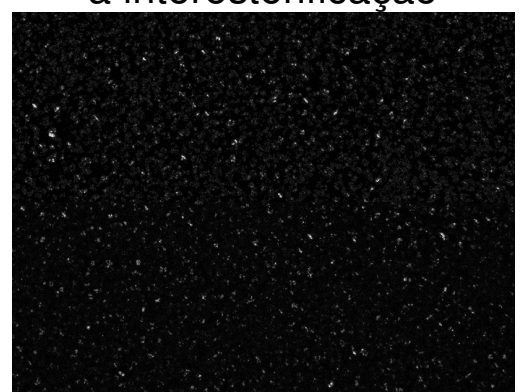

$60 \%$ Banha + 40\% óleo de soja após a interesterificação

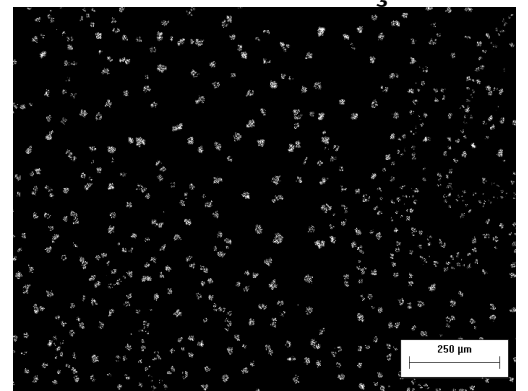

$50 \%$ Banha $+50 \%$ óleo de soja após a interesterificação

Figura 31. Imagens digitalizadas da rede cristalina a $15^{\circ} \mathrm{C}$ da banha e suas misturas binárias com o óleo de soja. A barra branca representa $250 \mu \mathrm{m}$. 
Assim como ocorreu com as propriedades físicas, como ponto de amolecimento, consistência e conteúdo de gordura sólida, após a interesterificação enzimática também puderam ser observadas diferenças na estrutura cristalina na microscopia sob luz polarizada.

A área cristalizada aumentou quando a banha e suas misturas com o óleo de soja foram interesterificadas (Figura 32). Este comportamento pode ser explicado pelo aumento dos triacilgliceróis SSS+SSI, que tem alto ponto de fusão.

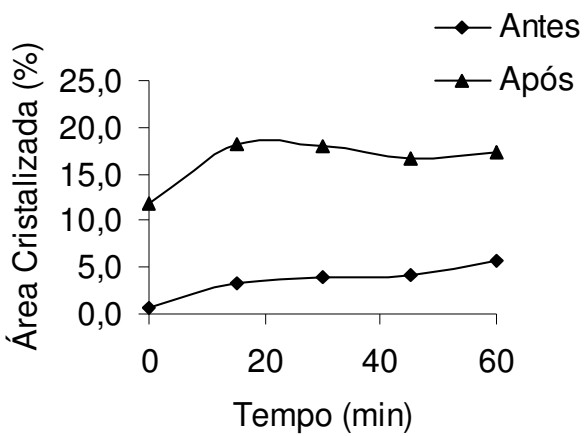

Banha - 15ㄷ

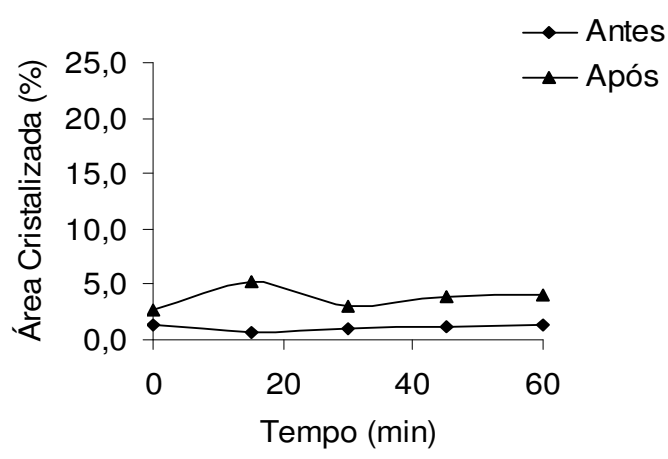

$60: 40-15 \div C$

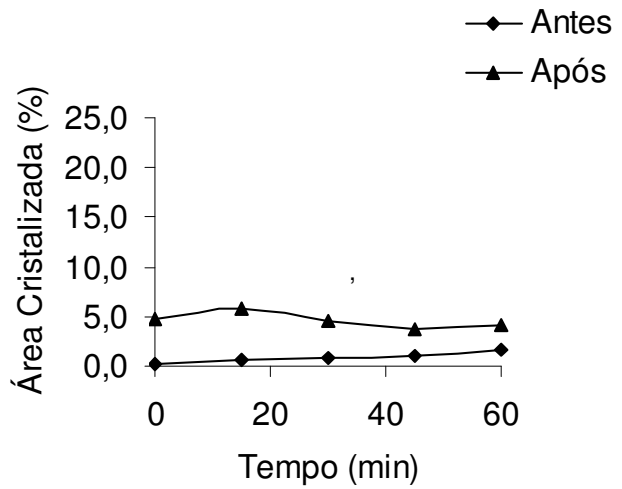

$80: 20-15 \div C$

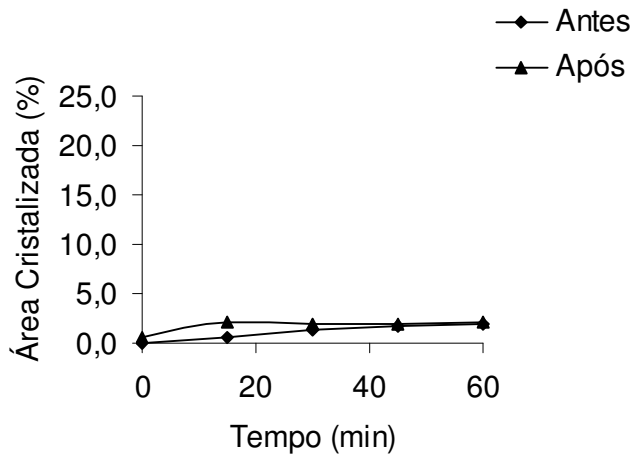

$50: 50-15 C$

Figura 32. Área cristalizada da banha e de suas misturas binárias com o óleo de soja antes e após a interesterificação enzimática. 


\subsubsection{Análise estatítica}

A análise estatística revelou que as propriedades de conteúdo de gordura sólida, ponto de amolecimento e consistência não foram dependentes do óleo de soja ( $p>0,05)$, mas foram dependentes da banha e da interação entre as duas gorduras $(p<0,05)$. Os coeficientes da interação $\beta_{12}$ sempre foram negativos, demonstrando interação monotética entre a banha e o óleo de soja. As amostras interesterificadas demonstraram o mesmo comportamento. 


\subsection{CONCLUSÕES}

A interesterificação produziu novos triacilgliceróis que mudaram as propriedades fisico-químicas das gorduras estudadas. A interesterificação das misturas entre banha e óleo de soja aumentou os triacilgliceróis dos grupos III e SSS e reduziu as quantidades de IIS. As misturas de banha e óleo de soja demonstraram ser alternativas viáveis para a produção de sucedâneos da gordura do leite humano. 


\subsection{REFERÊNCIAS BIBLIOGRÁFICAS}

AKOH, C.C. Structured lipids. In Food Lipids Chemistry,Nutrition, and Biology, 2nd ed.; Akoh, C. C., Min, D. B., Eds.; Dekker: New York, 2002; pp 877-908.

AOCS (1997a). Official method Ce 1-62: fatty acid composition by gas chromatography. Official methods and recommended practices of the American Oil Chemists' Society.

AOCS (1997b). Official method Cc 3-25: softening point. Official methods and recommended practices of the American Oil Chemists' Society.

AOCS (1999). Official method Cd 16b-93: solid fat content. Official methods and recommended practices of the American Oil Chemists' Society.

BESSLER, T.R.; ORTHOEFER, F.T. Providing lubricity in food fat systems. Journal of American Oil Chemists Society, v.60, p.1765-1768, 1983.

CAMPOS, R.; NARINE, S.S.; MARANGONI, A.G. Effect of cooling rate on the structure and mechanical properties of milk fat and lard. Food Research International, v.35, p. 971-981, 2002.

CHANG, M.K.; ABRAHAM, G.; JOHN, V.T. Production of cocoa butter-like fat from interesterification of vegetable oils. Journal of the American Oil Chemists Society. v. 67, p.832-834, 1990

CHAPPEL, J.E.; CLANDININ, M.T.; KEARNY-VOLPE, C.; REICHMAN, B.; SWYER, P.W. Fatty acid balance studies in premature infants fed human milk or formula: effect of calcium supplementation. Journal of Pediatrics. v.108, p.439-447, 1986.

CODEX ALIMENTARIUS. (1999). Codex. Standard for Named Animal Fats - CODEX - STAN 211 [internet document] URL http://www.codexalimentarius.net/search/advancedsearch.do. Accessed 02/08/2007. 
DAVENEL, A.; RIAUBLANC, A.; MARCHAL, P.; GANDEMER, G. Quality of pig adipose tissue: relationship between solid fat content and lipid composition. Meat Science, v.51, p.73-79, 1999.

FILLER, L.J.; MATTSON, F.; FOMON, S.J. Triglyceride configuration and fat absorption by the human infant. Journal of Nutrition. v.99, p.293- 298, 1969.

FORMUSO, L.B.; AKOH, C.C. Lipase-catalyzed acidolysis of olive oil and caprylic acid in a bench-scale packed bed bioreactor. Food Research International. v.35, p.15-21, 2002.

FORSSEL, P.; KERVINEN, R.; LAPPI, M.; LINKO, P.; SUORTTI, T.; POUTANEN, K. Effect of enzymatic interesterification on the melting point of tallow rapeseed oil (LEAR) mixture. Journal of the American Oil Chemists Society, v. 69, p.126-129, 1992.

GHAZALI, H.M.; HAMIDAH, S., CHE MAN, Y. B. Enzymatic transesterification of palm olein with nonspecific and 1,3-specific lipases. Journal of the American Oil Chemists Society, v.72, p.633-639, 1995.

GLÄSER, K.R.; WENK, C.; SCHEEDER, R.L. Evaluation of pork backfat firmmes and lard consistency using several different physicochemical methods. Journal of Science Food and Agriculture, v. 84, p.853-862, 2004.

HAIGHTON, A. J. The measurement of the hardness of margarine and fats with cone penetrometers. Journal of the American Oil Chemists' Society., v.36, p.345-348, 1959

HAMAM, F.; SHAHIDI, F. Enzymatic incorporation of capric acid into a single cell oil rich in docosahexaenoic acid and docosapentaenoic acid and oxidative stability of the resultant structured lipid. Food Chemistry. v.91, p.583-591, 2005.

HARTMAN, L.; LAGO, R.C.A. Rapid preparation of fatty acid methyl esters from lipids. Laboratory Practices, 22, 475-494. 1973

JENSEN, R.G. INfant formulas. In Structured and Modified Lipids; Gunstone, F. D., Ed.; Dekker: New York, 2001; pp 455-464. 
KENNEDY, K.; FEWTRELL, M.S.; MORLEY, R.; ABBOTT, R.; QUILAN, P.T.; WELLS, J.C.K.; BINDELS, J.G.; LUCAS, A. Double-blind, randomized trial of a synthetic triacylglycerol in formula-fed term infants: effects on stool biochemistry, stool characteristics, and bone mineralization. American Journal of Clinical Nutrition. v. 70, p. 920-927, 1999.

KOWALSKI, B.; TARNOWSKA, K.; GRUCZYNSKA, E.; BEKAS, W. Chemical and enzymatic interesterification of a beef tallow and rapeseed oil equal-weight blend. European Journal of Lipid Science and Technology. v. 106, p.655-664, 2004.

LIEN, E.L. The role of fatty acid composition and positional distribution in fat absorption in infants. Journal of Pedriatrics., 125, 562-568, 1994.

LIEN, E.L.; BOYLE, F.G.; YUHAS, R.; TOMARELLI, R.M.; QUINLAN, P. The effect of triglyceride positional distribution on fatty acid absorption in rats. Journal of Pediatric Gastroenterology and Nutrition. v.25, p.167-174, 1997.

LIST, G.R.; MOUNTS, T.L.; ORTHOEFER, F.; NEFF, W.E. Effect of interesterification on the structure and physical properties of high-stearic acid soybean oils. Journal of American Oil Chemists Society. v.74, p.327-329, 1997.

LIU, H.R.; WHITE, P.J. Oxidative stability of soybean oils with altered fatty acid compositions. Journal of American Oil Chemists Society. v.69, p.528-532, 1992.

LUCAS, A.; QUINLAN, P.; ABRAMS, S.; RYAN, S.; MEAH, S.; LUCAS, P.J. Randomized controlled trial of a synthetic triglyceride milk formula for preterm infant. Archives of Disease in Childhood, v.77, n.3, p.F178-F184, 1997.

MADUKO, C.O.; AKOH, C.C.; PARK, Y.W. Enzymatic interesterification of Tripalmitin with Vegetable Oil Blends for formulation of Caprine Milk Infant Formula Analogs. Journal of Dairy Science, v.90, n.4, p.594-601, 2007.

MADUKO, C.O.; AKOH, C.C.; PARK, Y.W. Production of Infant Milk Fat Analogs Containing Palmitic Acid: Optimization of Reactions by Response Surface Methodology. Journal of Dairy Science. v.90, n.7, p.2147-2150, 2007. 
MARANGONI, A.G.; ROUSSEAU, D., 1995. Engineering triacylglycerols: the role of interesterification. Trends in Food Science and Technology. v.6, pp. 329-335.

MARANGONI, A.G.; ROUSSEAU, D. Chemical and enzymatic modification of butterfat and butterfat-canola oil blends. Food Research International, v.31, n.8, p.595-599. 1998

MOUNTS, T.L.; WARNER, K.; LIST, G.R.; KLEIMAN, R.; FEHR, W. R.; HAMMOND, E.G; ANDWILCOX, J.R. Effect of altered fatty acid composition on soybean oil stability. Journal of American Oil Chemists Society. v.65, n.5, p.624-628, 1988.

MUKHERJEE, K.D.; KIEWITT, I. Structured triacylglycerols resembling human milk fat by transesterification catalyzed by papaya (Carcia papaya) latex. Biotechnology Letters. v.20, n.7, p.613-616, 1998.

NEFF, W.E.; BYRDWELL, W.C.; STEIDELEY, K.R.; LIST,G.R.; Snowder, G. Triacylglycerol structure of animal tallows, potential food formulation fats, by high performance liquid chromatography coupled with mass spectrometry. Journal of Liquid Chromatography \& Related Technologies. v.25, n.6, p.985-998, 2002

NIELSEN, N.S.; YANG, T.; XU, X.; JACOBSEN, C. Production and oxidative stability of a human milk fat substitute produced from lard by enzyme technology in a pilot packed-bed reactor. Food Chemistry. v.94, n.1, p.53-60, 2006

O'BRIEN, R. D. FATS AND OILS - Formulating and processing for applications. Basel: Technomic, 1998. p. 7-10, 33-36, 98-108,

ROUSSEAU, D.; HILL, A.R.; MARANGONI, A.G. Restructuring butterfat through blending and chemical interesterication. 3. Rheology. Journal of American Oil Chemists' Society. v.73, n.9, p.983- 989, 1996.

SAHIN, N.; AKOH, C.C.; KARAALI, A. Lipase-catalyzed acidolysis of tripalmitin with hazelnut oil fatty acids and stearic acid to produce human milk fat subsititute. Journal of Agricultural and Food Chemistry, v.53, n.14, 5779-5783, 2005.

SLABAS, A.R.; SIMON, J.W. ELBOROUGH, K.M. Information needed to create new oil crops. INFORM, v.6, n.1, p.159-166, 1995. 
SRIVASTAVA, A.; AKOH, C.C.; CHANG, S.W.; LEE, G.C.; SHAW, J.F. Candida rugosa lipase lip1-catalyzed transesterification to produce human milk fat substitute. Journal of Agricultural and Food Chemistry. v.54, n.14, p.5175 -5181, 2006.

THOMSON, A.B.; KEELAN, M.; GARG, M.L.; CLANDININ, M.T. Intestinal aspects of lipid absorption: a review. Canadian Journal of Physiology and Pharmacology, v.67, n.3, p.179-191, 1989.

WILLIS, W.M.; MARANGONI, A.G. Assessment of lipase- and chemically catalyzed lipid modification strategies for the production of structured lipids. Journal of American Oil Chemists Society. v.76, n.4, p.443-450, 1999

WILLIS, W.M.; LENCKI, R.W.; MARANGONI, A.G. Lipid modification strategies in the production of nutritionally functional fats and oils. Critical Reviews in Food Science and Nutrition. v.38, n.8, p.639-674, 1998.

WILSON, R.F. Practical biotechnological strategies for improving the quality and value of soybeans. INFORM, v.6, n.1, p.193-200,1993.

WRIGHT, A.J.; HARTEL, R.W.; NARINE, S.S.; MARANGONI, A.G. The effect of minor components on milk fat crystallization. Journal of American Oil Chemists Society. v.77, n.5, p.463-475, 2000.

XU, X.; SKANDS, A.R.H.; HOY, C.E.; MU, H.; BALCHEN, S.; NISSEN, J.A. Production of specific-structured lipids by enzymatic interesterification: elucidation of acyl migration by response surface design. Journal of American Oil Chemists Society. v.75, n.9, p.1179-1185, 1998.

$\mathrm{XU}, \mathrm{X}$; FOMUSO, L.B.; AKOH, C.C. Synthesis of structured triacylglycerols by lipase-catalyzed acidolysis in a packed bed bioreactor. Journal of Agricultural and Food Chemistry, v.48, n.1, p.3-10, 2000.

ZEITOUN, M.A.M.; NEFF, W.E.; LIST, G.R.; MOUNTS, T.L. Physical properties of interesterified fat blends. Journal of American Oil Chemists Society. v.70, n.4, p.467-471,1993. 
YAMANE, T. Enzyme technology of lipid industry: an engineering overview. Journal of American Oil Chemists Society. v.64, n.12, p. 1657-1662, 1987. 


\section{CONSIDERAÇÕES FINAIS}

Dentre as misturas, as que continham $80 \%$ banha e $20 \%$ óleo de soja e $60 \%$ banha e $40 \%$ óleo de soja foram as que mais se aproximaram da composição em ácidos graxos da gordura do leite humano.

O Betapol e a gordura do leite humano apresentam quantidades muitos semelhantes de ácido palmítico na posição sn-2, entretanto diferenças na composição de ácidos graxos produzem lipídios com propriedades físicas totalmente distintas.

A interesterificação química alterou a distribuição dos triacilgliceróis nas gorduras, apresentando acréscimo de di e trissaturados. Estes aumentos foram refletidos nas propriedades físicas. Apenas as mistura que continham 40 e $50 \%$ de óleo de soja apresentavam ponto de fusão próximo à gordura do leite humano.

A interesterificação enzimática catalisada pela lipase Lipozyme TL IM, demonstra ser a mais interessante das alternativas dentre os catalisadores estudados. Devido a sua especificidade para a posição sn-1,3 permite maior controle reacional, podendo ser utilizada para produzir lipídios específicos como sucedâneos da gordura do leite humano.

Considerando os resultados de propriedades físicas e químicas dos lipídios produzidos, a mistura contendo $60 \%$ banha e $40 \%$ óleo de soja interesterificada pela lipase Lipozyme TL IM, apresentou sendo a mais promissora para a utilização como sucedêneo da gordura do leite humano. 
ANEXOS 


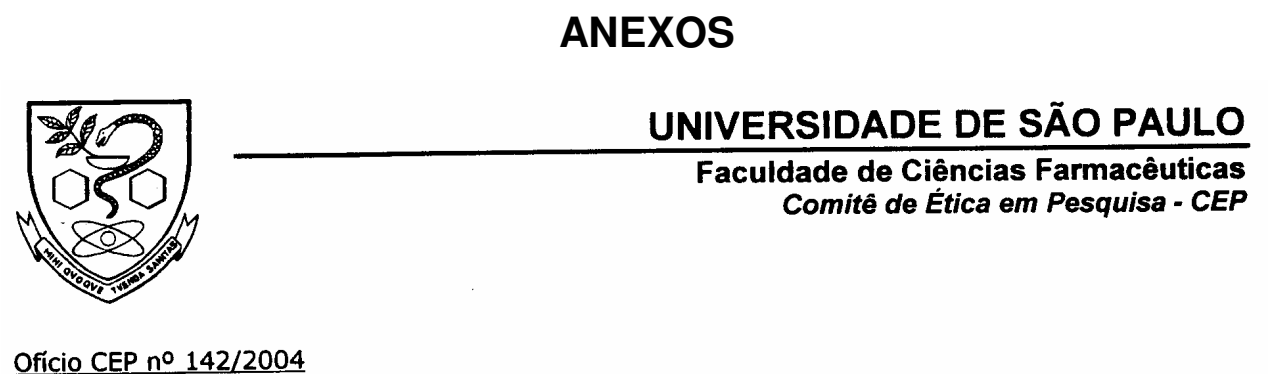

São Paulo, 07 de dezembro de 2004.

$\operatorname{Ilmo}(\mathbf{a}) . \operatorname{Sr}(\mathbf{a})$.

Roberta Claro da Silva

Vimos informar que o Comitê de Ética em Pesquisa da FCF/USP, em reunião realizada em 06 de dezembro p.p., APROVOU o projeto "Síntese de lipídios estruturados por interesterificação de banha e óleo de soja para obtenção de um sucedâneo da gordura do leite humano" (Protocolo ${ }^{\circ} 285$ ) apresentado por Vossa Senhoria.

Lembramos que após a execução de $50 \%$ do cronograma do projeto, deverá ser apresentado um relatório parcial, de acordo com o Artigo 18 - item C, da Portaria FCF$111 / 97$.

Atenciosamente,

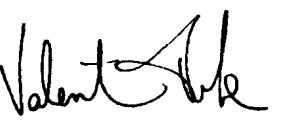

Prof ${ }^{\mathrm{a}}$. Dr $\mathbf{r}^{\mathrm{a}}$. Valentina Porta

Coordenadora do Comitê de Ética

em Pesquisa da FCF/USP

Orientador: Prof. Luiz Antonio Gioiẹlli

FBT

Av. Prof. Lineu Prestes, $\mathrm{n}^{\circ}$ 580, Bloco 13 A - Cidade Universitária - CEP 05508-900 - Săo Paulo - SP Fone: (11) 3091-3677 - Fax (11) 3031-8986 - e-mail: cepfcf@usp.br 
São Paulo, 5 de novembro de 2004.

$I^{\text {mo(a) }} \cdot S^{\text {r(a) }}$

\section{Prof. Dr. Luiz Antonio Gioielli}

Departamento de Tecnologia Bioquímico-Farmacêuticas

Área de Tecnologia de Alimentos da Faculdade de Ciências Farmacêutica

UNIVERSIDADE DE SÃO PAULO

REFERENTE: Projeto de Pesquisa "Síntese de lipídios estruturados por interesterificação de banha e óleo de soja para obtenção de sucedâneo da gordura do leite humano" - Registro CEP: 455/04

Prezado(a) Senhor(a)

O Comitê de Ética em Pesquisa do Hospital Universitário da Universidade de São Paulo, em reunião ordinária de 5 de novembro de 2004, analisou o projeto de pesquisa acima citado, considerando-o como APROVADO, bem como seu Termo de Consentimento Livre e Esclarecido.

Lembramos que cabe ao pesquisador elaborar e apresentar a este Comitê, relatórios anuais (parciais ou final, em função da duração da pesquisa), de acordo com a Resolução do Conselho Nacional de Saúde 196 de 10-10-1996, item VII.13.d.. O primeiro relatório está previsto para 5 de novembro de 2005.

Atenciosamente,

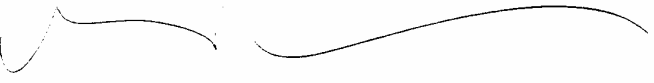

Dr. Maurício Seckler

Vice-Coordenador

Comitê de Ética em Pesquisa - CEP

HOSPITAL UNIVERSITÁRIO DA UNIVERSIDADE DE SÃO PAULO COMITÊ DE ÉTICA EM PESQUISA - CEP 

